\title{
Workshop Report: Measurement Techniques in Highly Transient, Spectrally Rich Combustion Environments
}

\section{Todd E. Rosenberger}

\section{ARL-SR-18}

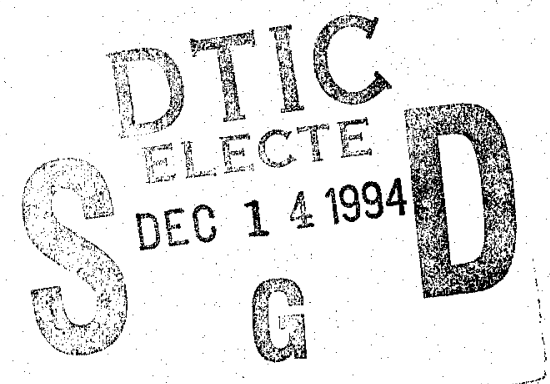

APPROVED FOR PUBLIC RELEASE; DISTRIBUTION IS UNLIMTIED.

\section{8}




\section{NOTICES}

Destroy this report when it is no longer needed. DO NOT return it to the originator.

Additional copies of this report may be obtained from the National Technical Information Service, U.S. Department of Commerce, 5285 Port Royal Road, Springfield, VA 22161.

The findings of this report are not to be construed as an official Department of the Army position, unless so designated by other authorized documents.

The use of trade names or manufacturers' names in this report does not constitute indorsement of any commercial product. 


\begin{tabular}{|c|c|c|}
\hline \multicolumn{2}{|c|}{ REPORT DOCUMENTATION PAGE } & $\begin{array}{l}\text { Form Approved } \\
\text { OMB No. 0704-0188 }\end{array}$ \\
\hline \multicolumn{3}{|c|}{ 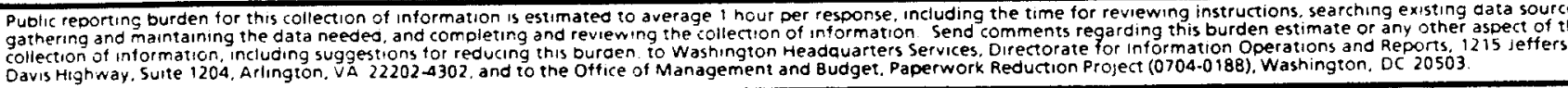 } \\
\hline 1. AGENCY USE ONLY (Leave blank) & $\begin{array}{l}\text { 2. REPORT DATE } \\
\text { September } 1994\end{array}$ & $\begin{array}{l}\text { 3. REPORT TYPE AND DATES COVERED } \\
\text { Final, 1-30 November } 1993\end{array}$ \\
\hline \multicolumn{2}{|c|}{$\begin{array}{l}\text { 4. TITLE AND SUBTITLE } \\
\text { Workshop Report: Measurement Techniques in Highly Transient, Spectrally } \\
\text { Rich Combustion Environments }\end{array}$} & 5. FUNDING NUMBERS \\
\hline \multicolumn{3}{|l|}{$\begin{array}{l}\text { 6. AUTHOR(S) } \\
\text { Todd E. Rosenberger }\end{array}$} \\
\hline $\begin{array}{l}\text { 7. PERFORMING ORGANIZATION NAN } \\
\text { U.S. Army Research Laborato } \\
\text { ATTN: AMSRL-WT-PA } \\
\text { Aberdeen Proving Ground, M }\end{array}$ & $\begin{array}{l}\text { (S) AND ADDRESS(ES) } \\
21005-5066\end{array}$ & $\begin{array}{l}\text { 8. PERFORMING ORGANIZATION } \\
\text { REPORT NUMBER }\end{array}$ \\
\hline $\begin{array}{l}\text { 9. SPONSORING / MONITORING AGEN } \\
\text { U.S. Army Research Laborato } \\
\text { ATTN: AMSRL-OP-AP-L } \\
\text { Aberdeen Proving Ground, M }\end{array}$ & $\begin{array}{l}\text { NAME(S) AND ADDRESS(ES) } \\
21005-5066\end{array}$ & $\begin{array}{l}\text { 10. SPONSORING/MONITORING } \\
\text { AGENCY REPORT NUMBER } \\
\text { ARL-SR-18 }\end{array}$ \\
\hline \multicolumn{3}{|l|}{ 11. SUPPLEMENTARY NOTES } \\
\hline $\begin{array}{l}\text { 12a. DISTRIBUTION / AVAILABILITY ST } \\
\text { Approved for public release; }\end{array}$ & $\begin{array}{l}\text { TEMENT } \\
\text { stribution is unlimited. }\end{array}$ & 12b. DISTRIBUTION CODE \\
\hline
\end{tabular}

13. ABSTRACT (Maximum 200 words)

With the emergence of advanced propulsion systems such as liquid propellant (LP), electrothermal-chemical (ETC), electromagnetic (EM), conventional hypervelocity, and in-bore ramjet, the measurement of combustion phenomena has become more complex. The data associated with these systems can be rich in high-frequency components, and share similar transient behavior. Measurement techniques associated with conventional solid propellant systems are not always capable of accurately recording these phenomena.

The accuracy of pressure and acceleration measurements in combustion chambers, barrels, and on-board projectiles has been compromised by the lack of a fundamental understanding of the effects of the mounting configuration and the mechanical and electrical components of the transducer on the integrity of the measurement. Consequently, the system development and technical understanding of the physical processes involved in the ignition and combustion of such advanced propulsion systems have been compromised. A workshop was needed to bring logether experts from the aforementioned and related communities to disseminate knowledge of lessons leamed and to discuss the techniques necessary to make high-fidelity pressure measurements in these environments.

This report will state the objectives, identify the participants who met to address them, provide a list of the technical presentations made, present highlights from these presentations and the discussions that they prompted, and end with conclusions and recommendations which came out of the workshop.

14. SUBJECT TERMS

measurement tochniques, highly transient, spectrally rich, combustion environments, pressure measurement, high-frequency combustion characterization, pressure oscillations, liquid propellants, in-bore ramjet, RLPGs

\begin{tabular}{|c|c|c|}
\hline $\begin{array}{l}\text { 17. SECURITY CLASSIFICATION } \\
\text { OF REPORT } \\
\text { UNCI A SCIEIFD }\end{array}$ & $\begin{array}{l}\text { 18. SECURITY CLASSIFICATION } \\
\text { OF THIS PAGE }\end{array}$ & $\begin{array}{l}\text { 19. SECURITY CLASSIFICATION } \\
\text { OF ABSTRACT }\end{array}$ \\
\hline UNCLASSIFIED & UNCLASSIFIED & UNCLASSIFIED \\
\hline
\end{tabular}

\begin{tabular}{|l|}
$\begin{array}{l}\text { 15. NUMBER OF PAGES } \\
178\end{array}$ \\
$\begin{array}{l}\text { 16. PRICE CODE } \\
\text { 20. LIMITATION OF ABSTRACT } \\
\text { SAR }\end{array}$ \\
\hline
\end{tabular}


INTENTIONALLY LEFT BLANK. 


\section{ACKNOWLEDGMENTS}

The author wishes to thank all the participants, especially the presenters, for their contributions to a successful workshop. The author and the participants in the workshop also wish to express their gratitude to the Chemical Propulsion Information Agency (CPIA) and the JANNAF Combustion Subcommittee for sponsoring this workshop.

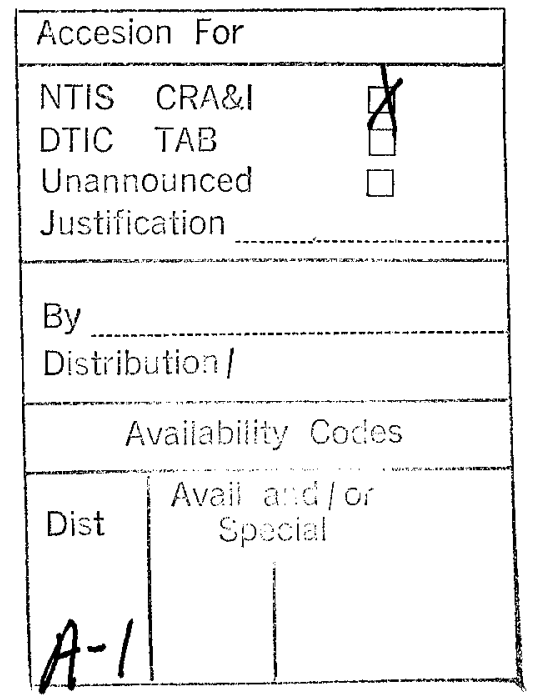


INTENTIONALLY LEFT BLANK. 
ACKNOWLEDGMENTS $\ldots \ldots \ldots \ldots \ldots \ldots \ldots \ldots \ldots \ldots \ldots \ldots$ iii

LIST OF FIGURES $\ldots \ldots \ldots \ldots \ldots \ldots \ldots \ldots \ldots \ldots \ldots \ldots \ldots \ldots \ldots$ vii

1. INTRODUCTION $\ldots \ldots \ldots \ldots \ldots \ldots \ldots \ldots \ldots \ldots \ldots \ldots \ldots \ldots \ldots \ldots$

2. WORKSHOP OBJECTIVES $\ldots \ldots \ldots \ldots \ldots \ldots \ldots \ldots \ldots \ldots \ldots \ldots \ldots$

3. WORKSHOP PARTICIPANTS $\ldots \ldots \ldots \ldots \ldots \ldots \ldots \ldots \ldots \ldots \ldots \ldots \ldots$

4. LIST OF PRESENTATIONS $\ldots \ldots \ldots \ldots \ldots \ldots \ldots \ldots \ldots \ldots \ldots \ldots \ldots$

5. HIGHLIGHTS FROM PRESENTATIONS AND DISCUSSION $\ldots \ldots \ldots \ldots$

5.1 Oscillatory Pressure Measurements in High-Frequency Environments $\ldots \ldots \ldots 7$

$5.2 \quad$ Alternate Pressure Transducers $\ldots \ldots \ldots \ldots \ldots \ldots \ldots \ldots \ldots \ldots \ldots \ldots \ldots \ldots$

S.3 Alternate Pressure Measurement Techniques $\ldots \ldots \ldots \ldots \ldots \ldots \ldots$

6. CONCLUSIONS AND RECOMMENDATIONS $\ldots \ldots \ldots \ldots \ldots \ldots \ldots \ldots \ldots$

7. REFERENCES $\ldots \ldots \ldots \ldots \ldots \ldots \ldots \ldots \ldots \ldots \ldots \ldots \ldots \ldots \ldots \ldots$

APPENDIX A: PRESENTATION - "MEASUREMENT TECHNIQUES IN HIGHLY TRANSIENT, SPECTRALLY RICH COMBUSTION ENVIRONMENTS: WELCOME, WORKSHOP MOTIVATION AND OBJECTIVES"

APPENDIX B: PRESENTATION - "COMPARISON OF PRESSURE MEASUREMENTS IN THROUGH PORTS AND STEPPED PORTS"

APPENDIX C: PRESENTATION - "MEASUREMENT OF OSCILLATORY PRESSURE USING SINGLE DIAMETER AND TWO DIAMETER TRANSDUCER CAVITIES" $\ldots \ldots \ldots \ldots \ldots \ldots \ldots \ldots$

APPENDIX D: PRESENTATION - "FURTHER EVIDENCE OF THE EFFECTS OF TWO DIAMETER TRANSDUCER CAVITIES ON PRESSURE MEASUREMENTS" . . . . . . . . . . . . . . .

APPENDIX E: PRESENTATION - "HIGH FREQUENCY PRESSURE OSCILLATIONS IN THE IN BORE RAMJET ACCELERATOR" .

APPENDIX F: PRESENTATION - "AN OPTICAL PRESSURE GAUGE FOR HIGH SPEED MEASUREMENTS IN THE 10-250 KBAR RANGE" . . . 
APPENDIX G: PRESENTATION - "PRESSURE TRANSDUCERS FOR THE

LIQUID PROPELLANT GUN" . . . . . . . . . . . . . . 149

APPENDIX H: PRESENTATION - "FIBER OPTIC PRESSURE

TRANSDUCERS" $\ldots \ldots \ldots \ldots \ldots \ldots \ldots \ldots \ldots \ldots \ldots \ldots$

DISTRIBUTION LIST $\ldots \ldots \ldots \ldots \ldots \ldots \ldots \ldots \ldots \ldots \ldots \ldots \ldots \ldots \ldots \ldots \ldots$ 


\section{LIST OF FIGURES}

Figure $\quad$ Page

1. Examples of highly transient, spectrally rich pressure-time data $\ldots \ldots \ldots \ldots$

2. Block diagram of a typical measurement system $\ldots \ldots \ldots \ldots \ldots \ldots \ldots \ldots$

3. Typical procedure for analyzing both the quasi-steady-state and oscillatory components of a spectrally rich combustion pressure $\ldots \ldots \ldots \ldots \ldots \ldots \ldots \ldots$

4. Steady-state pressure response spectrum for a two-diameter gauge cavity $\ldots \ldots \ldots$

5. (a) A two-diameter gauge cavity and (b) an expression for the first natural frequency

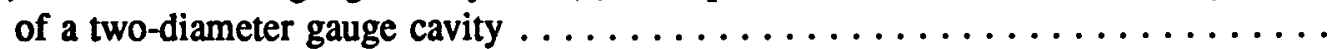

6. Procedure for measuring both quasi-steady-state and oscillatory components of a

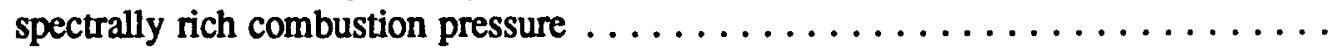


INTENTIONALLY LEFT BLANK. 


\section{INTRODUCTION}

With the emergence of advanced propulsion systems such as liquid propellant (LP), electrothermalchemical (ETC), electromagnetic (EM), conventional hypervelocity, and in-bore ramjet, the measurement of combustion phenomena has become more complex. The data associated with these systems can be rich in high-frequency components, and share similar transient behavior. Measurement techniques associated with conventional solid propellant systems are not always capable of accurately recording these phenomena.

The accuracy of measurements, specifically of pressure and acceleration phenomena in combustion chambers, barrels, and on-board projectiles has been compromised by the lack of a fundamental understanding of the effects of the physical configuration and the mechanical and electrical components on the integrity of the measurement. Current combustion chamber, gun tube, and on-board projectile measurements needed to characterize system response to these highly transient, spectrally rich combustion environments may be inadequate for modelers to characterize the theoretical response of system hardware to these harsh environments.

Consequently, the development and technical understanding of the physical processes involved in the ignition and combustion of such advanced propulsion systems have been compromised. Although the propulsion system examples noted are primarily in the gun arena, it is hoped that the expertise that exists in the rocket and ramjet communities may be brought to bear on this problem. A workshop was needed to bring together experts from the aforementioned and related communities to disseminate knowledge of lessons learned and to discuss the techniques necessary to make high-fidelity pressure measurements in these environments.

The request for a workshop examining measurement techniques in highly transient, spectrally rich combustion environments was submitted at the $29^{\text {th }}$ JANNAF Combustion Subcommittee Meeting and later approved by the Executive Committee. The workshop was held 19 November 1993 at the Hyatt Regency Hotel, Monterey, CA under the auspices of the $30^{\text {th }}$ JANNAF Combustion Subcommittee Meeting and was chaired by the author of this workshop report. This report will state the objectives, identify the participants who met to address them, provide a list of the technical presentations made, present highlights from these presentations and the discussion that they prompted, and end with conclusions and recommendations which came out of the workshop. 


\section{WORKSHOP OBJECTIVES}

The workshop objectives were distributed to the participants in the call for papers and attendees for the workshop. The specific workshop objectives were the following:

- Outline the measurement challenges and problems associated with characterizing combustion environments in solid propellant (SP), LP, ETC, EM, conventional hypervelocity, in-bore ramjet, and associated technologies

- Survey measurement techniques appropriate for the measurement of highly transient, spectrally rich combustion phenomena in guns, simulators, and on-board projectiles of propulsion technologies including, but not limited to: SP, LP, ETC, EM, conventional hypervelocity and in-bore ramjet

- Recommend future measurement technology research areas.

\section{WORKSHOP PARTICIPANTS}

The general goal of the workshop was to assemble expert attendees, drawn from gun, rocket, ramjet, and related disciplines and representing government, industry, and academia, that would disseminate knowledge of lessons leamed to the various communities represented and discuss the techniques necessary to make high-fidelity pressure measurements in these highly transient, spectrally rich combustion environments. The workshop call for papers and attendees was mailed to a large number of prospective attendees from the relevant disciplines. While representatives from the desired areas were in attendance, a wider representation from those areas probably would have added significant contributions to the workshop. The workshop attendees were:

\author{
G. A. Benedetti, \\ Sandia National Laboratory (SNL) \\ Steven Brown, \\ Martin Marietta \\ Mary Chan, \\ Naval Air Weapons Center (NAWC)
}

\author{
David Kruczynski, \\ U.S. Army Research Laboratory (ARL)
}

G. L. Mackenzie, Stone Engineering

John Mandzy, Martin Marietta 
Kok Chung,

Army Research, Development,

and Engineering Center (ARDEC)

Arthur Cohen,

ARL

Marilyn Cooper,

PCB Piezotronics

James DeSpirito,

ARL

Jerry Finlinson,

NAWC

Robert Greig,

GT-Devices

Albert Horst,

ARL

B. L. Iwanciow, Stone Engineering

Gary Katulka, ARL

Roderick King,

ARDEC

John Knapton, ARL
Neale Messina, Princeton Combustion Research Laboratory (PCRL)

Thomas Minor,

ARL

Michael Nusca,

ARL

Welton "Red" Phillips, Yuma Proving Ground (YPG)

Fredrick Robbins, ARL

Todd Rosenberger, ARL

Gabiel Roy, Office of Naval Research (ONR)

Ray Rychnovski, SNL

Mark Schneider, FMC

Neale Winsor, GT-Devices

Jody Wormhoudt, Aerodyne

\section{LIST OF PRESENTATIONS}

Eight papers were presented over the duration of the 4-hr workshop with time at the end of each presentation for questions and discussion. The workshop concluded with a 30 -min period during which the participants attempted to come to some conclusions, or at least a consensus, on the major issues which were discussed throughout the session. In addition, this time was used to make recommendations for future measurement technology research investigations. Copies of the viewgraphs used in the workshop presentations are included in the appendices. The presentations were: 
"Measurement Techniques in Highly Transient, Spectrally Rich Combustion Environments: Welcome, Workshop Motivation and Objectives," T. E. Rosenberger, ARL.

"Comparison of Pressure Measurements in Through Ports and Stepped Ports," R. E. Rychnovsky, Sandia National Laboratories (SNL).

"Measurement of Oscillatory Pressure Using Single Diameter and Two Diameter Transducer Cavities," G. A. Benedetti, SNL.

"Further Evidence of the Effects of Two Diameter Transducer Cavities on Pressure Measurements," J. DeSpirito, N. E. Boyer, T. E. Rosenberger, and J. W. Colburn, ARL.

"High Frequency Pressure Oscillations in the In Bore Ramjet Accelerator," D. L. Kruczynski and J. W. Colburn, ARL.

"An Optical Pressure Gauge For High Speed Measurements in the 10-250 kbar Range," J. Wormhoudt, P. L. Kebabian, and K. D. Annen, Aerodyne Research, Inc.

"Pressure Transducers for the Liquid Propellant Gun," Welton "Red" Phillips, Yuma Proving Ground (YPG).

"Fiber Optic Pressure Transducers," T. E. Rosenberger, ARL, for W. S. Walton, U.S. Army Combat Systems Test Activity (CSTA).

"Recommendations for Future Measurement Technology Research," Workshop Participants.

\section{HIGHLIGHTS FROM PRESENTATIONS AND DISCUSSION}

In beginning the workshop, the motivation and objectives outlined earlier in this report were presented by the workshop chairman, T. E. Rosenberger of ARL. He reminded the participants that the agenda for the workshop was directed mainly toward the measurement of combustion pressure in transient, highfrequency environments because the response to the call for papers resulted almost exclusively in presentations in this arena. Consequently, the decision was made to concentrate on this area of measurement technology. 
Rosenberger began the presentation by pointing out that the combustion environment of conventional guns is traditionally characterized by relatively low frequency $(<10 \mathrm{kHz})$ data. On the other hand, the combustion environments of advanced propulsion systems such as regenerative liquid propellant guns (RLPGs), hybrid in-bore ramjets (HIRAMs), and early ETC guns using LP as the fuel, were characterized by transient, high-frequency (near-DC to $80 \mathrm{kHz}$ ) data. Examples of pressure-time (p-t) data for these systems are shown in Figure 1.

One of the most pertinent questions that one must ask of the data is whether they are an accurate description of the physical processes involved. During the past several years, questions have been raised concerning the adequacy of the measurement techniques used to quantify the combustion environments in these advanced propulsion systems. A general consensus throughout the measurement community is that some of the measurement techniques used to characterize traditional propulsion systems are inadequate for characterizing the "highly transient, spectrally rich combustion environments" associated with emerging propulsion technologies.

Figure 2 shows a block diagram of a typical measurement system. It consists of a transducer, mounting configuration, signal conditioning equipment, acquisition system, and associated instrumentation lines. One can associate a number of measurement challenges/problems with each area of the measurement system, though only a handful of the most pressing issues were presented here.

Rosenberger pointed out that vendor specifications for transducers were well above the requirements for conventional testing. Subsequently, parameters such a resonant frequency, acceleration, shock, and vibration sensitivity were not found to be a limitation for measurements like pressure and acceleration. However, as the frequency content of the data became higher and the environment more severe, the limits of the transducers were pushed, often beyond their capabilities. Consequently, vendor specifications like those mentioned must always be examined closely to determine the applicability of the transducer to the environment. It was pointed out that pressure transducers used in these environments have demonstrated a mortality rate much higher than those used in conventional testing. It was postulated that since the combustion gas temperatures are typically the same as those experienced in conventional testing, the cause of this phenomenon can be directly linked to excessive gauge vibration in the presence of the severe, highfrequency oscillations. 
Regenerative Liquid Propellant Gun
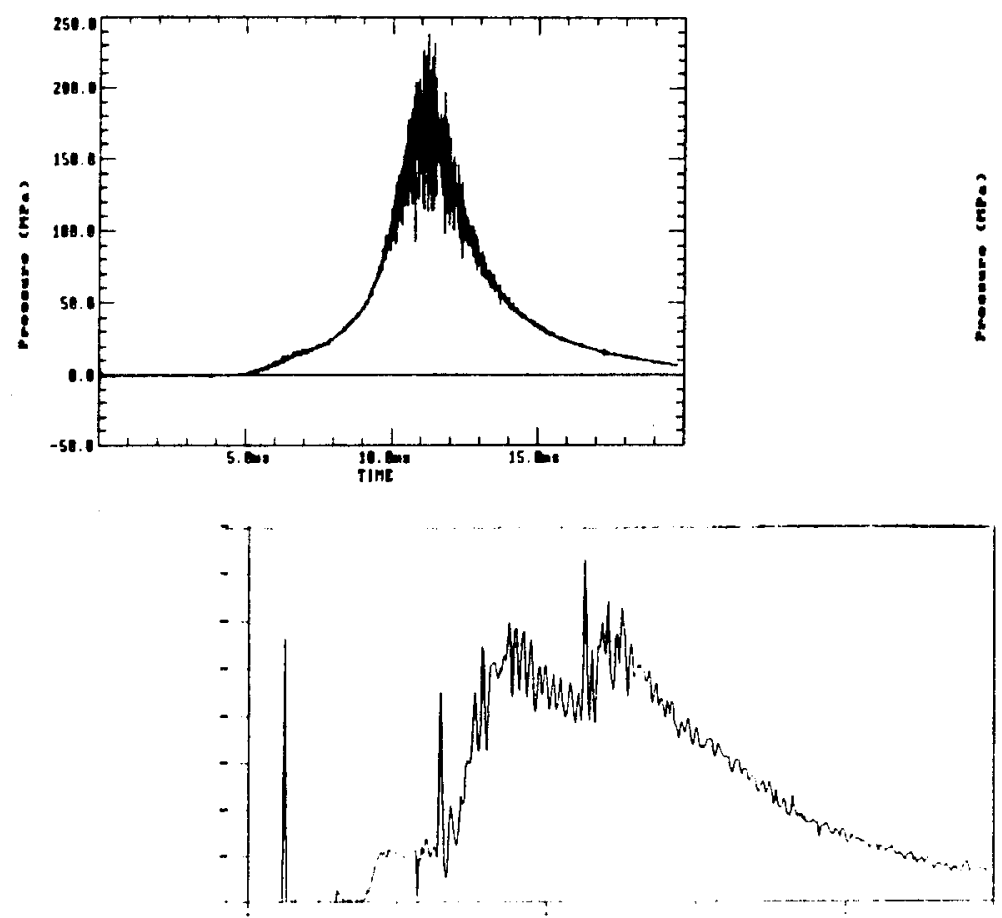

Figure 1. Examples of highly transient, spectrally rich pressure-time data.

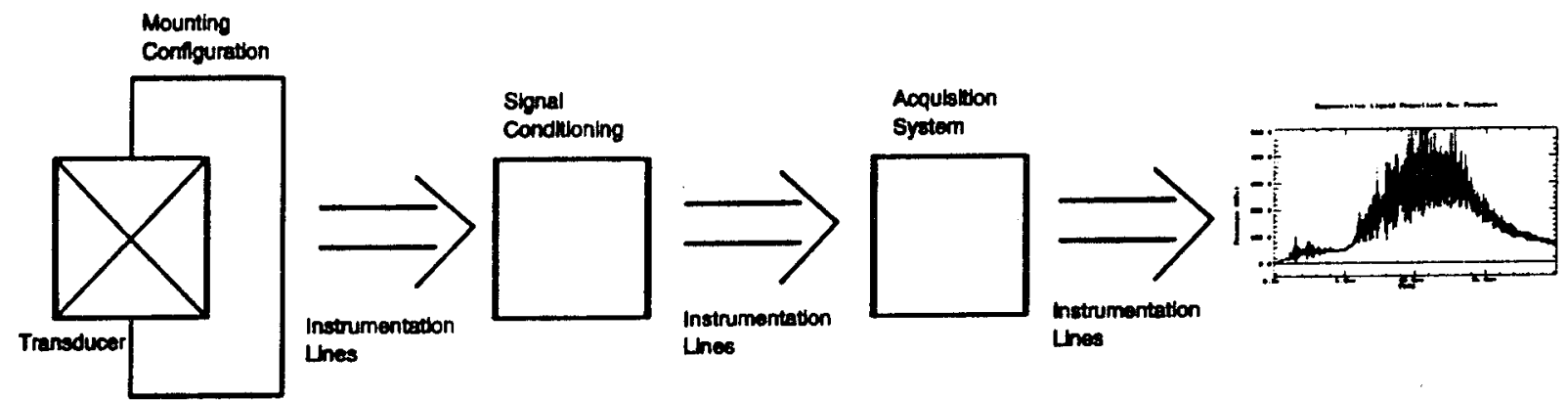

Figure 2. Block diagram of a typical measurement system. 
The mounting configuration used in implementing the transducer can also play a major role in the validity of the high-frequency measurement. The configuration of traditional two-diameter gauge port cavities, typically filled with grease to protect the transducer from thermal effects, has a major impact on the frequency response of the measurement. It is not known at this time the full extent that gauge port filling materials have on the measurement. The effects of silicone grease and RTV have not been fully investigated.

Other phenomena such as barrel pressure data showing high-frequency oscillations before passage of the projectile, and subsequent exposure to combustion pressure, lead investigators to believe that the gauges are ringing in the high-frequency environment. The difficulty with this is that if the barrel gauge shows a level of oscillations due to gauge vibration phenomena, the question naturally arises as to what contribution this has to the total amplitude of oscillations measured in the combustion chamber or projectile base. Gauges mounted at the end of the muzzle in large-caliber weapons, or used in highvelocity firings, often tend to be destroyed due to a dynamic flexural wave traveling down the tube. In both instances mentioned, it would be advantageous to develop a vibration-insensitive mounting technique to allow meaningful characterization of the combustion environment.

Finally, problems associated with a lack of proper signal conditioning were discussed. A phenomenon known as aliasing was reviewed, which, if not properly accounted for, can severely bias the frequency response of the measurement. Data were recorded with and without an anti-aliasing filter to demonstrate the effects of not filtering the data correctly. The data presented clearly demonstrated the importance of proper signal conditioning in accurately resolving frequencies over the range of interest.

Rosenberger summarized by stating that the measurement techniques used in these highly transient, spectrally rich combustion environments were in need of further review. Consequently this workshop was organized to examine measurement challenges and attempt to gain a community consensus on solutions for making high-fidelity pressure measurements in these environments.

5.1 Oscillatory Pressure Measurements in High-Frequency Environments. It is very important to note here that pressure measurements in high-frequency applications such as RLPGs actually consist of two components; the quasi-steady-state, or mean pressure, and the oscillatory pressure. Figure 3 represents a typical procedure for analyzing these data. The upper left is a plot of raw p-t data. The upper right is a plot of the quasi-steady-state (mean pressure) portion of the data, which is arrived at by performing a 

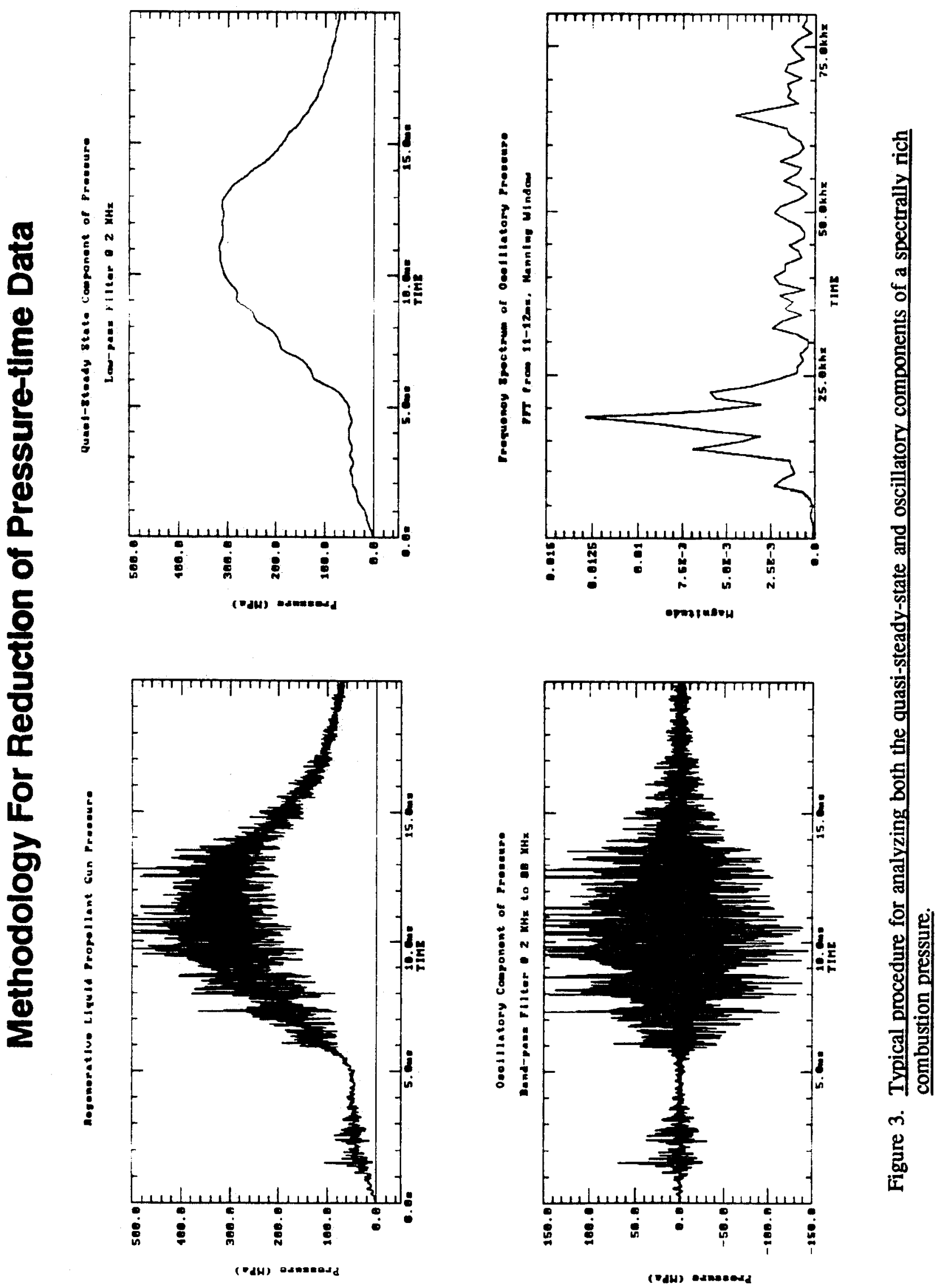
low-pass filtering operation at about $2 \mathrm{kHz}$ to remove the high-frequency component. The lower left is a plot of the oscillatory portion of the data which is obtained by performing a band-pass filtering operation between $2 \mathrm{kHz}$ and $80 \mathrm{kHz}$ to remove the quasi-steady-state component. Finally, the lower right is a magnitude vs. frequency plot of the Fast Fourier Transform (FFT) for the oscillatory portion of the data. This frequency spectrum can then be compared to those of pressure measurements at other locations to gain insight as to both the amplitude and energy contained in the oscillatory portion of the p-t data.

To date, most investigators have made use of the standard two-diameter gauge port mounting configuration, filled with grease for thermal protection, in an effort to characterize both the quasi-steadystate portion as well as the oscillatory portion of the combustion pressure. Typically data are taken at several radial locations within a single longitudinal position in an attempt to more accurately characterize the combustion process of the RLPG. Analysis of these data has demonstrated good agreement in the quasi-steady-state portion of the p-t data, but showed considerable variation in terms of the amplitude and frequency response of the oscillatory portion of the data. As it tums out, the data were severely limited in their frequency response due to the configuration of the measurement system.

Data from the SNL liquid injector/combustor were presented by R. Rychnovski as an example of this phenomenon. These data consisted of five pressure measurements in a single longitudinal plane (P31-P35) which measured the same quasi-steady-state pressure, but which exhibited considerably different amplitude and frequency components of the oscillatory pressure. When several of the ports were modified and configured as single-diameter through ports, the large variation in both amplitude and frequency response was eliminated between the data taken with the single-diameter ports.

Dr. G. A. Benedetti of SNL offered both a theoretical and an experimental explanation of this phenomenon. In order to make a good measurement, the system requires a flat response $\left(P_{\text {oul }} / P_{\text {in }}=1\right)$ over the range of frequencies of interest associated with the input signal. This implies that the natural frequency of the gauge port cavity and transducer must be significantly higher than the highest frequency of interest in the input signal (i.e., $f_{\text {nat cavity }} \geq 5 f_{\text {input signal }}$ ). The steady-state pressure response spectrum for a two-diameter gauge cavity is shown in Figure 4.

$\omega$ is the frequency of pressure oscillation at the gun tube wall, and $\omega_{\mathrm{n}}$ is the first undamped natural circular frequency for the cavity. As one can see, at about $20 \%$ of the resonant frequency, the magnitude of $P_{\text {out }} / P_{\text {in }}$ begins to be amplified. At frequencies above $20 \%$ and near the resonant frequency, the input 
signal will be severely amplified. At frequencies significantly higher than the natural frequency, the input signal will be severely attenuated. As one would expect, this would have a very profound effect on the quality of the data if the resonant frequency of the transducer cavity is low with respect to the range of input frequencies of interest.

An acoustical analysis of the cavity results in the expression for the first natural frequency for the transducer cavity, shown in Figure 5.

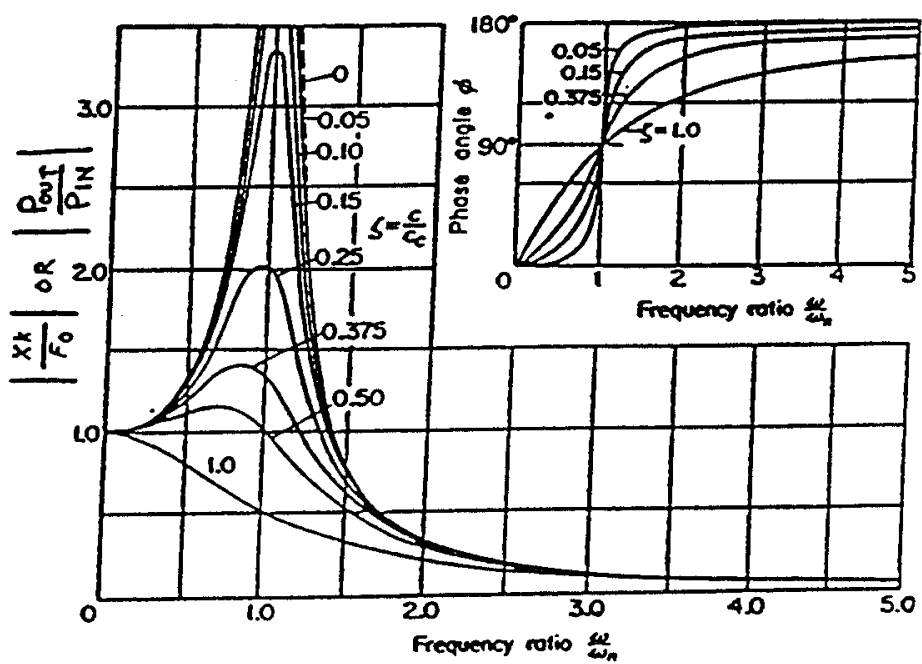

Figure 4. Steady-state pressure response spectrum for a two-diameter gauge cavity.

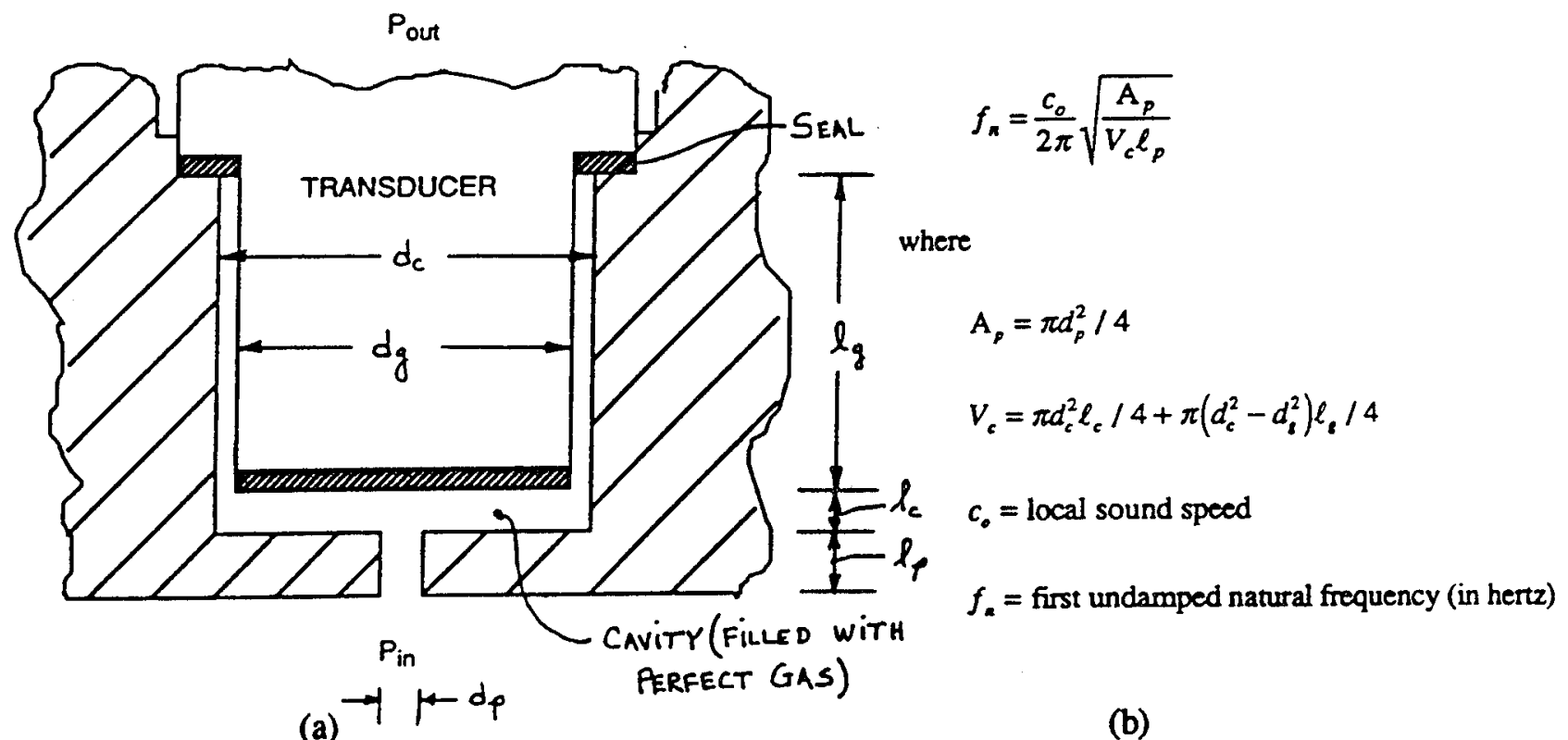

Figure 5. (a) A two-diameter gauge cavity and (b) an expression for the first natural frequency of a two-diameter gauge cavity. 
The gauge cavity resonant frequency of typical two-diameter gauge ports which are within specification range from $30-40 \mathrm{kHz}$. It is important to note that the cavity dimensions can vary due to tolerances, machining errors, and installation procedures. If one assumes cavity-resonant frequencies of $30-40 \mathrm{kHz}$, then the data acquired using these ports are "flat" to only $6-8 \mathrm{kHz}$. At frequencies above $6-8 \mathrm{kHz}$, the data will be biased significantly. Benedetti presented data from acoustic measurements which support the theoretical analysis outlined above. In addition, a comparison of nonacoustical data acquired in the SNL liquid injector/combustor was presented which also supported this assertion (Benedetti 1993).

James DeSpirito of the ARL presented data taken in an RLPG which also supported the assertion made above. Results showed that both two-diameter and single-diameter gauge port cavities without grease follow the acoustical analysis. In addition, the two-diameter cavity limits the frequency response of the measurement to a few kilohertz. Perhaps equally important, the effects of the use of silicone grease in the two-diameter ports were studied. It was found that when silicone grease was used in the twodiameter port, the data did not follow the acoustical analysis. The reason for this is because the grease that is initially packed in the gauge cavity is not present after testing. At some point during the interior ballistic cycle, the grease is removed from the cavity and the local sound speed in the cavity changes. Consequently the acoustic analysis does not hold.

To demonstrate that the measurement of high-frequency pressure oscillations was not unique to the RLPG community, Mr. David Kruczynski of the ARL gave an overview of pressure measurements taken in the $120-\mathrm{mm}$ in-bore ramjet accelerator. He showed that the combustion environment in this propulsion concept is much like that of the RLPG. Pressure measurements taken with two-diameter gauge port configurations were shown to severely limit the frequency response of the data when compared to those of single-diameter gauge ports.

Based upon the data acquired at SNL and supported by studies at the ARL, Benedetti put forward a procedure for characterizing both the quasi-steady-state and the oscillatory portions of the p-t data. The procedure is outlined in Figure 6.

It was the consensus of the workshop participants that this procedure would greatly improve the characterization of the oscillatory portion of the combustion environment. In most cases, the quasi-steadystate portion of the measurement is of primary interest. However, when the effects of the high-frequency 


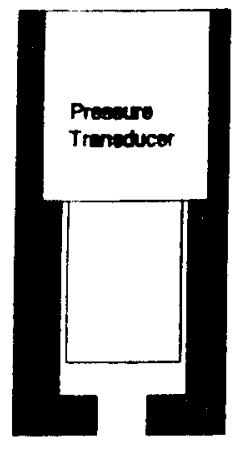

Two-diameter port

- Quasi-steady-state

-0.090" offset

- Mechanically stable

gage

- Grease for thermal

protection

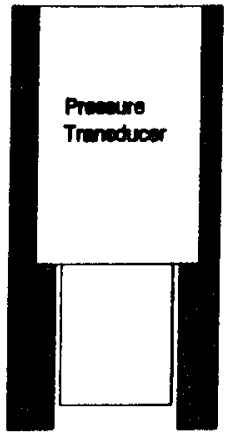

One-diameter port

- Oscillatory

- $\leq 0.030$ " offset

- Well characterized

gage

- No grease (likely

extreme thermal drift)

Recommended procedure to be used when oscillations must be studied:

- Use both two-diameter ports with grease and one-diameter ports without grease

- Use low-pass filtered pressure-time history from two-diameter port to define the "quasisteady-state", or mean pressure

- Use pressure-time from the one-diameter port, with mean pressure (with likely thermal drift effects) removed, to define the oscillatory pressure

Figure 6. Procedure for measuring both quasi-steady-state and oscillatory components of a spectrally rich combustion pressure.

content of the combustion process must be studied, this procedure should be implemented using the singlediameter gauge port configuration. The pressure gauges should be mounted $\leq 0.030$ in from the combustion gases without grease in order to resolve the input frequencies of interest (near-DC to $80 \mathrm{kHz}$ ). It is worth noting here that the participants felt that a minimum of single-diameter ports should be implemented due to the probability that the gauge may need to be replaced after every test due to extreme thermal and vibrational shock loading. Obviously this procedure could prove to be quite expensive, but at this time it is the only methodology known to successfully characterize the high-frequency combustion environment.

5.2 Alternate Pressure Transducers. Altemate pressure transducers have been developed that are designed to survive the severe thermal and oscillatory environment. Mr. Welton "Red" Phillips has designed, built, and tested a series of tourmaline pressure transducers which have proven to be quite reliable for characterizing the quasi-steady-state pressure under severe conditions. His presentation outlined the highlights of the design which makes use of tourmaline, a pressure-sensitive crystal similar to quartz, packaged in a housing very much like that of other high-pressure ballistic transducers. These gauges have been used routinely to measure quasi-steady-state combustion pressure in conventional interior ballistic testing for several years and have been demonstrated to compare quite well with other highpressure piezoelectric pressure transducers. 
Two design modifications were made to the transducers specifically for the severe oscillatory combustion environment. To eliminate the problem of the high mechanical failure rate of other ballistic transducers, the gauge was made to have a larger diameter $(14 \mathrm{~mm}, 0.551 \mathrm{in})$ than traditional high-pressure ballistic transducers $(0.375$ in). The increased diameter allows greater torque to be used when installing the transducers. Traditional transducers are only torqued to $20-25 \mathrm{ft}-\mathrm{lbs}$ whereas the tourmaline transducer can be torqued to $90 \mathrm{ft}-\mathrm{lbs}$, giving much greater mechanical stability. In addition to the larger diameter, there is also a built-in heat shield which goes a long way to prevent adverse thermal effects.

There are however, several unknowns that prohibit the use of this transducer for studying the oscillatory portion of the combustion pressure. Mr. Phillips has not quantified the transducers' resonant frequency, the rise time, nor the effects of the thermal heat shield on the high-frequency data. Consequently, the workshop participants felt that further laboratory testing should be completed before information could be gained conceming the oscillatory portion of data acquired using these transducers. It cannot be overemphasized that the transducers perform extremely well in this environment for characterizing the quasi-steady-state portion of the combustion pressure.

5.3 Altemate Pressure Measurement Techniques. Alternate pressure measurement techniques were also presented at the workshop. Mr. Jody Wormhoudt of Aerodyne Research, Inc. presented work completed under a Small Business Innovative Research (SBIR) contract for the U.S. Navy which entailed the design, manufacture, and test of a fiber optic pressure transducer for underwater blast testing. The presentation outlined the approach of using the fluorescence of ruby in conjunction with fiber optic technology to monitor detonation blast pressures to $250 \mathrm{kbar}$. The advantages of the technique were primarily that it was insensitive to electromagnetic effects because of the optical link; it had very fast response times to $0.1 \mu \mathrm{s}$; and the fact that it implemented flashlamp-excited plastic optical fiber containing fluorescent dye, and ruby crystals, all of which are relatively inexpensive and easily obtained (bulk cost similar to piezoelectric transducers). The disadvantages which currently prohibit its use in interior ballistic testing are its sensitivity to thermal effects, the insensitivity of the technique to pressure levels of interest, and the gauge's low resonant frequency. However, modifications to the technique were proposed which would allow the use of this technique in interior ballistic testing. The development time and costs were not estimated.

The CSTA, of the Test and Evaluation Command (TECOM) of the U.S. Army, has been actively pursuing fiber optic pressure transducers for electrothermal/electromagnetic gun propulsion application 
because of their insensitivity to electromagnetic interference. To this end, they have initiated several SBIR contracts to various companies to explore the feasibility and implementation of fiber optic technology in the measurement of interior ballistic combustion pressure. The CSTA point of contact, Mr. W. Scott Walton, was not able to attend the workshop; however, a survey of the promising SBIR programs was presented by the workshop chairman after close consultation with Mr. Walton.

The presentation on fiber optic pressure transducers was prefaced with Mr. Rosenberger stating that the interior ballistic community has not heard much in the way of fiber optic pressure measurement technology because it is a relatively immature, rapidly changing technology. There has been a great deal of work done in the area, but not much has been written in the U.S. because it has been held proprietary. Three techniques were discussed in the presentation. The most promising fiber optic pressure measurement technique was patented by Quest Inc. and is based on light intensity reduction due to diaphragm displacement (U.S. patent 4,158,310). It is packaged in a transducer that has the form function of a Kistler 6211 high-pressure ballistic transducer. Fibers which include both illuminating and receiving fibers are bundled together and placed in close proximity to a reflective diaphragm. The diaphragm is exposed directly to the combustion gases. As the diaphragm flexes under pressure, the reflected light intensity changes in a manner proportional to the input pressure. The reflected light is sensed by a remotely located photodetector via the receiving fiber optic link. This transducer was statically demonstrated to $945 \mathrm{MPa}$ and dynamically demonstrated using a pressure pulse generator to $690 \mathrm{MPa}$. Some of the disadvantages of this technique are its low resonant frequency (160 kHz) and susceptibility to mechanical failure. Modifications to eliminate these problems are being implemented under a Phase II SBIR, and the transducer should be ready for testing at CSTA/ARL during the spring of 1994.

Although fiber optic pressure measurement technology appears to be too immature for characterizing the oscillatory portion of the interior ballistic combustion pressure immediately, the technology is rapidly maturing and the consensus among the workshop participants was that the technology was worth exploring further.

\section{CONCLUSIONS AND RECOMMENDATIONS}

The attendees were in agreement that the pressure measurement techniques presently being used to characterize the transient, high-frequency combustion environment in several of the advanced propulsion technologies are inadequate and consequently of serious technical concem. The specific issues of 
paramount concern were the inappropriateness of using two-diameter pressure transducer ports to characterize the oscillatory nature of the combustion pressure in RLPGs and in-bore ramjets, and the practice of operating at the limit of present pressure transducer technology specifications.

Theoretical and experimental data were presented which demonstrate that two-diameter pressure transducer mounting configurations filled with grease to eliminate thermal effects have the effect of limiting the frequency response of the measurement to $6-8 \mathrm{kHz}$. The portion of the data with frequency content near the resonant frequency of the cavity is amplified, while the portions of the data with frequency content significantly above the resonant frequency are severely attenuated. Consequently the oscillatory portion of the pressure database that has been accumulated to date is biased above $6-8 \mathrm{kHz}$. A procedure was put forward that would allow one to accurately measure the quasi-steady-state, or mean pressure, as well as the oscillatory portion of the combustion pressure. The consensus of the workshop participants was that this procedure would provide an accurate characterization of both portions of the pressure data. There was also some discussion as to whether a "correction factor" could be applied to data acquired using a two-diameter pressure port to account for the frequency limitations at the higher frequencies. Consensus could not be reached as to whether or not it would be possible to accurately apply this "correction factor;" however, consensus was reached that the concept deserved further investigation.

The tourmaline pressure transducer which implements a larger diameter and built-in thermal protection is viewed by the workshop participants as a means of decreasing the failure rate of the pressure transducers in this environment, but should only be used for quasi-steady-state measurements due to the unknown technical specifications concerning the transducer's resonant frequency, rise time, and the effects of the thermal protection on the oscillatory measurement. In addition, fiber optic pressure measurement techniques were presented which seem to have possible application to the transient, high-frequency environment of RLPGs and in-bore ramjets; as well as to the high electrical noise environment of electromagnetic and electrothermal guns. It was the consensus of the participants that more basic research was needed to explore altemative pressure measurement techniques and to attempt to quantify the technical specifications of transducers currently being used to characterize highly transient, spectrally rich combustion environments. 
INTENTIONALLY LEFT BLANK. 


\section{REFERENCES}

Benedetti, G. A. "Dynamic Response of a Transducer Mounted at One End of an Acoustical Cavity." SAND92-8003, Sandia National Laboratories, Livermore, CA, April 1993. 
INTENTIONALLY LEFT BLANK. 
APPENDIX A:

PRESENTATION - "MEASUREMENT TECHNIQUES IN HIGHLY TRANSIENT, SPECTRALLY RICH COMBUSTION ENVIRONMENTS:

WELCOME, WORKSHOP MOTIVATION AND OBJECTIVES"

This Appendix is presented in its original form without editorial changes or comments. 
INTENTIONALLY LEFT BLANK.

20 


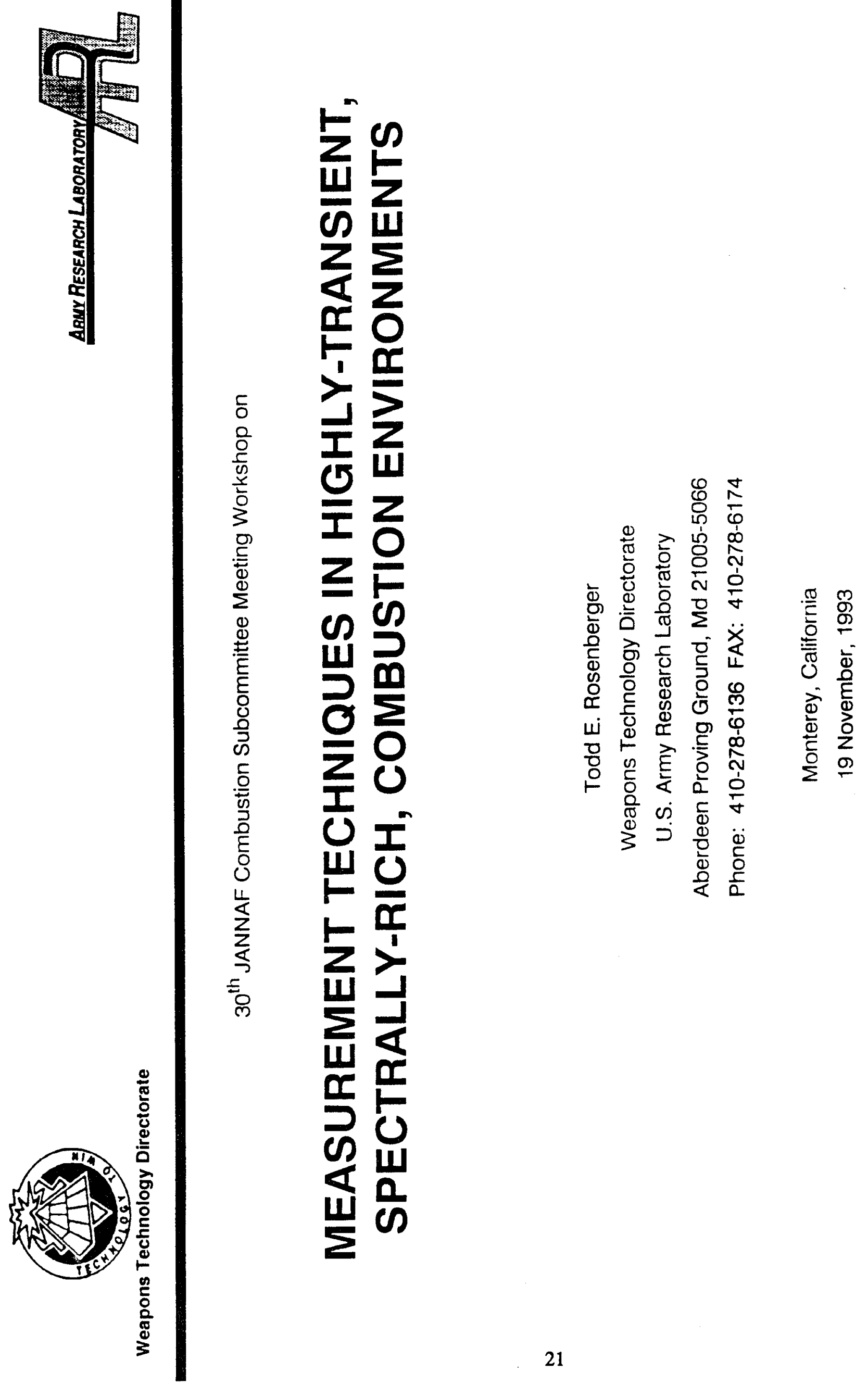


INTENTIONALLY LEFT BLANK.

22 


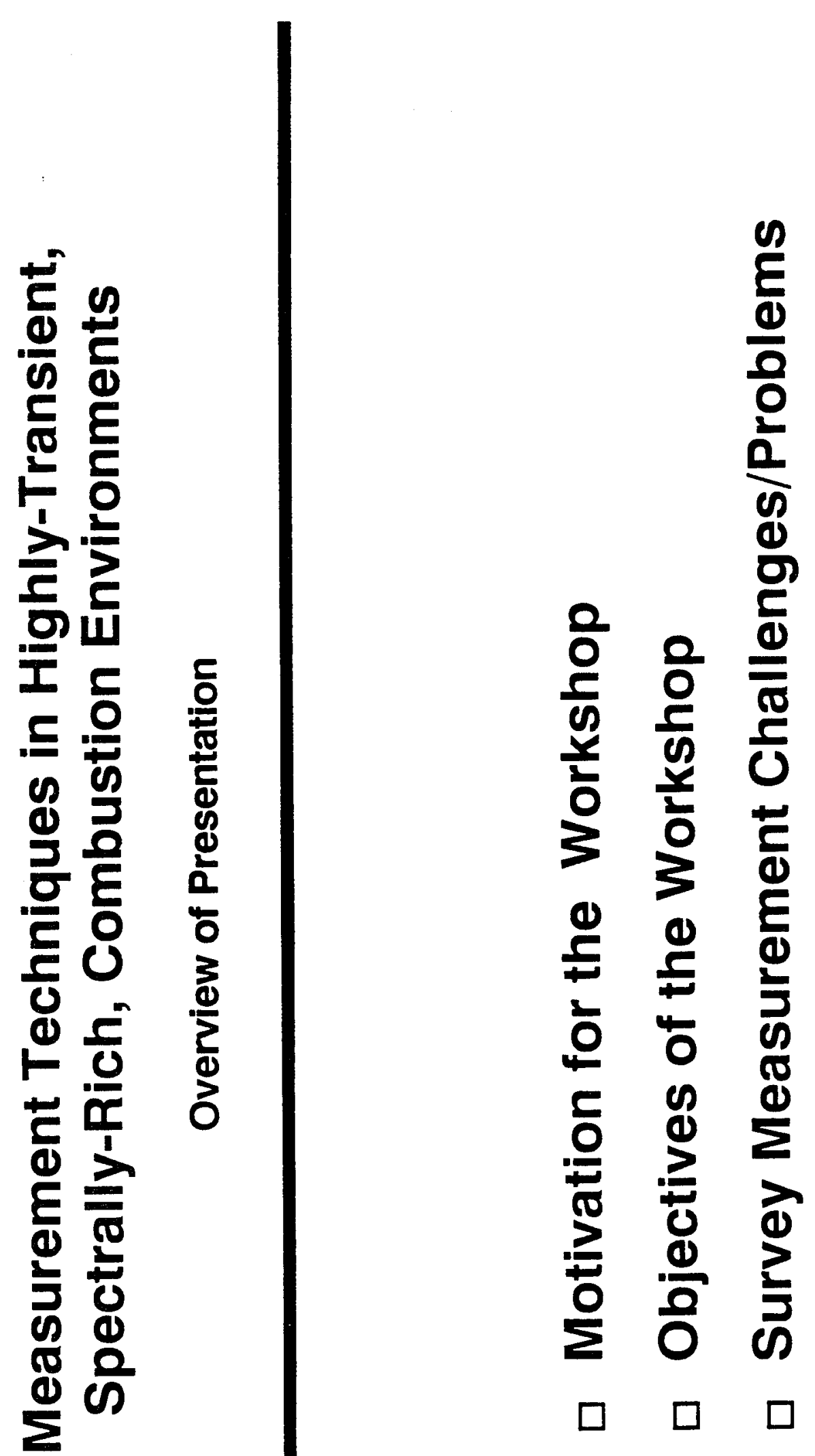




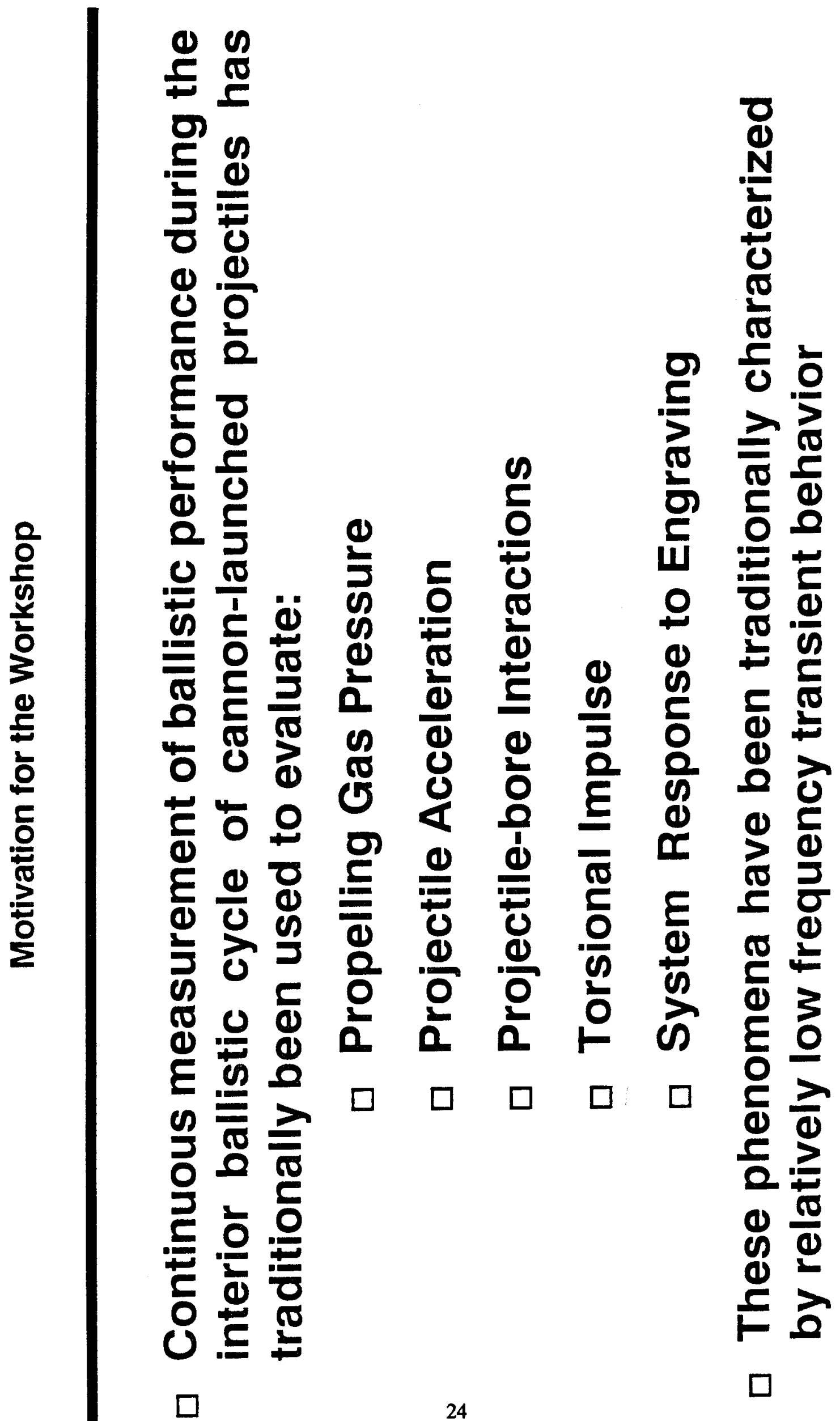




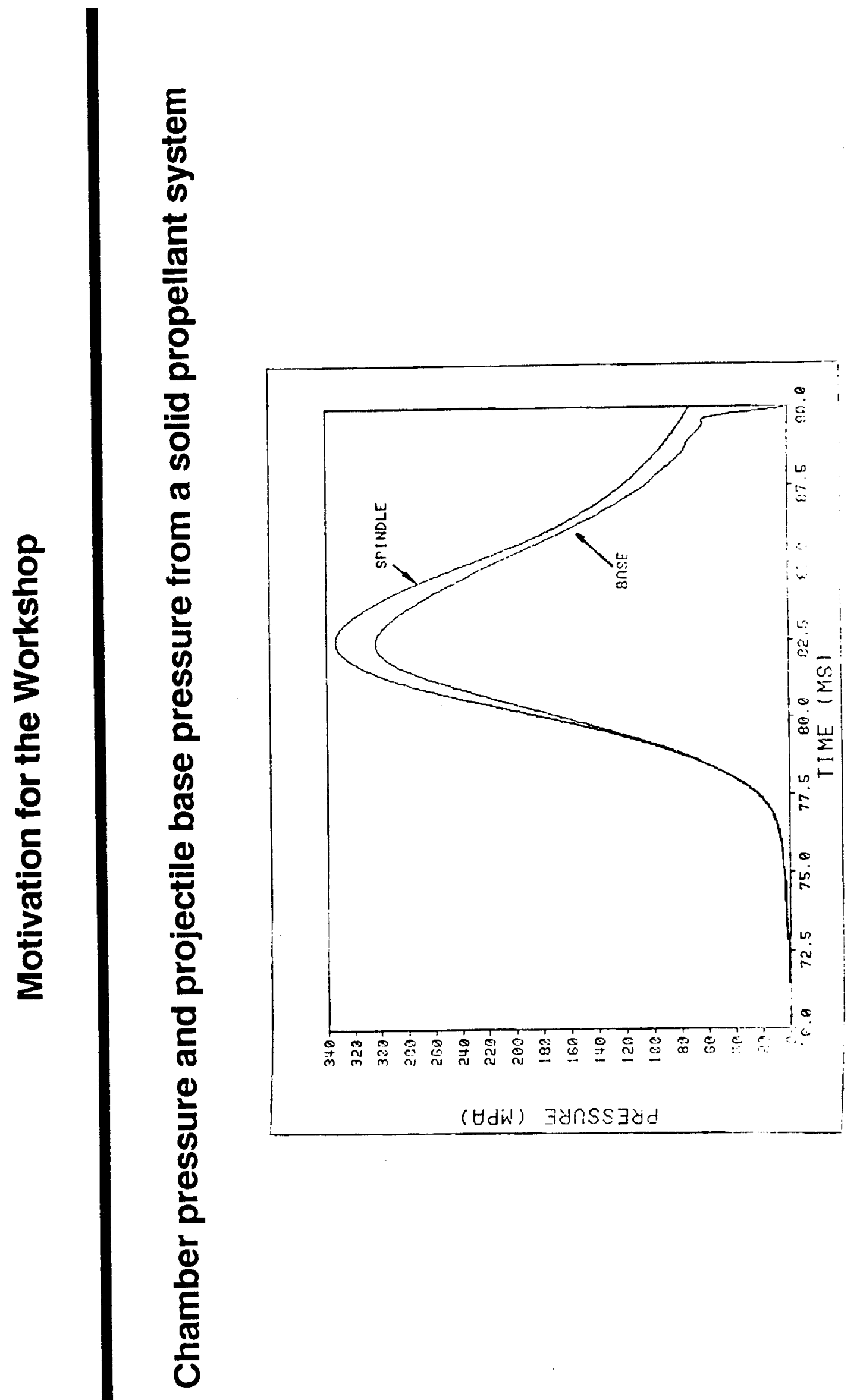




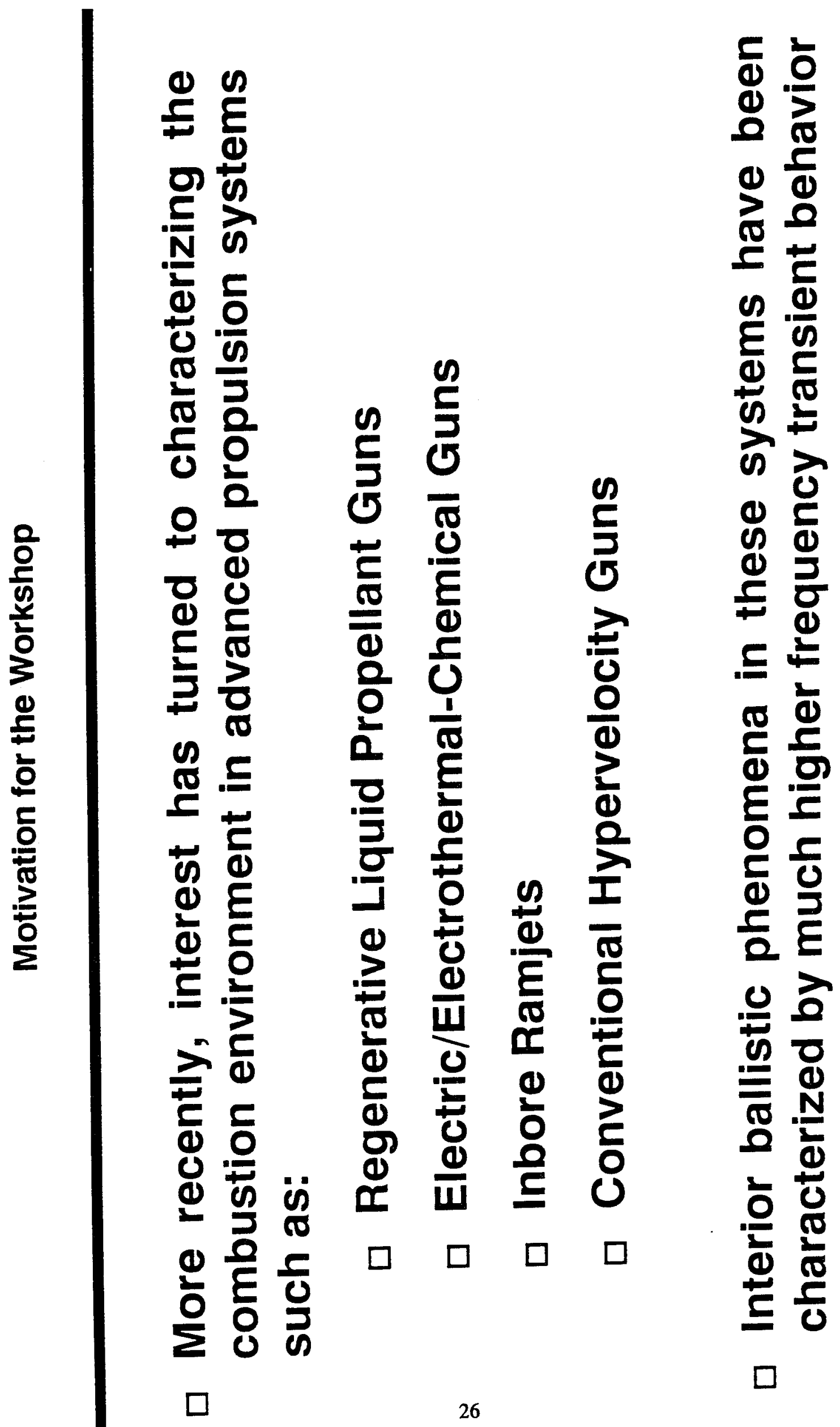




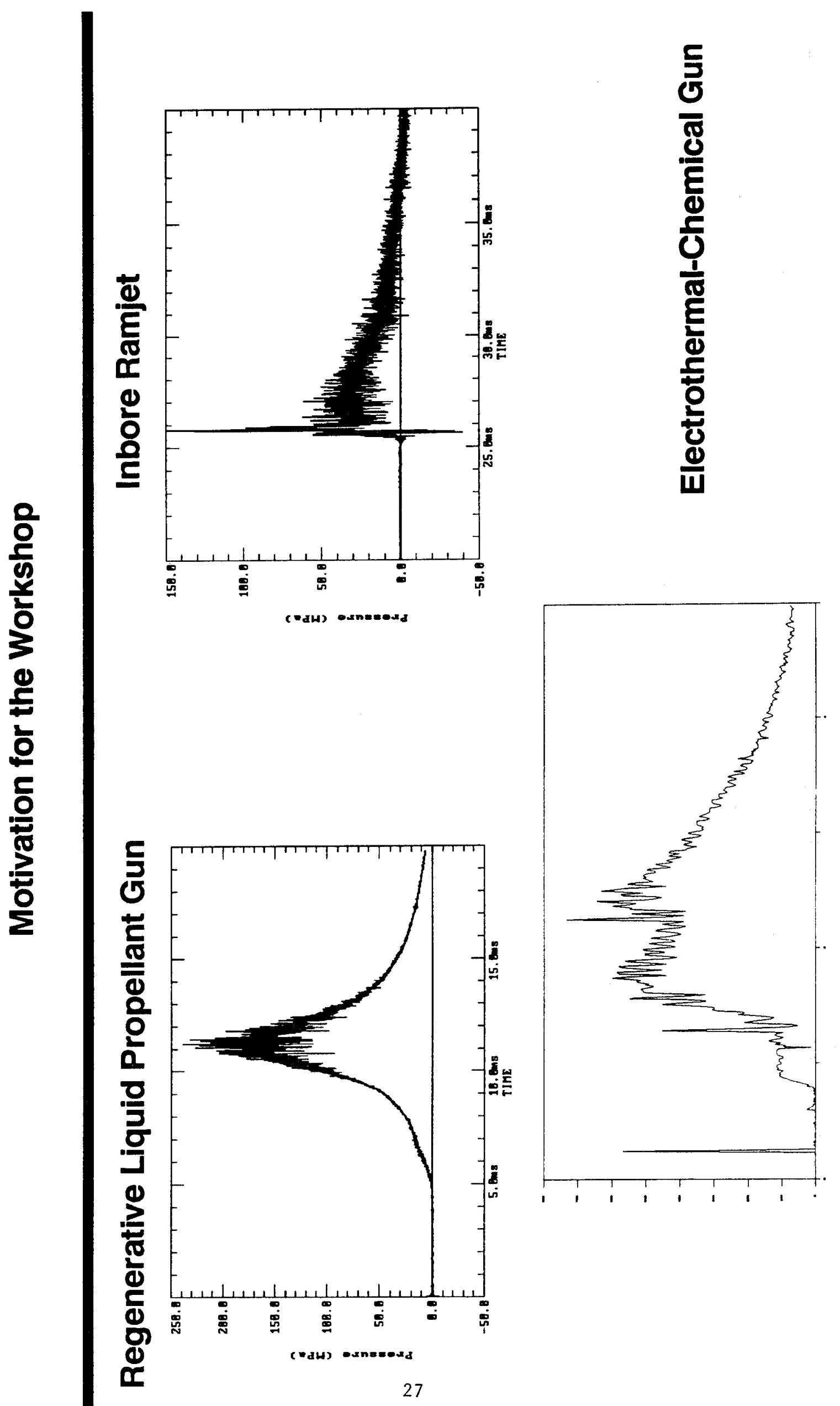




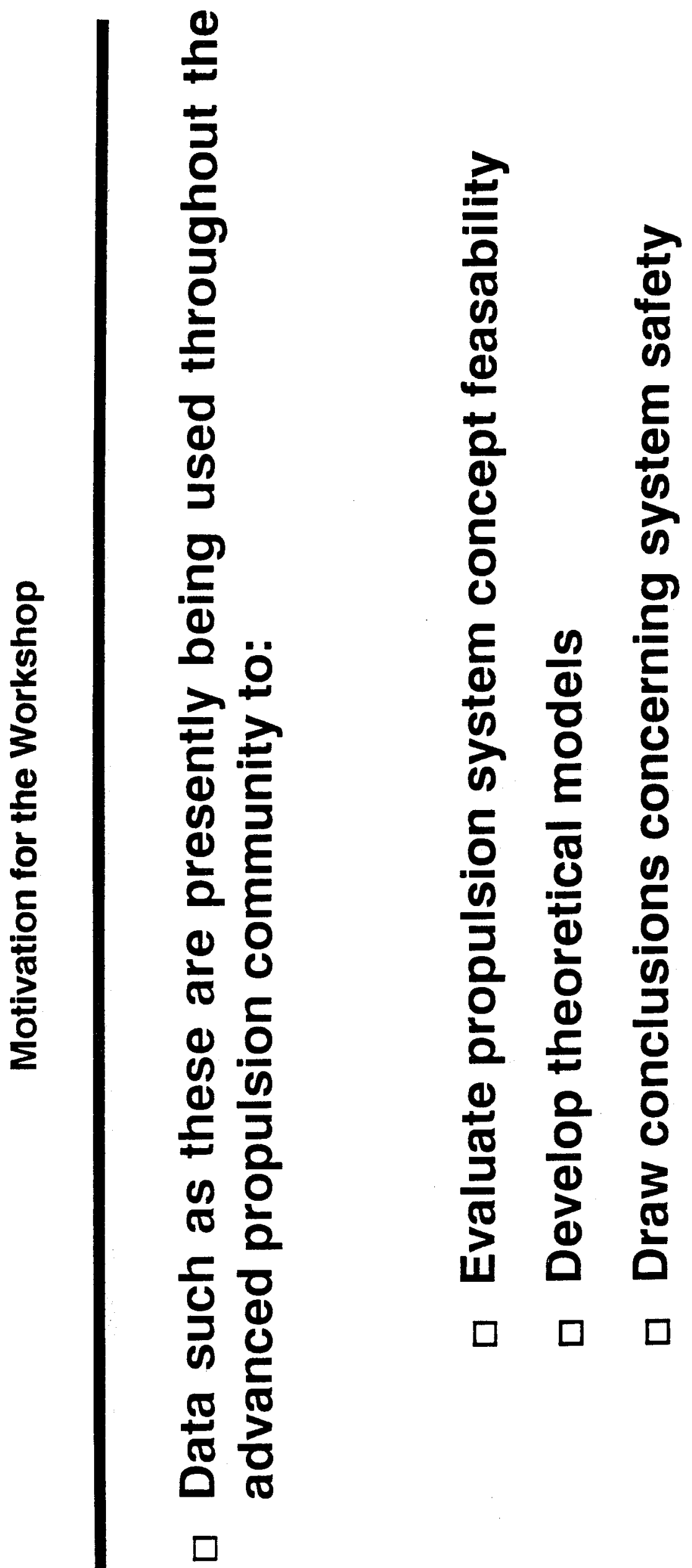



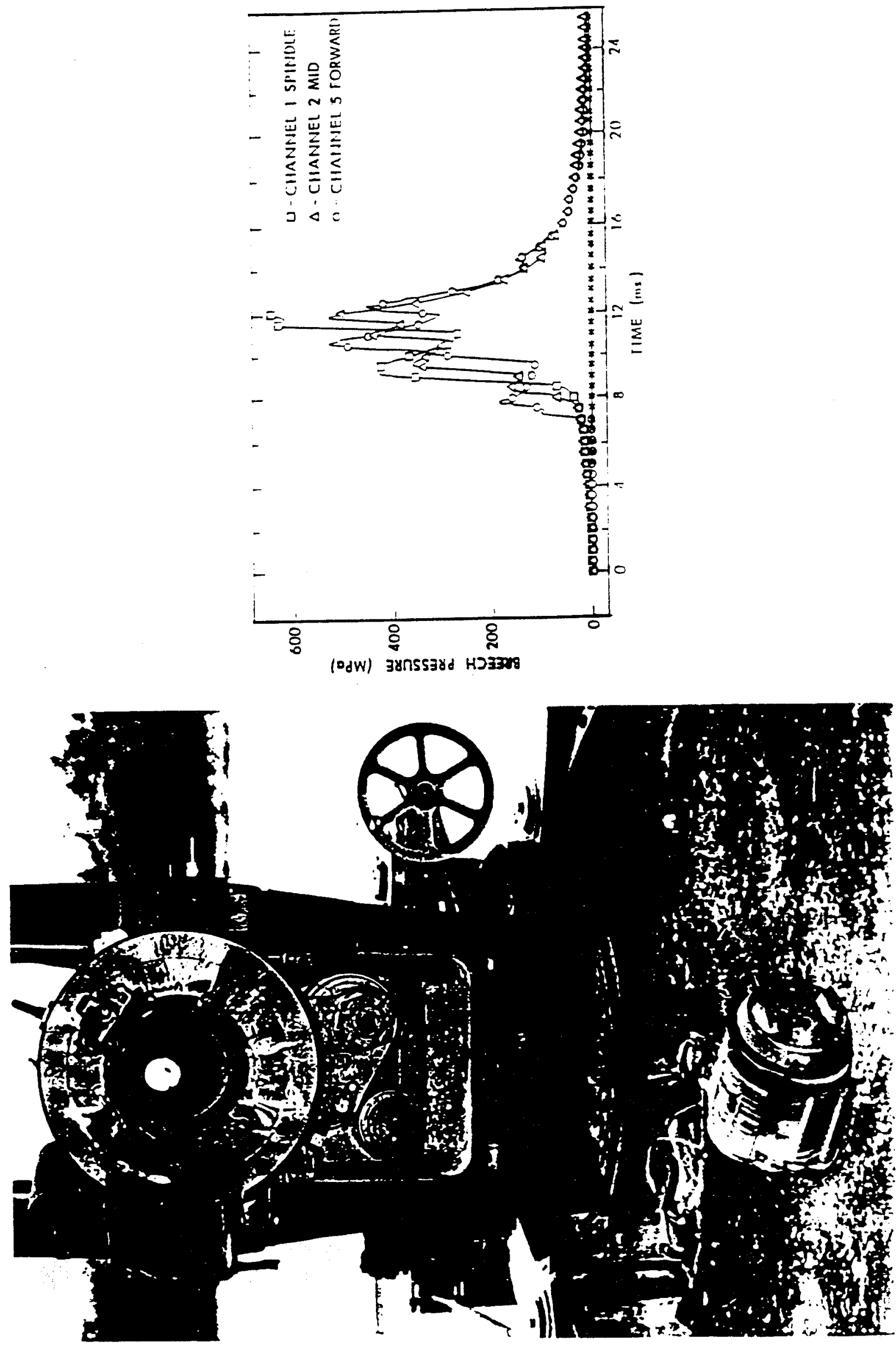


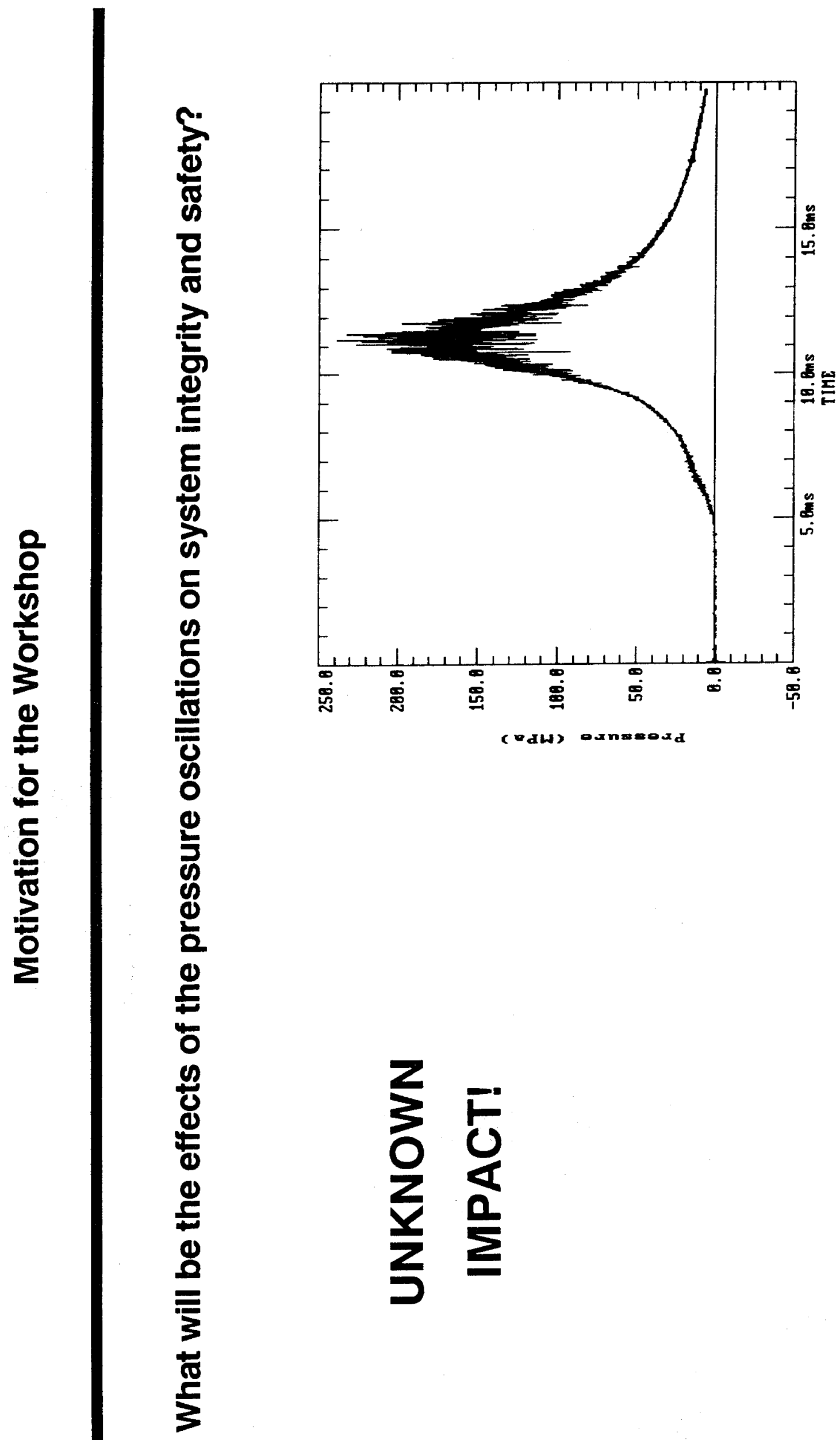




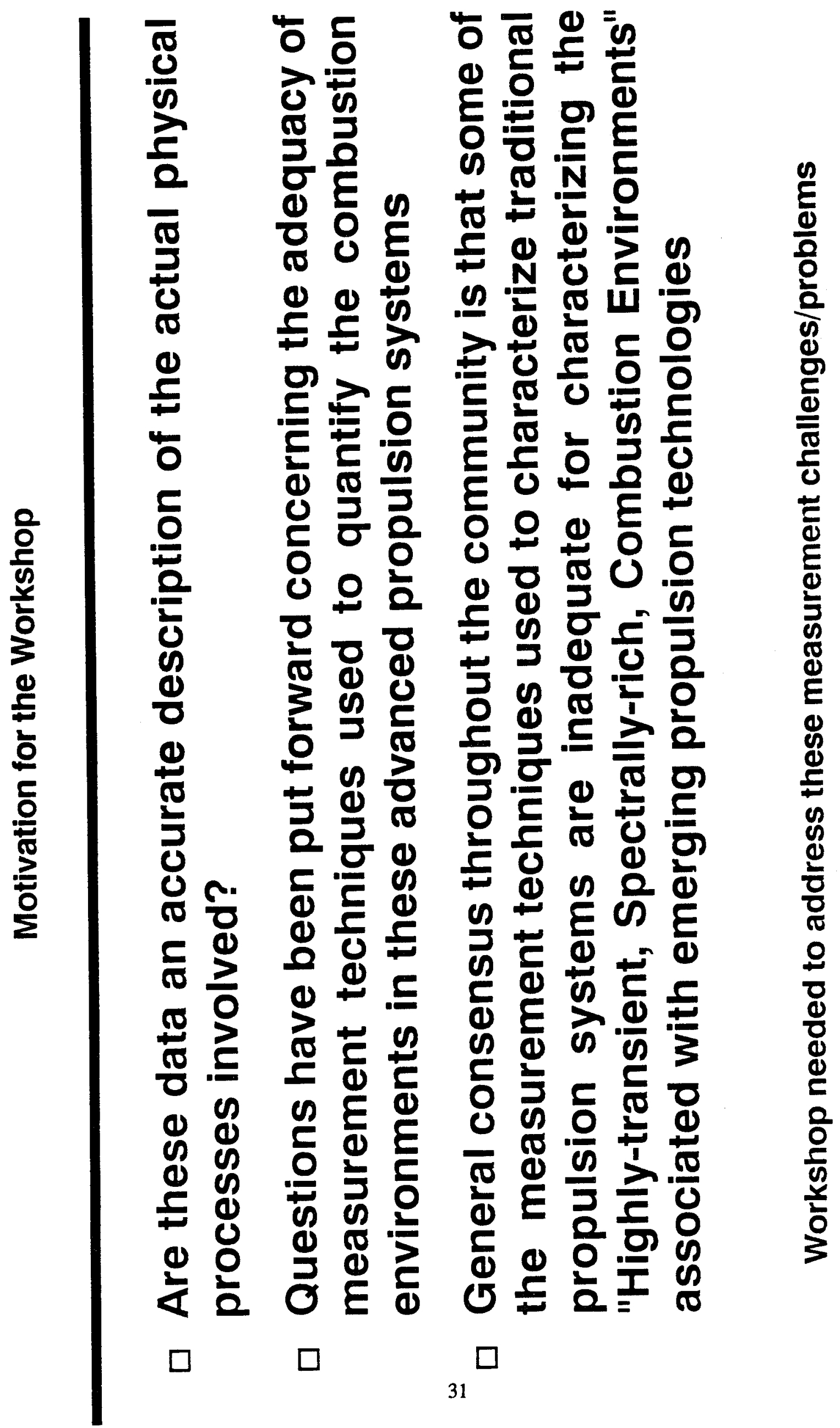




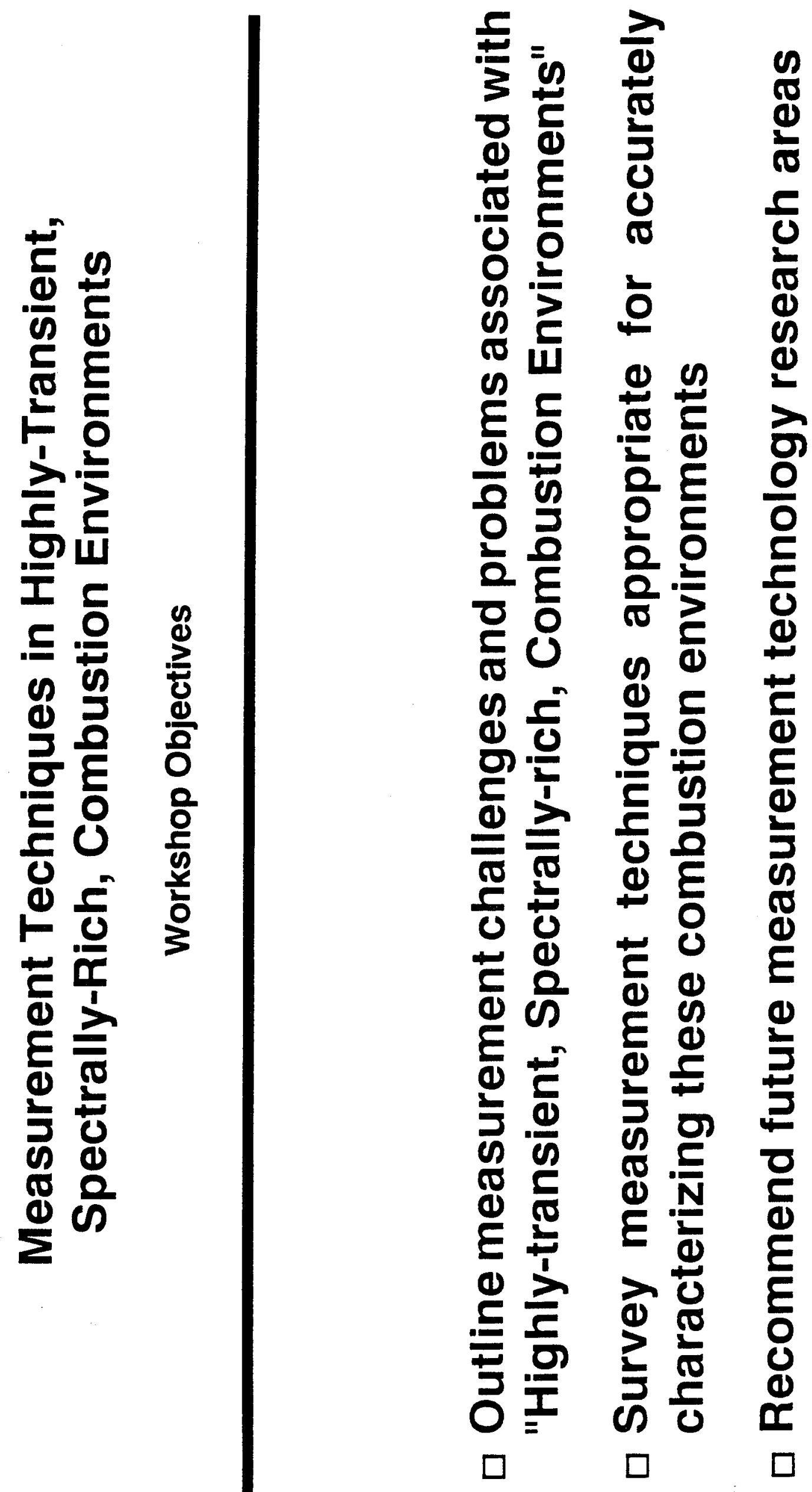



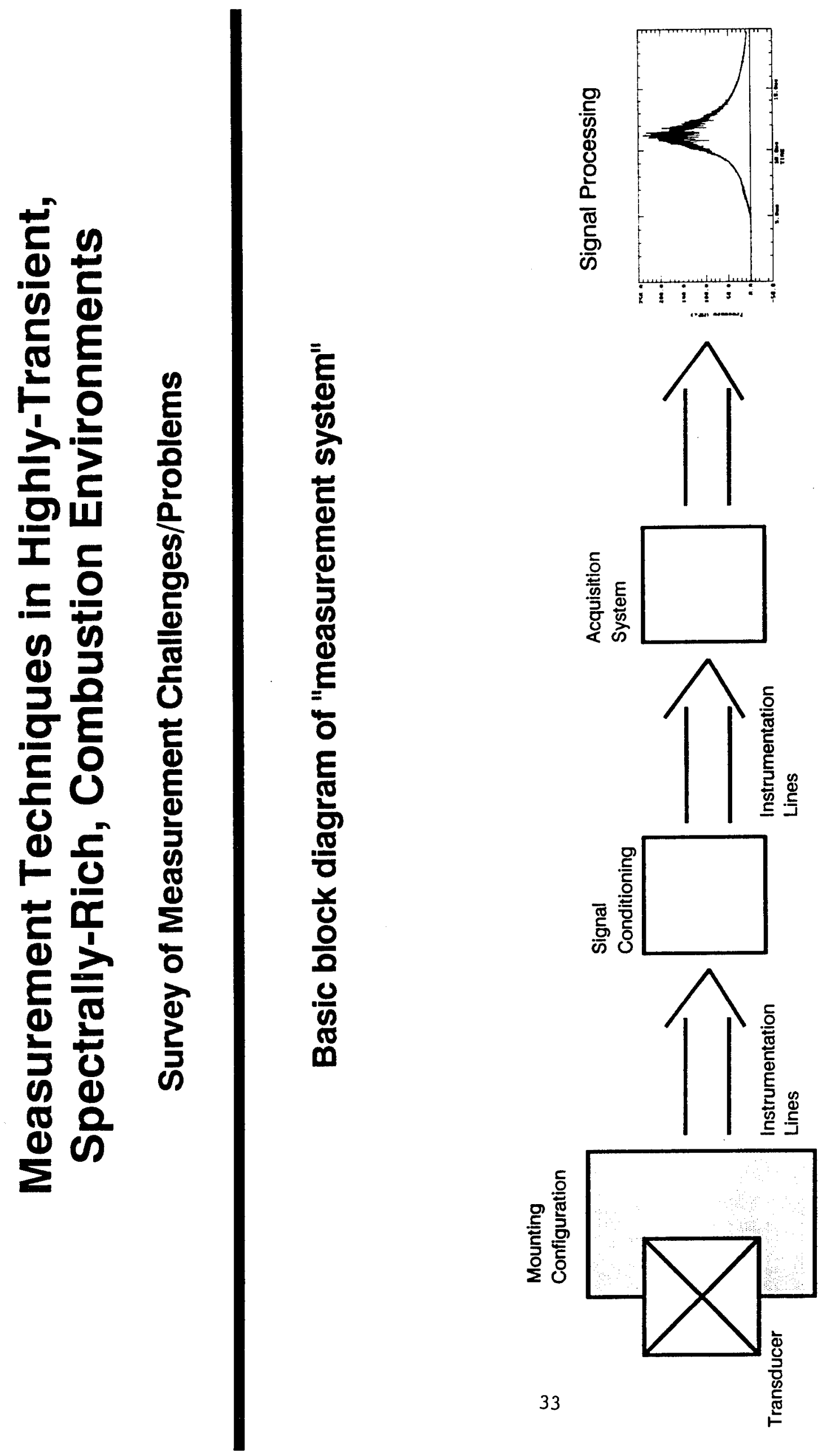

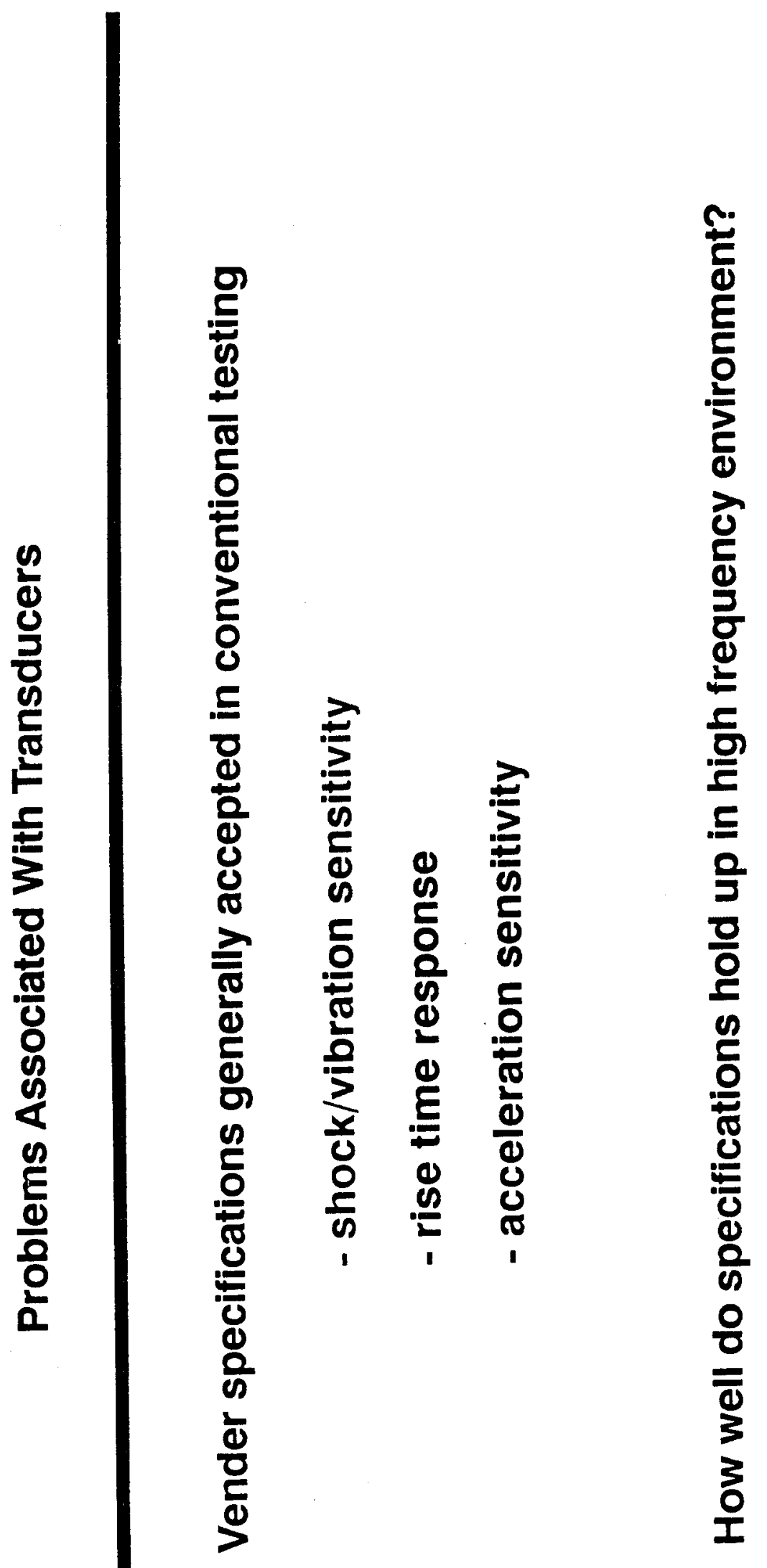


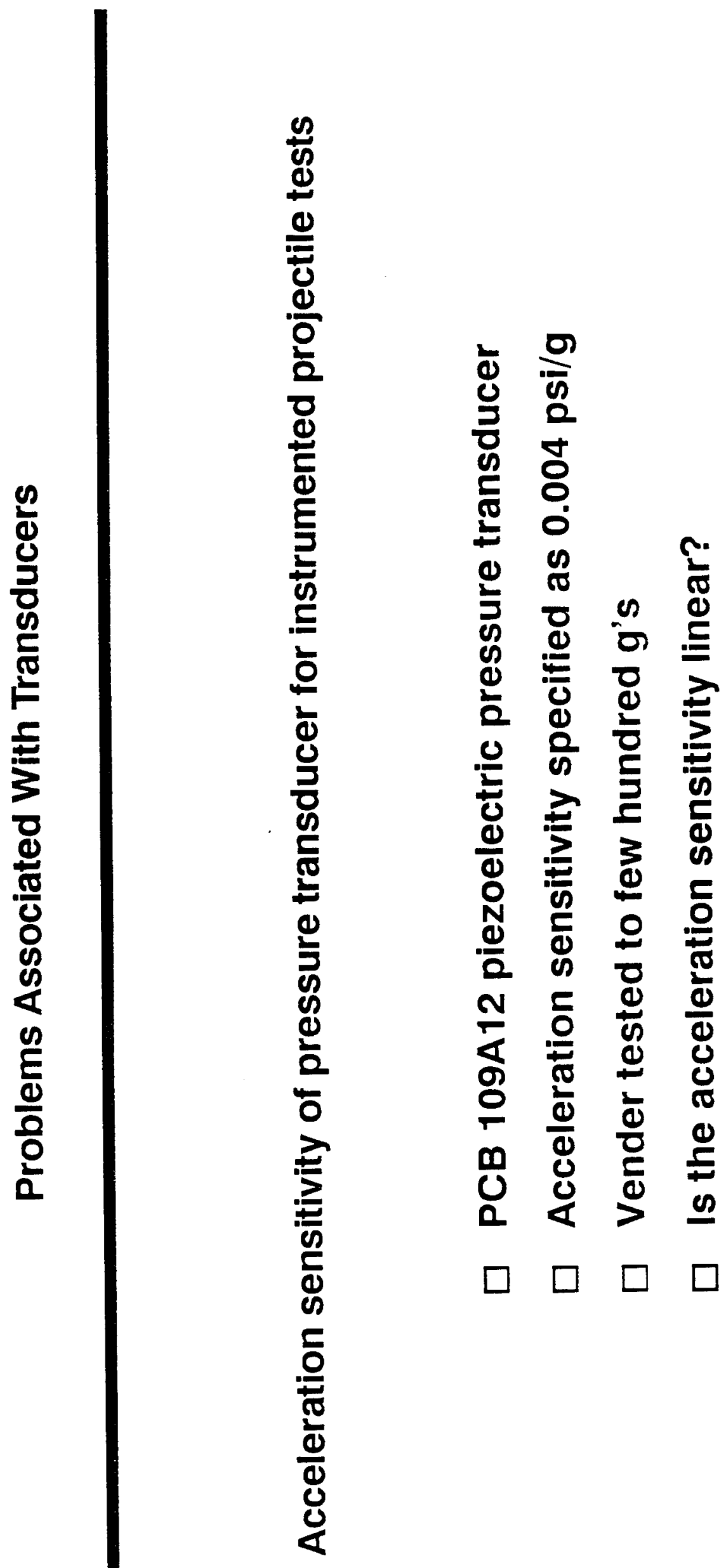




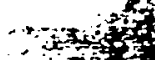

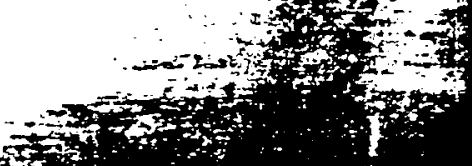
$-\frac{1}{2}=0$
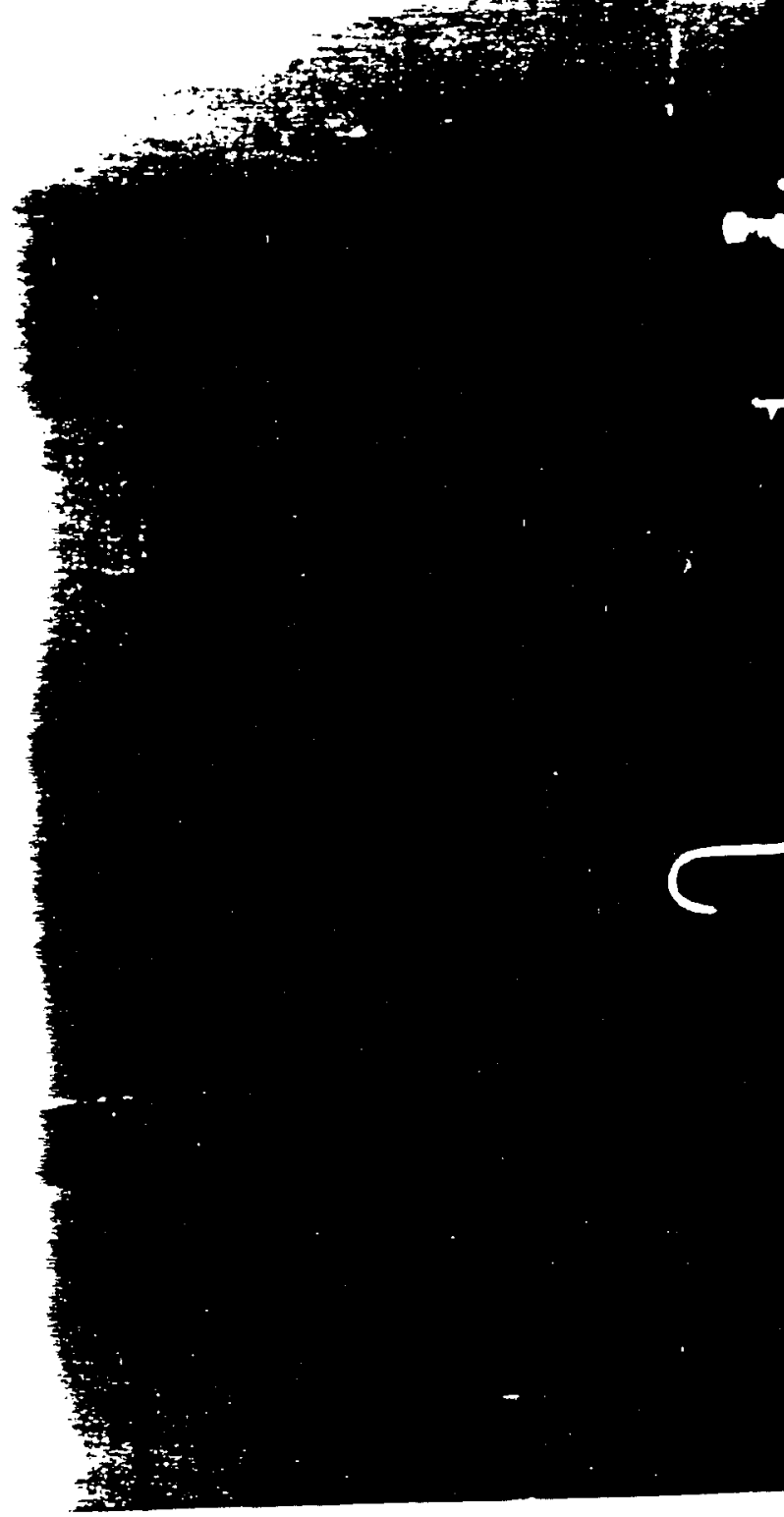
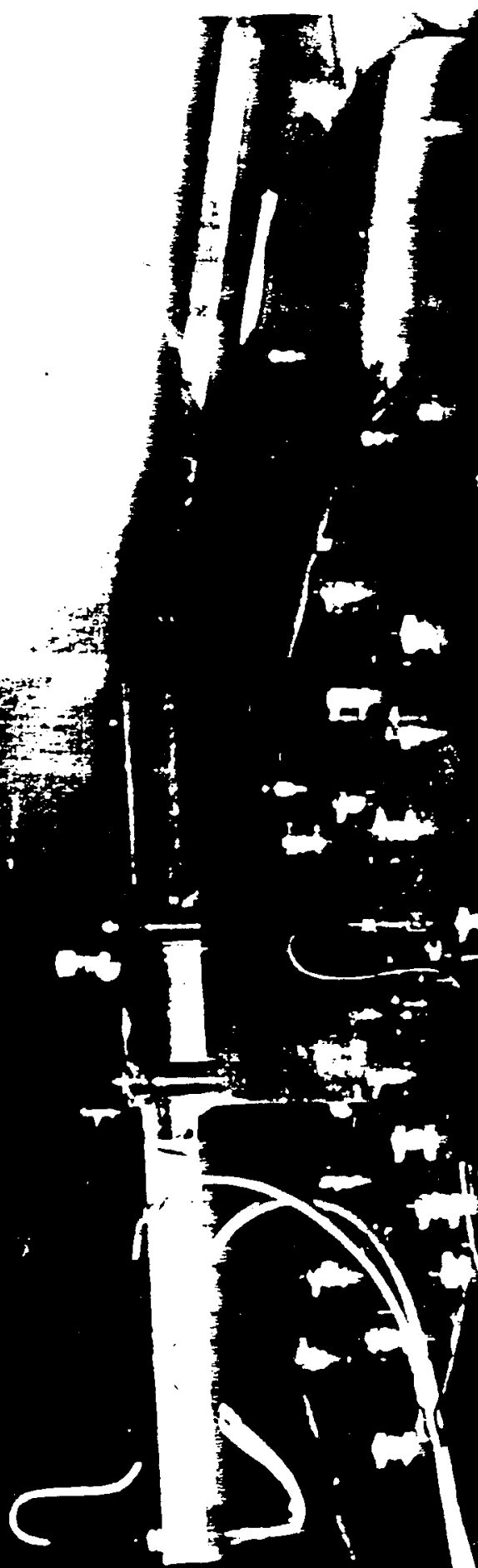

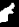

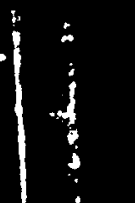


$i$
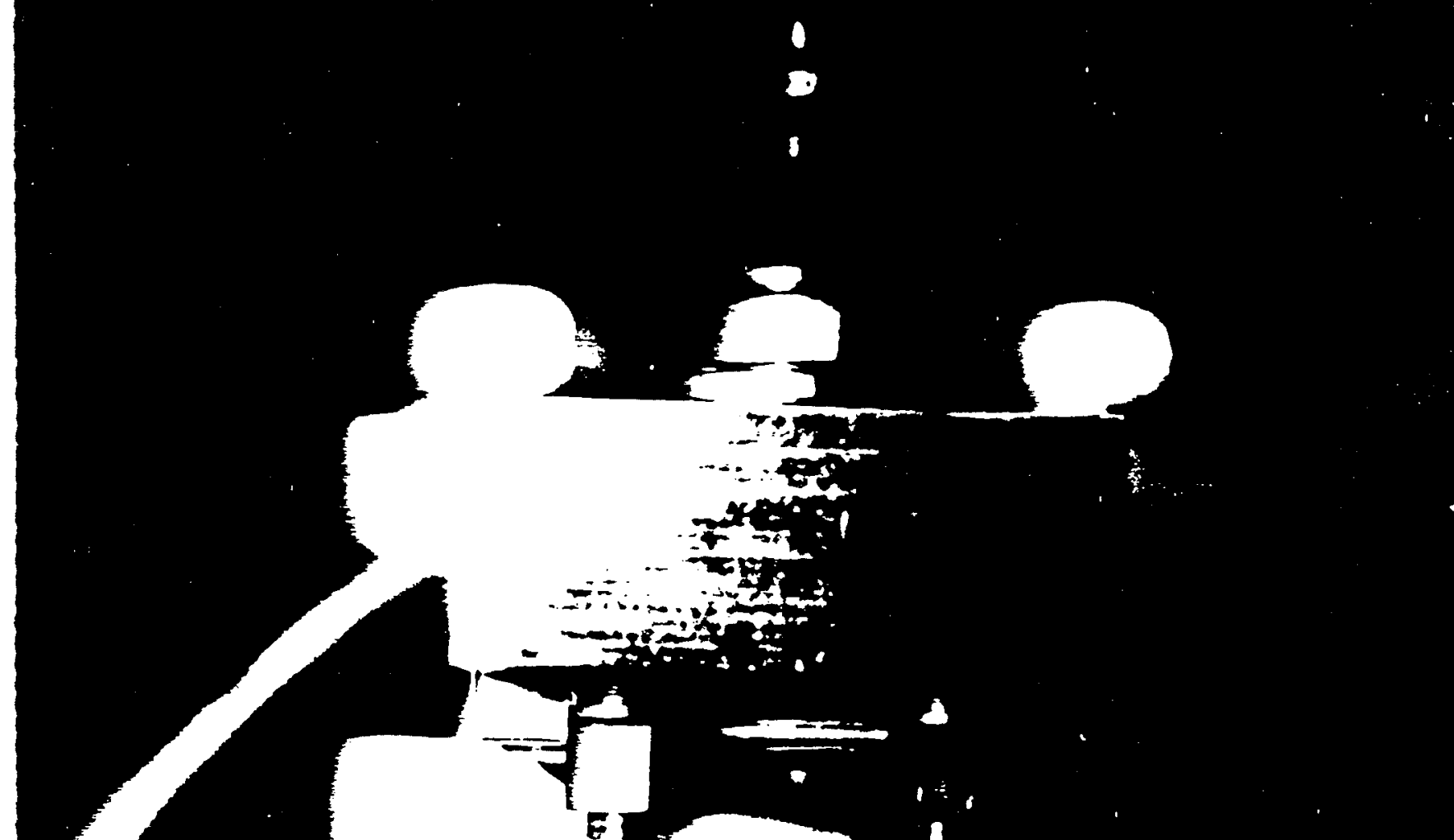

-

$=-\frac{1}{2}+\infty$

E

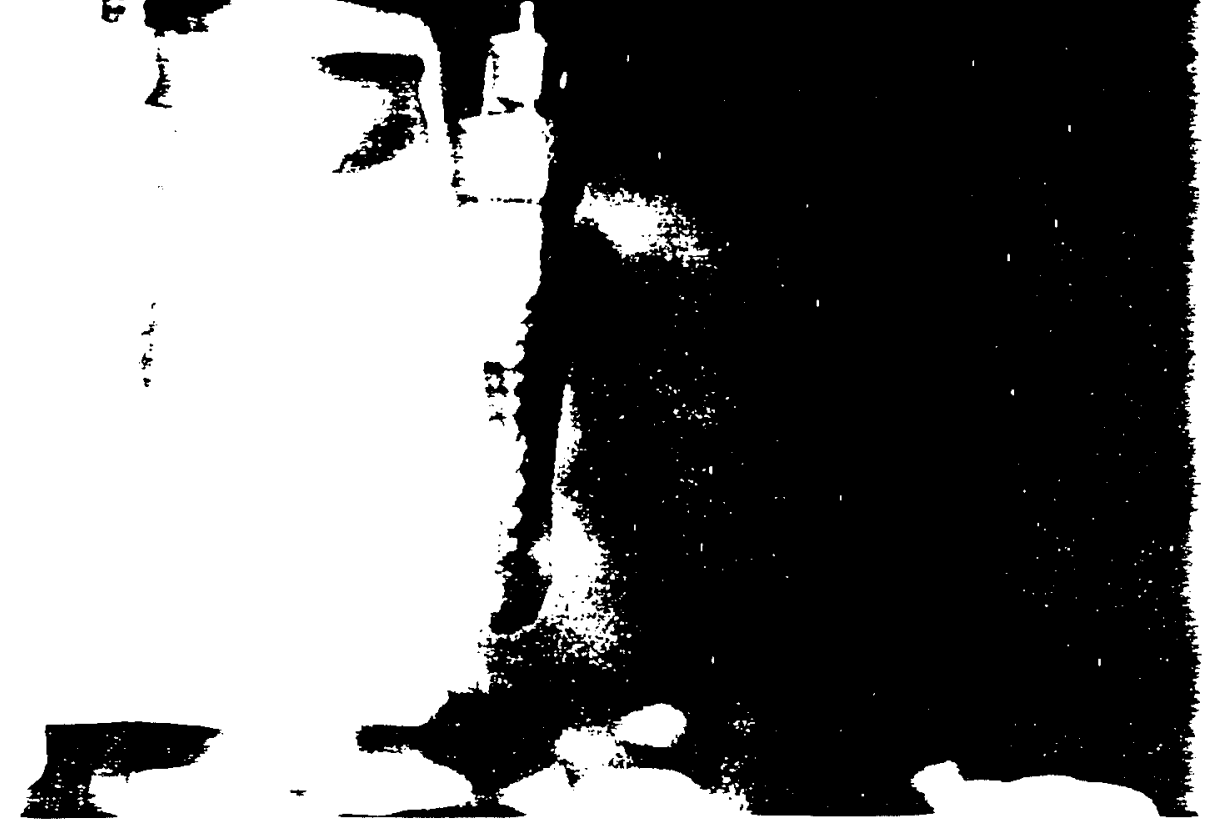


Appiiec Accoieration

$-500$

$=200$.

$500+$

$: 000$

G's

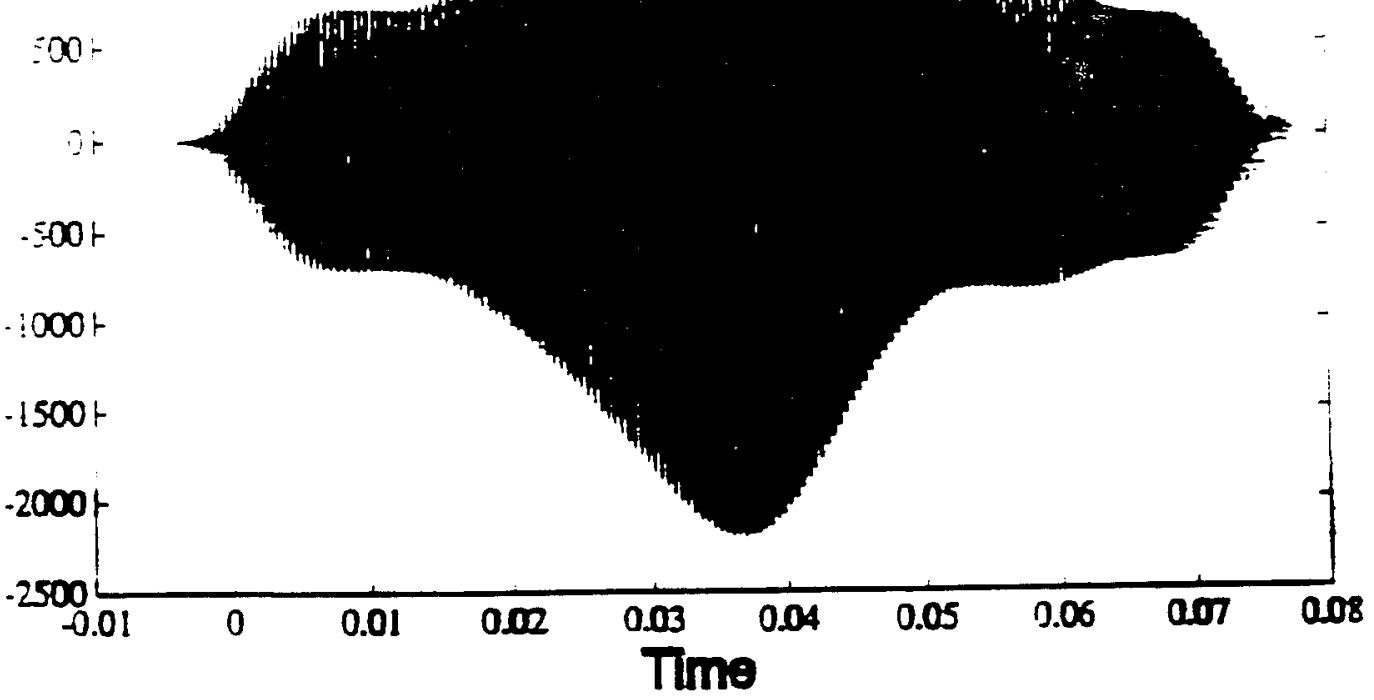

\section{PCB Specimen Response} io

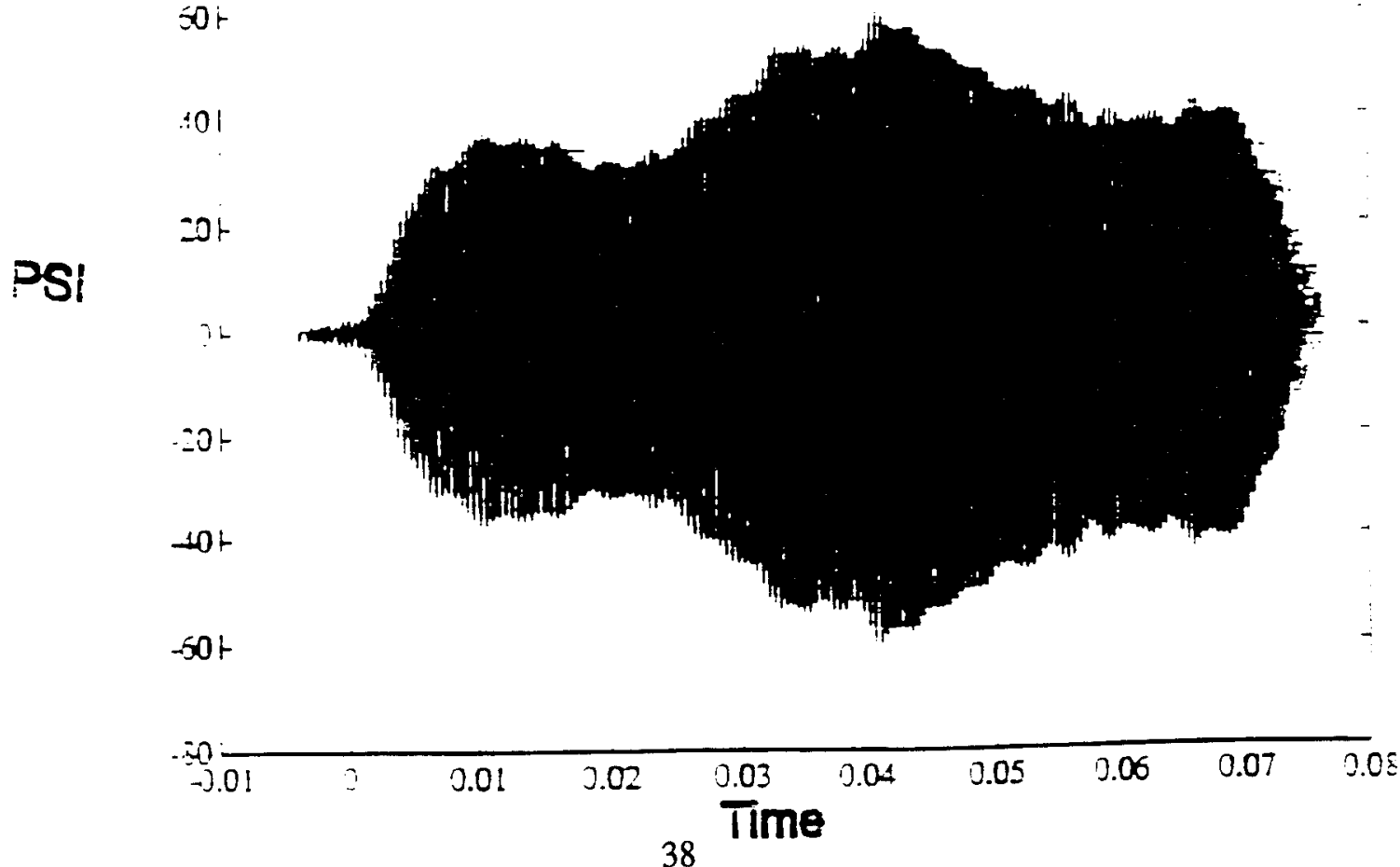



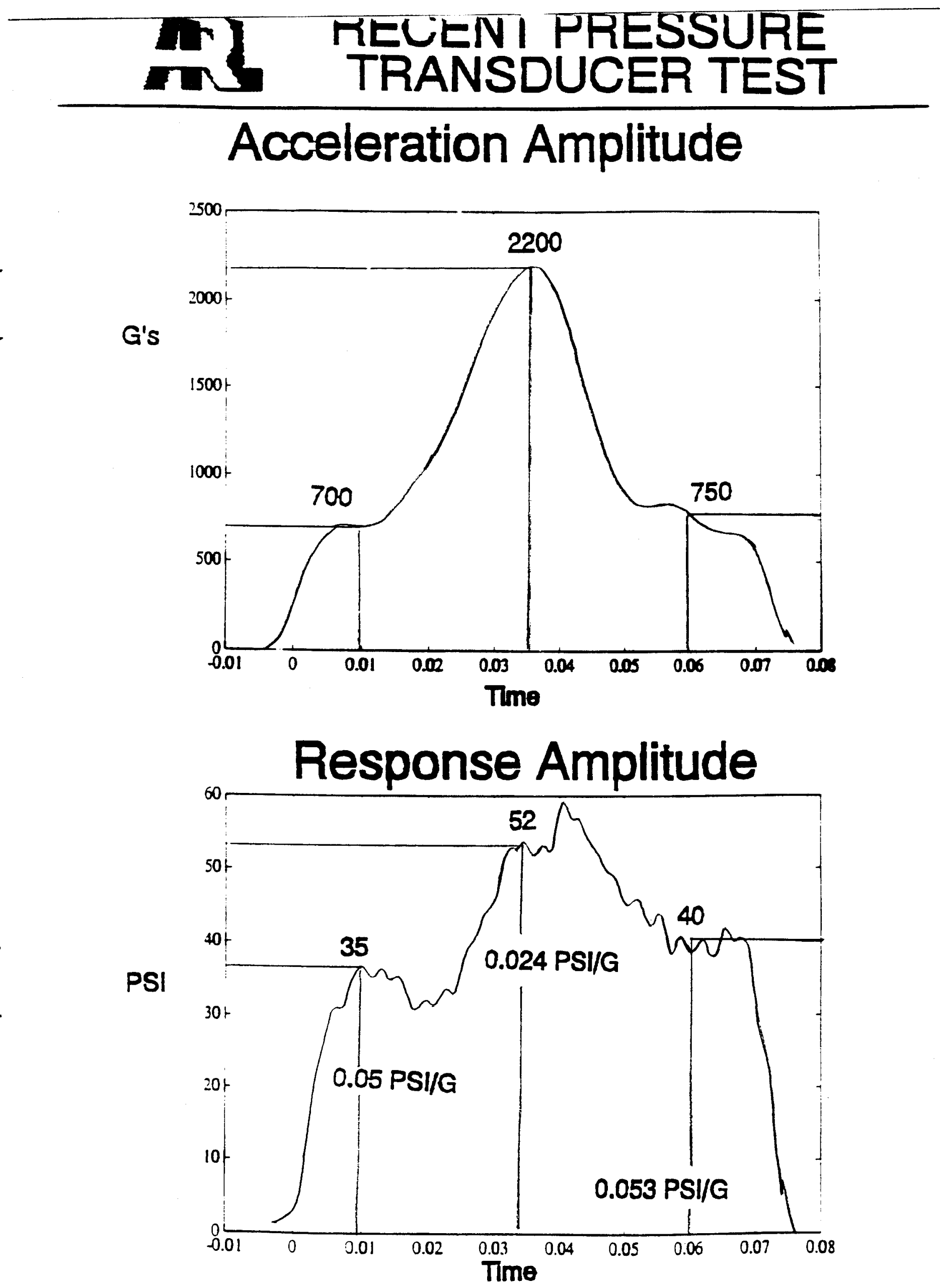


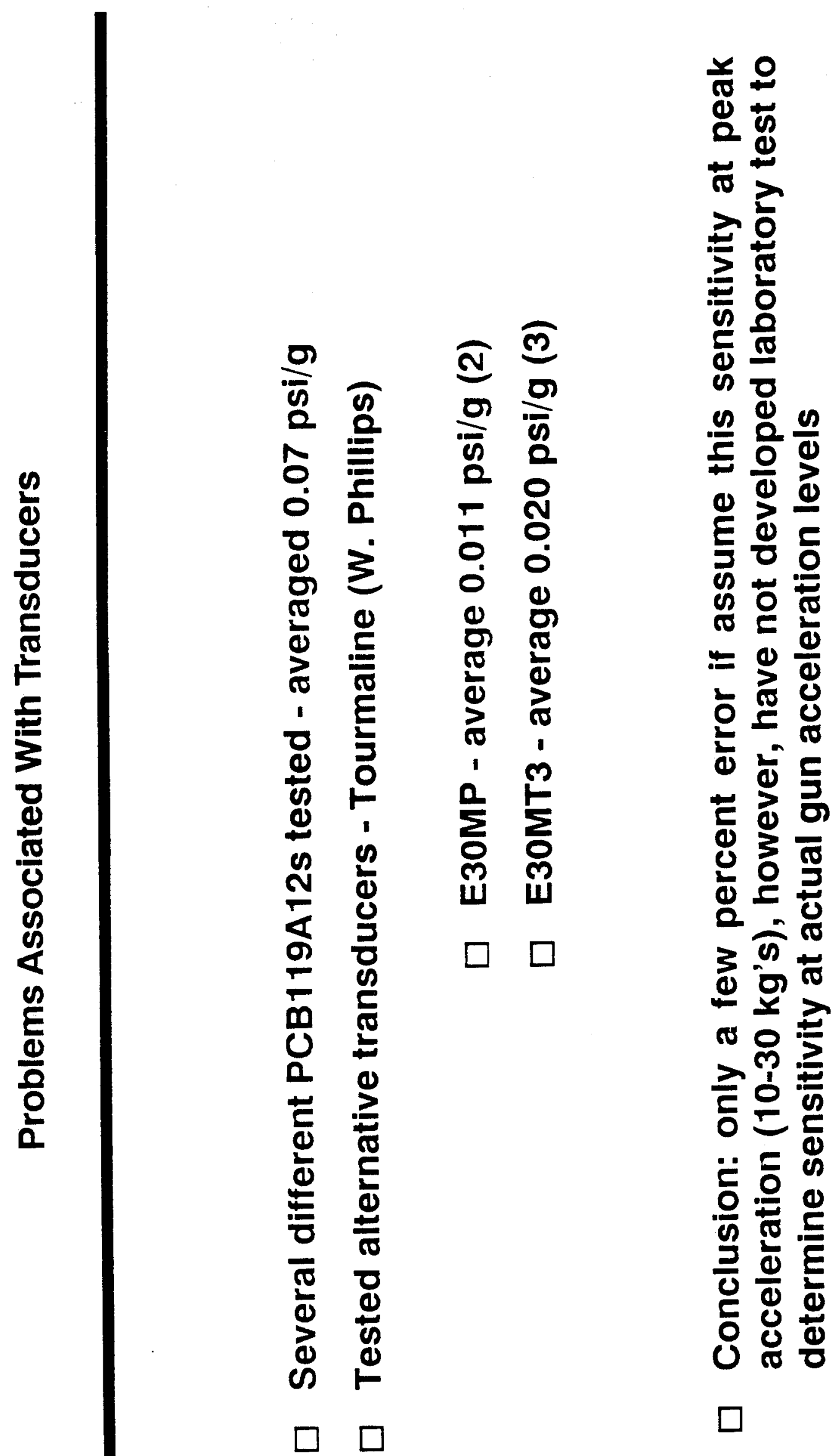




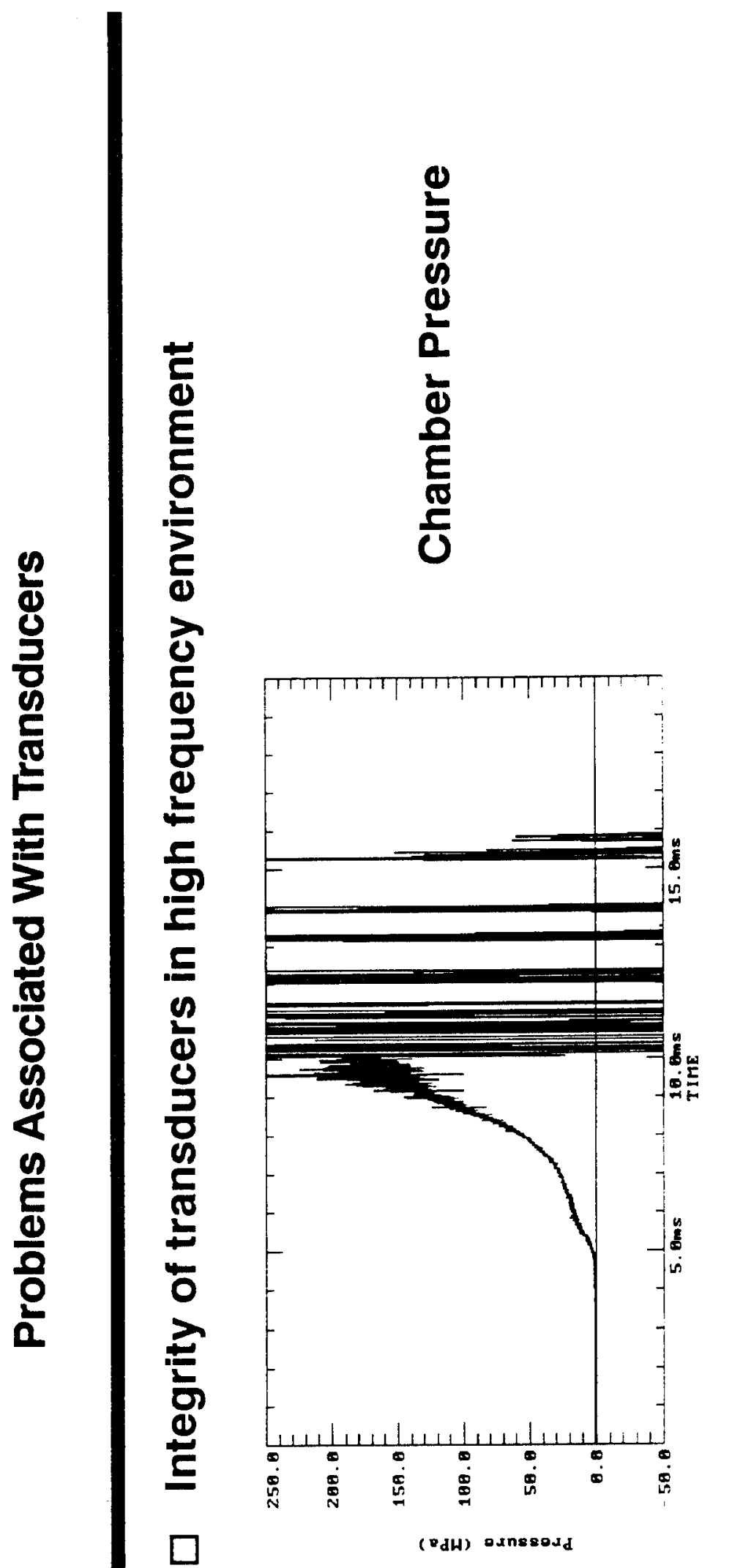

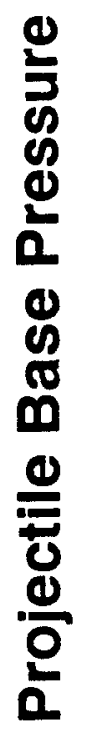

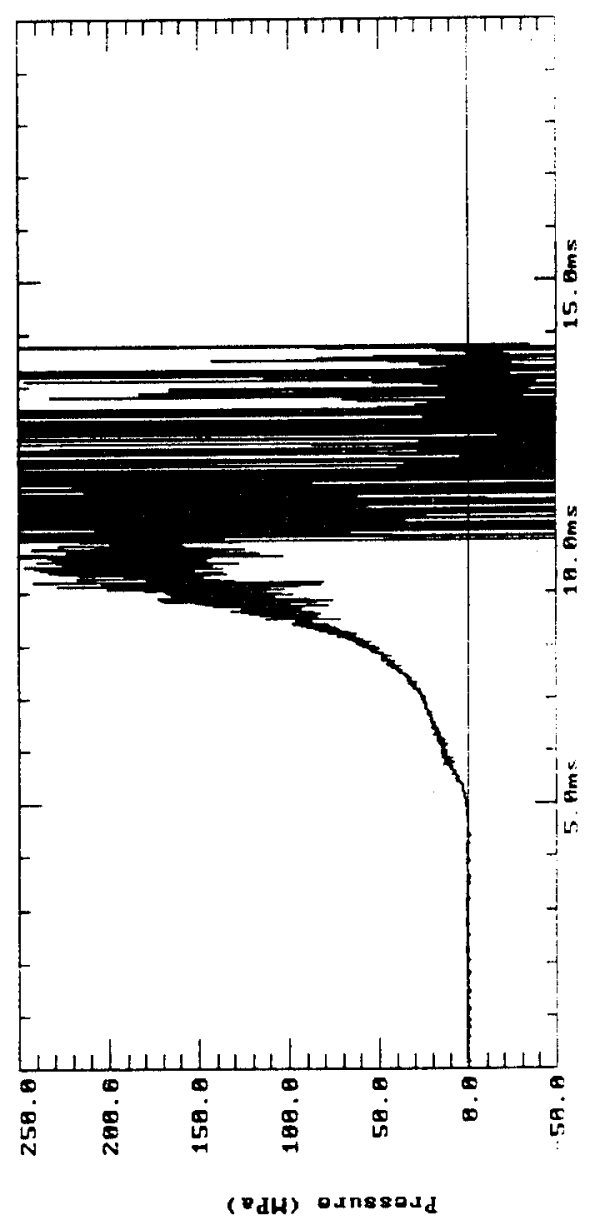



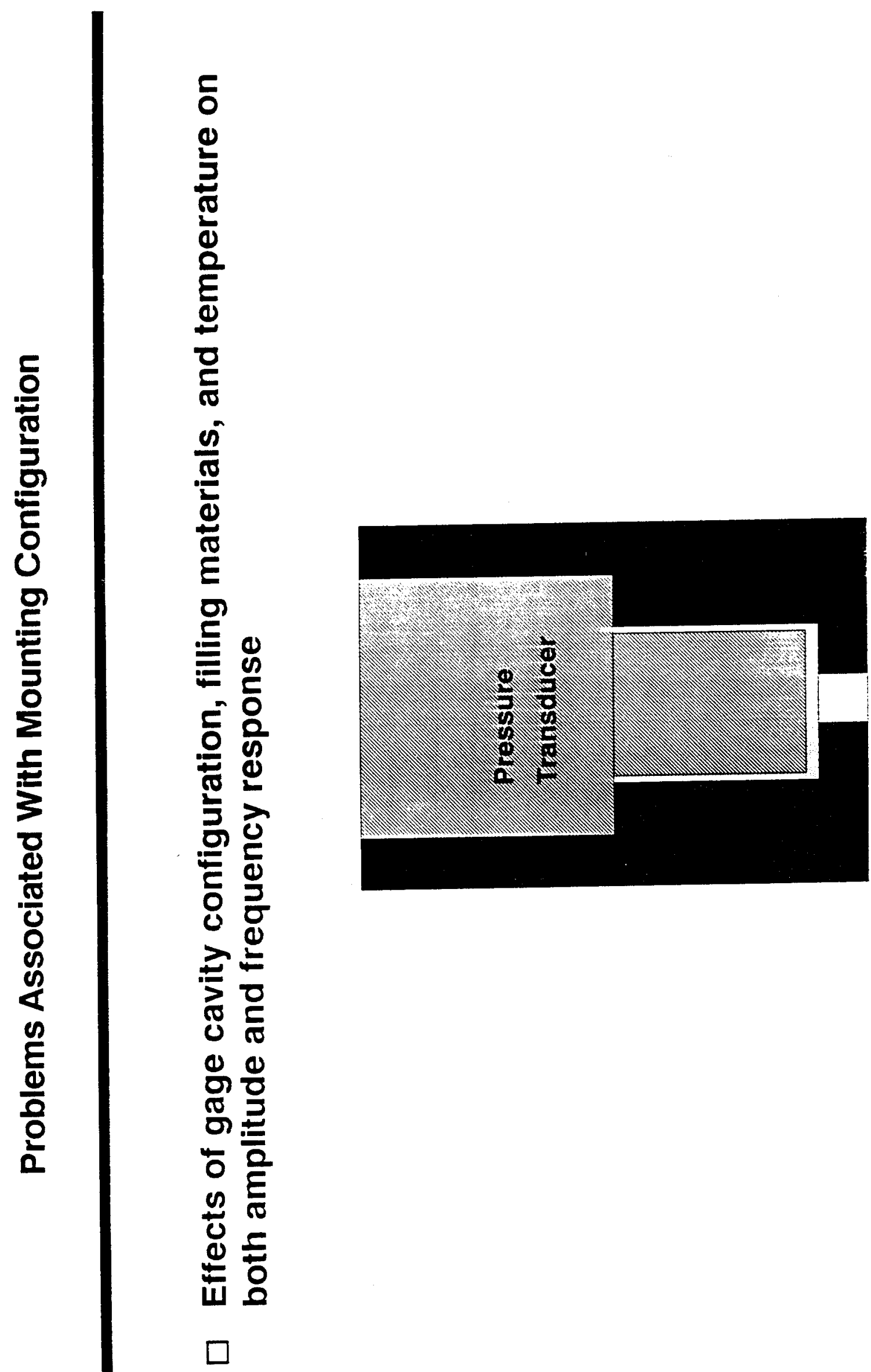

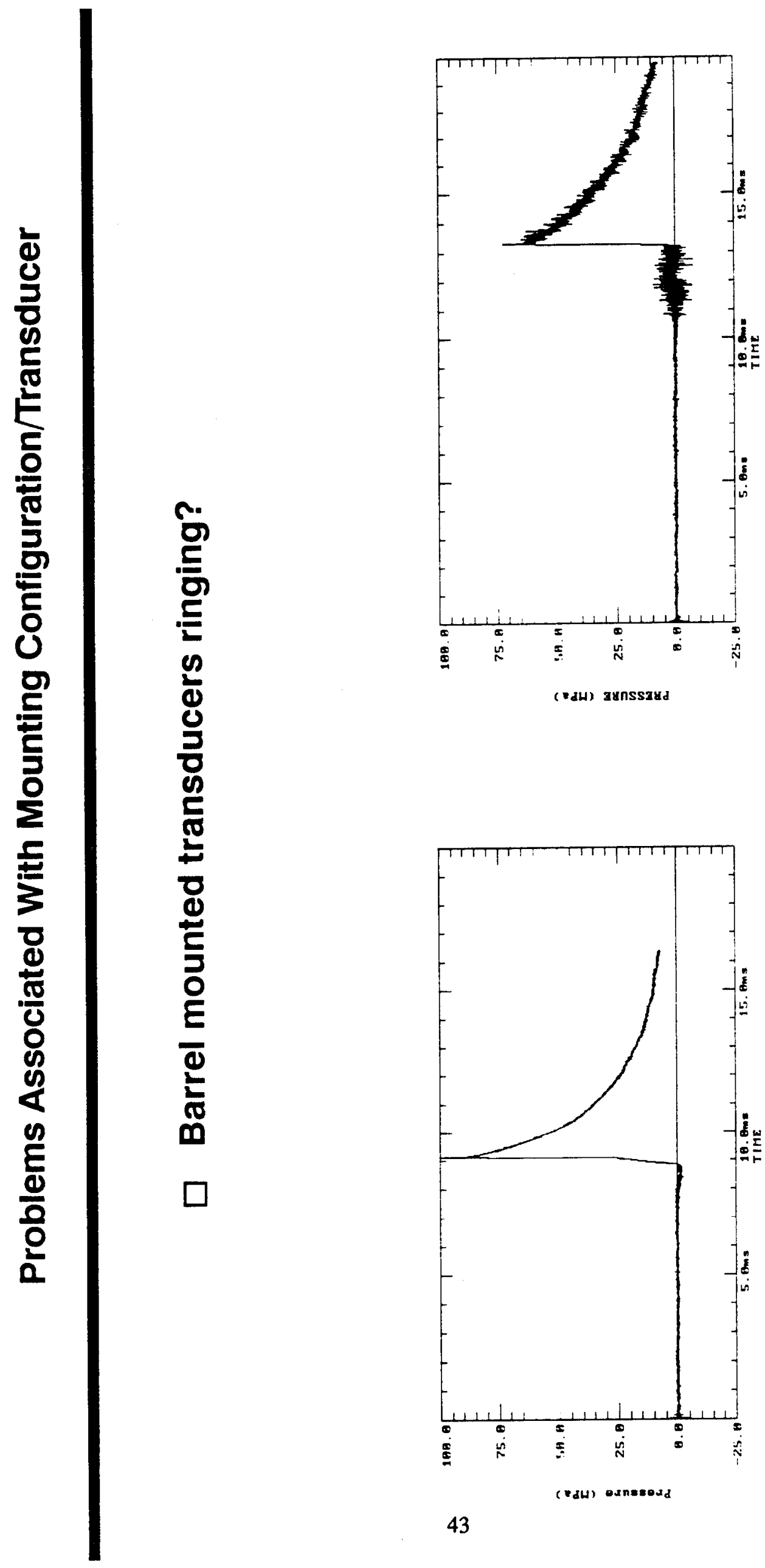


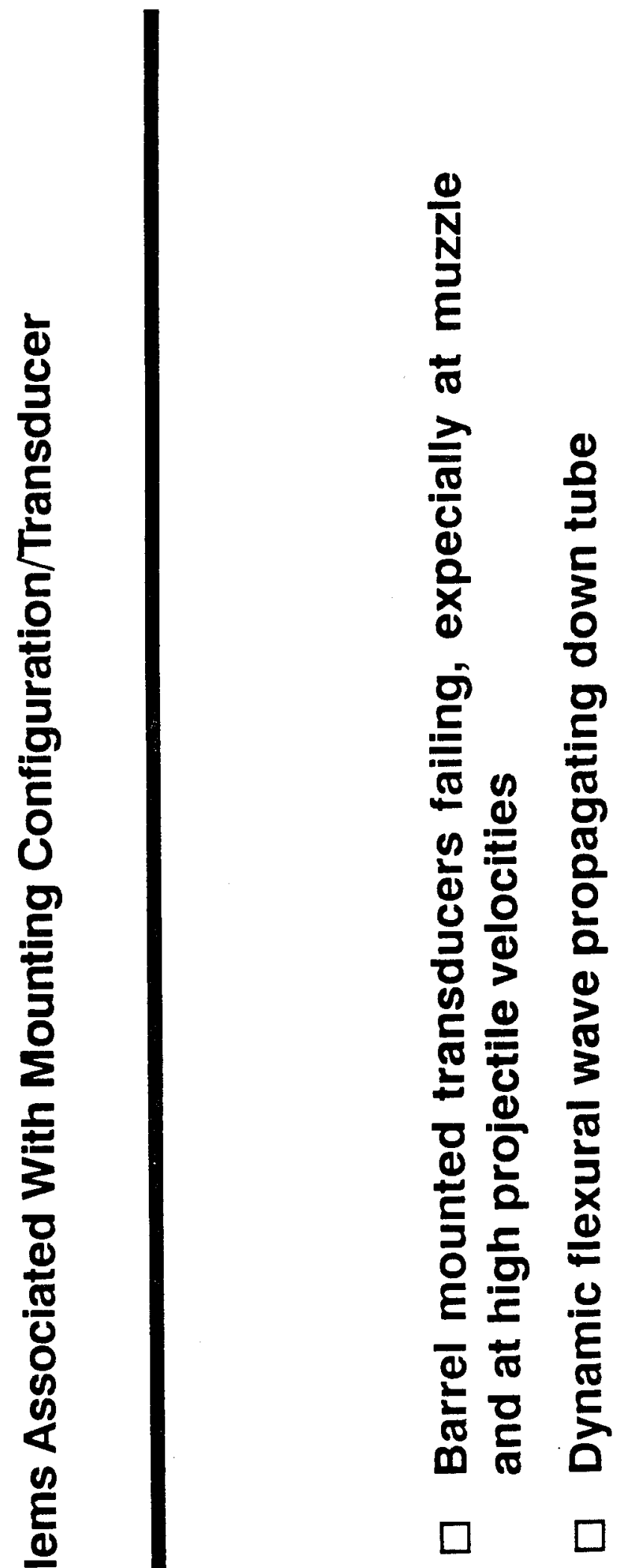



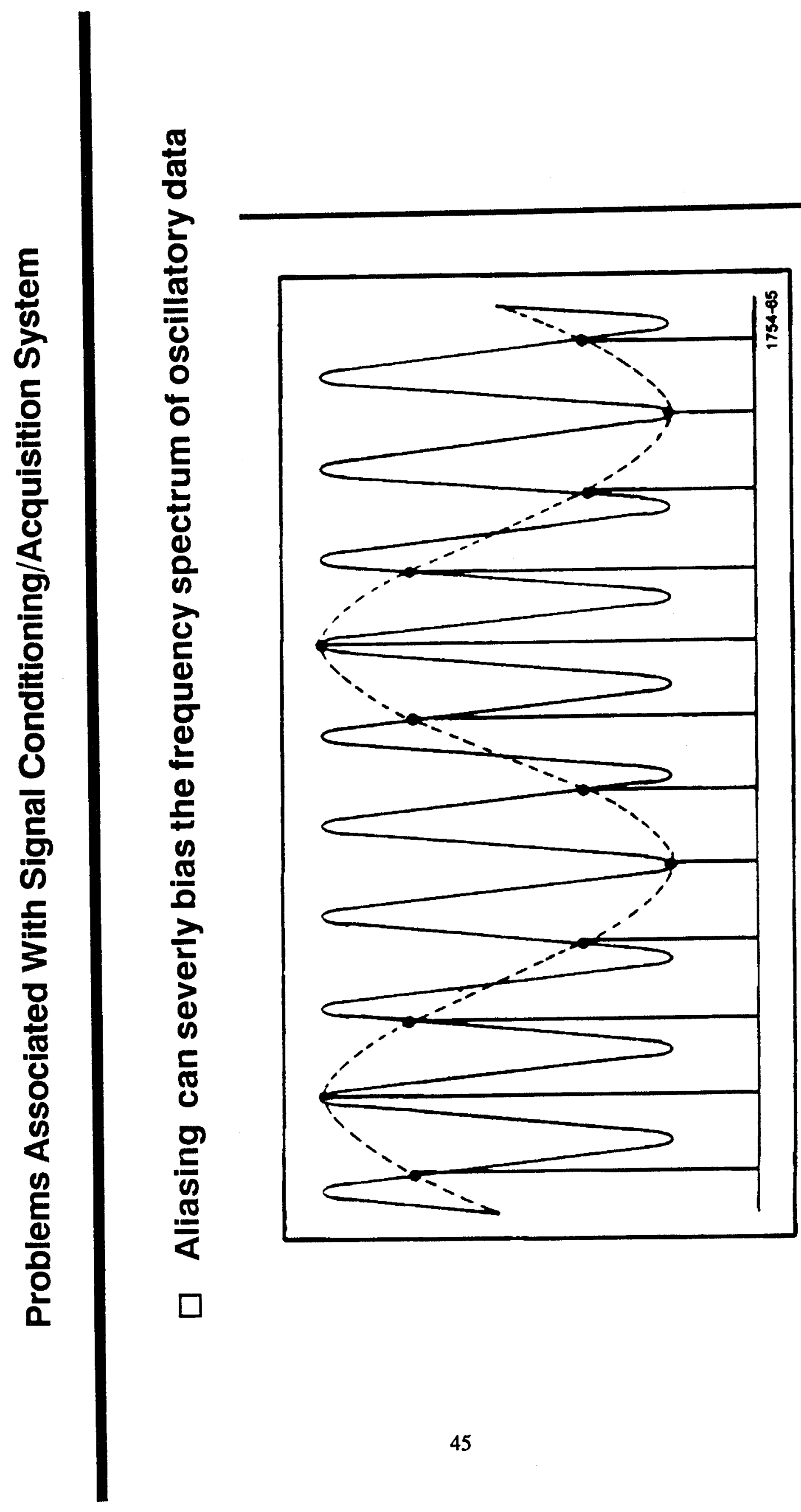


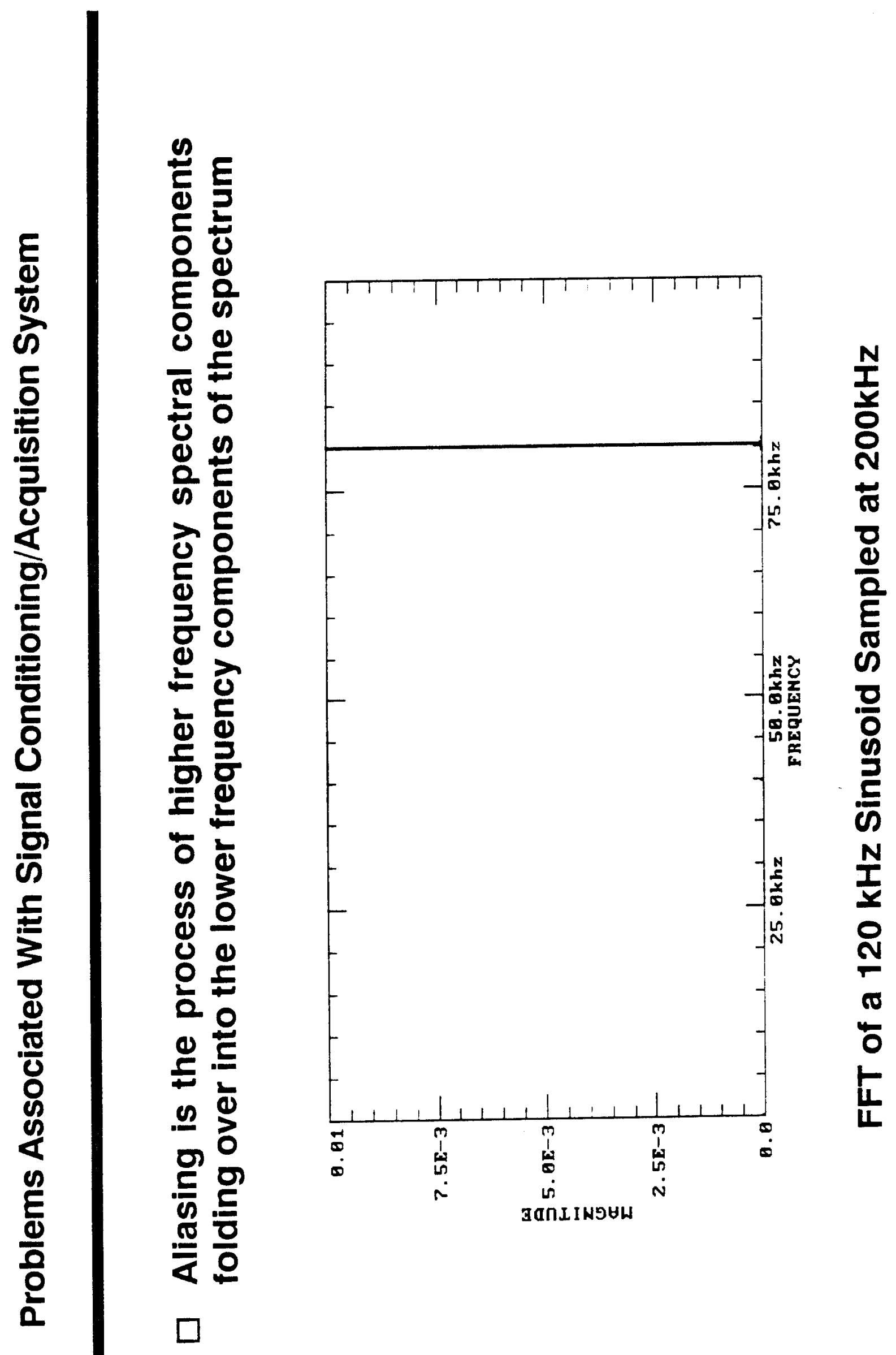



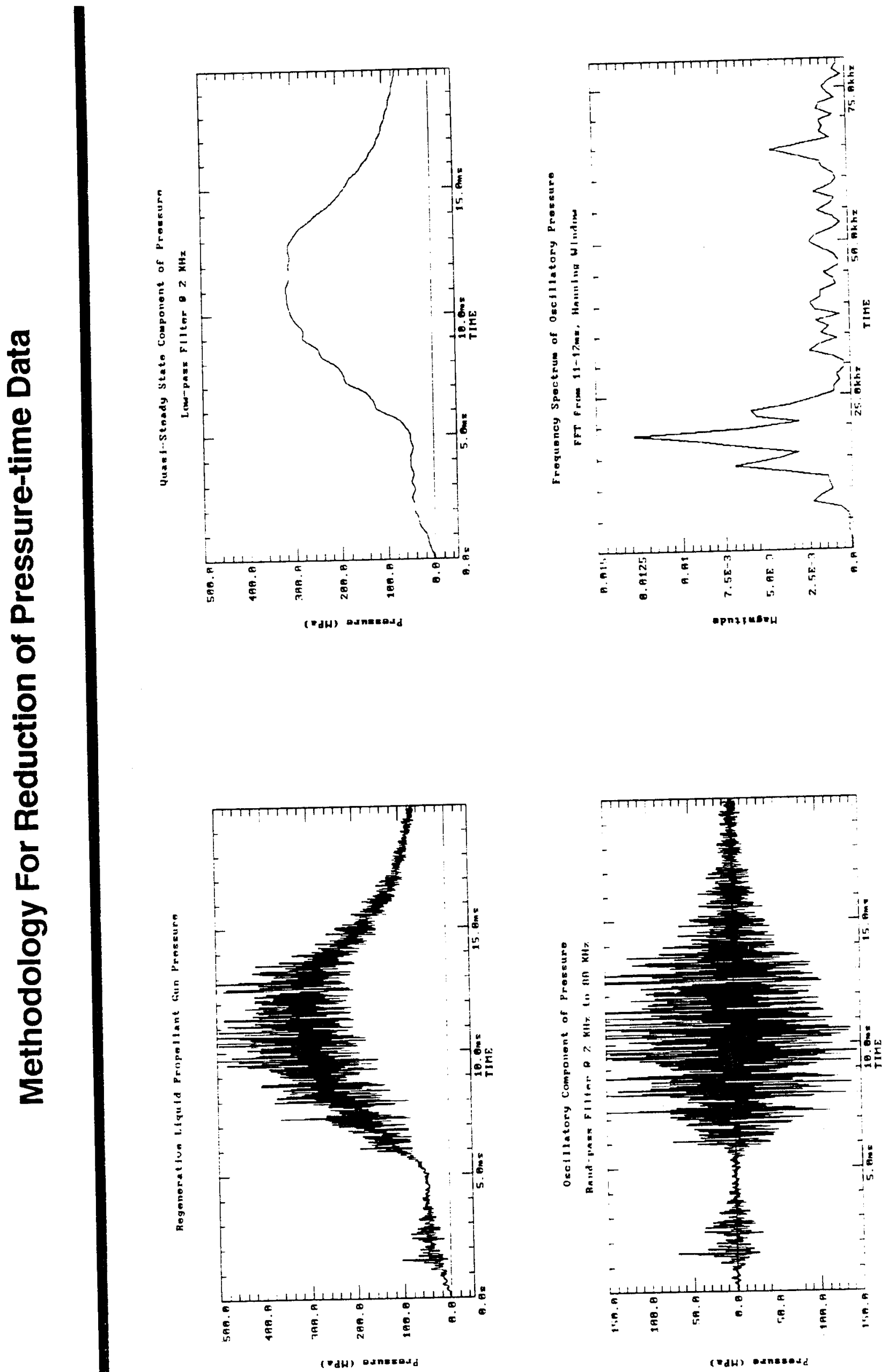

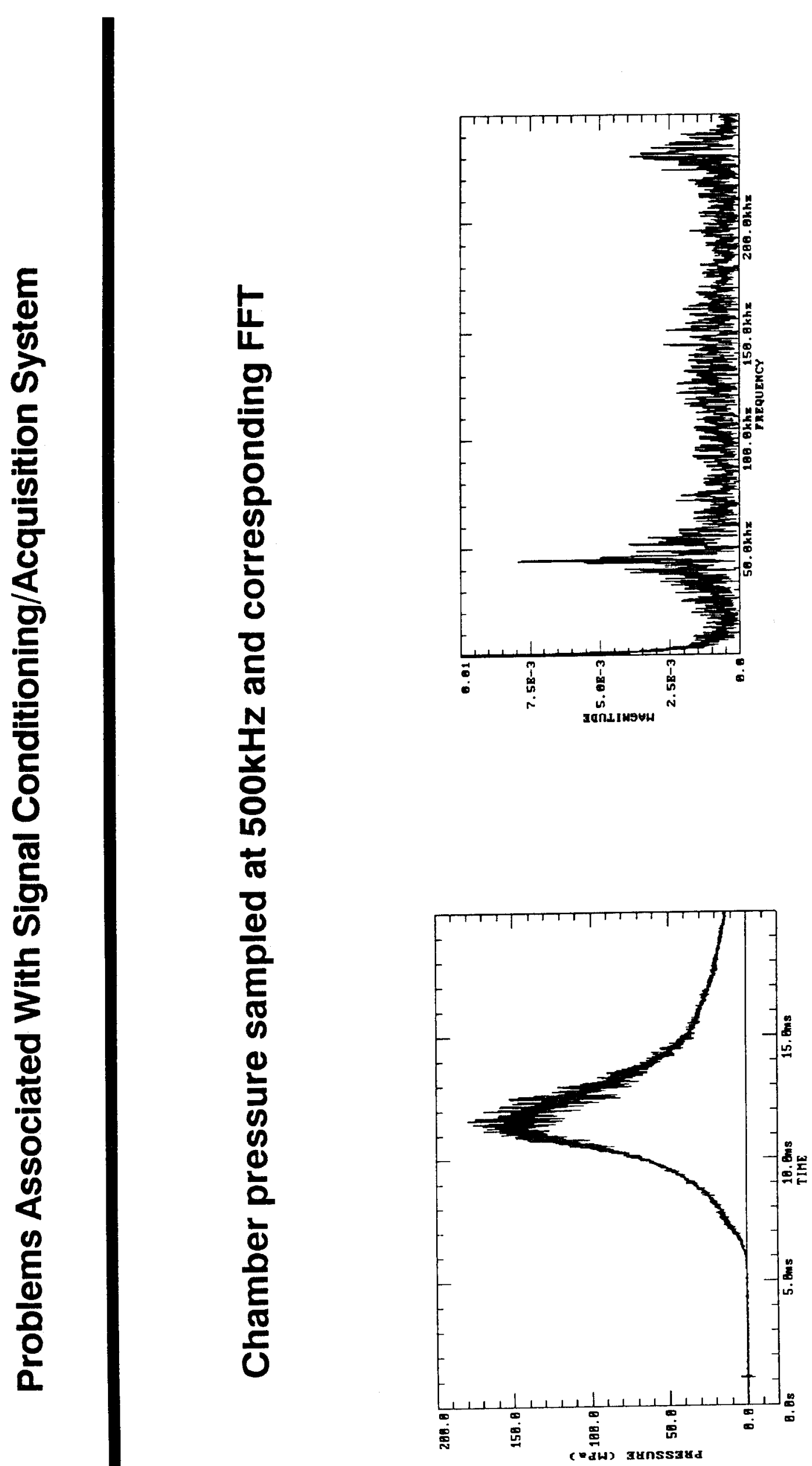


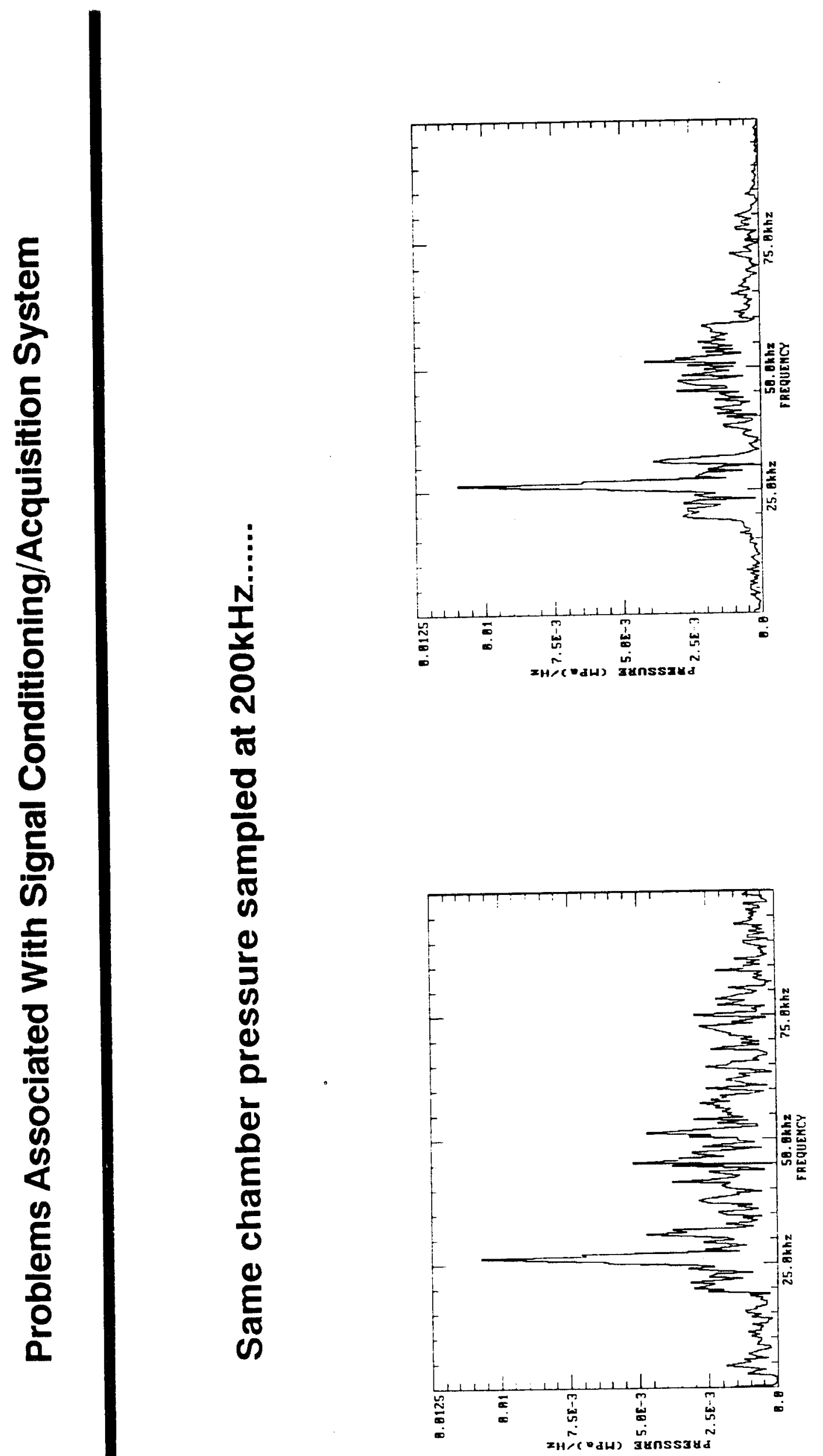

$\frac{\widehat{N}}{x}$

요

(C)

ㄹ

(1)

$\pm$

or

$\frac{E}{9}$

.

$\frac{1}{10}$
$\frac{1}{6}$
$\frac{5}{6}$
$\frac{5}{3}$
$\vdots$
$\vdots$

(1) 


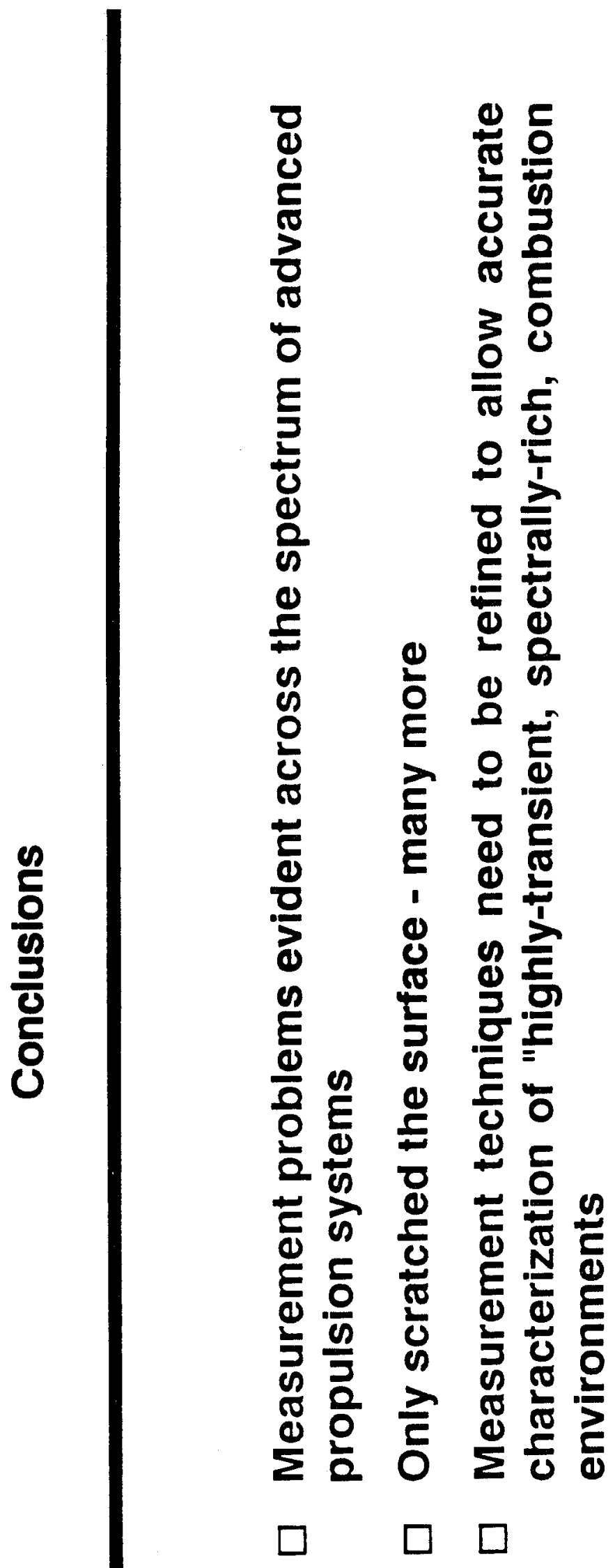


APPENDIX B:

PRESENTATION - "COMPARISON OF PRESSURE MEASUREMENTS IN THROUGH PORTS AND STEPPED PORTS"

This Appendix is presented in its original form without editorial changes or comments. 
INTENTIONALLY LEFT BLANK. 


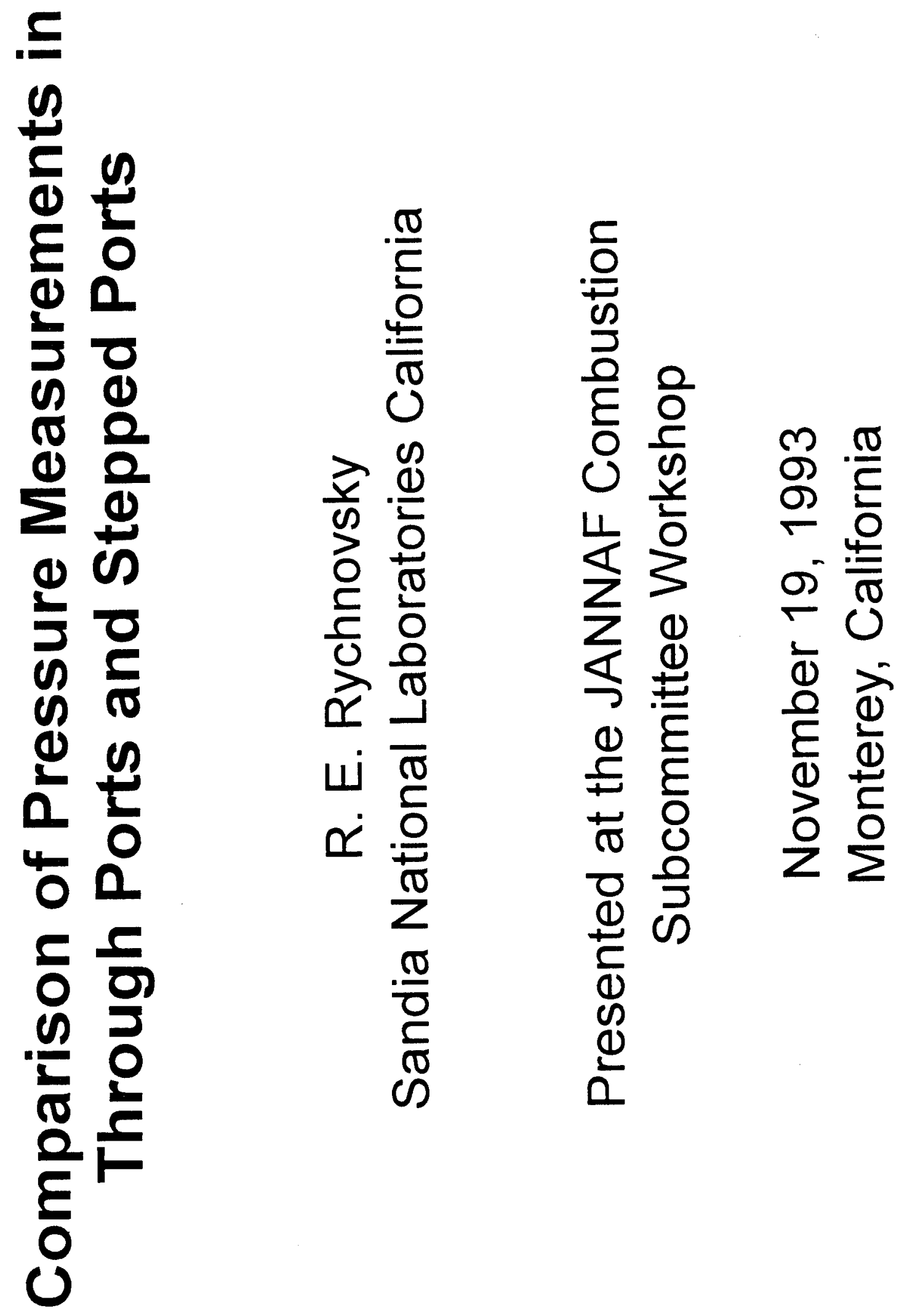


INTENTIONALLY LEFT BLANK.

54 


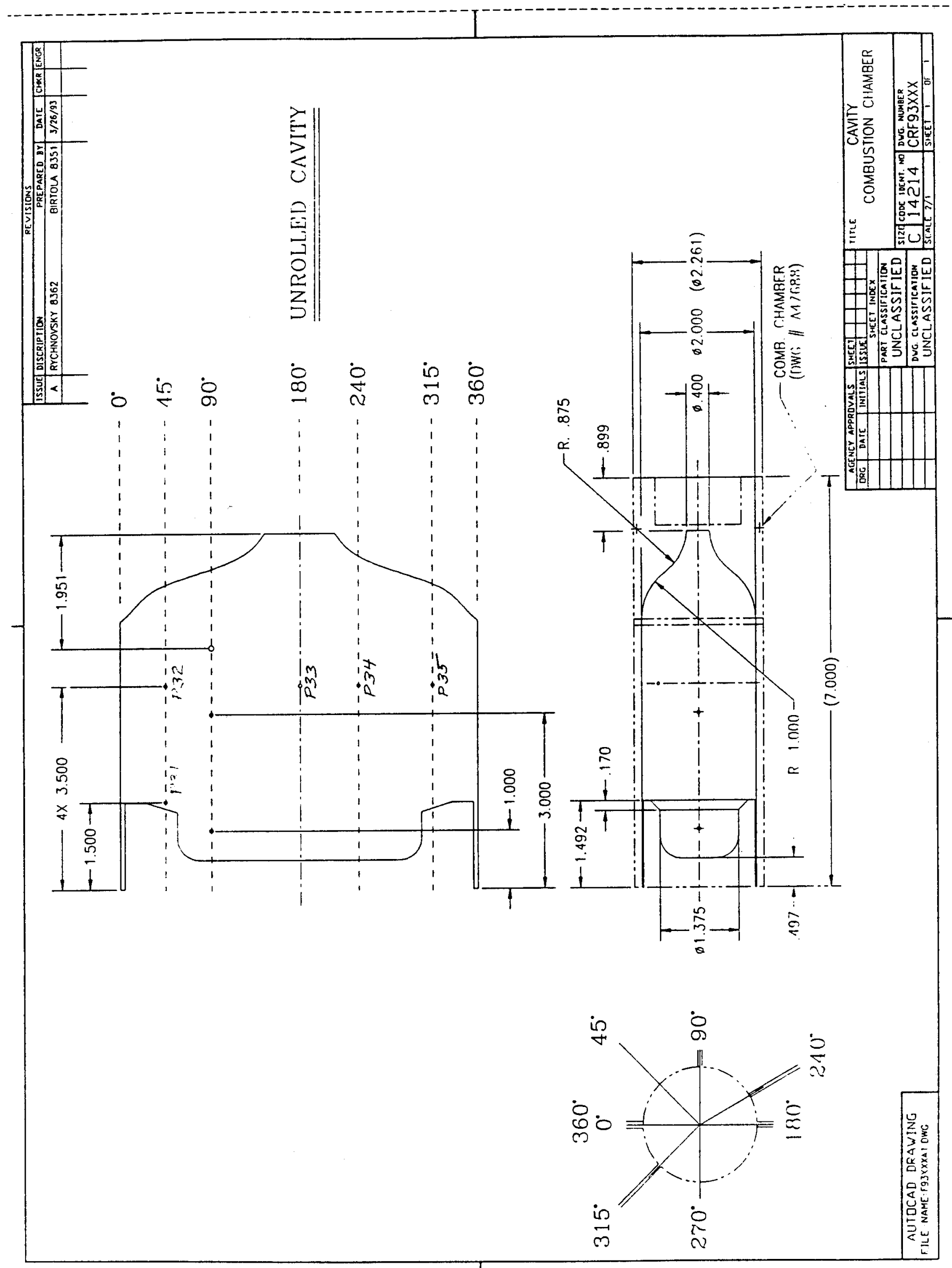




\section{Pressure Transducer Hole Inspection}

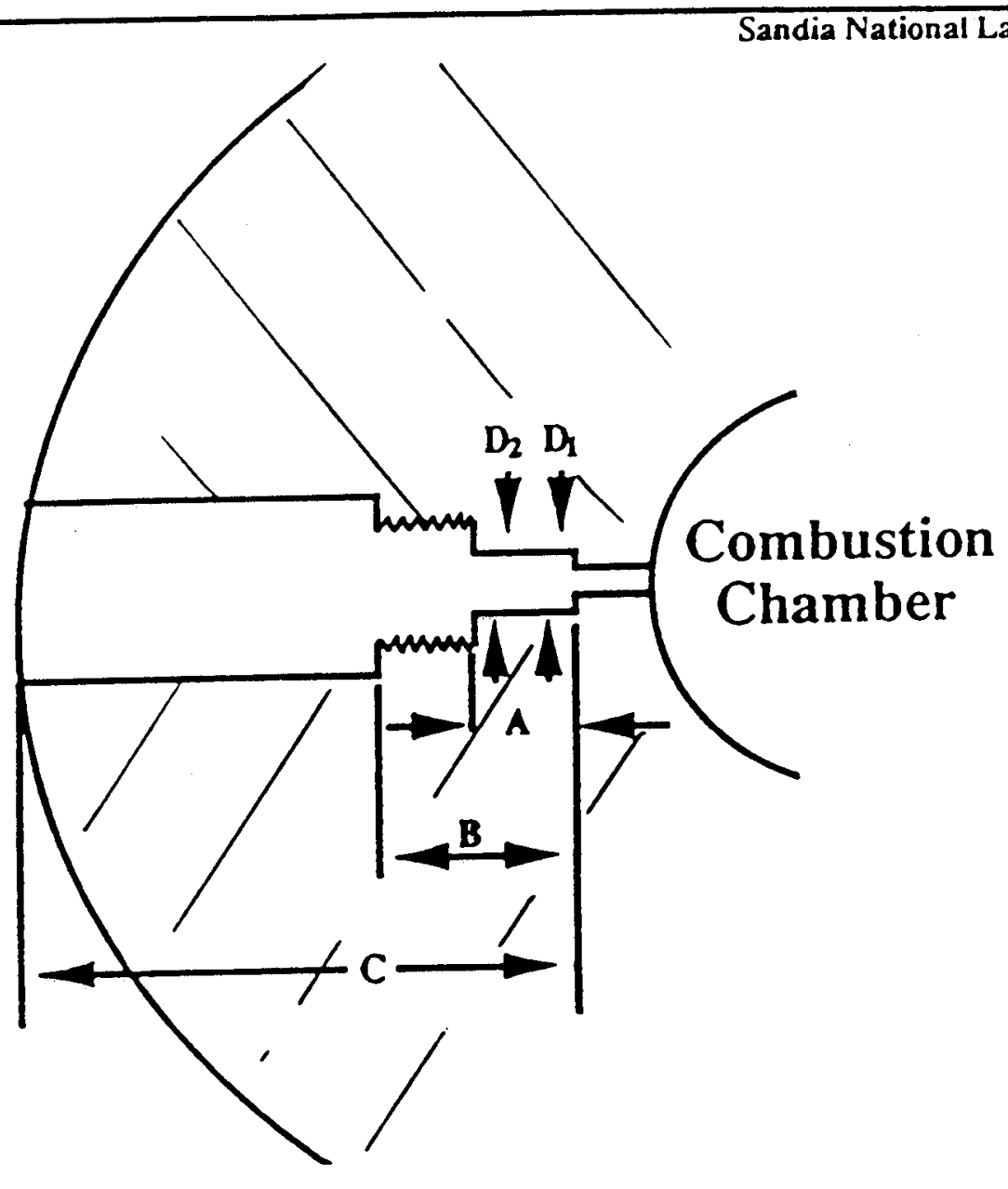

\begin{tabular}{|l|c|c|c|c|c|}
\hline Hole & $\mathrm{A}$ & $\mathrm{B}$ & $\mathrm{C}$ & $\mathrm{D}_{1}$ & $\mathrm{D}_{2}$ \\
\hline P35 & .263 & .747 & 2.888 & .252 & .252 \\
\hline P34 & .265 & .747 & 2.895 & .259 & .254 \\
\hline P33 & .265 & .747 & 2.871 & .277 & .252 \\
\hline P32 & .325 & .750 & 2.889 & .276 & .251 \\
\hline P31 & .277 & .752 & 2.874 & .260 & .260 \\
\hline
\end{tabular}

Tolerances: $A \rightarrow .260 \div .0000$

$\mathrm{B} \rightarrow .750: .005$

$\mathrm{C} \rightarrow 2.906 \div .0002$

$D_{1}$ and $D_{2} \rightarrow .250 \div .0100$ 


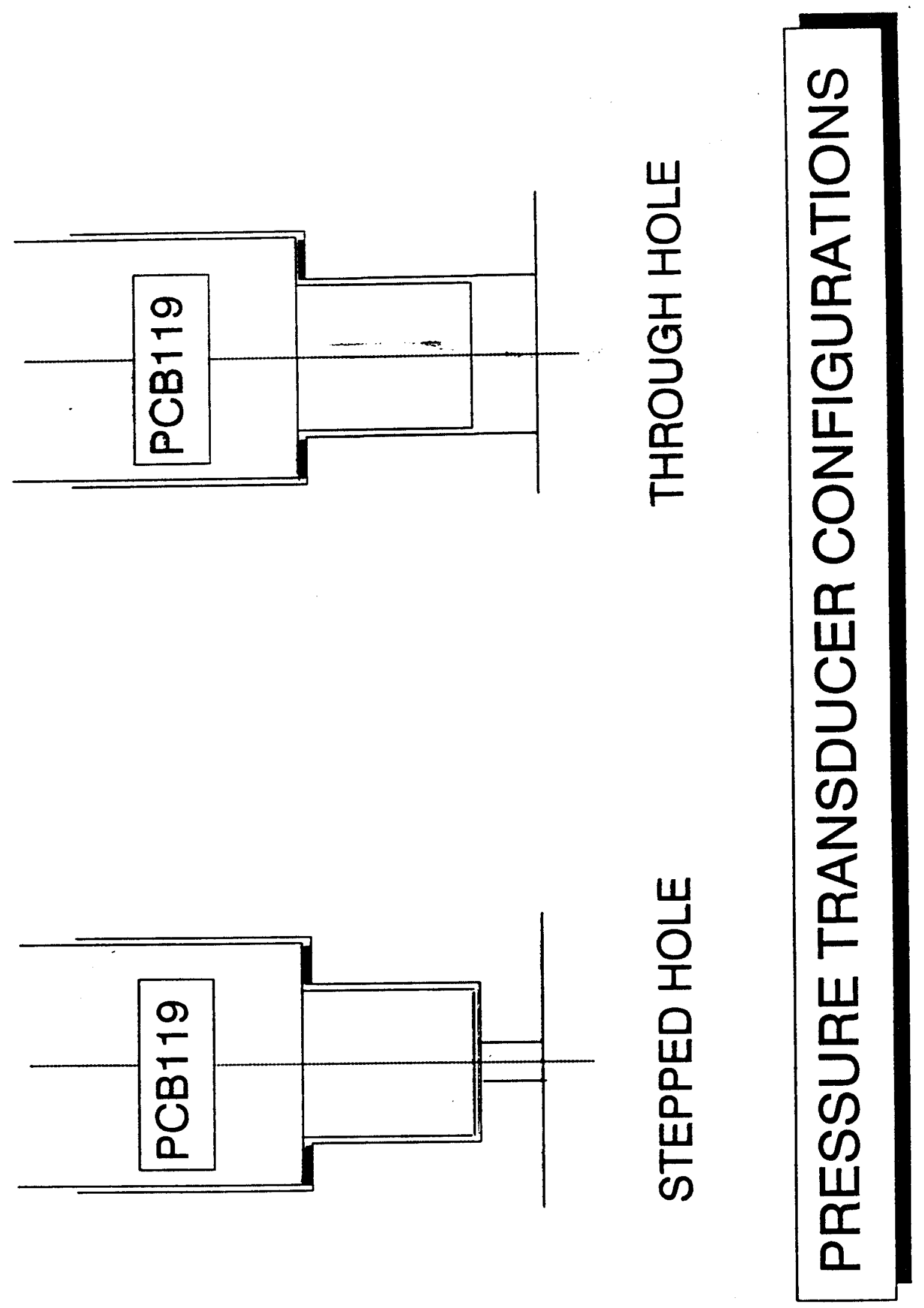




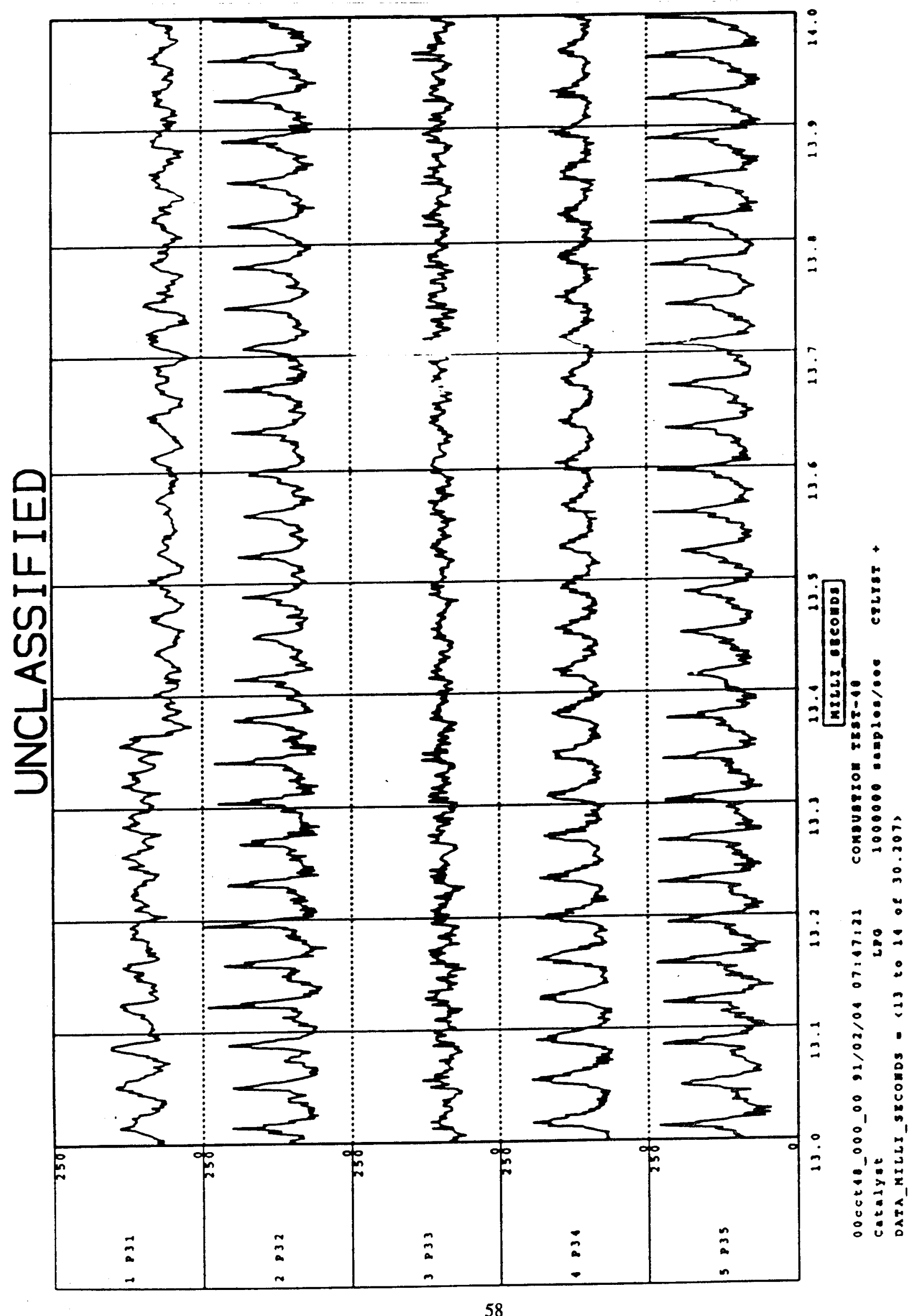




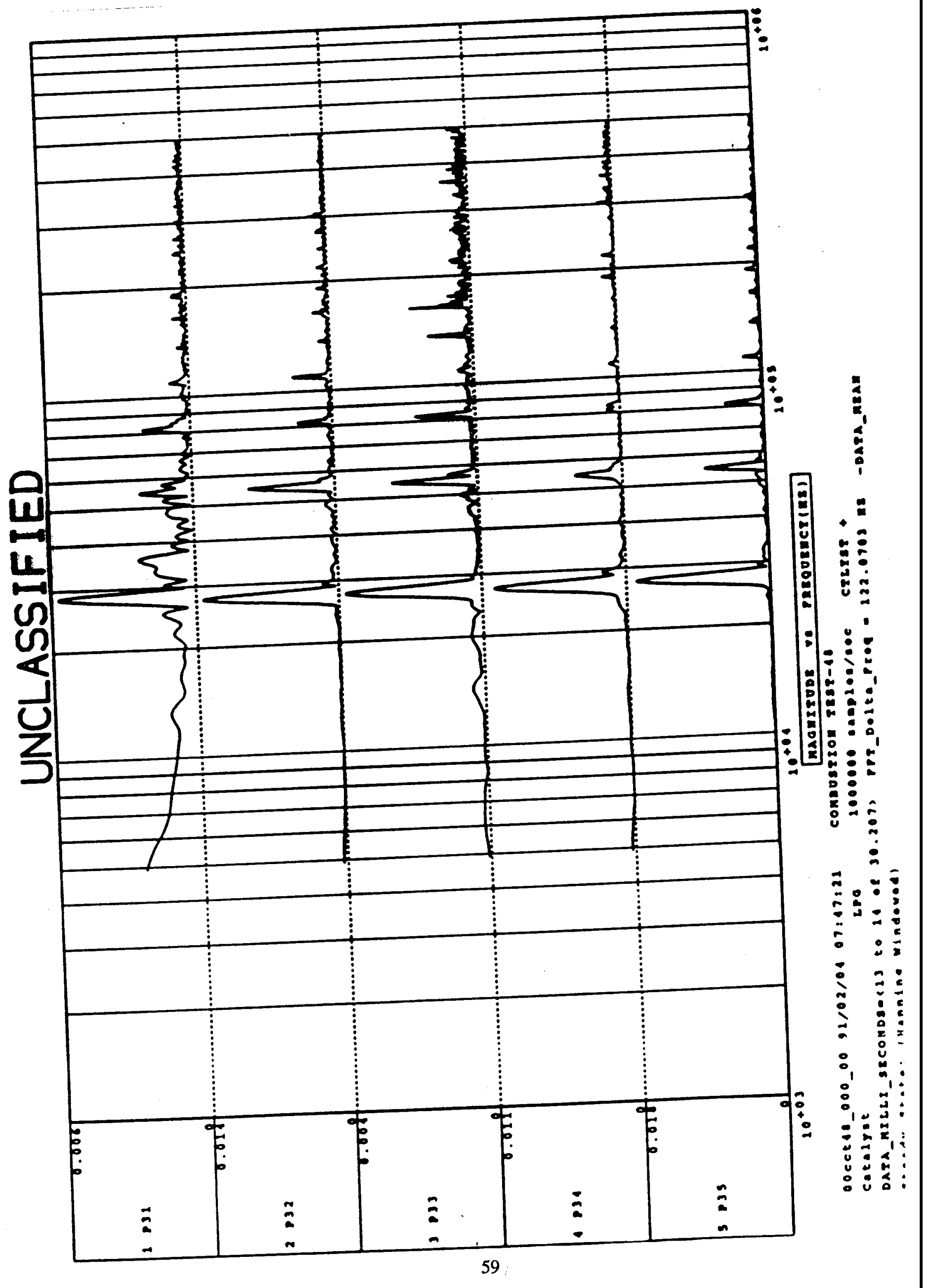




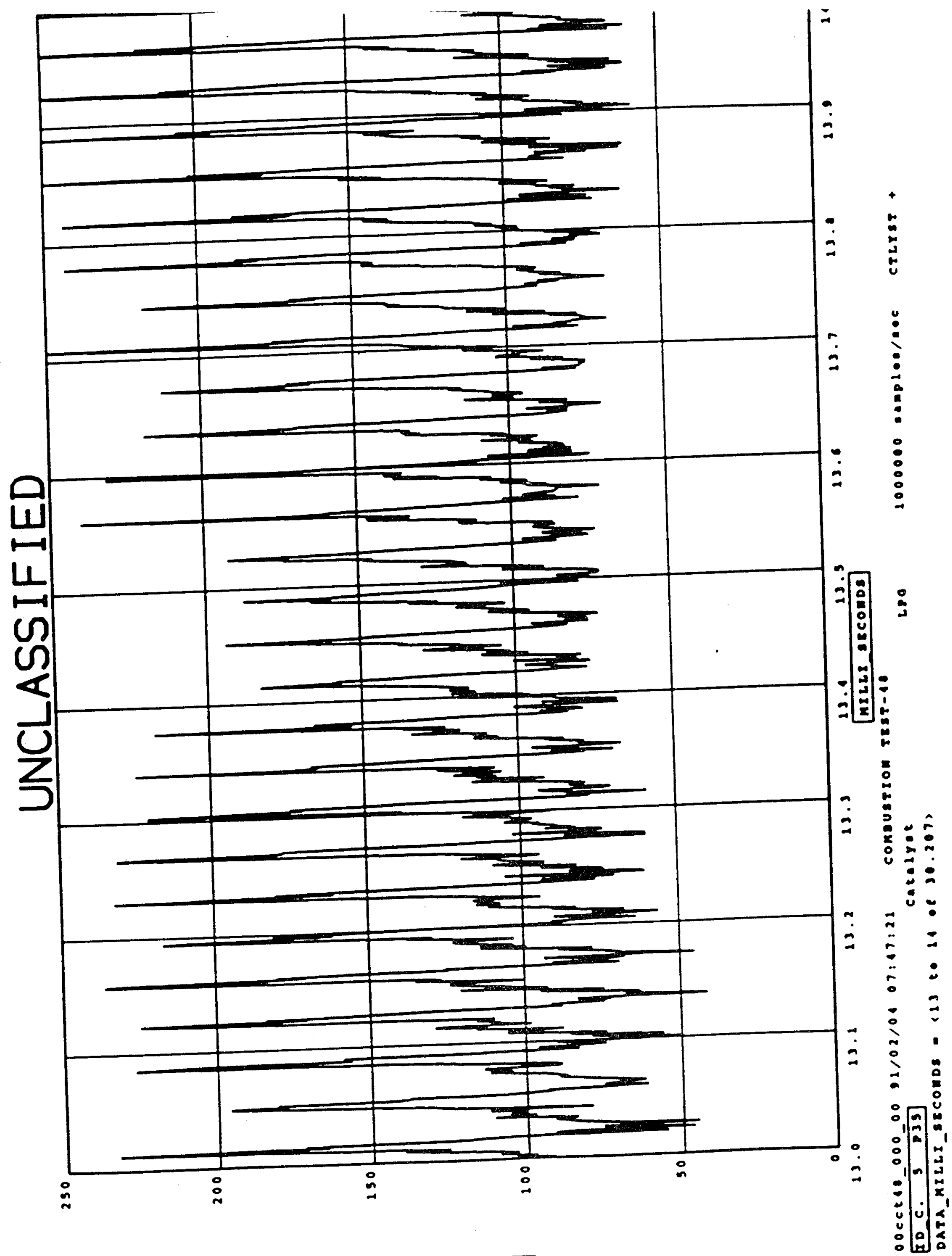

$\left(8 \angle 8 \varepsilon^{\prime} \theta+M H \partial+1\right)<--41 \% 0^{-}$MY YdA 


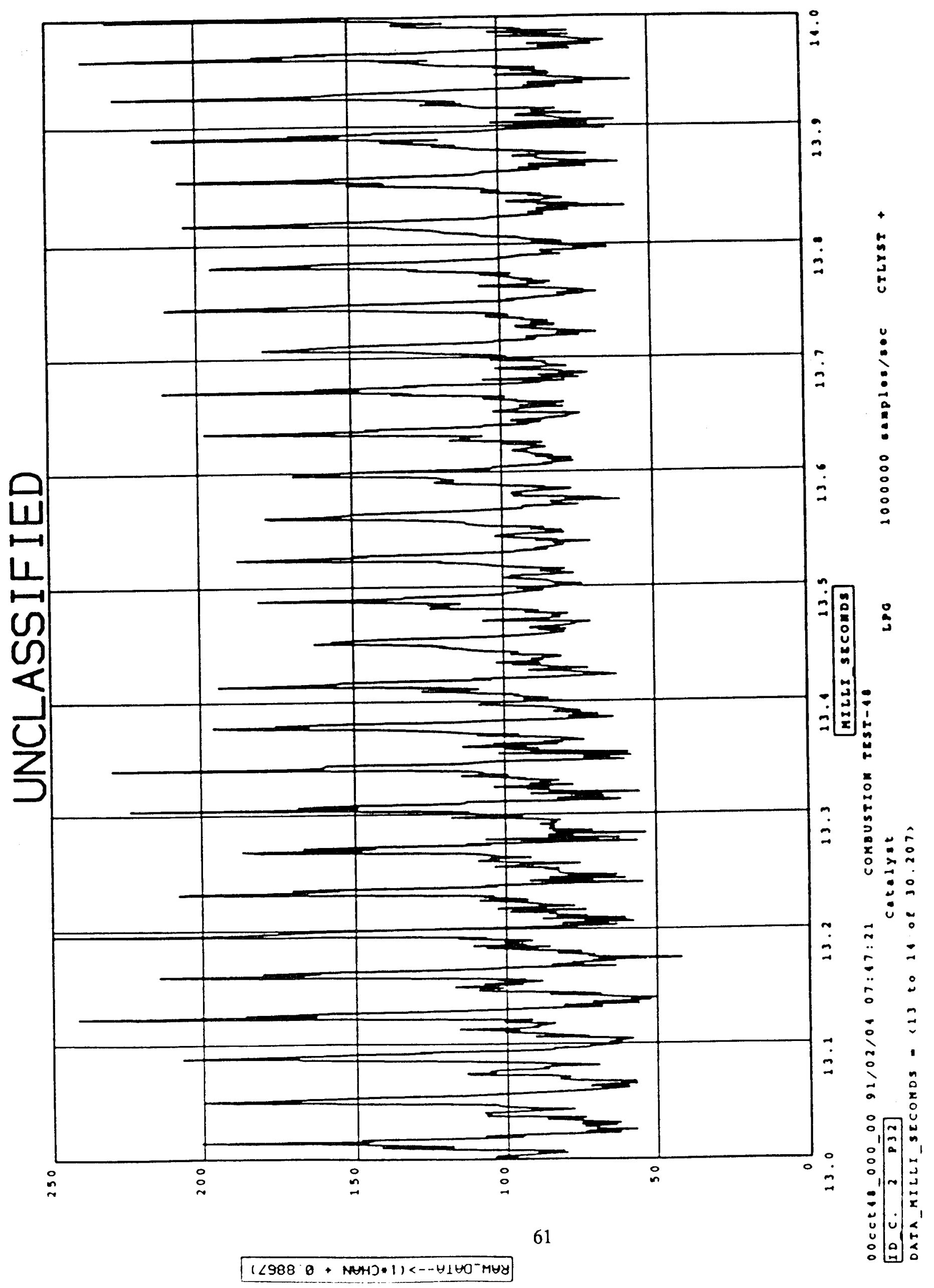




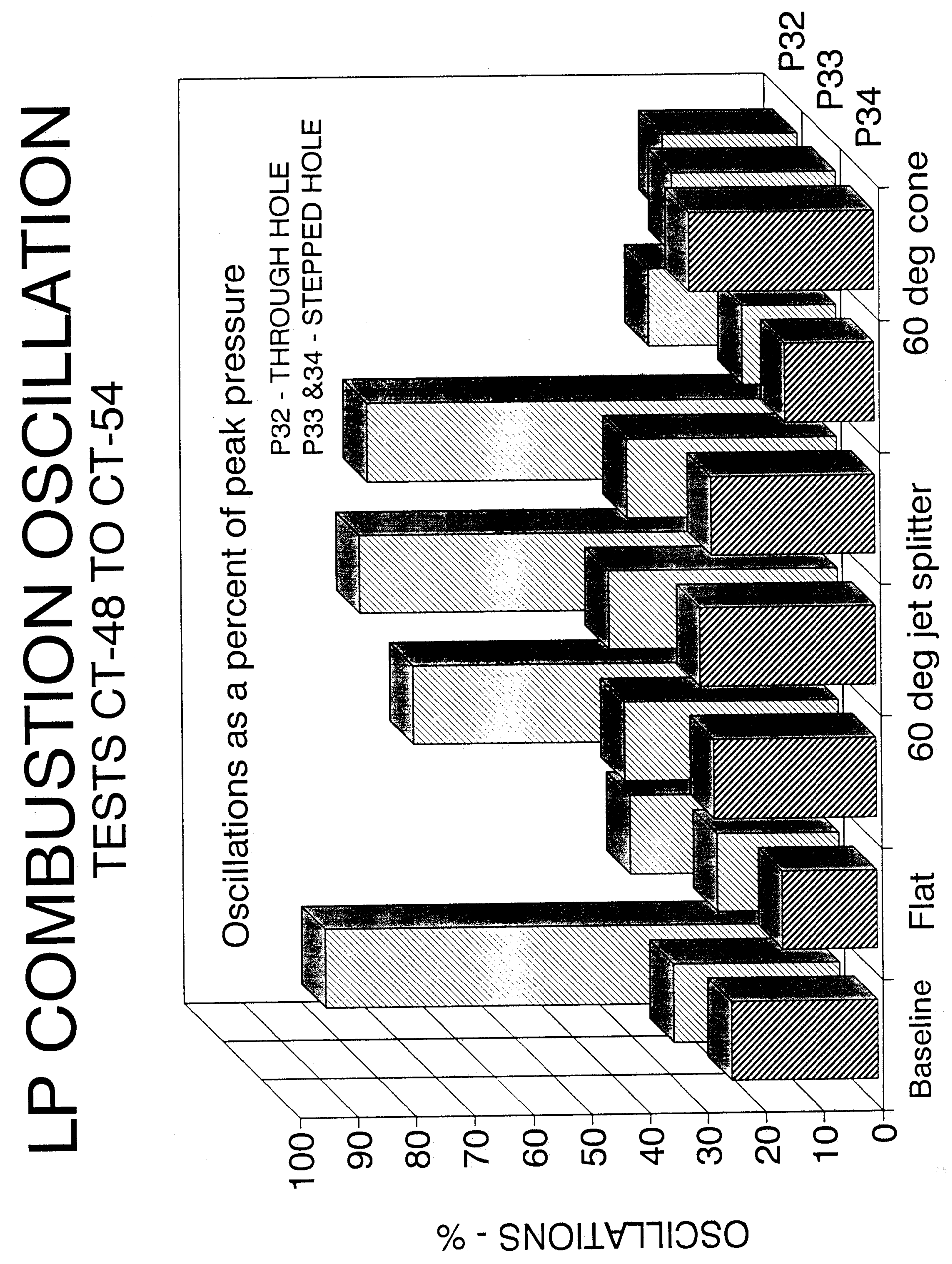




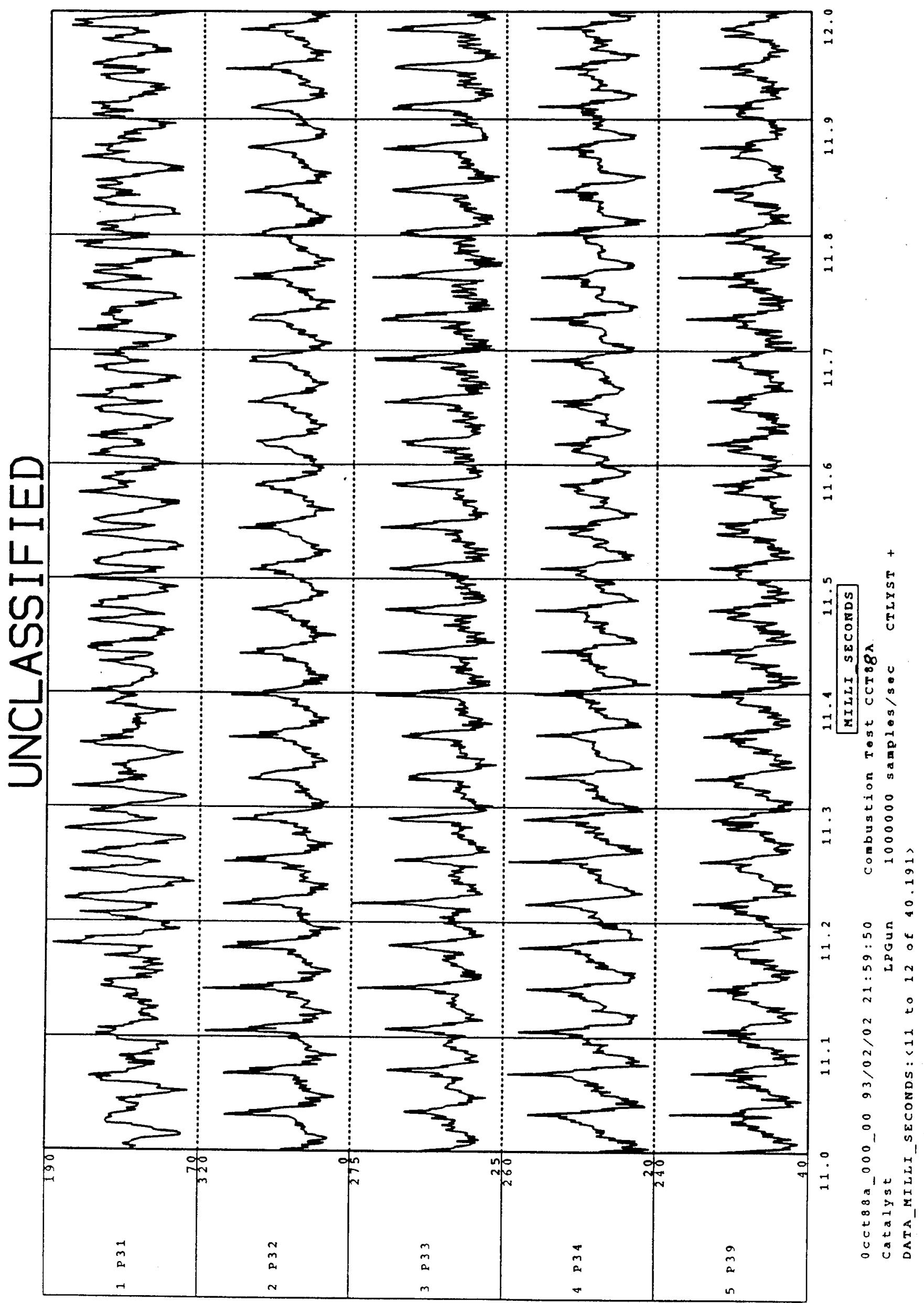




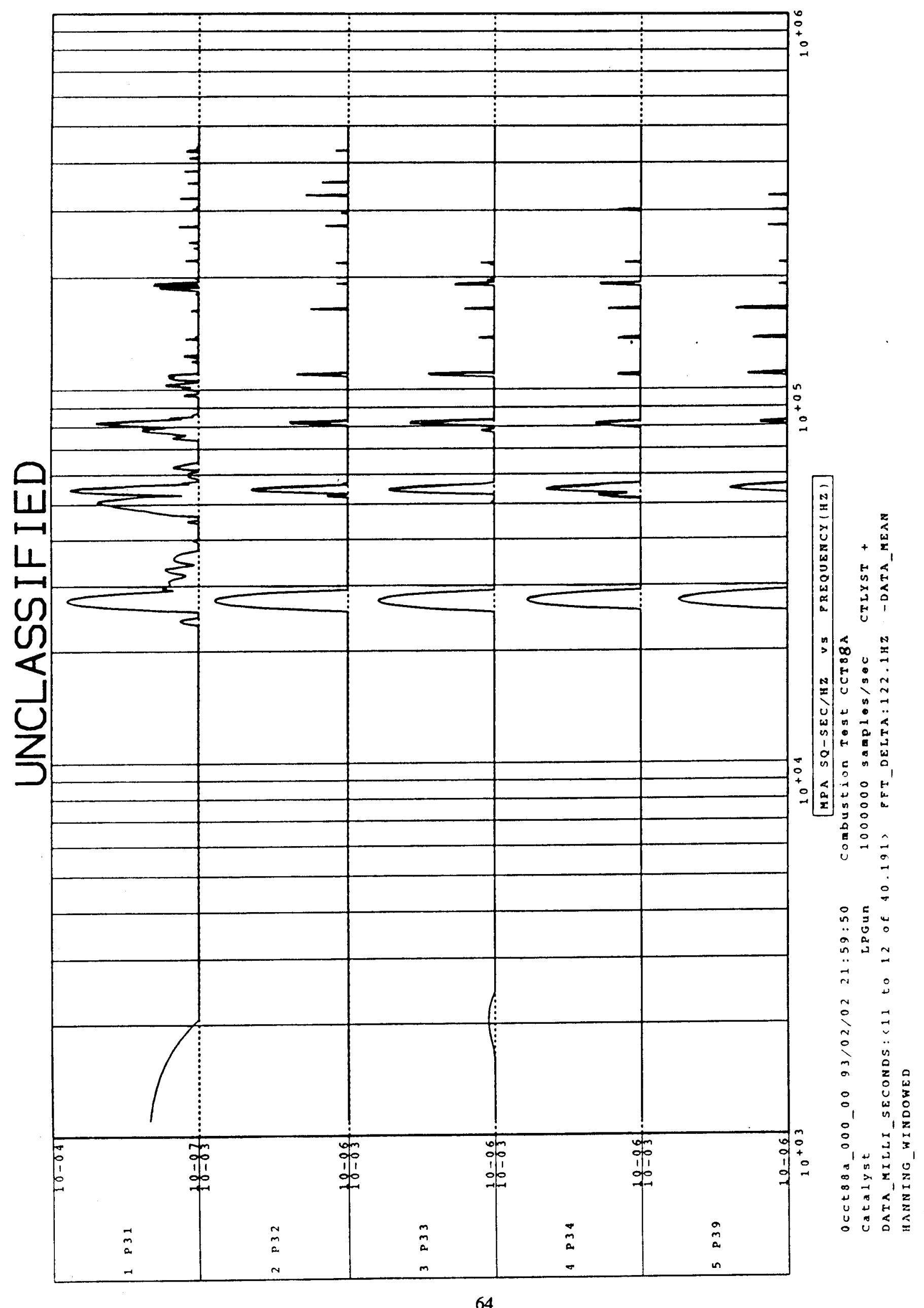




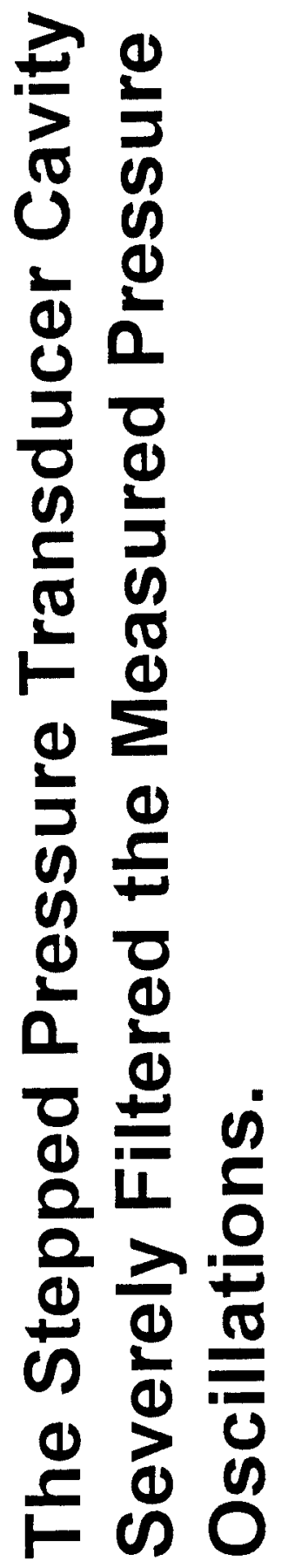


INTENTIONALLY LEFT BLANK. 
APPENDIX C:

PRESENTATION - "MEASUREMENT OF OSCILLATORY PRESSURE USING SINGLE DIAMETER AND TWO DIAMETER TRANSDUCER CAVITIES"

This Appendix is presented in its original form without editorial changes or comments. 
INTENTIONALLY LEFT BLANK.

68 


\title{
Measurement of Oscillatory Pressures Using Single Diameter and Two Diameter Transducer Cavities
}

\author{
G. A. Benedetti \\ Solid Mechanics Department \\ Sandia National Laboratories, California
}


INTENTIONALLY LEFT BLANK.

$\rightarrow$ 

Measurement of Oscillatory Pressures Using Single Diameter and Two Diameter
Transducer Cavities*

\author{
G. A. Benedetti \\ Solid Mechanics Department \\ Sandia National Laboratories/California
}

\begin{abstract}
Stepped-recessed pressure transducer cavities, which may be grease-filled, are suitable for measuring quasi-static pressure in solid propellant guns and regenerative liquid propellant guns, provided the frequencies contained in the quasi-static pressure pulse are low relative to the fundamental frequency for the empty stepped cavity.

Accurately measured oscillatory pressure-time histories are required to determine the dynamic structural response for projectiles (as well as for guns) and to assess their structural integrity with respect to oscillatory pressure environments in regenerative liquid propellant guns. Unfortunately, grease-filled two diameter cavities or steppedrecessed ports, which have a low fundamental frequency relative to most of the measured frequencies contained in the oscillatory pressures, have been used to measure oscillatory pressures in regenerative liquid propellant guns for many years, and this has resulted in an inaccurate oscillatory pressure data base over a large region of the frequency range of interest. Analysis and laboratory experiments both confirm this. Further, the issue of using grease-filled stepped-recessed transducer ports versus grease-filled through-hole transducer ports to measure oscillatory pressures has been ongoing for more than two years. There is ample data which shows that grease-filled stepped-recessed cavities are not suitable for measuring oscillatory pressures over a large region of the frequency range of interest. Therefore, it is strongly recommended that this issue be resolved so that the structural integrity of projectiles in the inventory can be accurately assessed when subjected to the oscillatory pressure environment associated with RLPGs.
\end{abstract}

*This work was sponsord in part by the Project Manager's Office, Advanced Field Artillery Systems, Picatinny Arsenal. 


\section{REQUIREMENT}

- Measurement system requires a flat or one-toone response (e.g., $p_{\text {out }} / p_{\text {in }}=1.0$ ) over range of frequencies of interest associated with input signal, $\mathrm{p}_{\text {in }}$.

- This implies that the cavity natural frequency is significantly higher than the highest frequency of interest in the input signal.

e.g., $f_{\text {nat cavity }} \geq 5 f_{\text {input signal }}$ 


\section{Oscillatory Pressure Measurements}

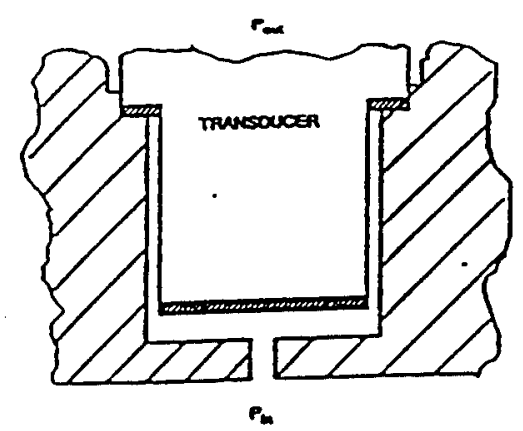

Pressure Transducer and Cavity

Steady State Pressure Response Spectrum for Transducer Cavity
Pout

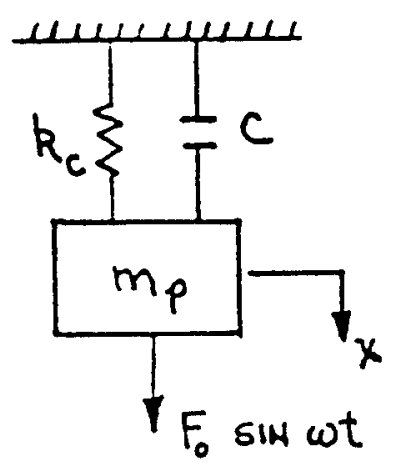

$P_{\text {in }}$

$\ddot{x}+2 \zeta \omega_{n} \dot{x}+\omega_{n}^{2} x=\frac{F_{0}}{m_{p}} \sin \omega t$

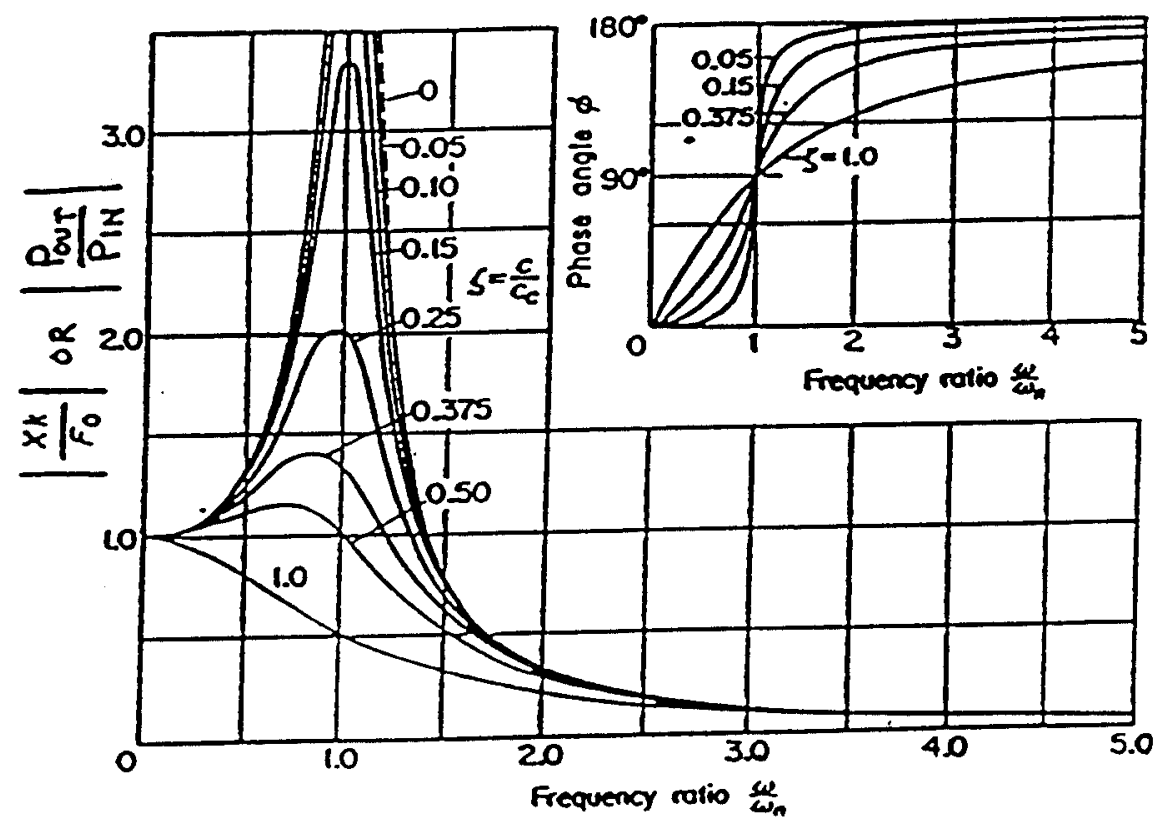

Dynamic amplification factor for transducer cavity as a function of frequency ratio and damping factor. $\omega$ is the frequency of pressure oscillation (input frequency) at the gun tube wall and $\omega_{n}$ is the first undamped natural circular frequency for the cavity. The phase angle is the angle between the input and output pressures where $P_{\text {out }}$ lags $P_{\text {in }}$ by the angle $\phi$. 


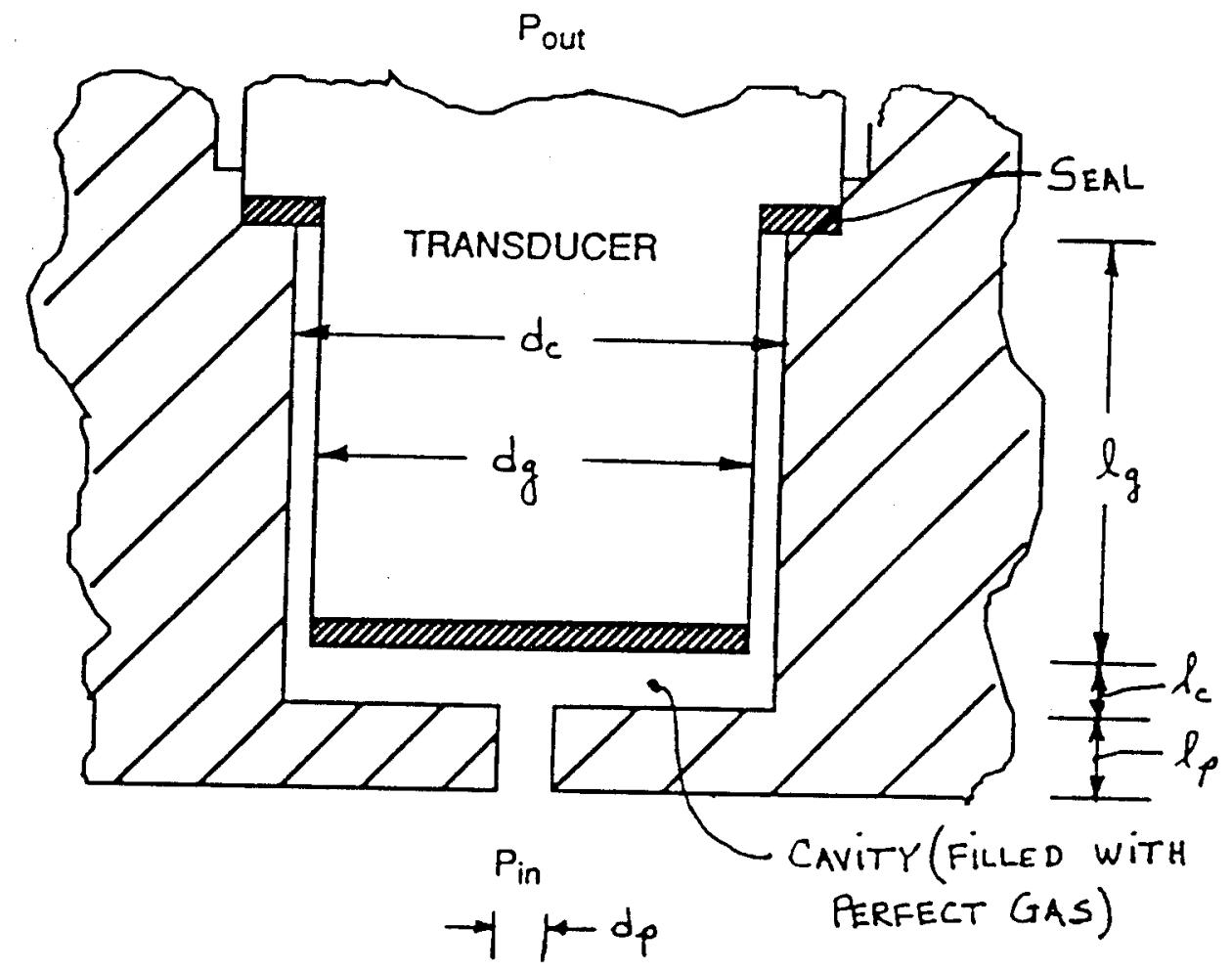

Figure 22. Transducer cavity or stepped-recessed port. Note that the cavity dimensions can vary due to tolerances, machining errors, and installation procedures.

$$
f_{n}=\frac{c_{o}}{2 \pi} \sqrt{\frac{\mathrm{A}_{p}}{V_{c} \ell_{p}}}
$$

where

$$
\begin{aligned}
& A_{p}=\pi d_{p}^{2} / 4 \\
& V_{c}=\pi d_{c}^{2} \ell_{c} / 4+\pi\left(d_{c}^{2}-d_{s}^{2}\right) \ell_{s} / 4 \\
& c_{o}=\text { local sound speed } \\
& f_{n}=\text { first undamped natural frequency (in hertz) }
\end{aligned}
$$

$$
\text { * Single? iampier tivety in }=\frac{C_{0}}{4 \mu p}
$$




\section{Times for a Damped Linear Oscillator to Reach Steady State Vibration}

\begin{tabular}{ccc}
$\begin{array}{c}\text { Natural } \\
\begin{array}{c}\text { Frequency } \\
(\mathrm{kHz})\end{array}\end{array}$ & $\begin{array}{c}\text { Natural } \\
\text { Period } T_{n} \\
\text { (Millisec) }\end{array}$ & $\begin{array}{c}\text { Time } t_{S s} \cong T_{n} / 2 \zeta_{n} \\
\text { to Reach Steady } \\
\text { State for } \zeta_{n}=3 \% \\
\text { (Millisec) }\end{array}$ \\
\hline & & \\
1 & 1.0 & 16.67 \\
2 & 0.5 & 8.33 \\
4 & 0.25 & 4.17 \\
6 & 0.167 & 2.78 \\
8 & 0.125 & 2.08 \\
16 & 0.063 & 1.05 \\
24 & 0.042 & 0.70
\end{tabular}




\section{ACOUSTIC MEASUREMENTS}

- CAVITIES NOT FILLED WITH GREASE

- THEORY VERSUS EXPERIMENT 
Run 1 Resonator, Solid=Test Data, Dotted=SDOF Model

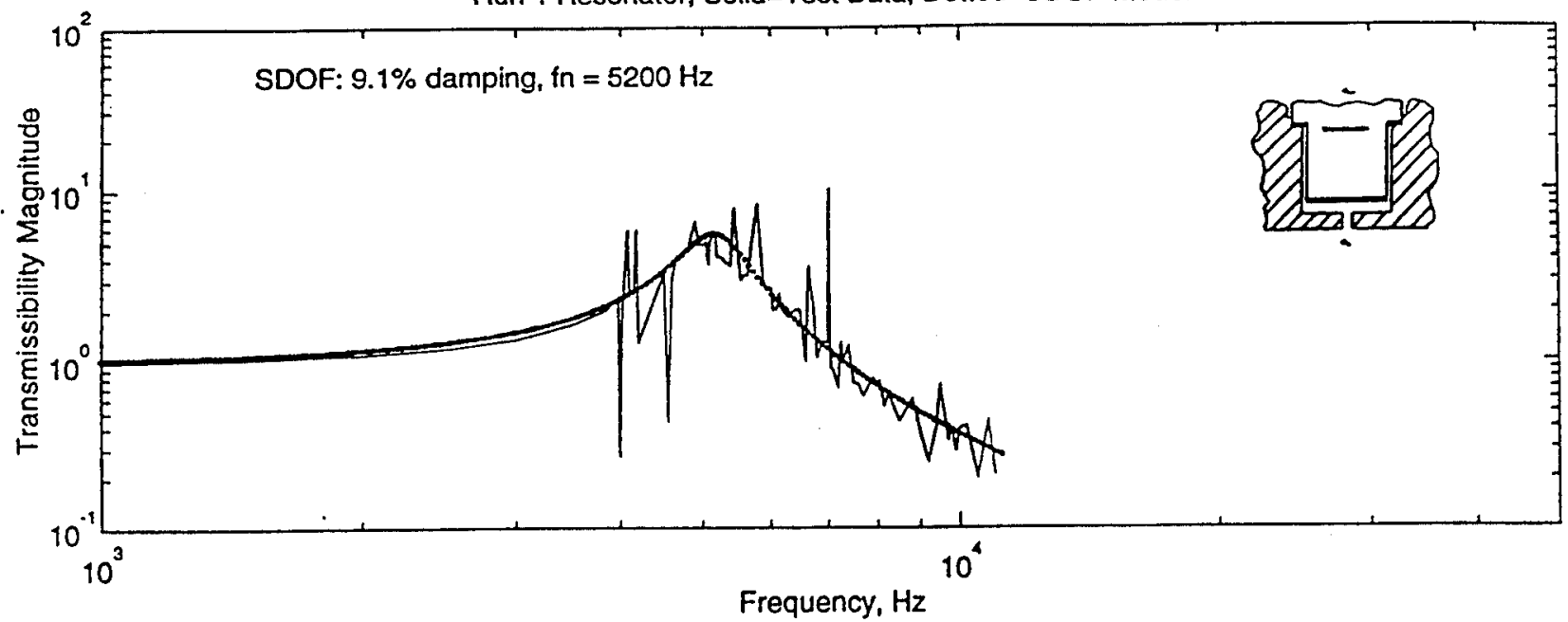

Figure 25. Acoustic pressure-frequency response spectrum for a two-diameter or stepped-recessed cavity. Solid line, measured data; dashed line, analytical or predicted data using Eq. (94). The spikes in the measured data result from reflections of the sound wave within the tube, e.g., at $4 \mathrm{kHz}$ the wavelength is $3.4 \mathrm{in}$. and the circumferential distance between transducers at the same axial location is 1.7 in.; the internal tube diameter is 2 in. and the tube length is $18 \mathrm{in}$. The intemal reflections begin to be significant when the wavelength of the sound wave approaches two times the tube diameter. The local speed of sound is $13,554 \mathrm{in} / \mathrm{sec}$. Cavity dimensions (refer to Figure 22) in inches are: $d_{p}=0.058, \ell_{p}=0.100, d_{z}=0.234, \ell_{s}=0.112, d_{c}=0.242, \ell_{c}=0.070$. The calculated and measured first natural frequencies for the cavity are 5,830 and $5,200 \mathrm{~Hz}$, respectively. It is suspected that the measured dimensions of the cavity are slightly in error and that the cavity volume is larger than calculated, which would reduce the calculated frequency. The input pressure was measured using a flush-mounted transducer and the output pressure was measured using a transducer mounted in the stepped-recessed cavity. The axial location of the transducers along the tube is identical and equal to 9 in. Note the logarithmic scales on the axes. For further information regarding these series of tests, contact J. D. Rogers, Sandia National Laboratories, Albuquerque, NM.

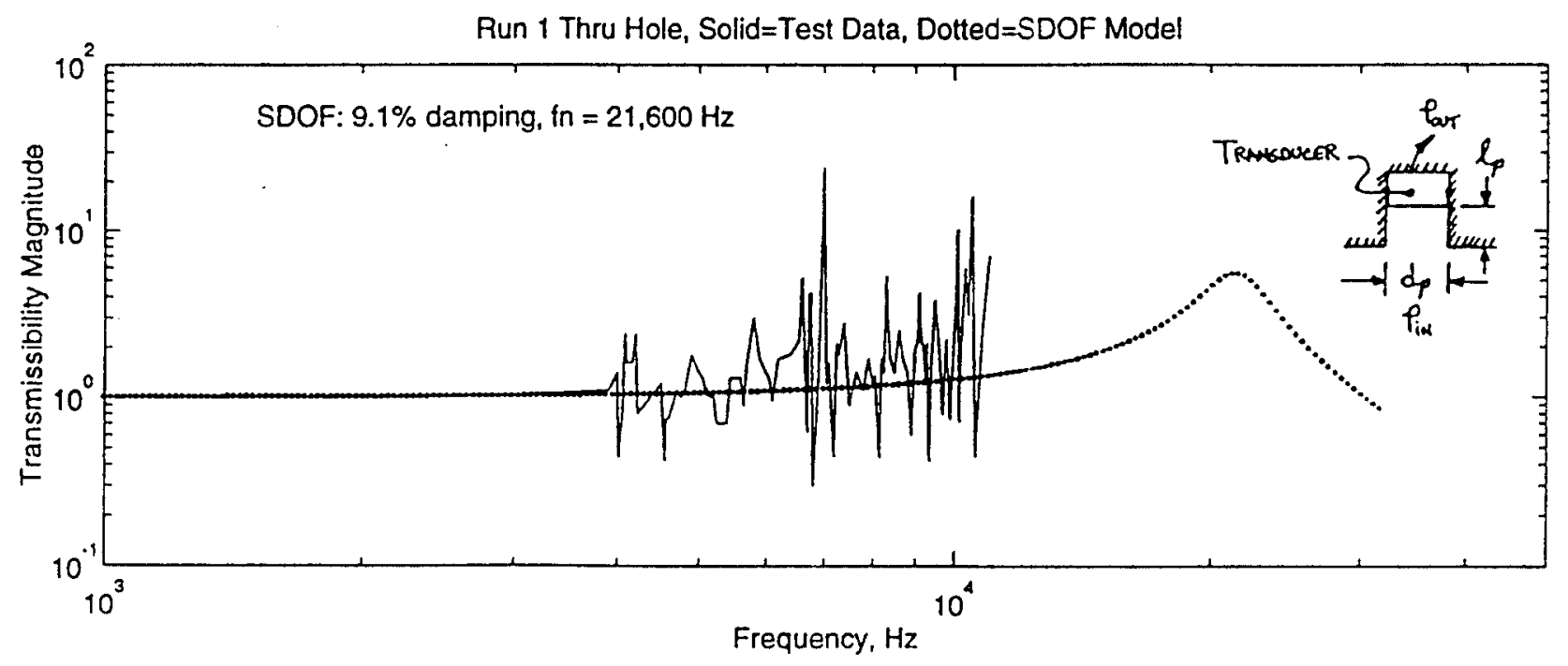

Figure 26. Acoustic pressure-frequency response spectrum for a single-diameter cavity. Solid line, measured data; dashed line, analytical or predicted data using results from Eq. (94) where $\omega_{n}=2 \pi c_{o} / 4 \ell_{p}$. Cavity dimensions (in inches) are $d_{p}=0.242, \ell_{p}=0.157$. The calculated first natural frequency for the cavity is $21,600 \mathrm{~Hz}$. The input pressure was measured using a flush-mounted transducer; the output pressure was measured using a transducer mounted in the single-diameter cavity. The axial location of the transducers along the tube is identical. Note the logarithmic scales on the axes. For further information regarding these series of tests, contact J. D. Rogers, Sandia National Laboratories, Albuquerque, NM. 

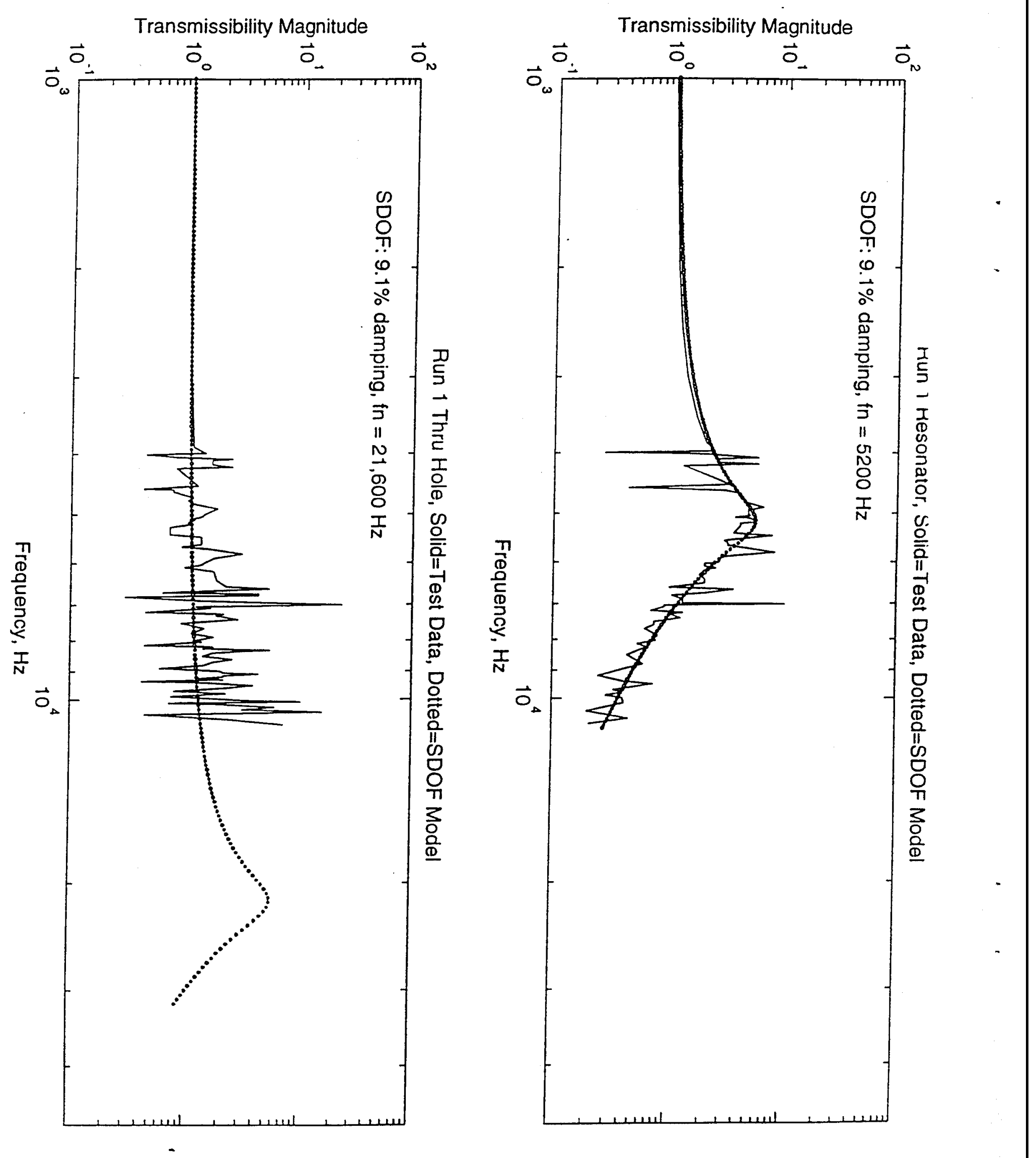


\section{NON-ACOUSTIC MEASUREMENTS}

- CAVITIES FILLED WITH GREASE

- LIQUID COMBUSTOR EXPERIMENT AT SNL/CA 

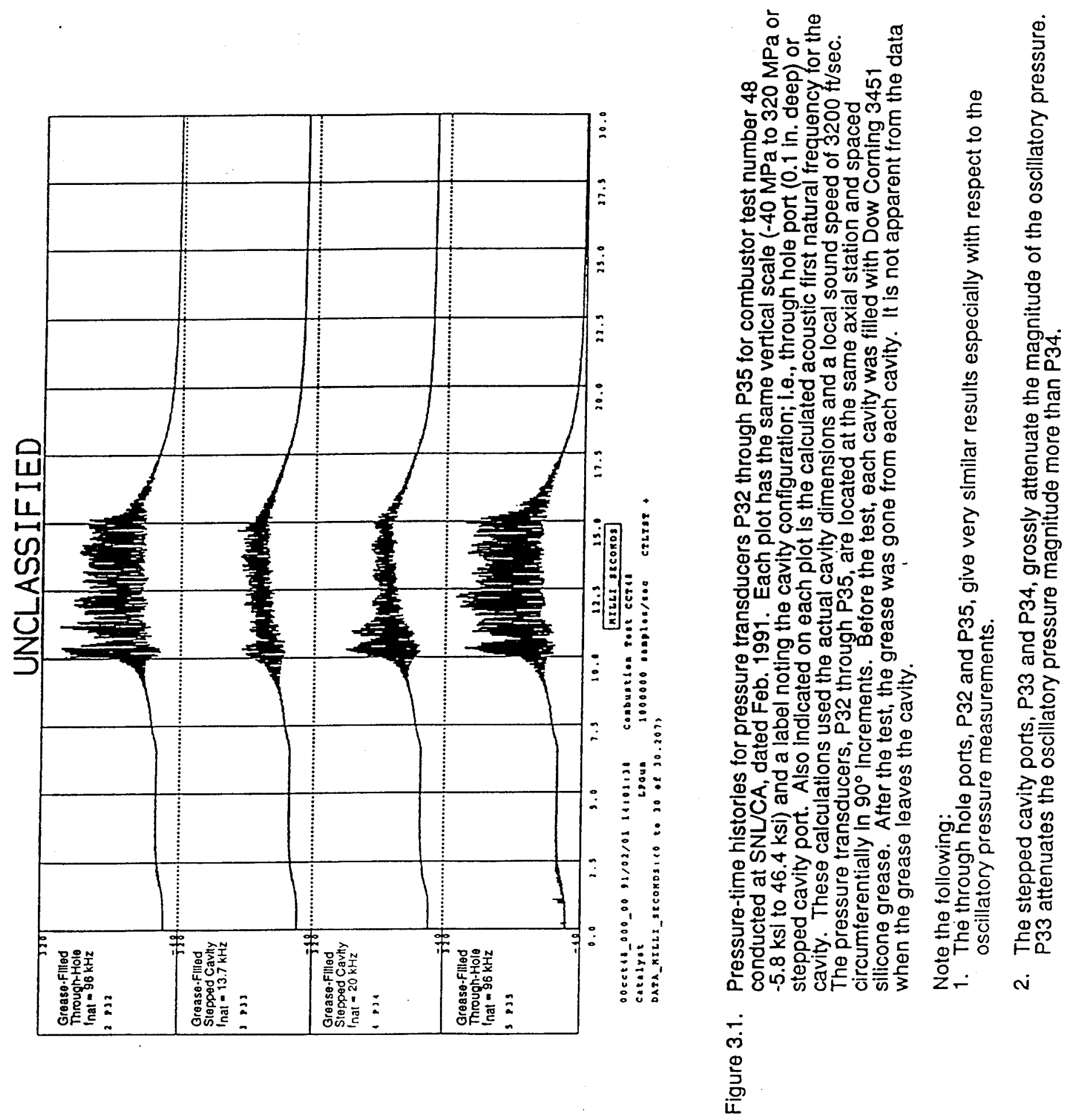

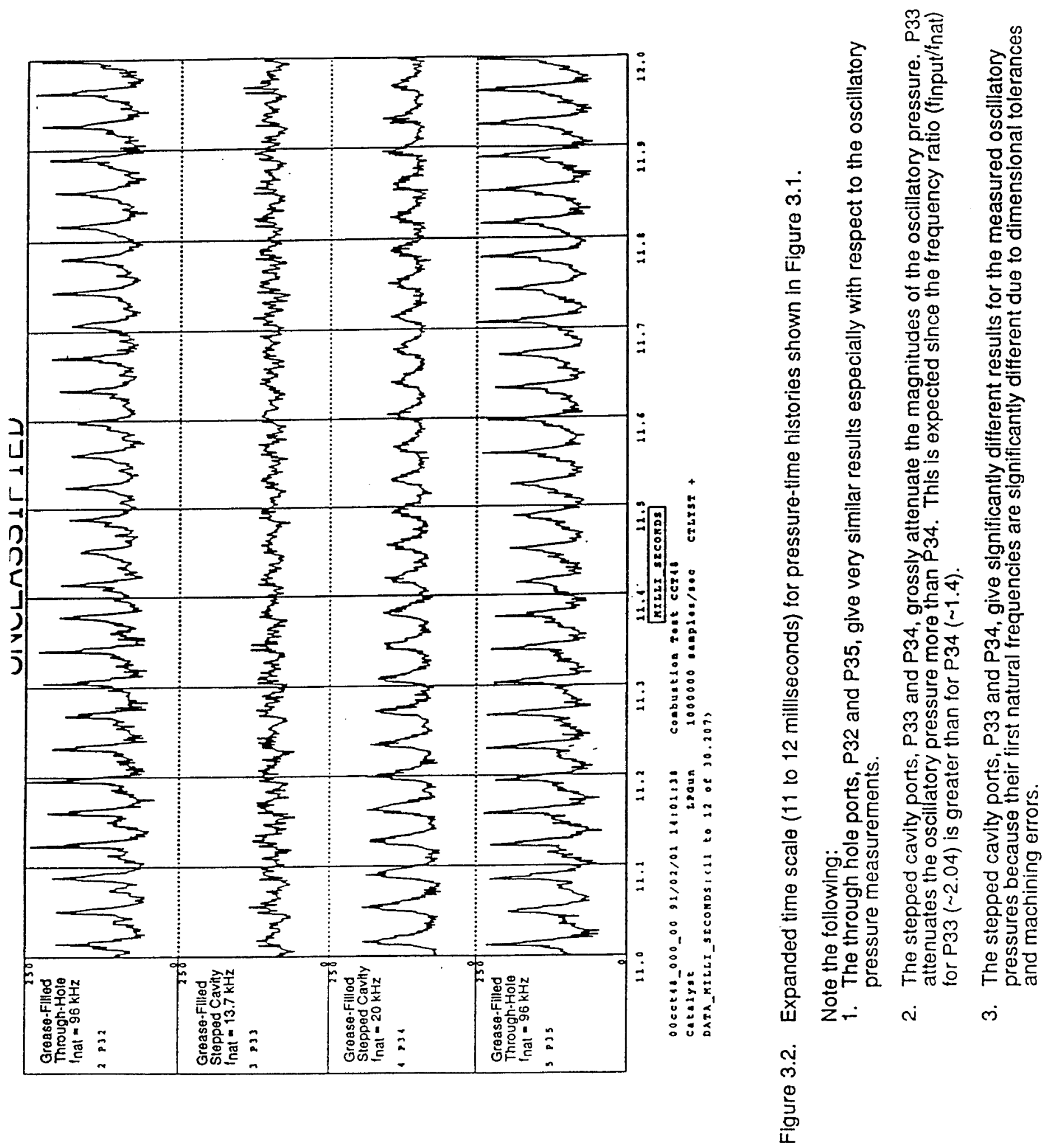


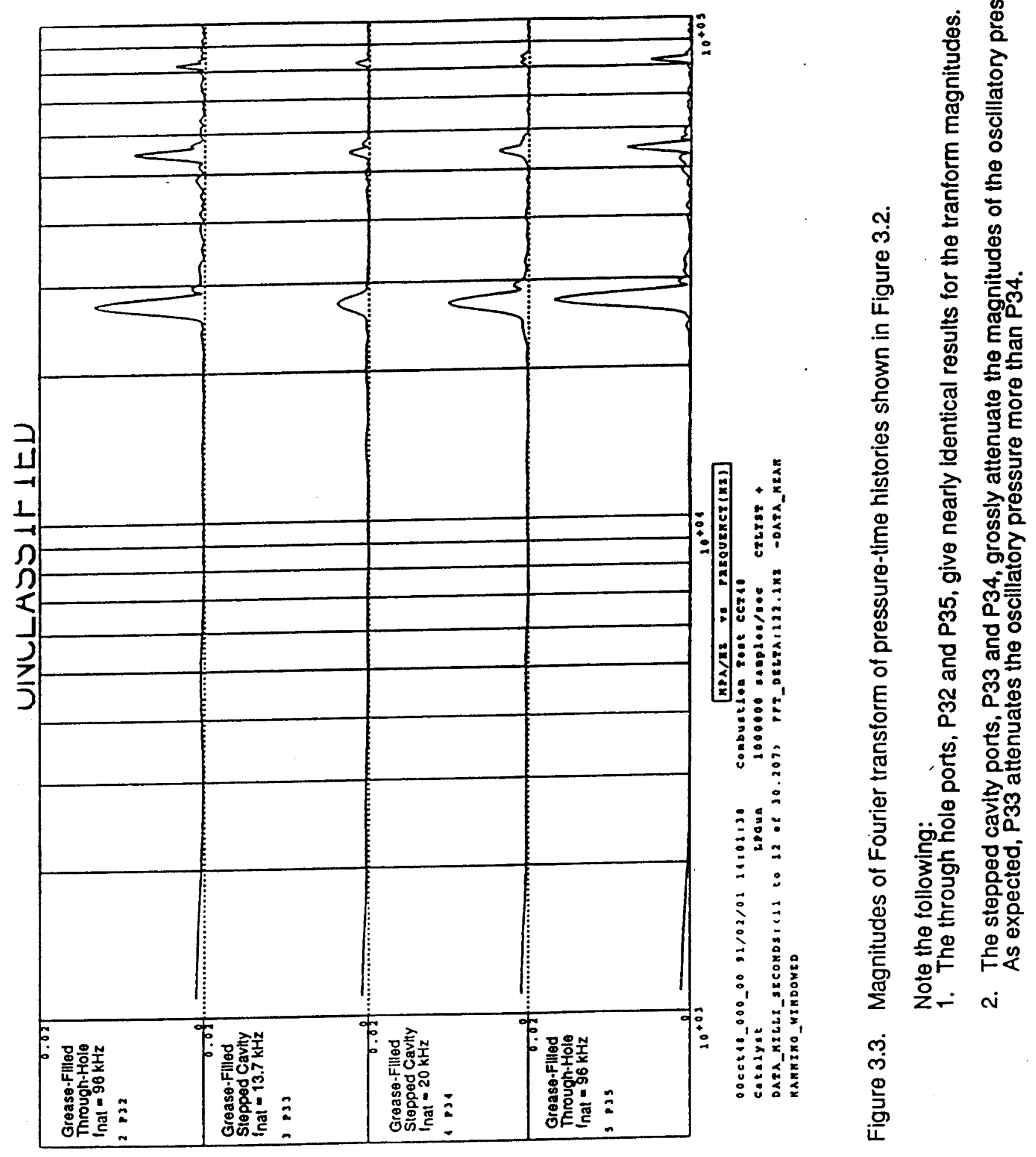



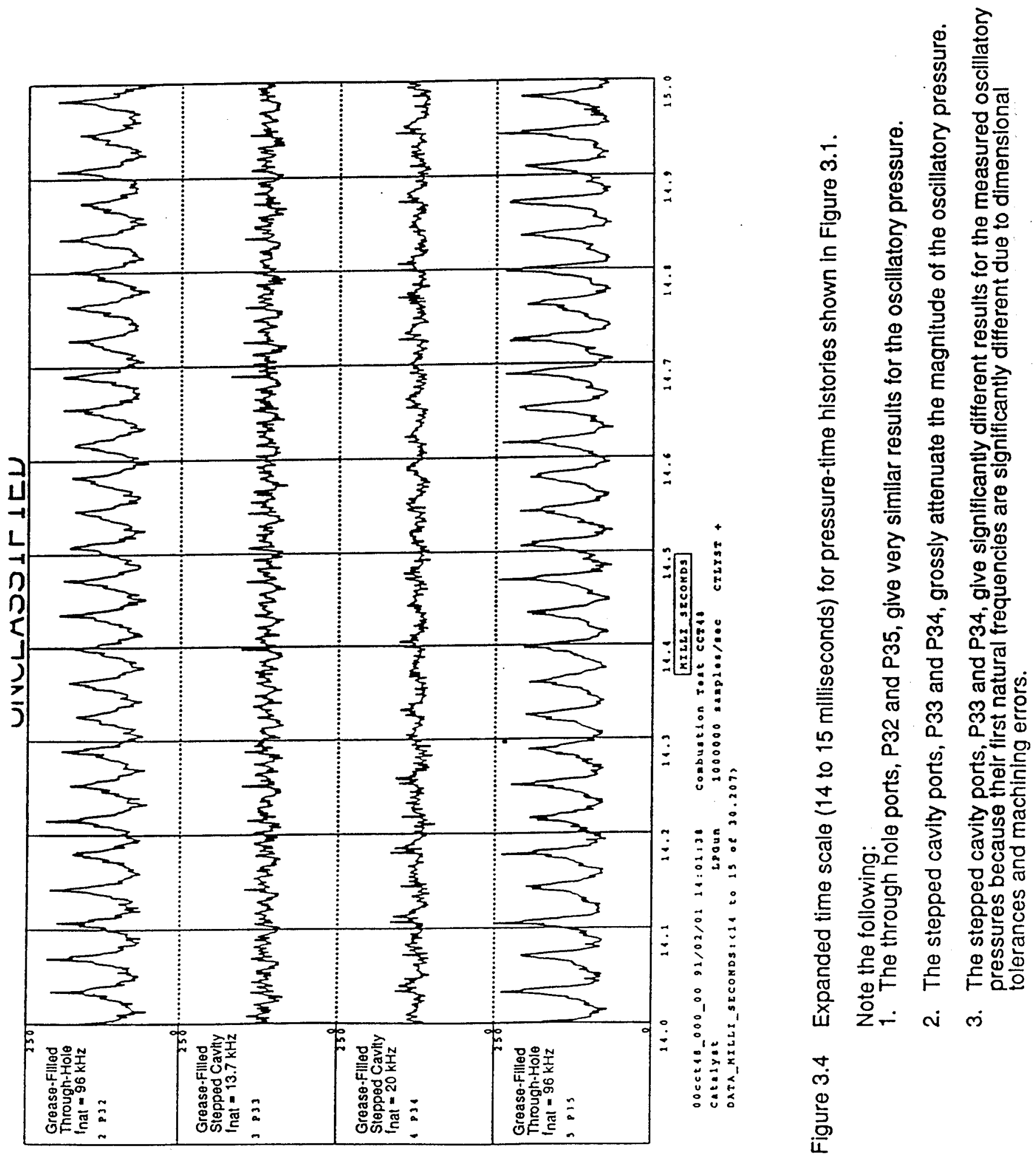

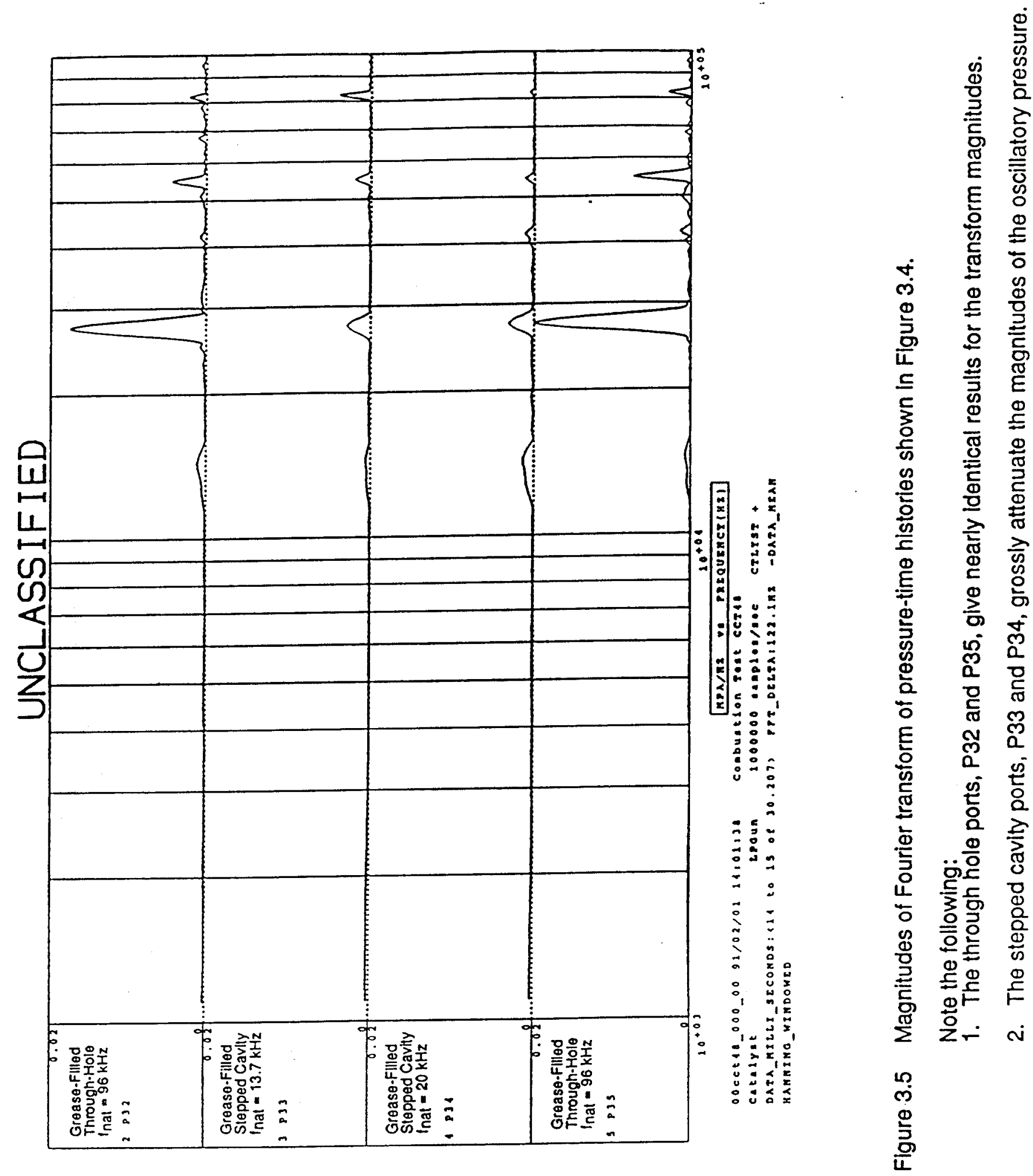
Table 1.

Measurement Error for Max.Oscillatory Pressure

$$
\begin{aligned}
& \text { f } \\
& \text { n } \quad F / F_{\max } \\
& (\mathrm{kHz}) \\
& \left(1-\mathrm{F} / \mathrm{F}_{\max }\right) \mathrm{x} \\
& 2 \quad 0.463 \\
& 0.743 \\
& 0.851 \\
& 0.903 \\
& 0.933 \\
& 0.962 \\
& 0.975 \\
& 0.983 \\
& 80 \\
& 53.3 \\
& 40 \\
& 32 \\
& 26.7 \\
& 20.0 \\
& 16.0 \\
& 13.3 \\
& 53.7 \\
& 25.7 \\
& 14.9 \\
& 9.7 \\
& 6.7 \\
& 3.8 \\
& 2.5 \\
& 1.7 \\
& f=\frac{c_{0}}{\lambda} \\
& \lambda=\text { nd } \\
& c_{0} \cong 40 \times 10^{3} \text { inches } / \mathrm{sec} \\
& \cdot d \equiv 0.25 \text { inches } \\
& \text { \% error }=\left\{1-\frac{2 n}{\pi}\left[\frac{n}{\pi}\left(-1+\cos \frac{\pi}{n}\right)+\sin \frac{\pi}{n}\right]\right\} \times 100 \\
& f=\frac{c_{0}}{n d}
\end{aligned}
$$
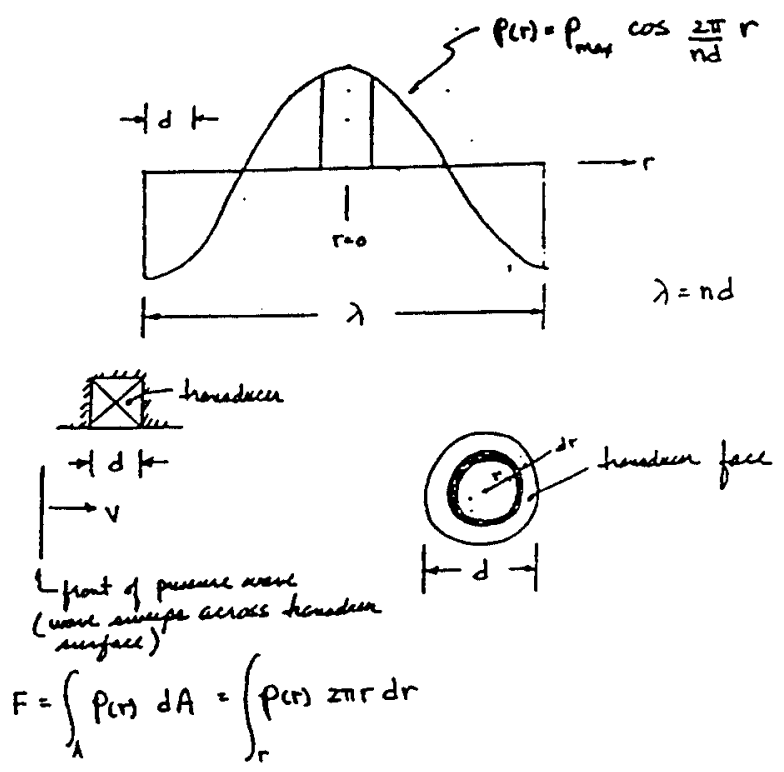


\section{CONCLUSIONS}

- Accurately measured oscillatory pressure-time histories are required to determine the dynamic structural response for projectiles (as well as for guns) and to assess their structural integrity with respect to oscillatory pressure environments in regenerative liquid propellant guns.

- Filling through-hole and stepped cavity pressure gage (transducer) mounting ports with grease does not mitigate gross differences between measured oscillatory pressures.

- Stepped-recessed pressure transducer cavities, which may be grease-filled, are suitable for measuring quasistatic pressure in solid propellant guns and regenerative liquid propellant guns, provided the frequencies contained in the quasi-static pressure pulse are low relative to the fundamental frequency for the empty stepped cavity. 


\section{CONCLUSIONS}

- Most of the oscillatory pressure measurements in liquid propellant guns have been made using a stepped cavity where the fundamental frequency of the cavity is low (rather than high) compared to the highest measured input frequency of interest. Consequently, the accuracy of the measured oscillatory pressure data base is severely limited relative to the frequency range of interest (e.g., up to $50 \mathrm{kHz}$ ).

- It is strongly recommended that this issue be resolved so that the structural integrity of projectiles in the inventory can be accurately assessed when subjected to the oscillatory pressure environment associated with RLPGs.

- Accurate high frequency oscillatory pressure measurements depend not only on the transducer's cavity configuration, frequency response of the measurement system, etc., but also on the diameter of the transducer's sensing element. 
INTENTIONALLY LEFT BLANK. 


\section{APPENDIX D: \\ PRESENTATION - "FURTHER EVIDENCE OF THE EFFECTS OF TWO DIAMETER TRANSDUCER CAVITIES ON PRESSURE MEASUREMENTS"}

This Appendix is presented in its original form without editorial changes or comments. 
INTENTIONALLY LEFT BLANK. 

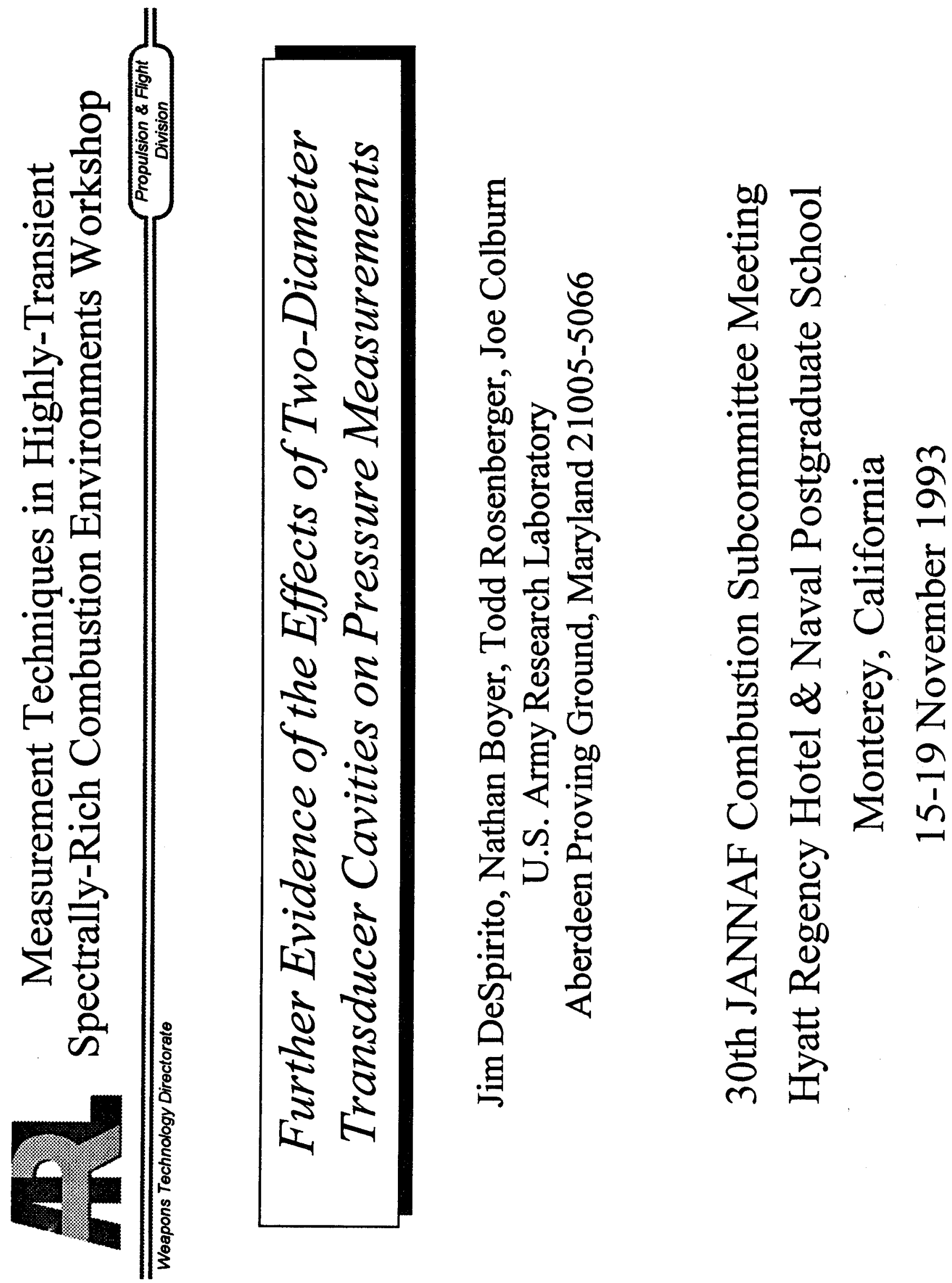


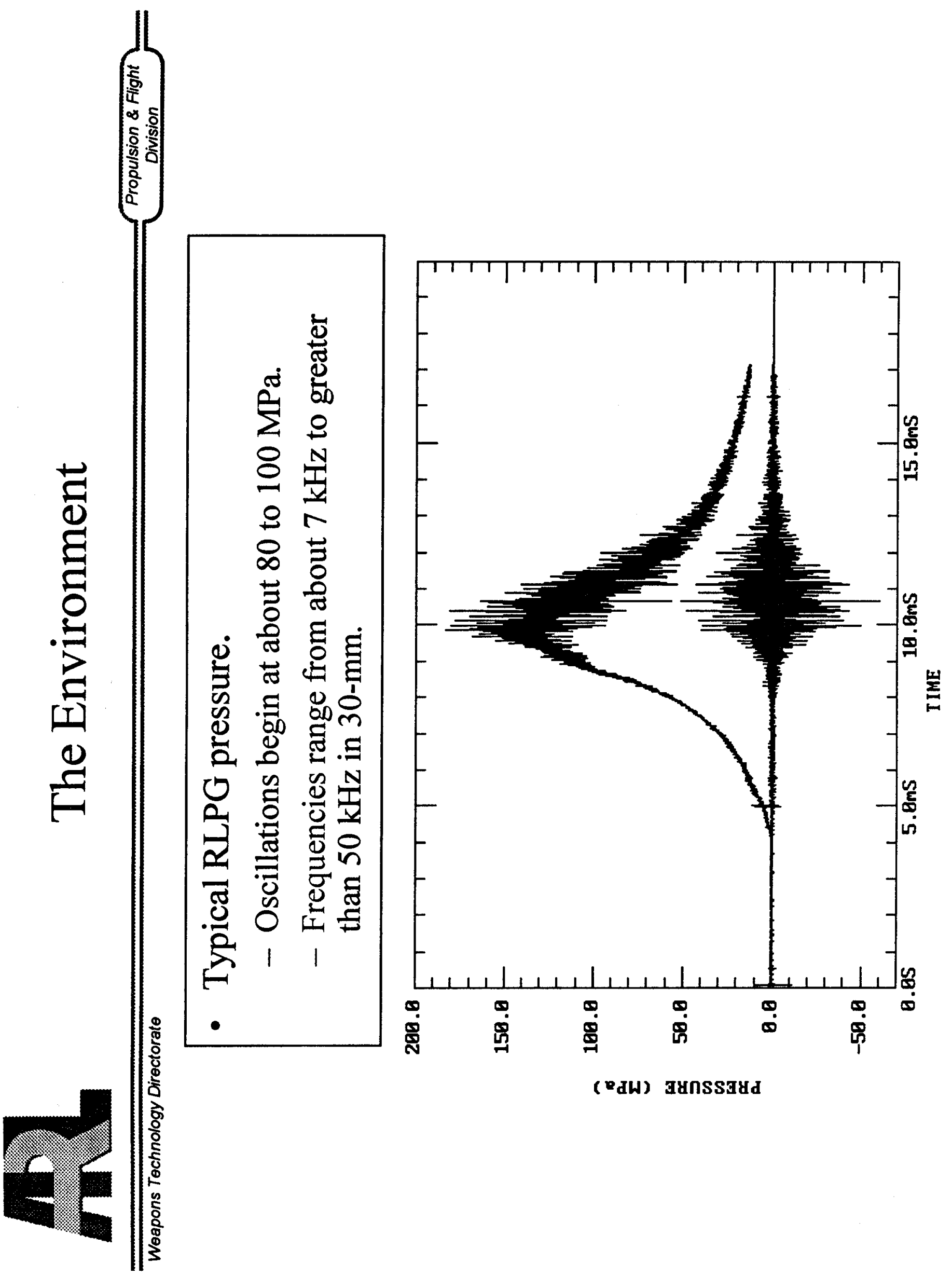




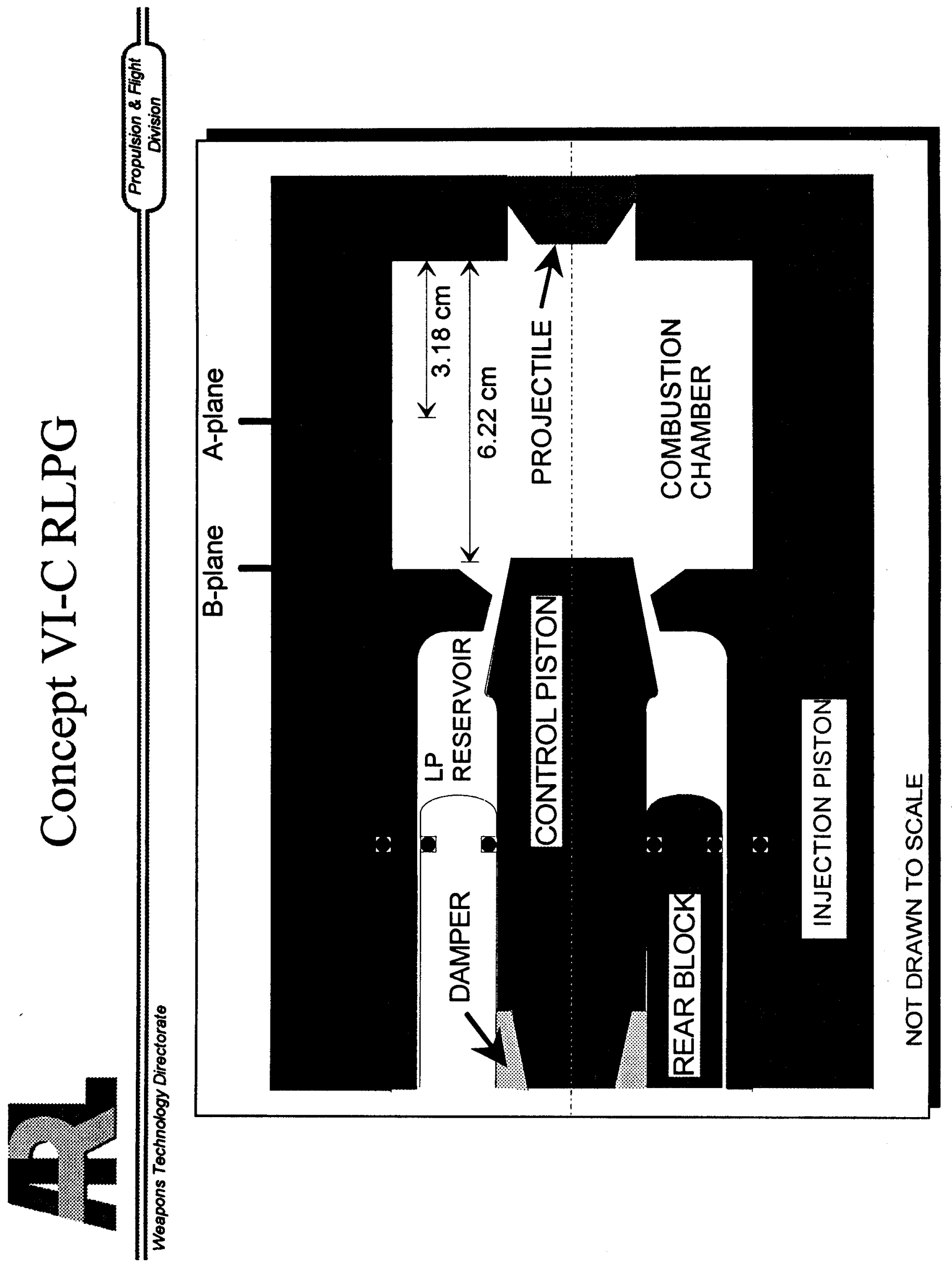




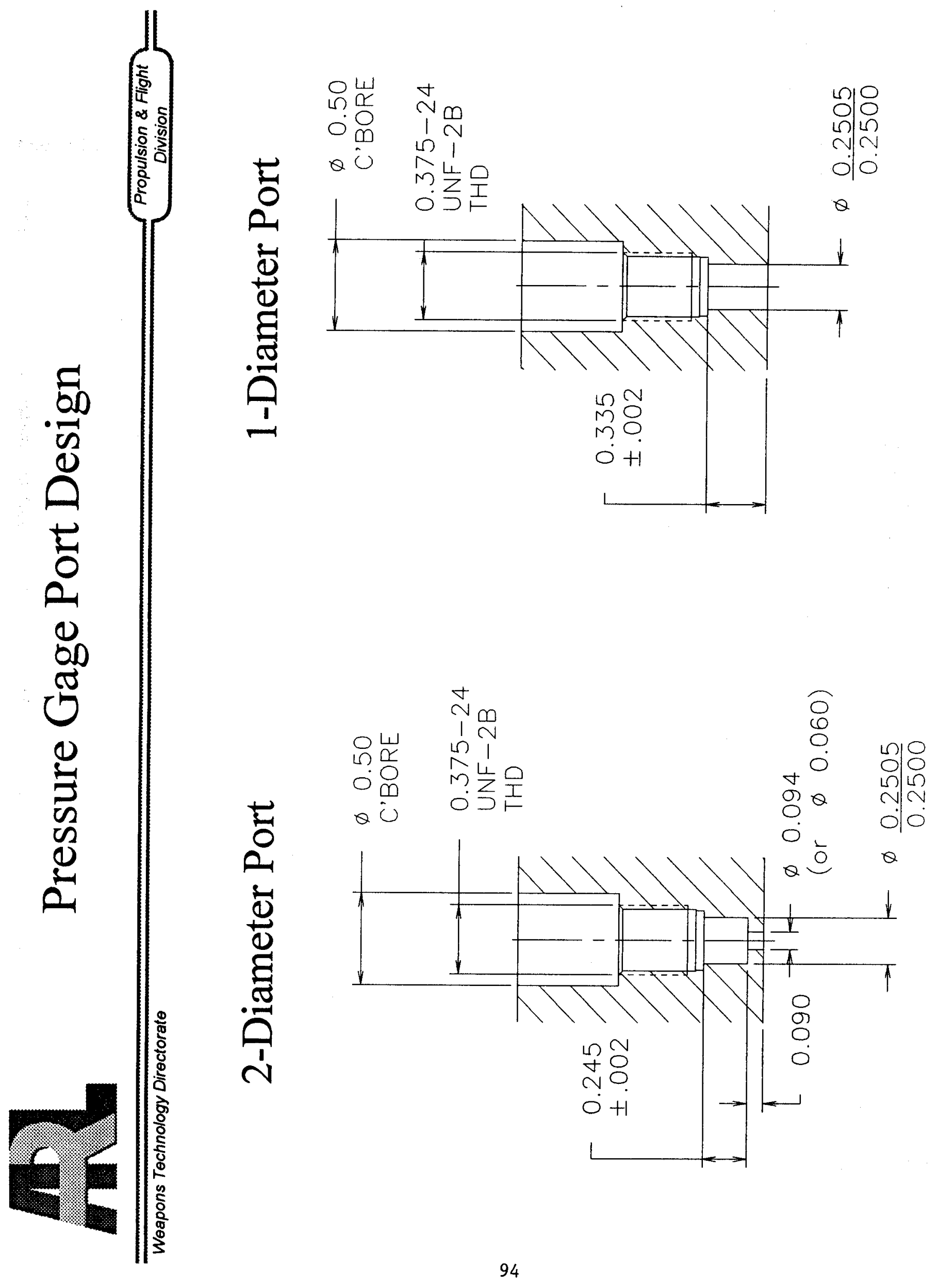




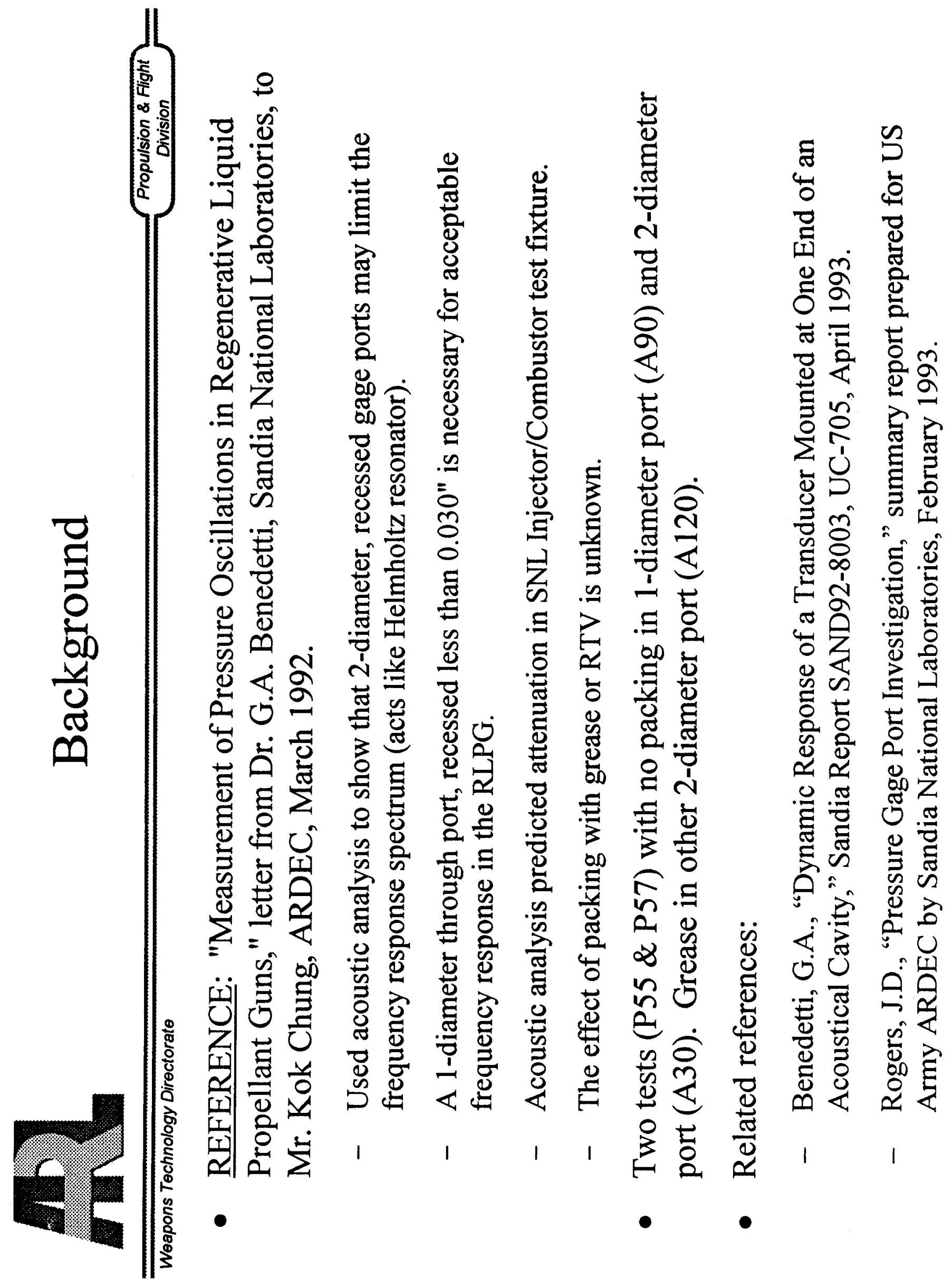




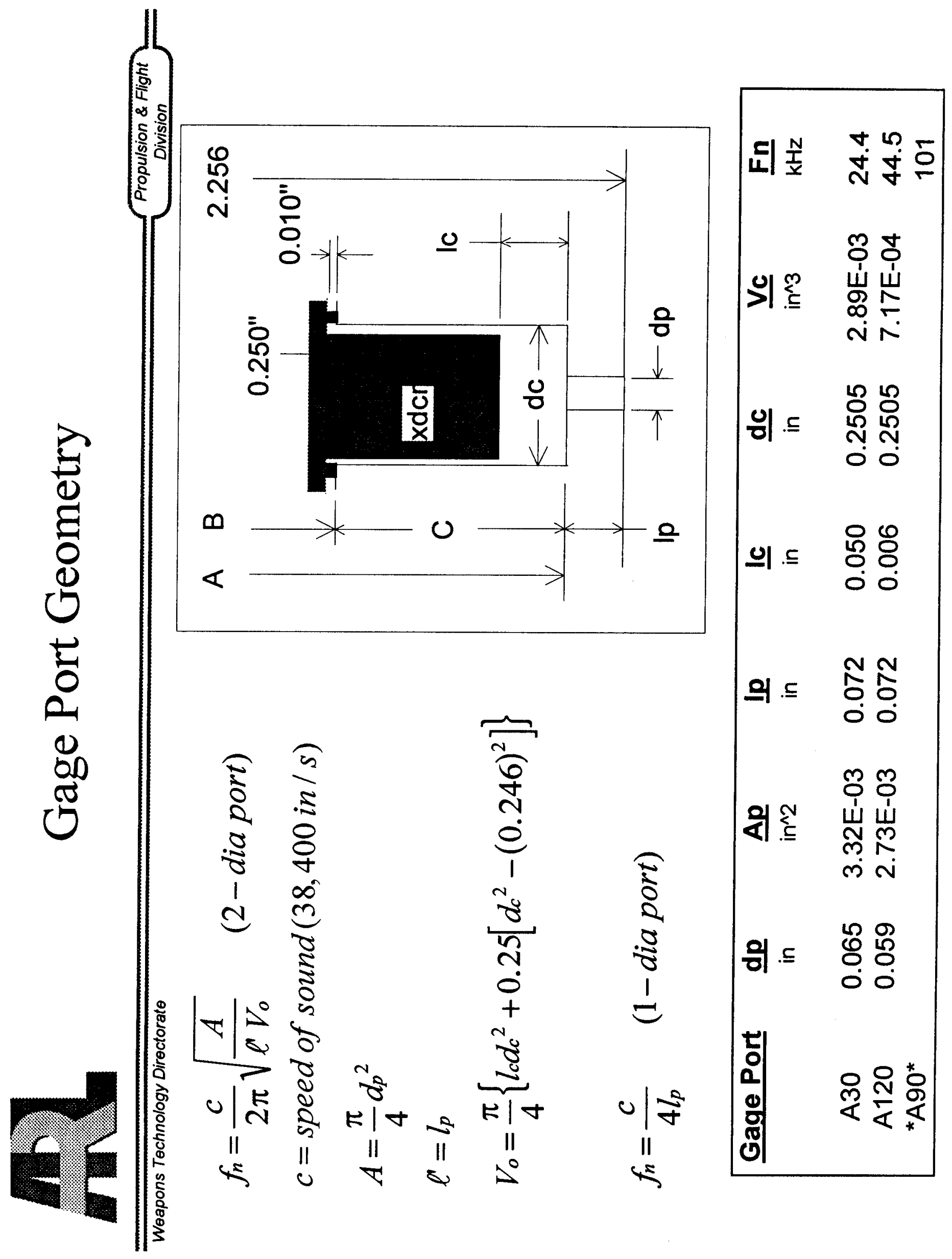




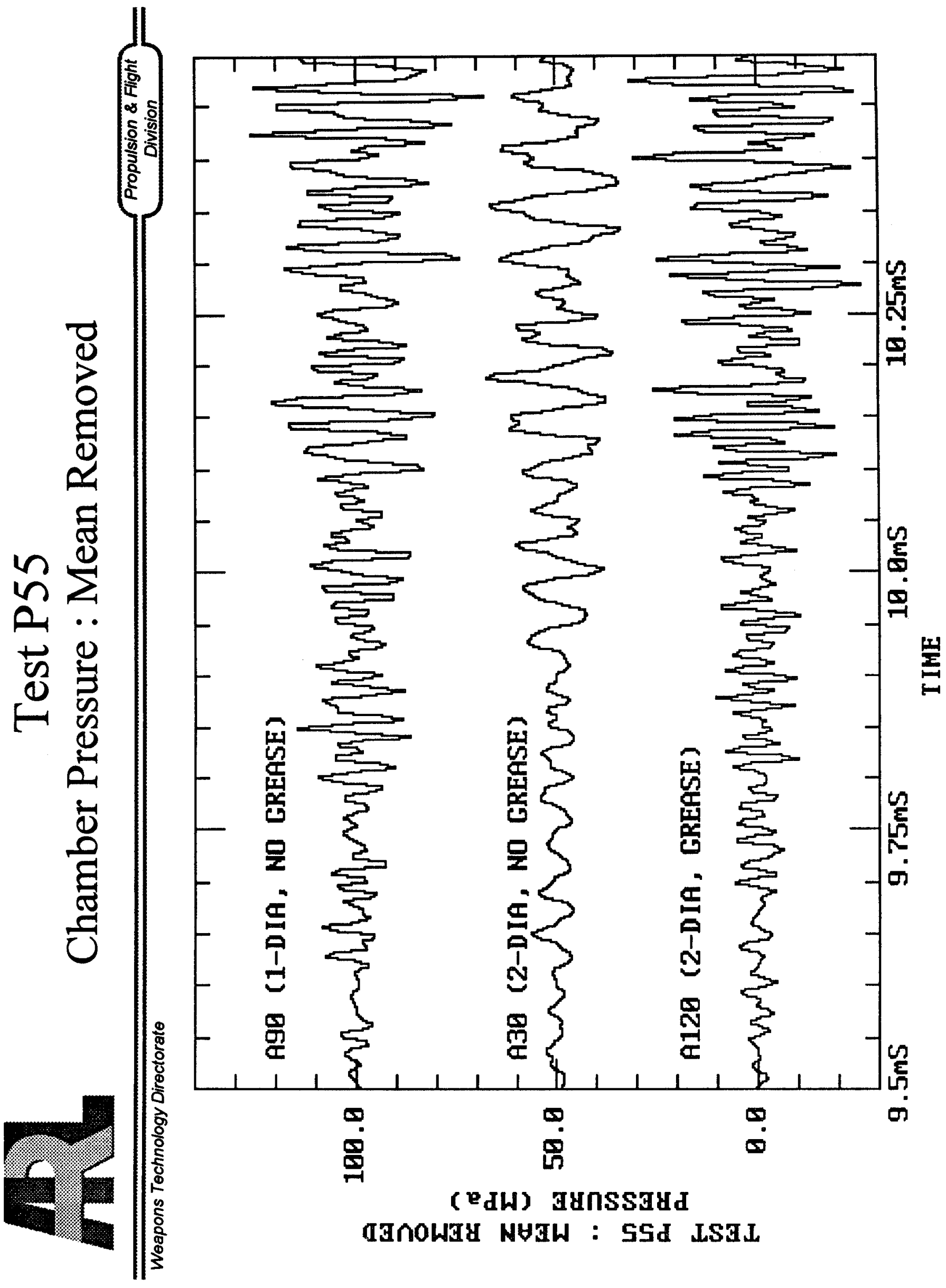




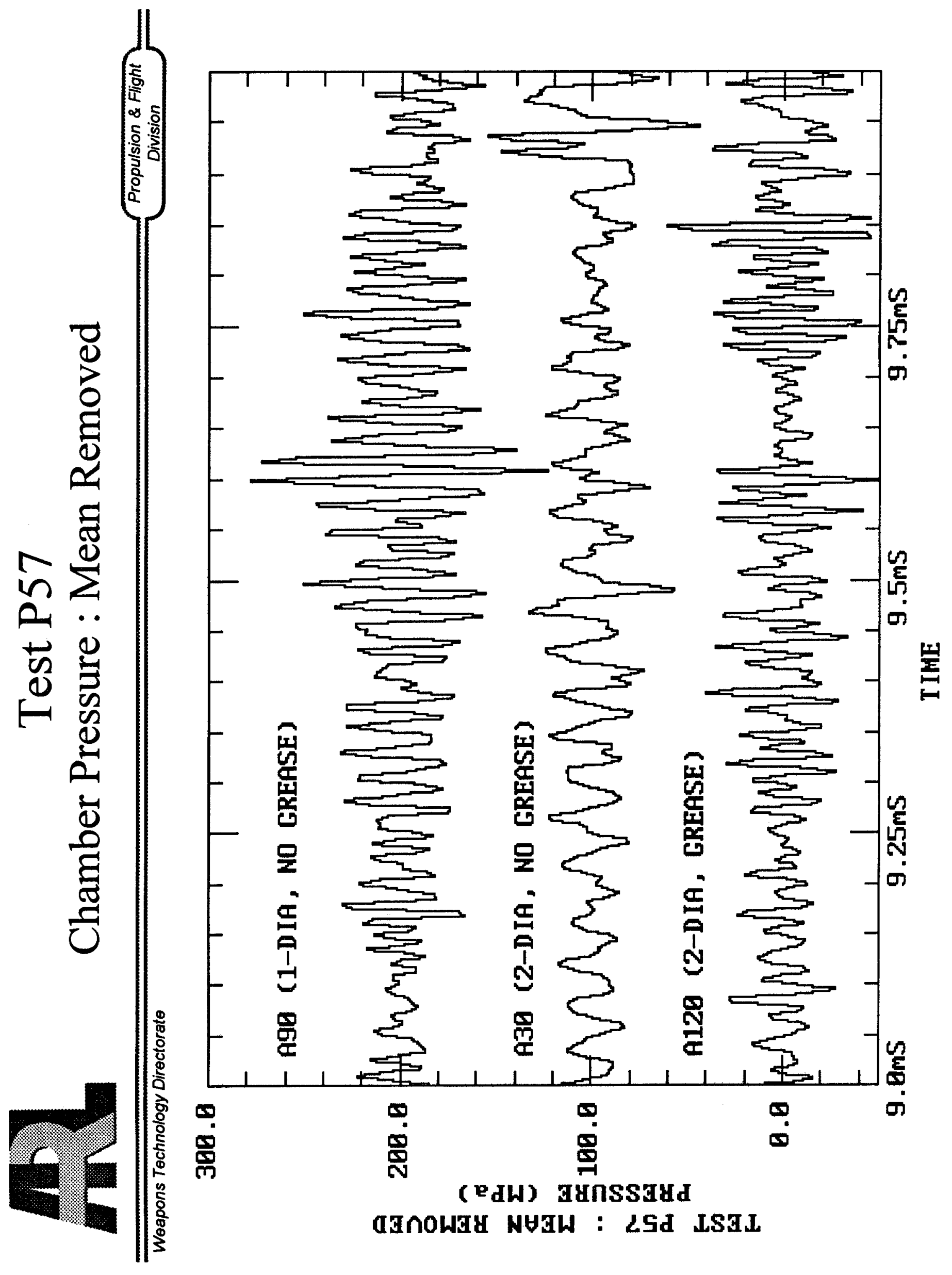



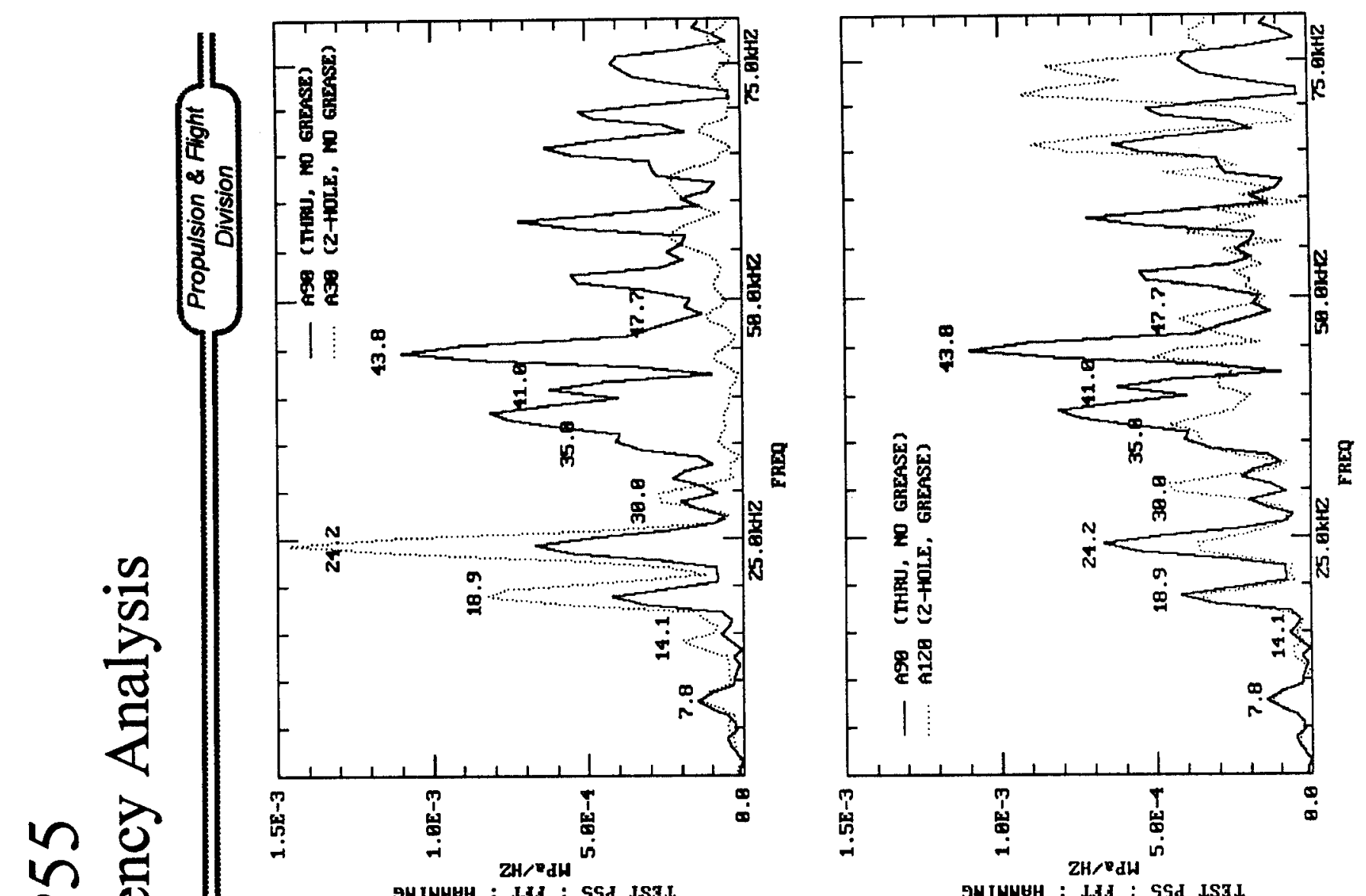

ON INAGH : LAS : SSd LSTL

SNINMGH : LIJ : SSA ISII

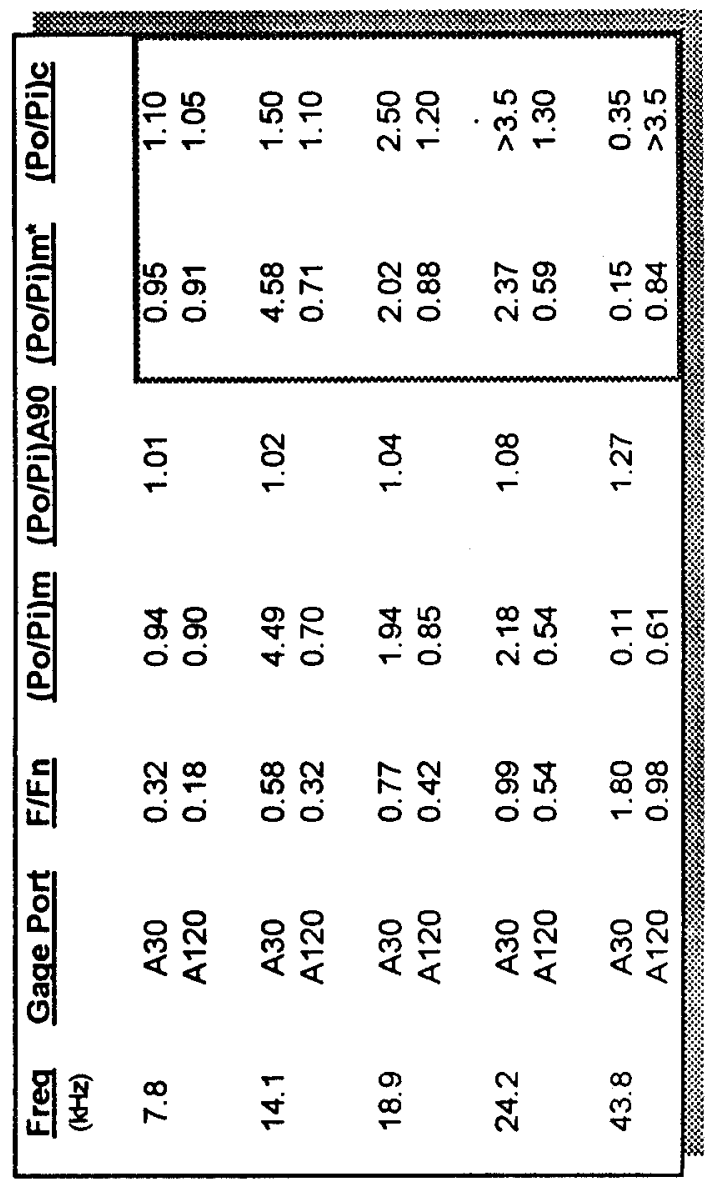



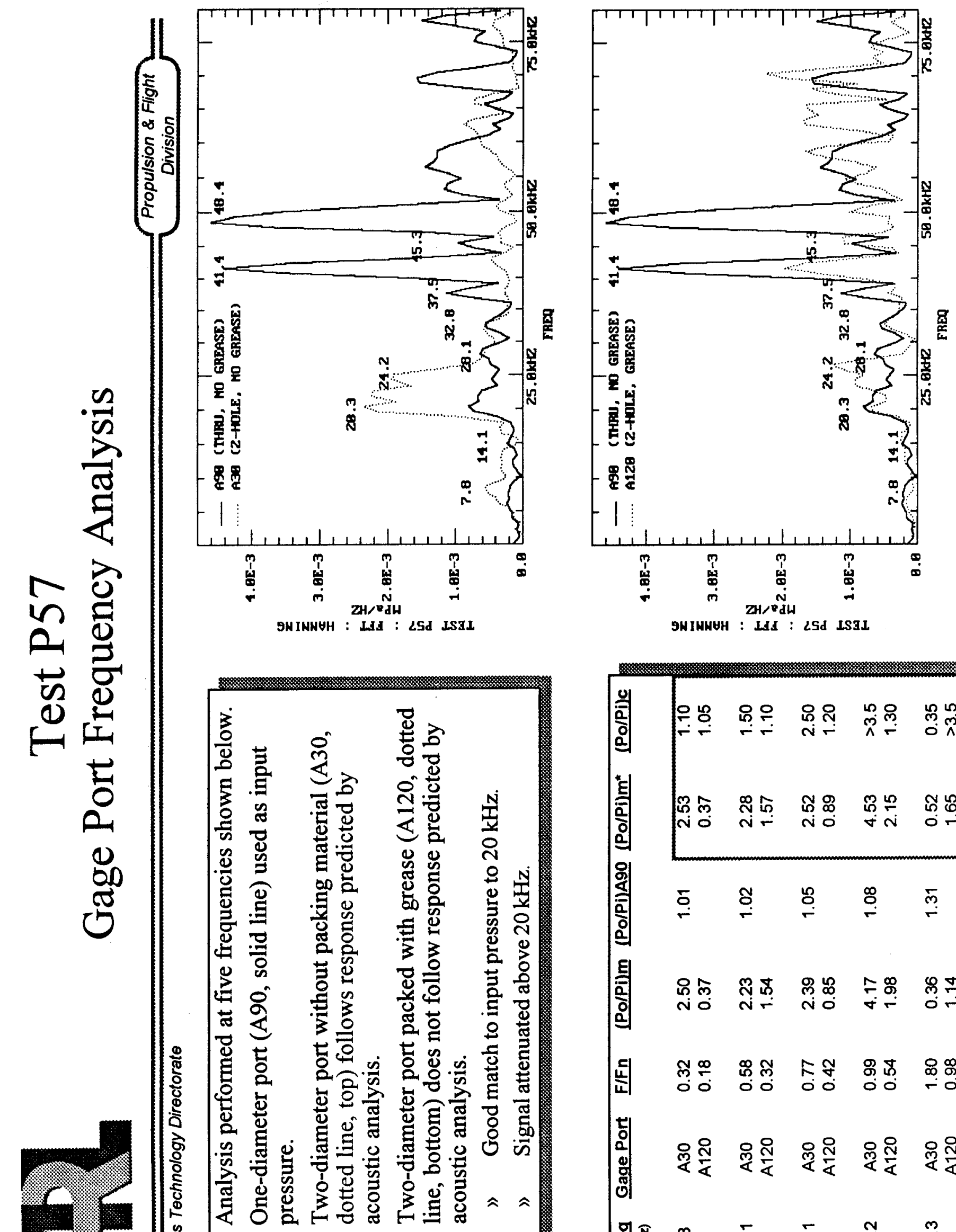

\begin{tabular}{|c|c|c|c|c|c|}
\hline 읨 & $\stackrel{ }{ } \stackrel{ }{-}$ & 웅음 & 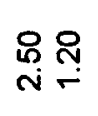 & $\ddot{n}_{n}^{n} \stackrel{p}{-}$ & $\prod_{0}^{\mathscr{m}}$ \\
\hline 틔 응 & مُ & 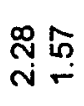 & 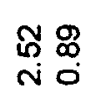 & 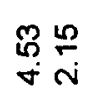 & 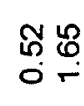 \\
\hline 응 & $\stackrel{\sigma}{\sigma}$ & $\stackrel{\circ}{\circ}$ & $\stackrel{8}{8}$ & $\stackrel{\circ}{\circ}$ & $\stackrel{\text { m }}{\leftarrow}$ \\
\hline 긍 & 员 & 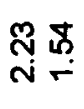 & 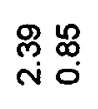 & $\begin{array}{l}\text { F⿻ } \\
+ \\
+\end{array}$ & $\begin{array}{l}\mathscr{S} \\
0 \\
0\end{array}$ \\
\hline |둔 & $\stackrel{\text { న్ }}{0} \underset{0}{\infty}$ & $\begin{array}{l}\text { : } \\
0 \% \\
0 \%\end{array}$ & $\begin{array}{l}\hat{N} \\
0 \\
0\end{array}$ & 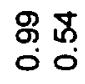 & \begin{tabular}{l}
8 \\
$\infty$ \\
\hdashline \\
\hdashline \\
0
\end{tabular} \\
\hline$\left|\begin{array}{l}t \\
0 \\
0 \\
0 \\
0 \\
0 \\
0\end{array}\right|$ & 足诲 & 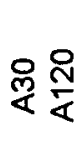 & 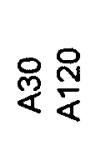 & 足 & 品脢 \\
\hline 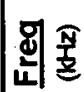 & $\stackrel{\infty}{\sim}$ & $\underset{\leftarrow}{\leftarrow}$ & $\dot{i}$ & $\stackrel{\stackrel{\sim}{*}}{\underset{N}{*}}$ & $\stackrel{m}{\mathfrak{g}}$ \\
\hline
\end{tabular}




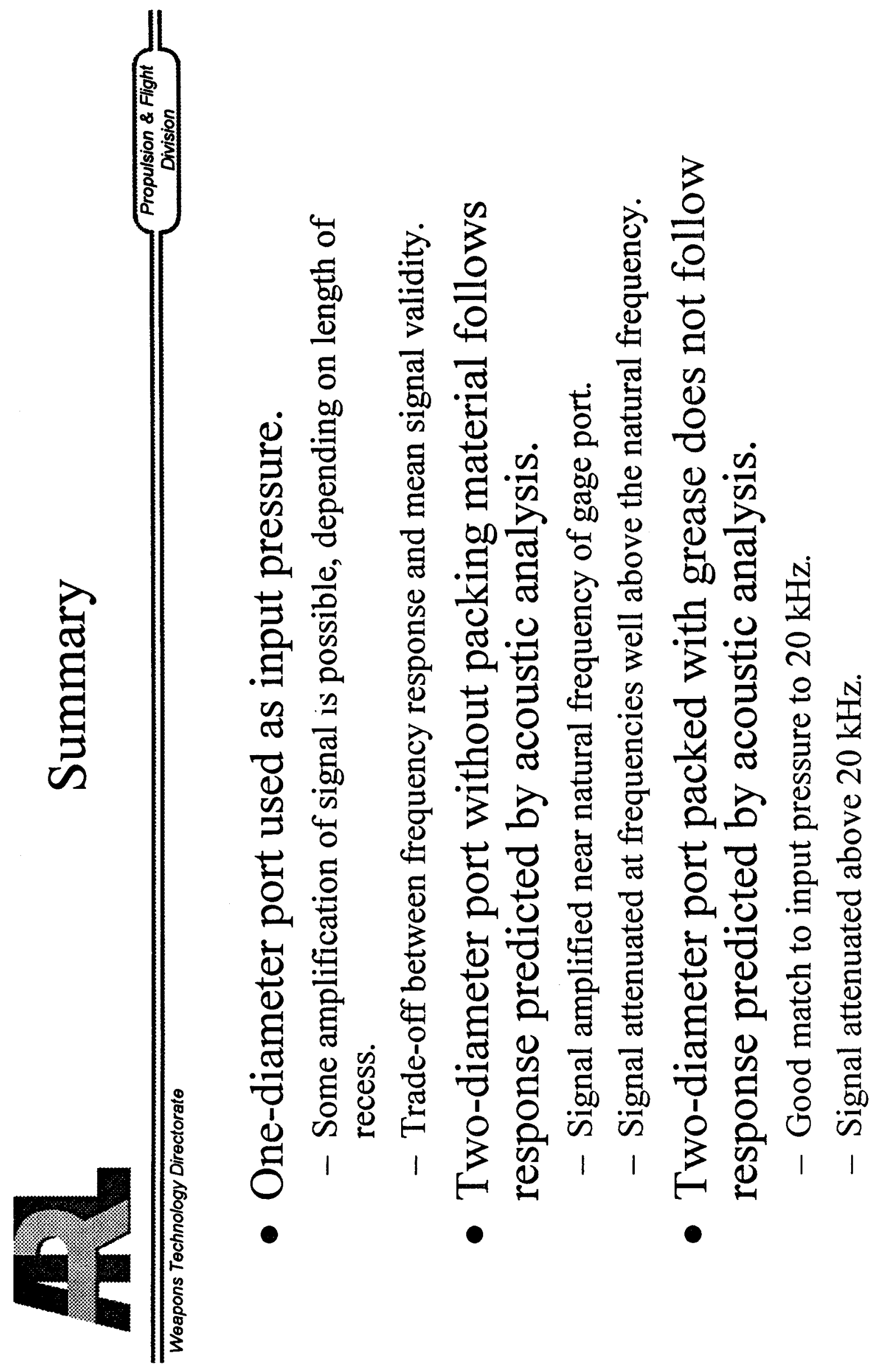




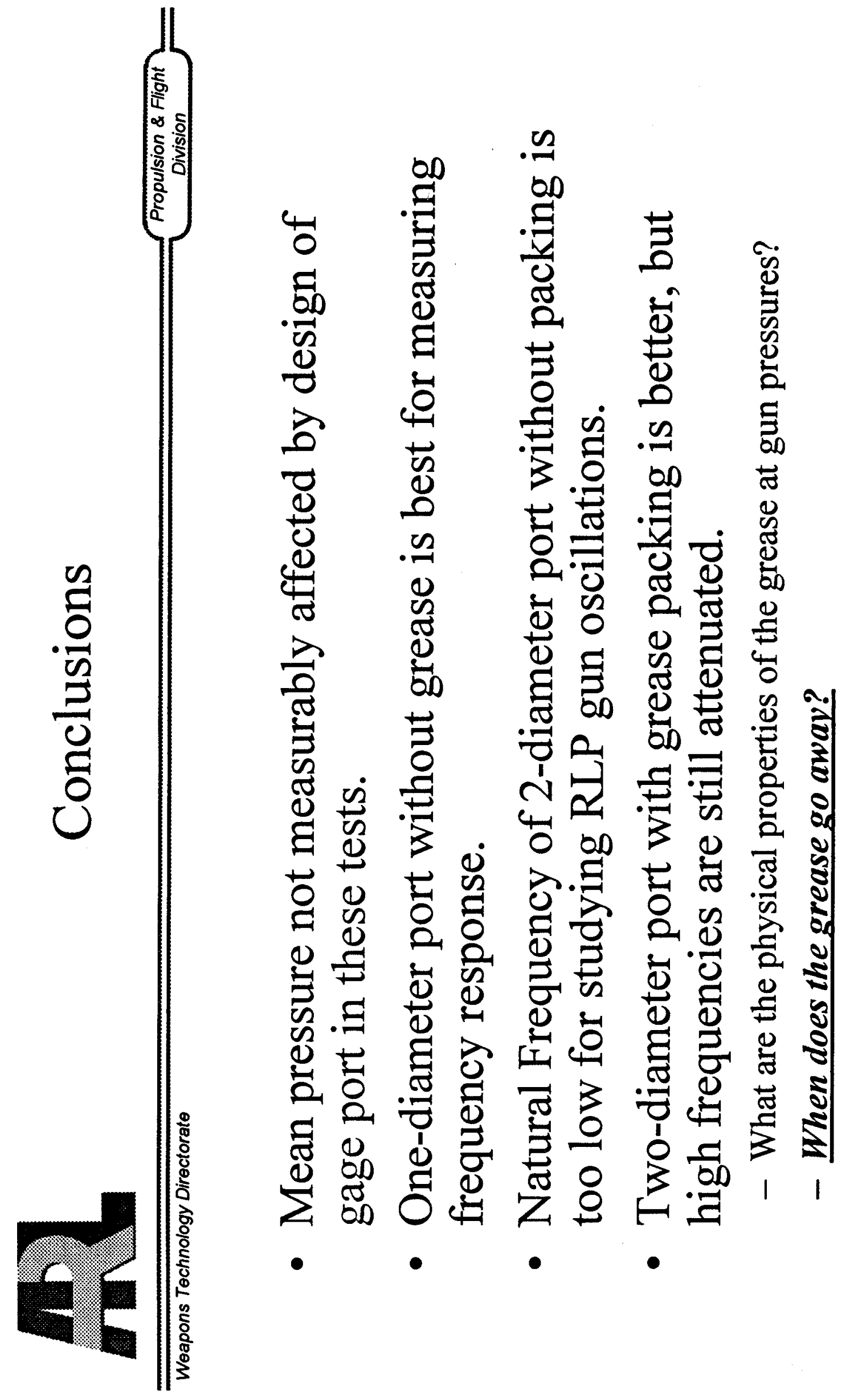




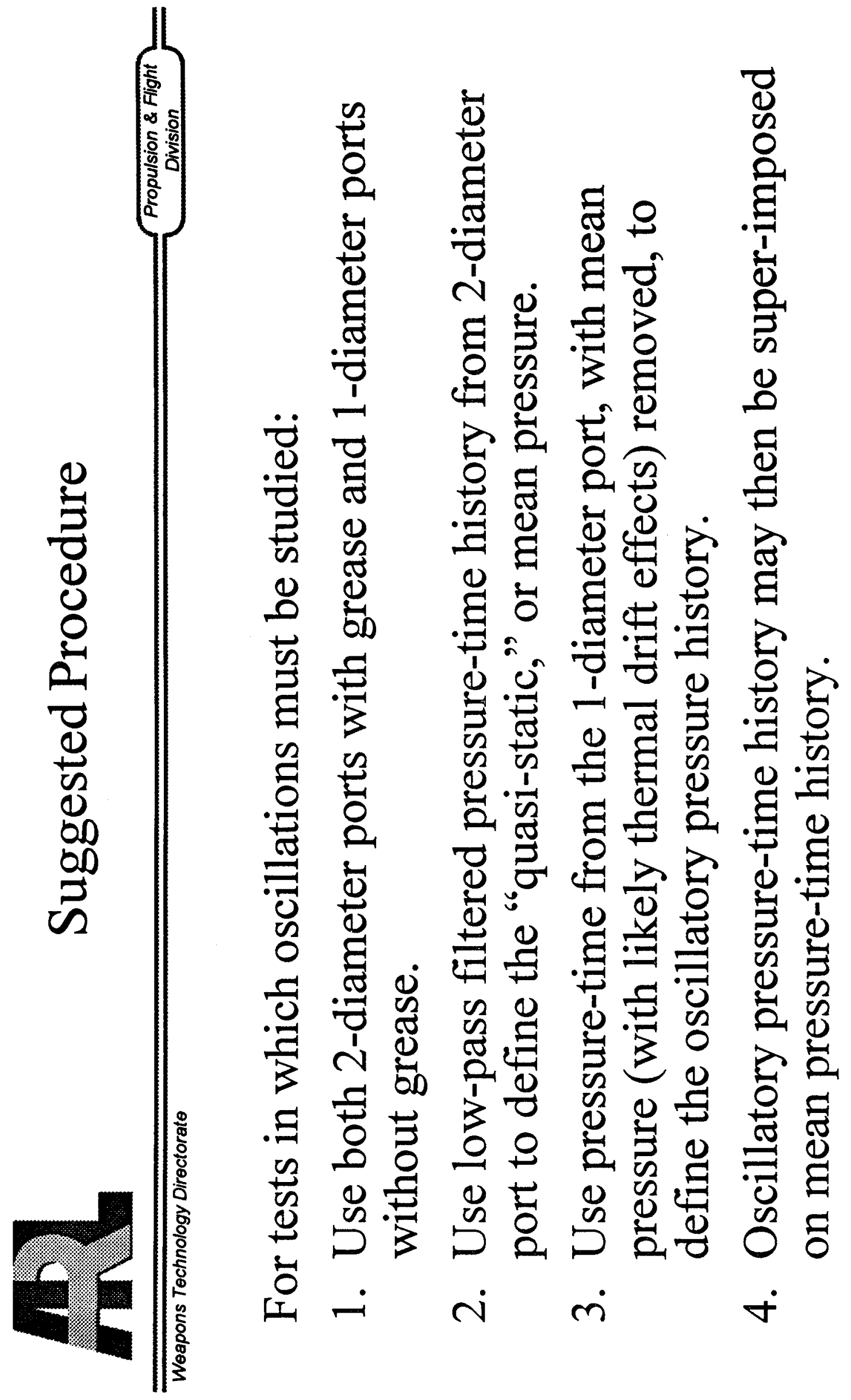


INTENTIONALLY LEFT BLANK. 
APPENDIX E:

PRESENTATION - "HIGH FREQUENCY PRESSURE OSCILLATIONS IN THE IN BORE RAMJET ACCELERATOR"

This Appendix is presented in its original form without editorial changes or comments. 
INTENTIONALLY LEFT BLANK. 

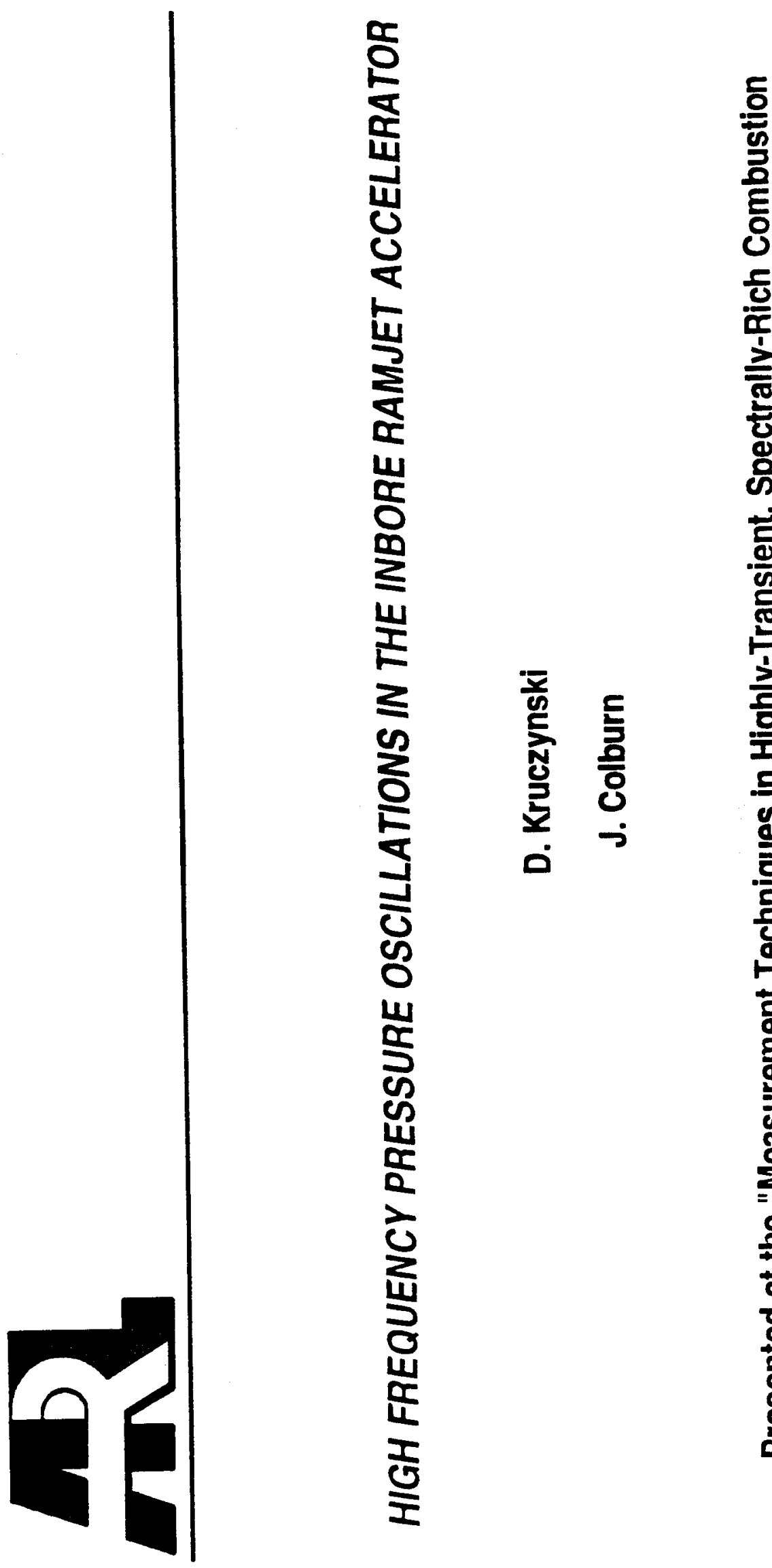

זี

क

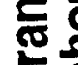

$\frac{2}{0}$
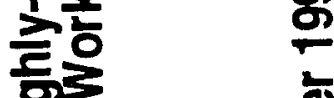

요

II

드릉

르응 z

드난 은

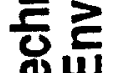

IU

F

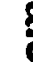

는

(⿻日禸

$\sum$

E

(1)

邑 


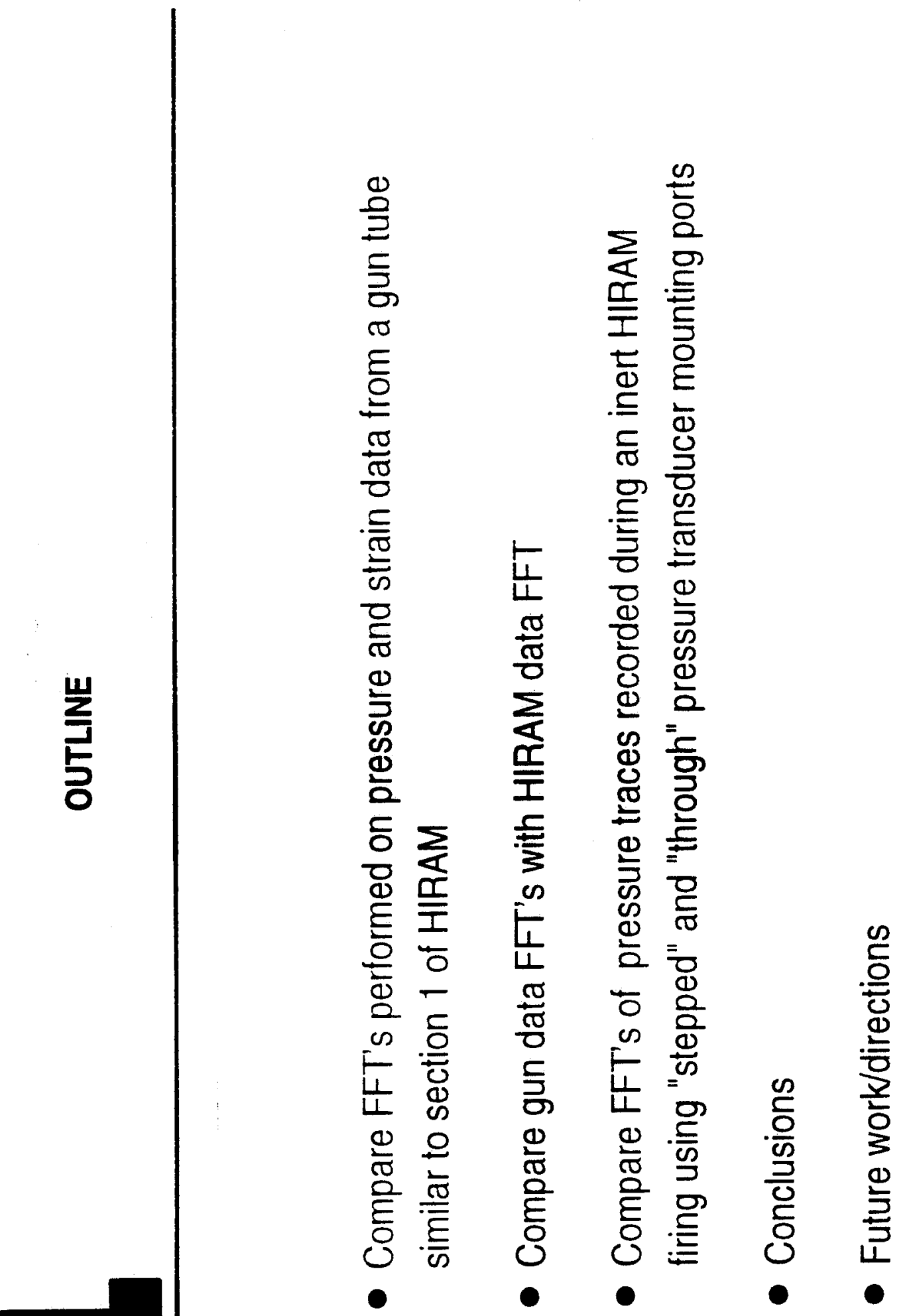



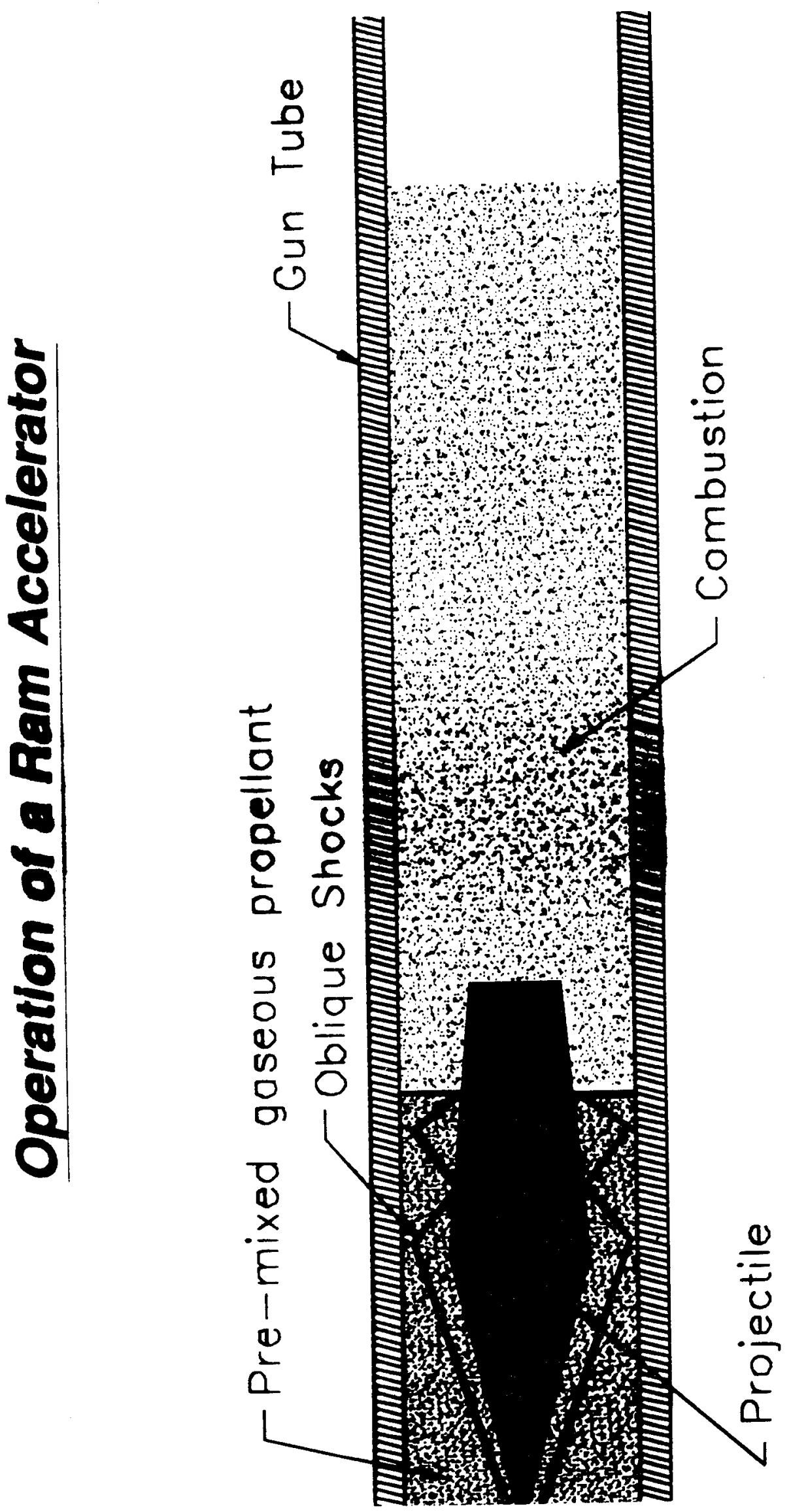


\section{Computed and Experimental Pressure Distributions}

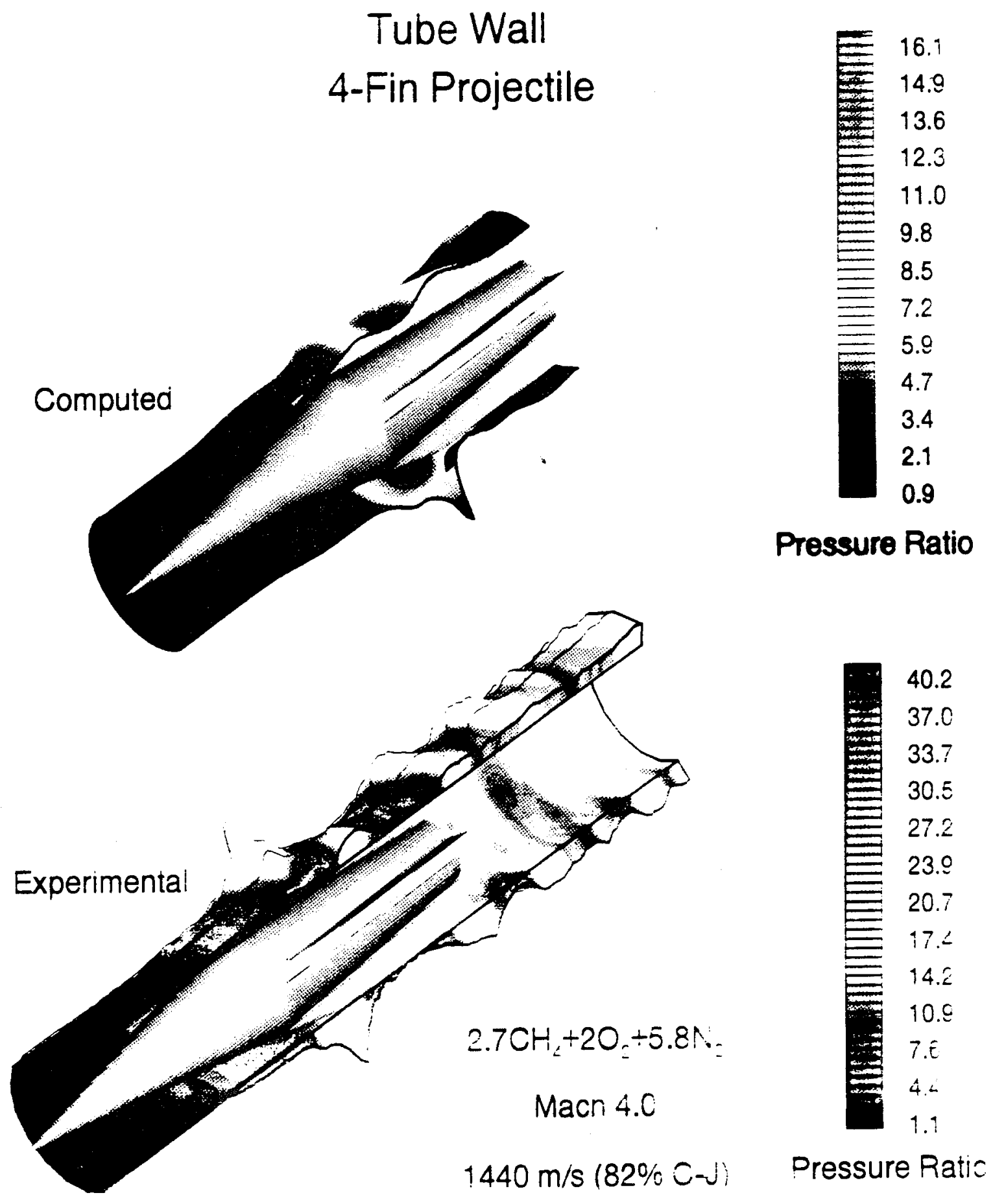




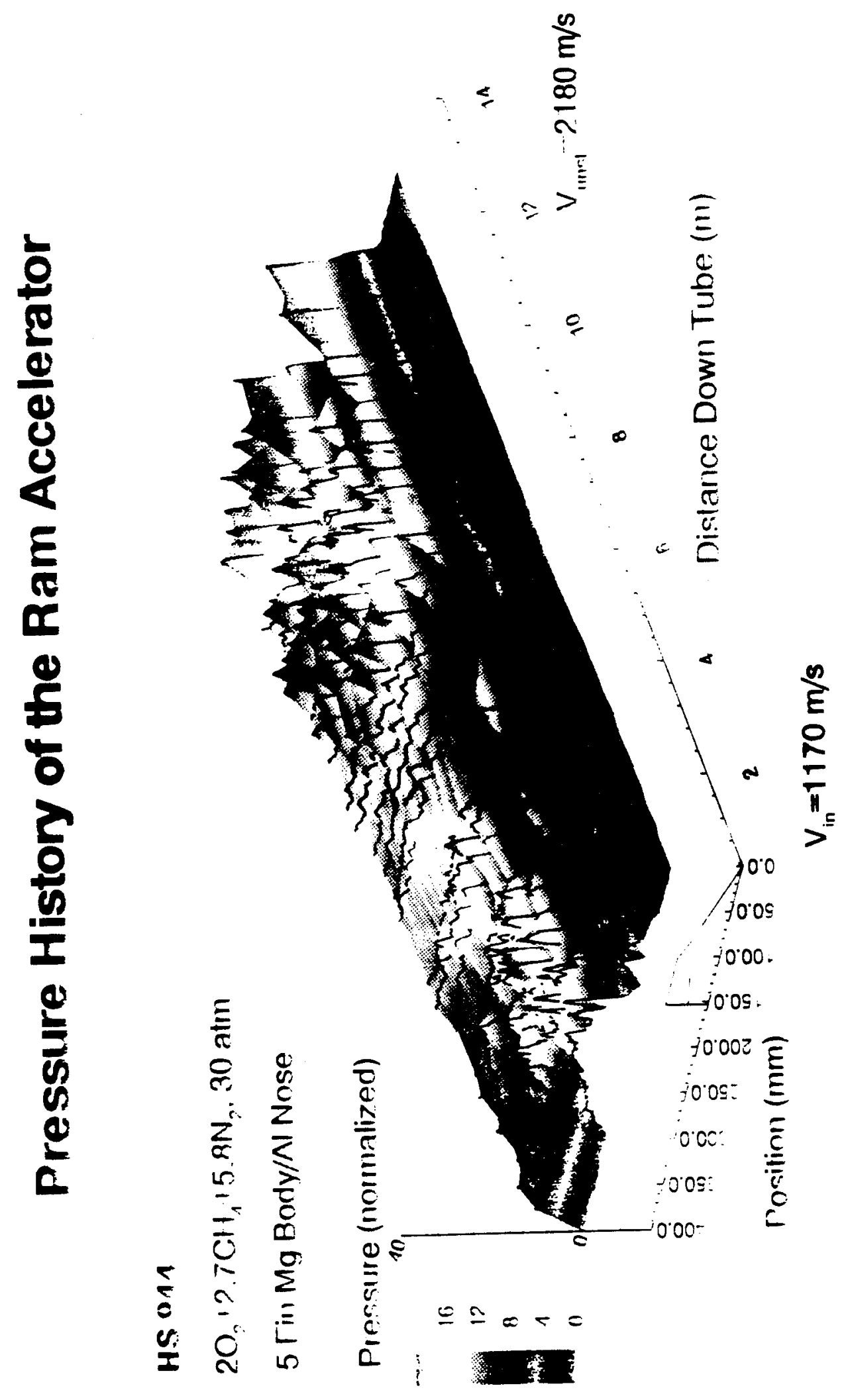




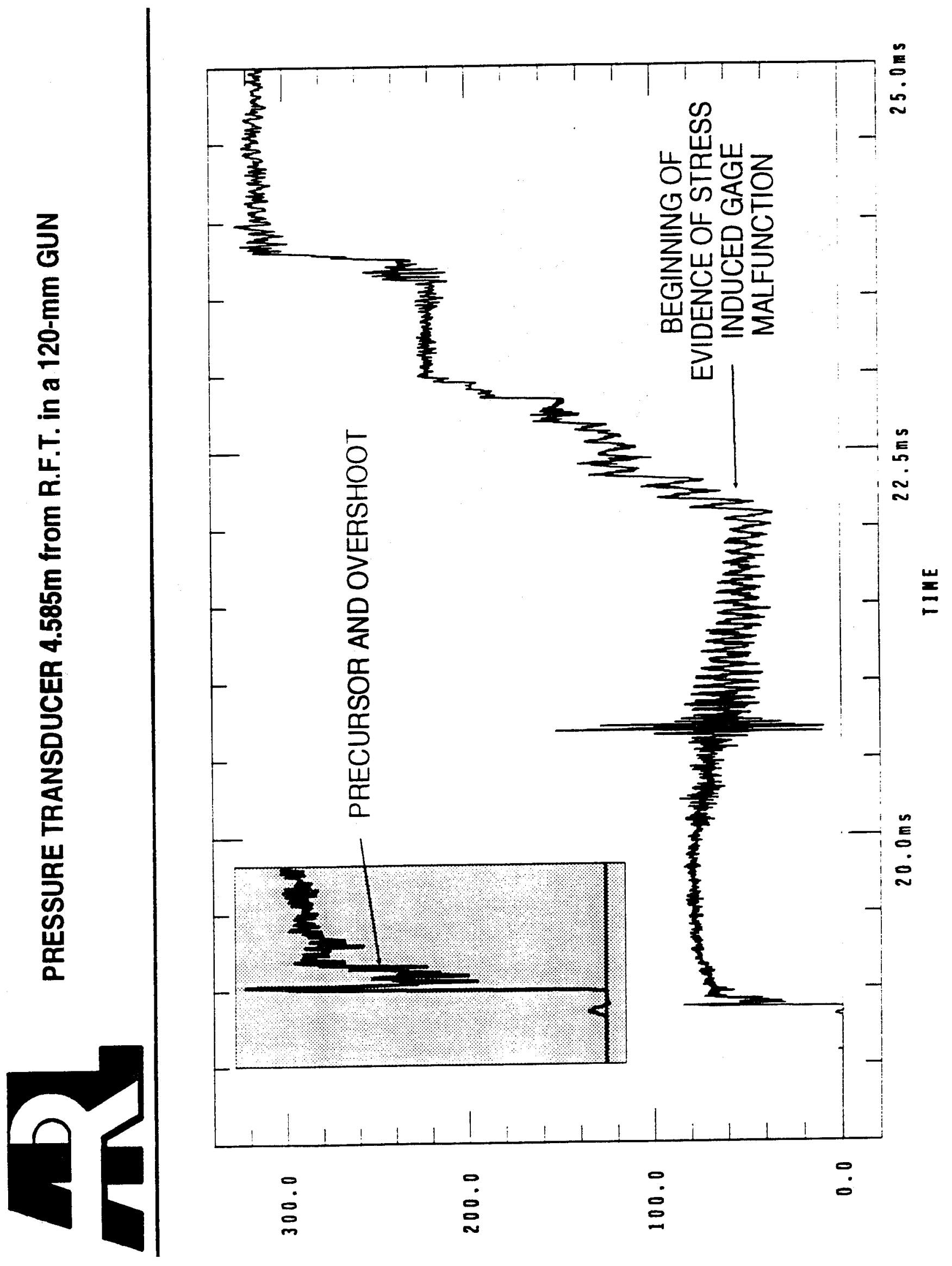




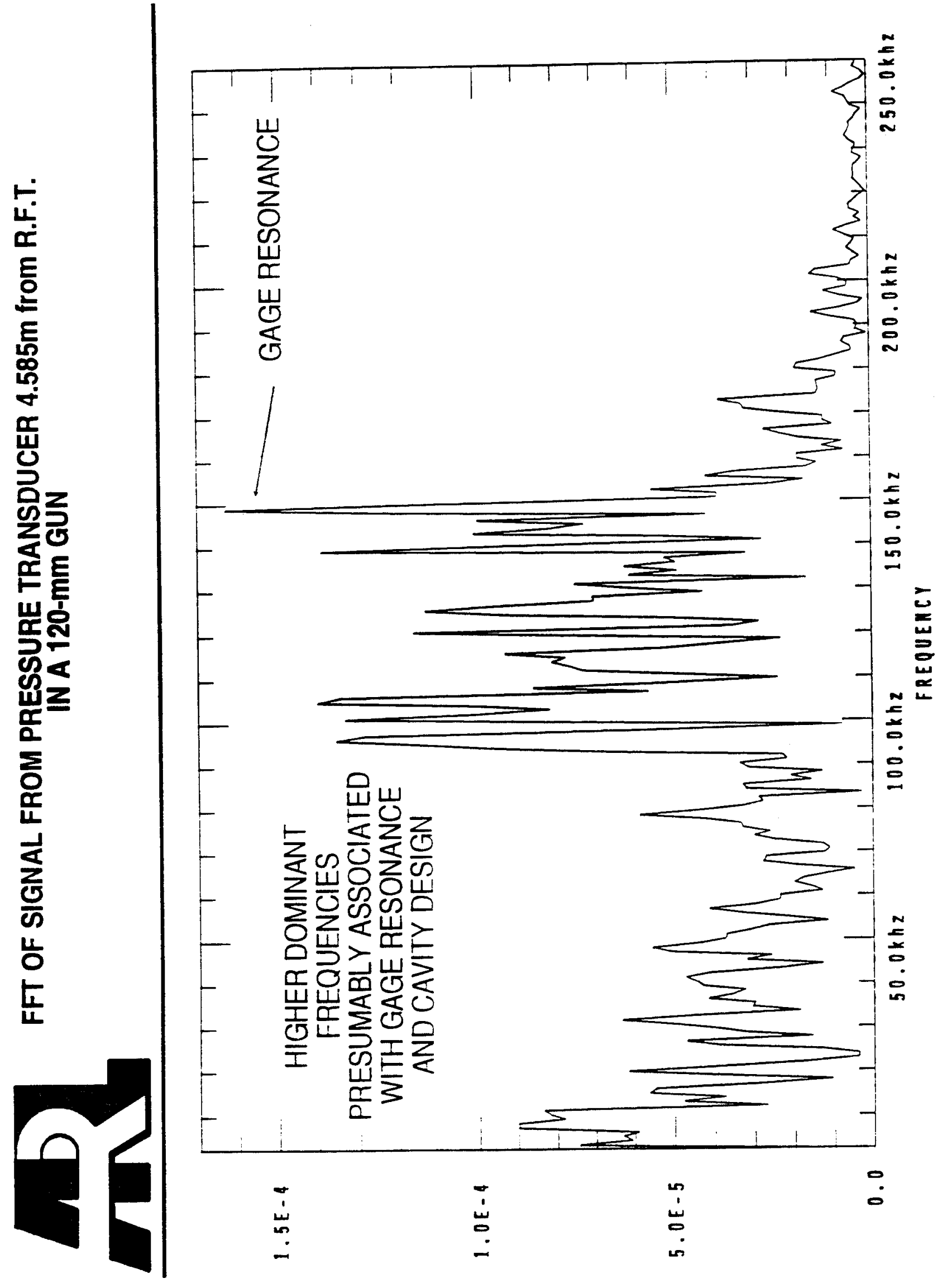




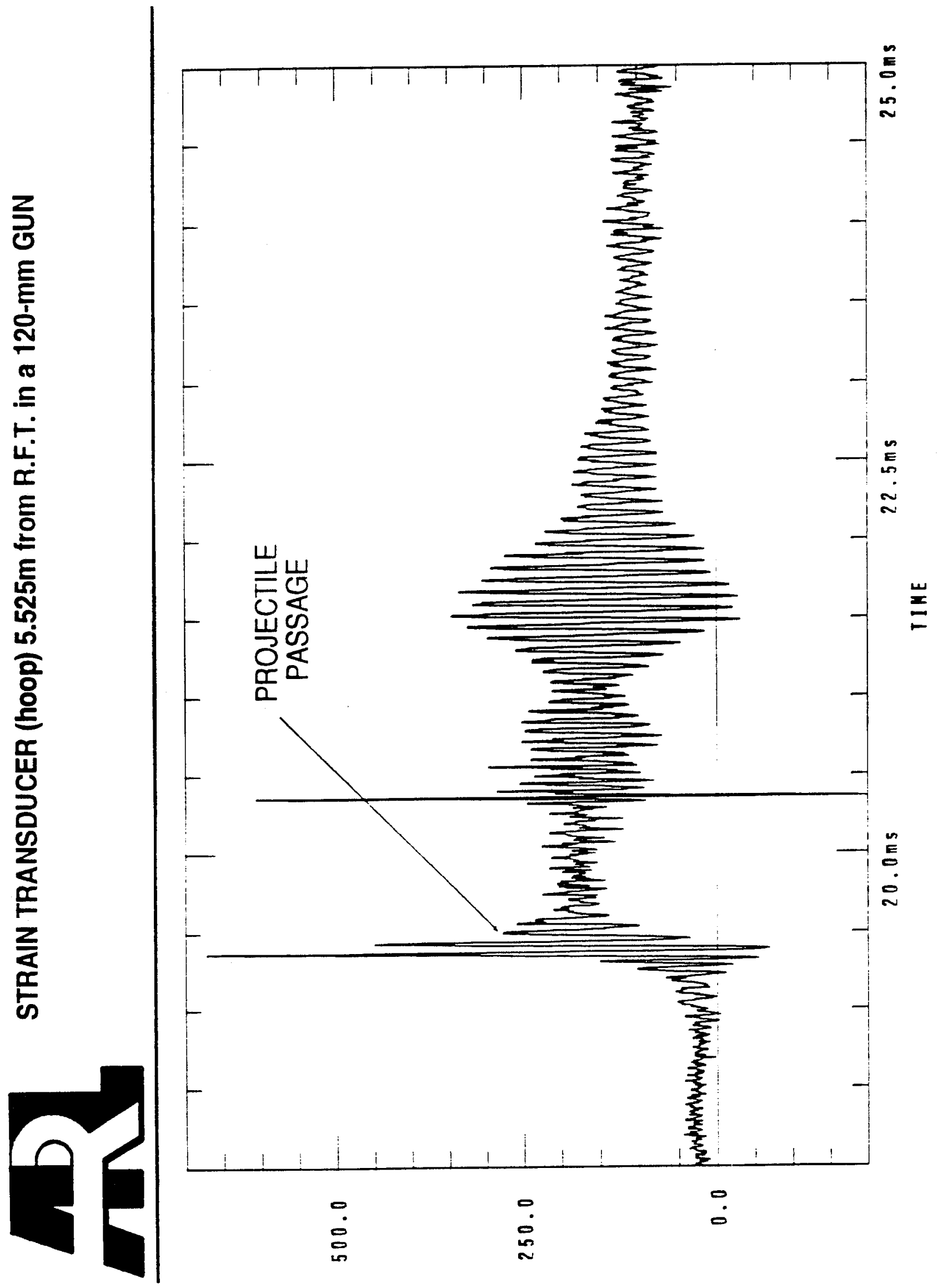




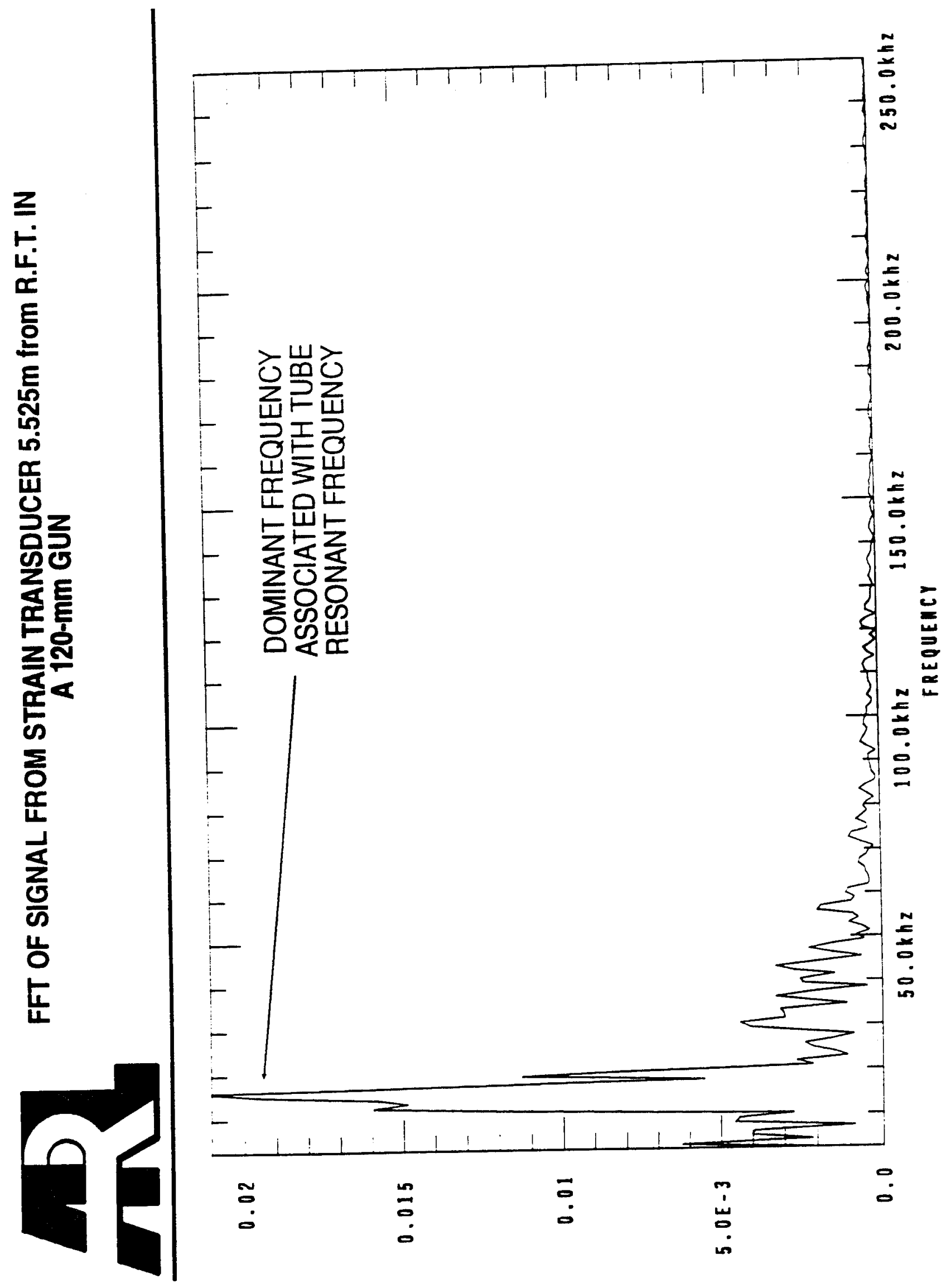




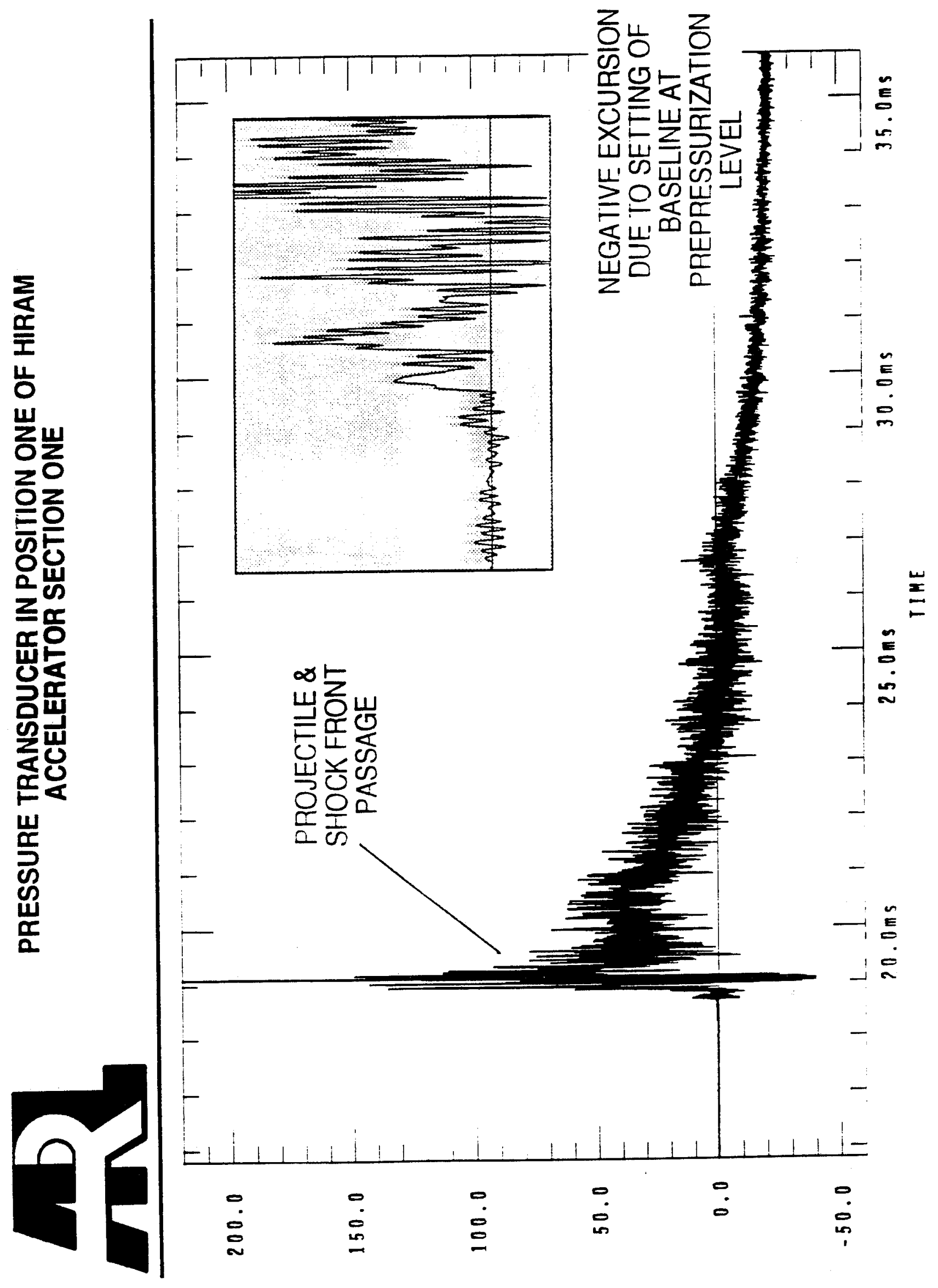




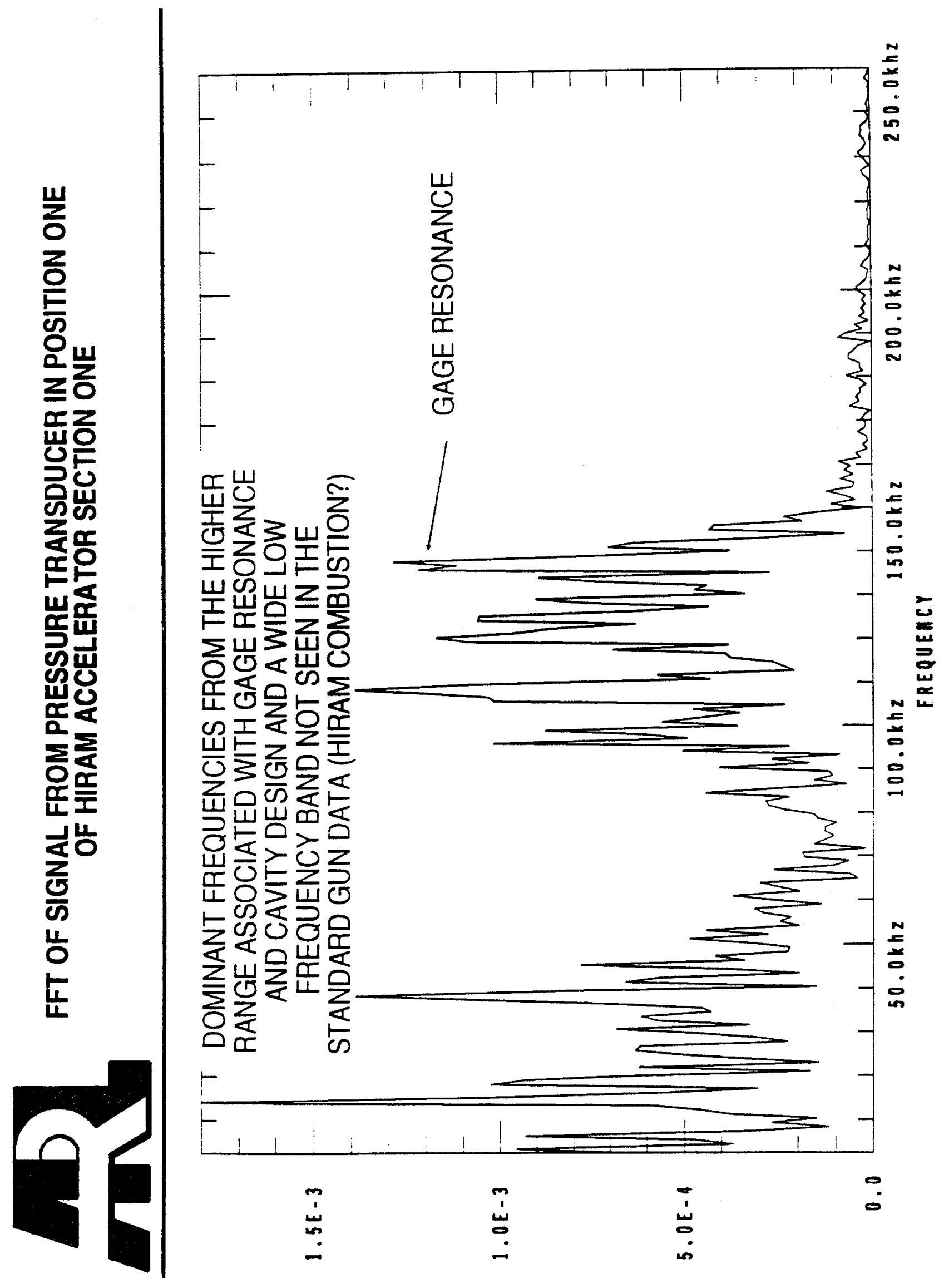




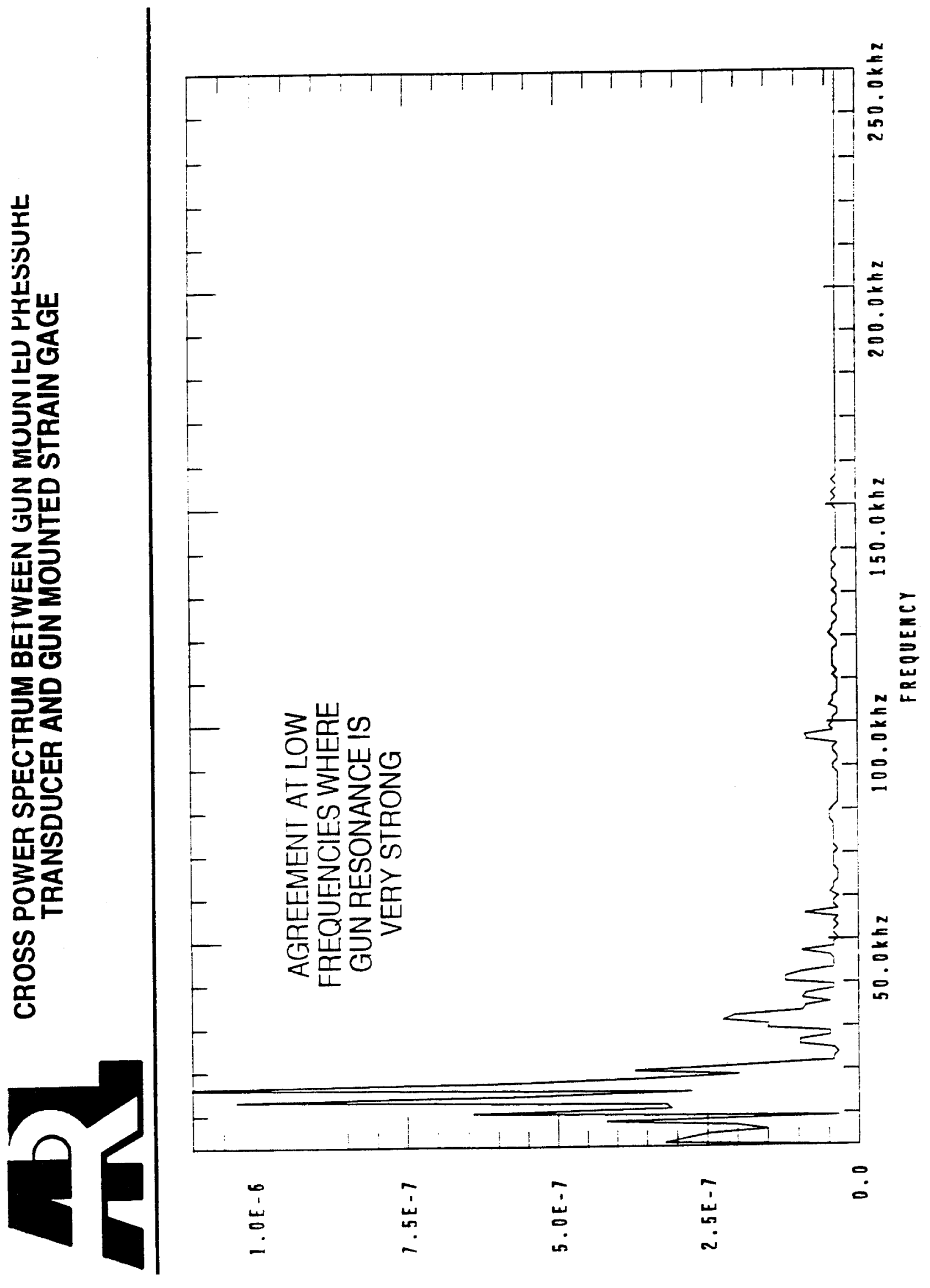




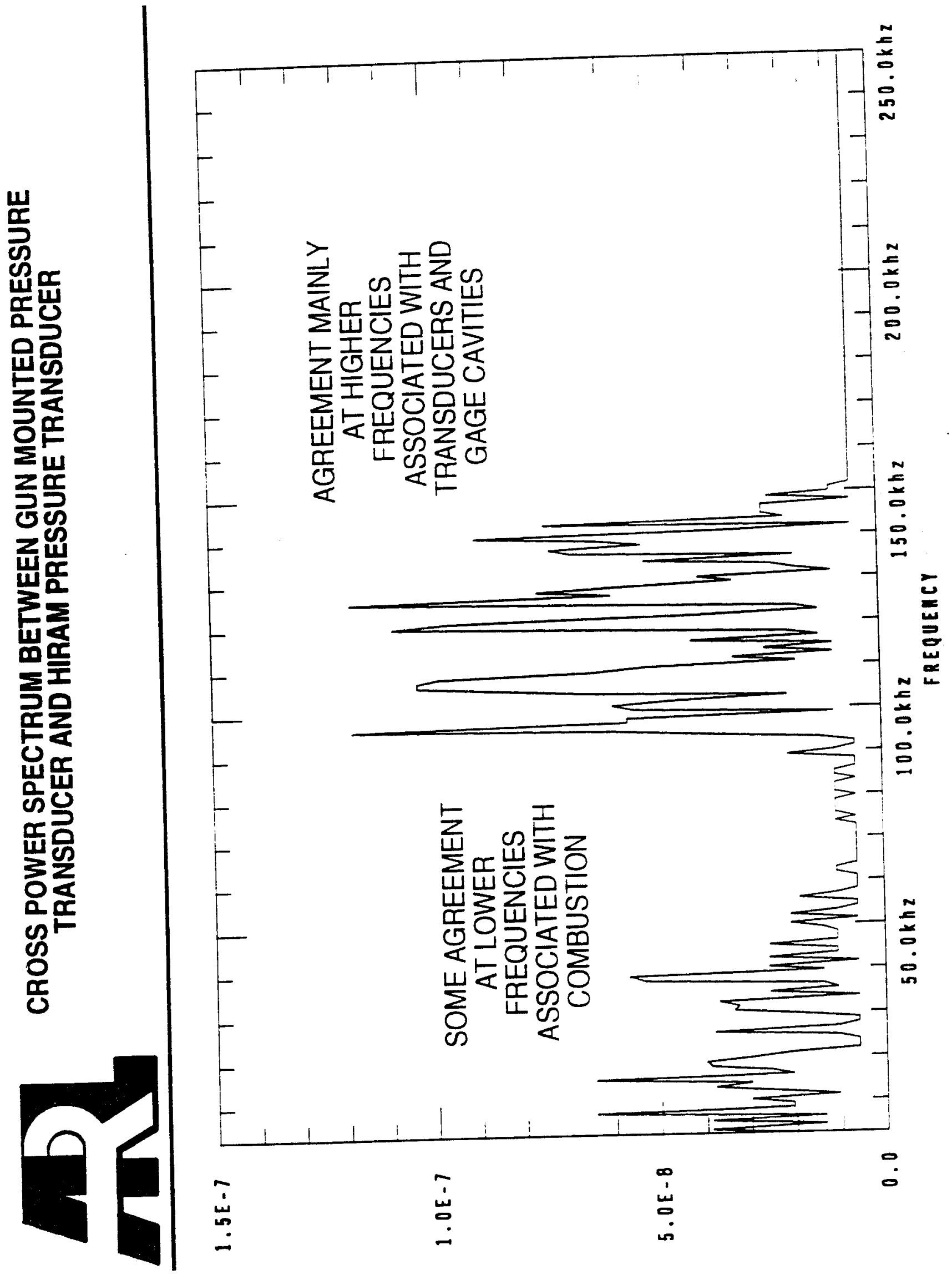




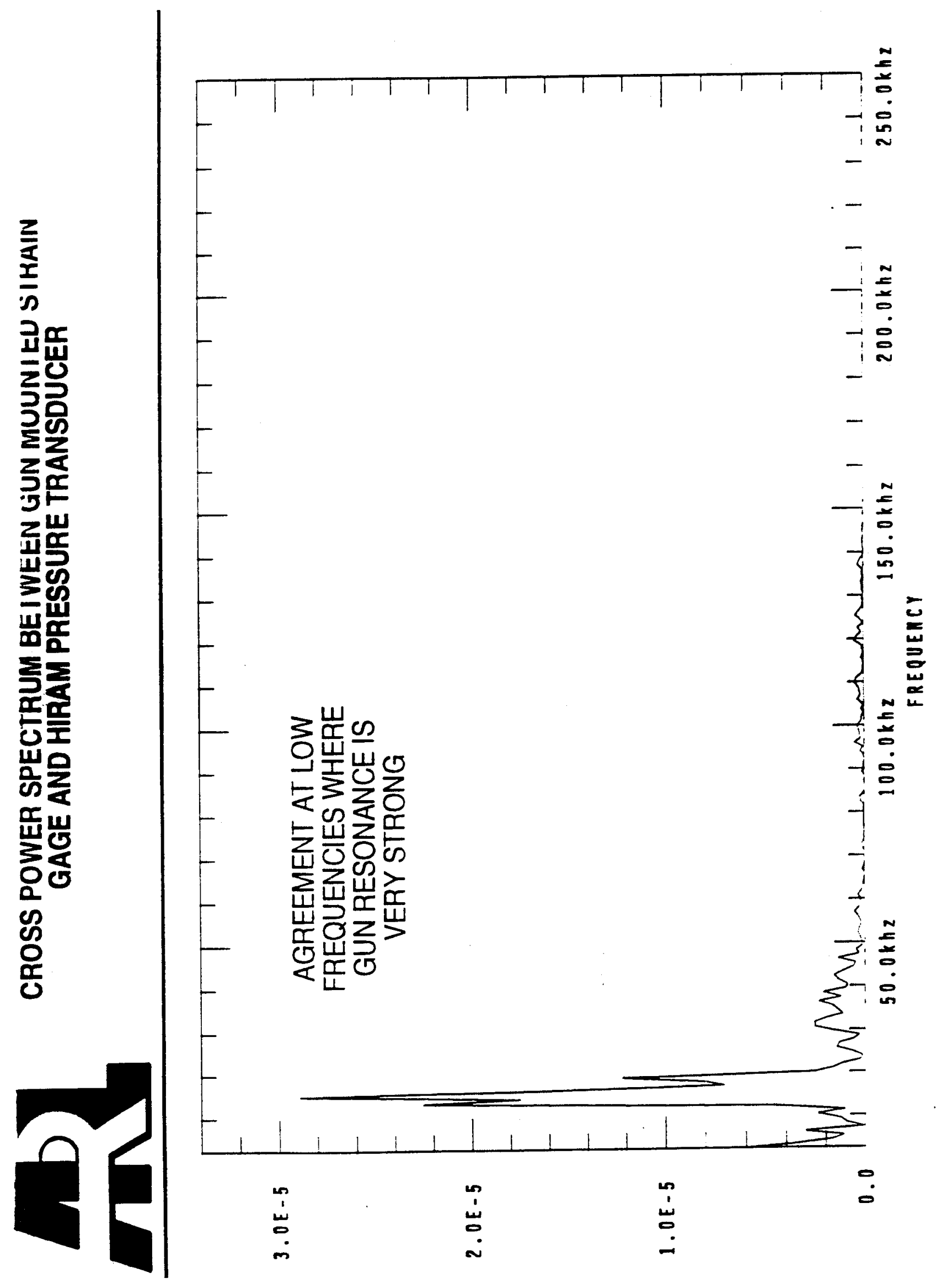




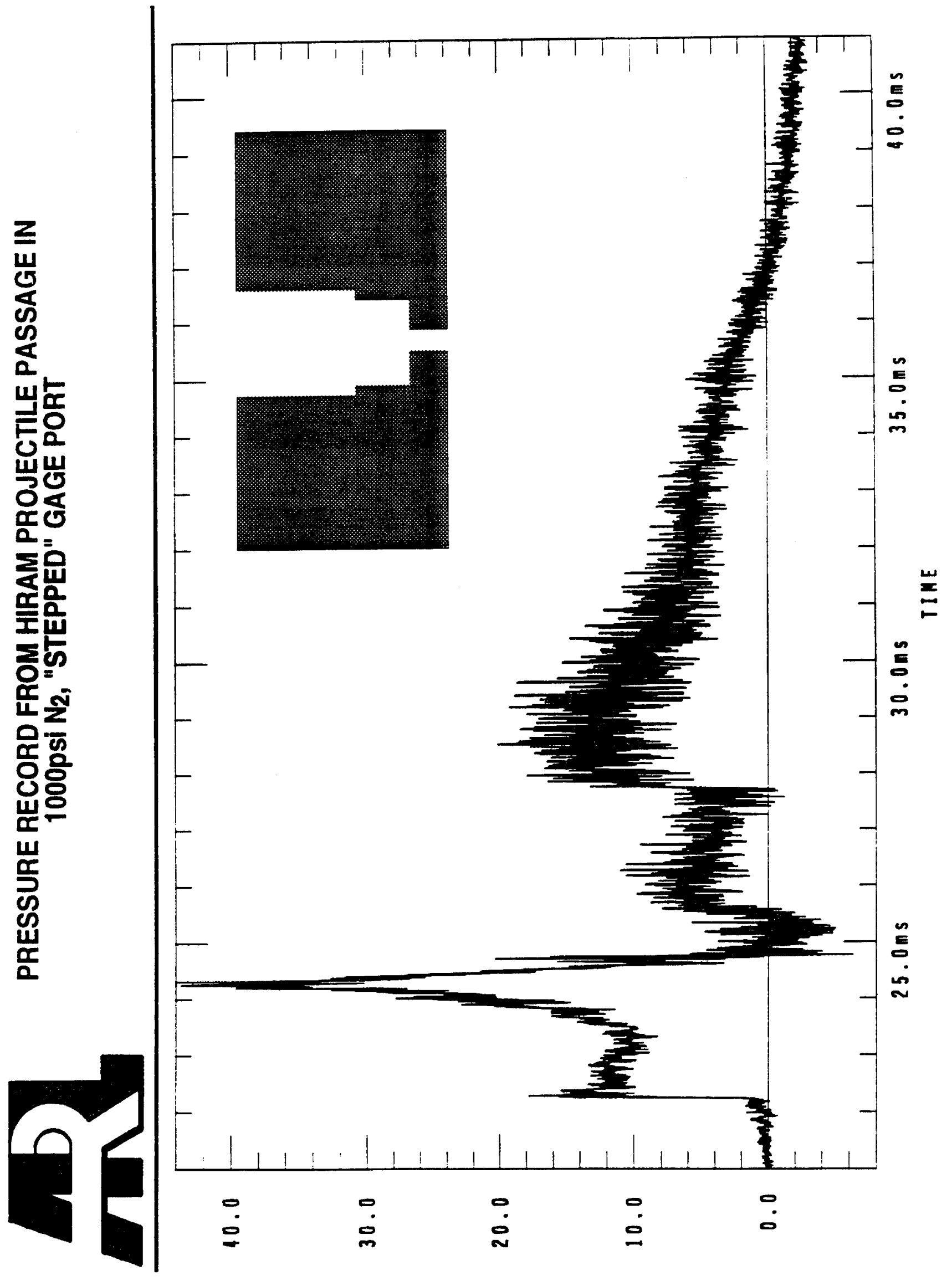




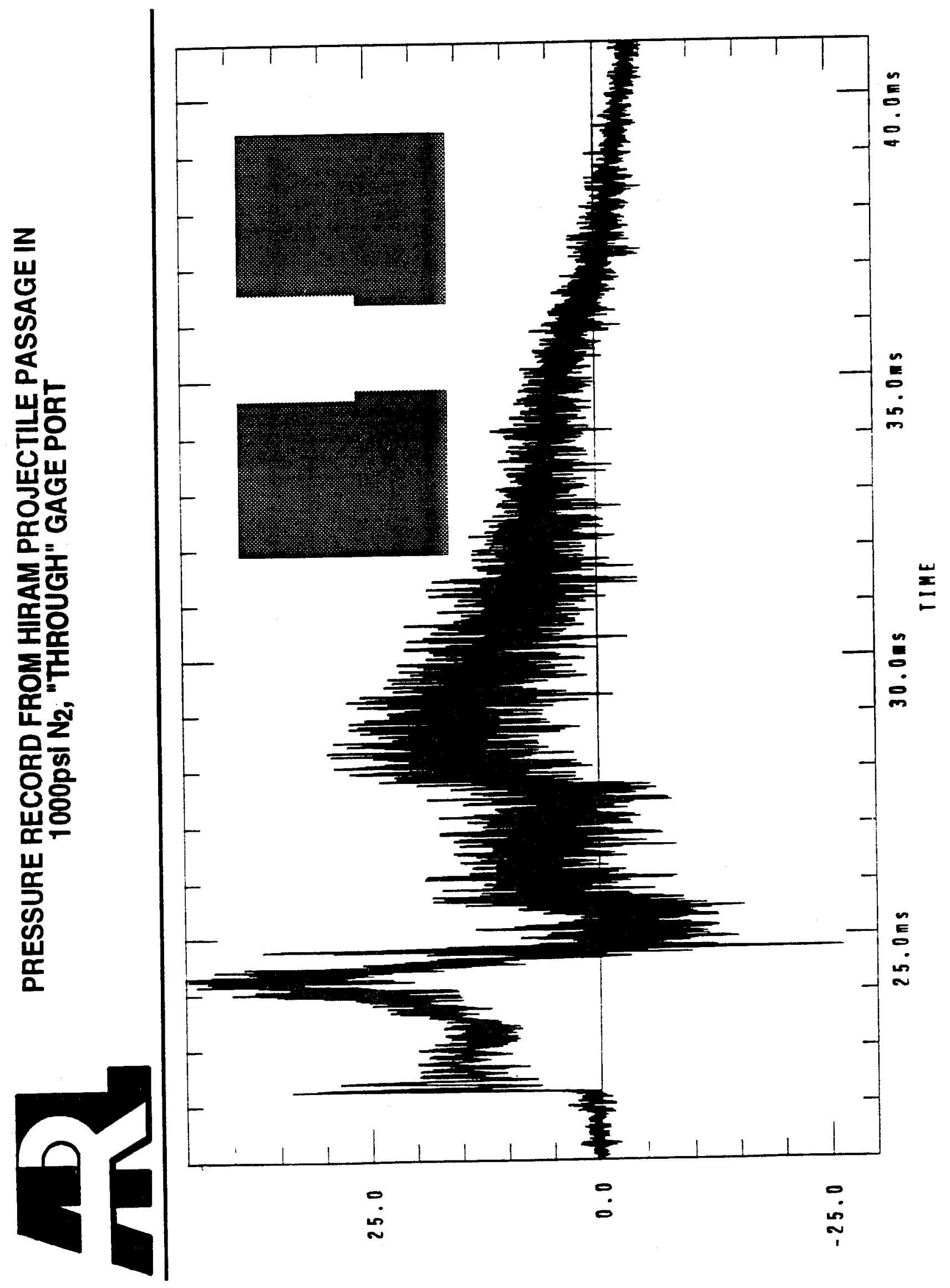




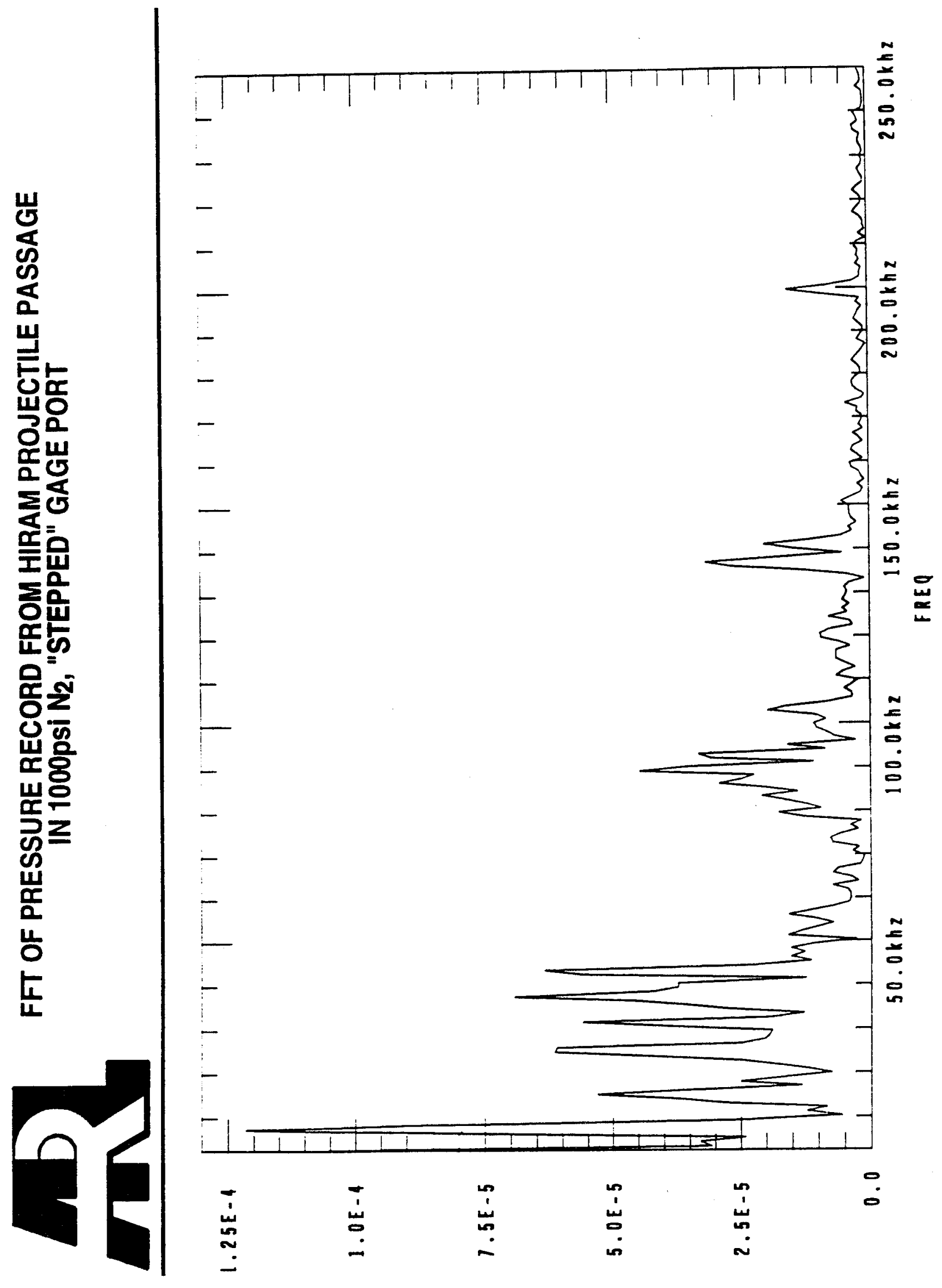




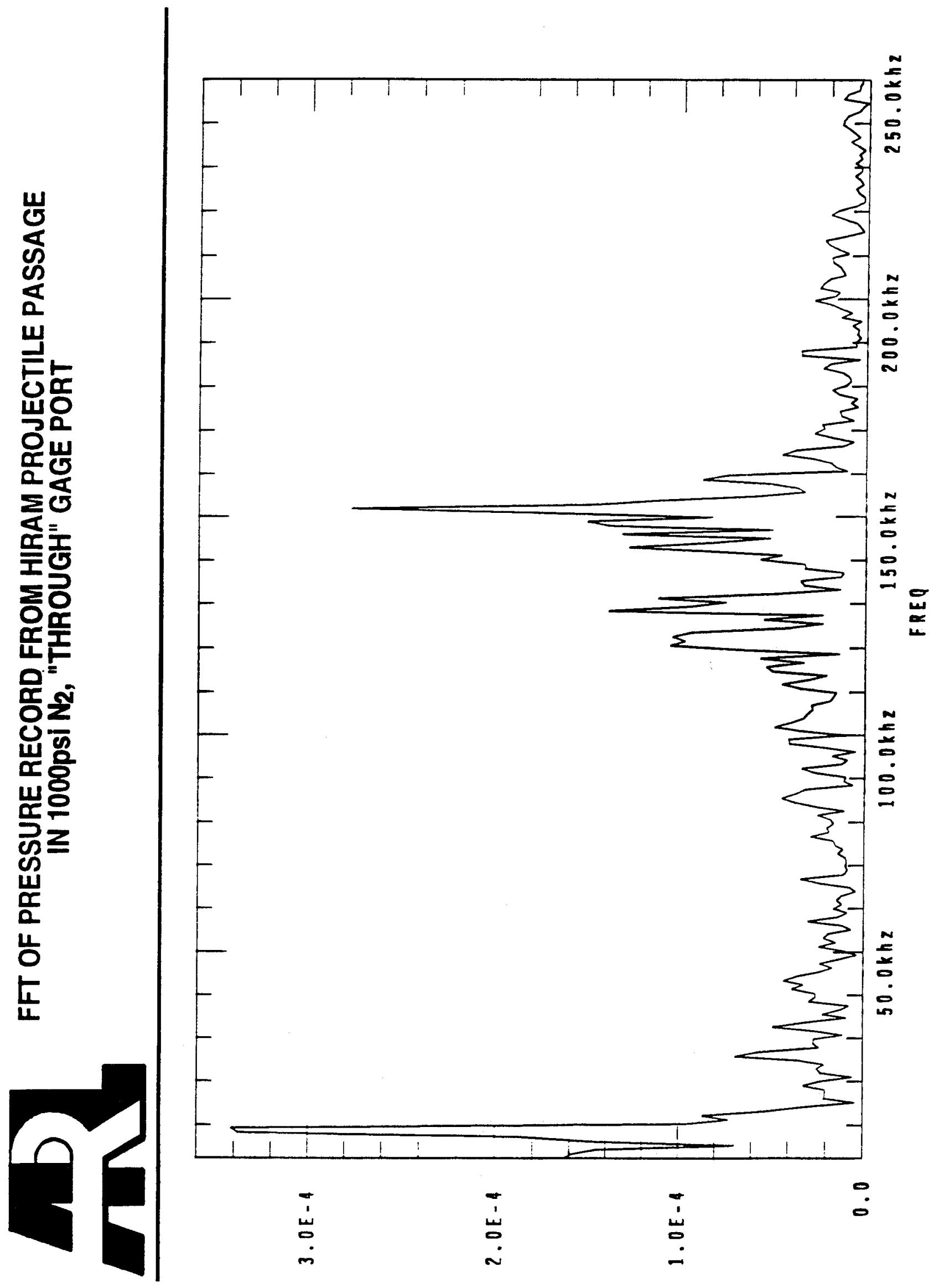




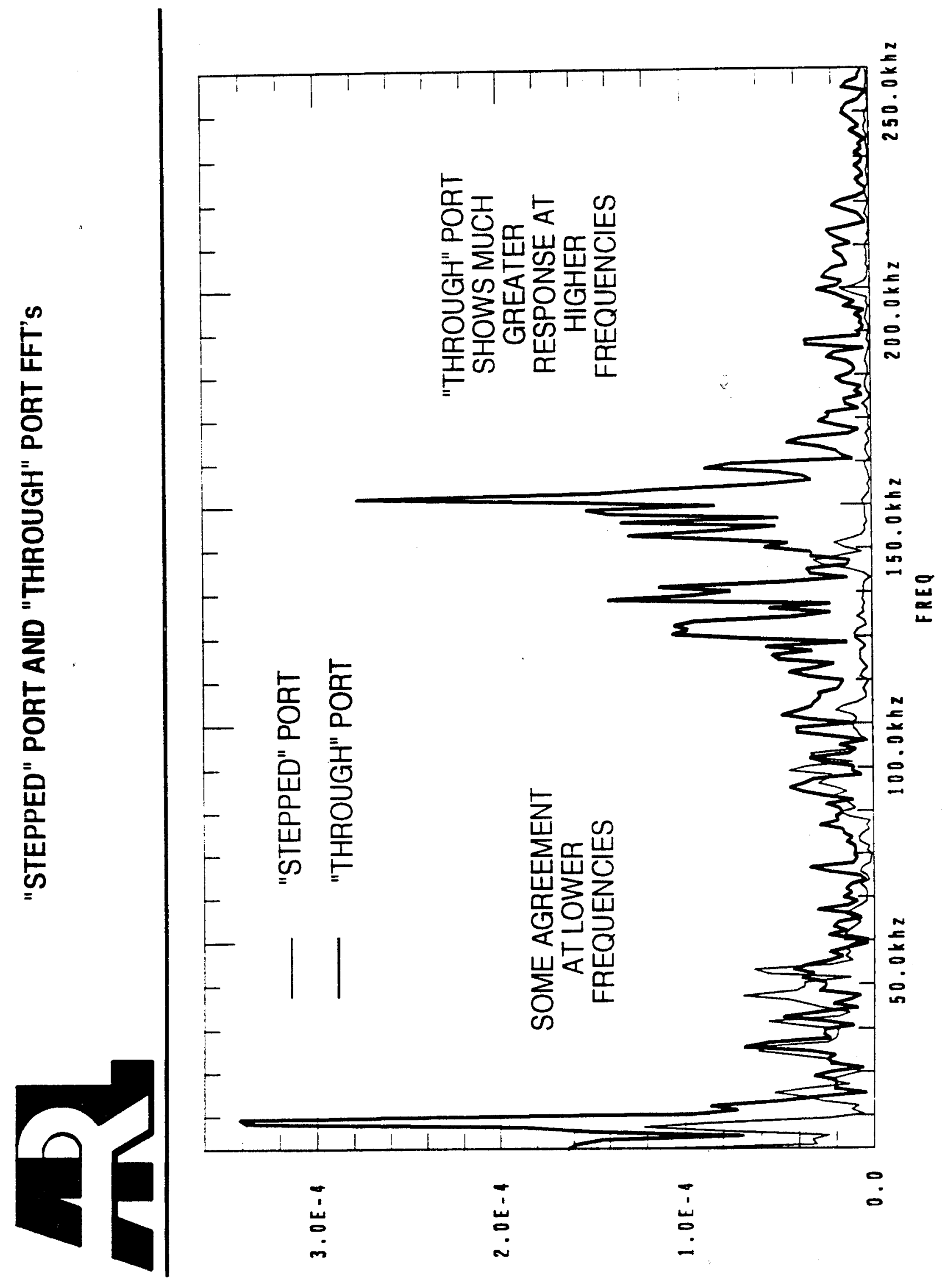




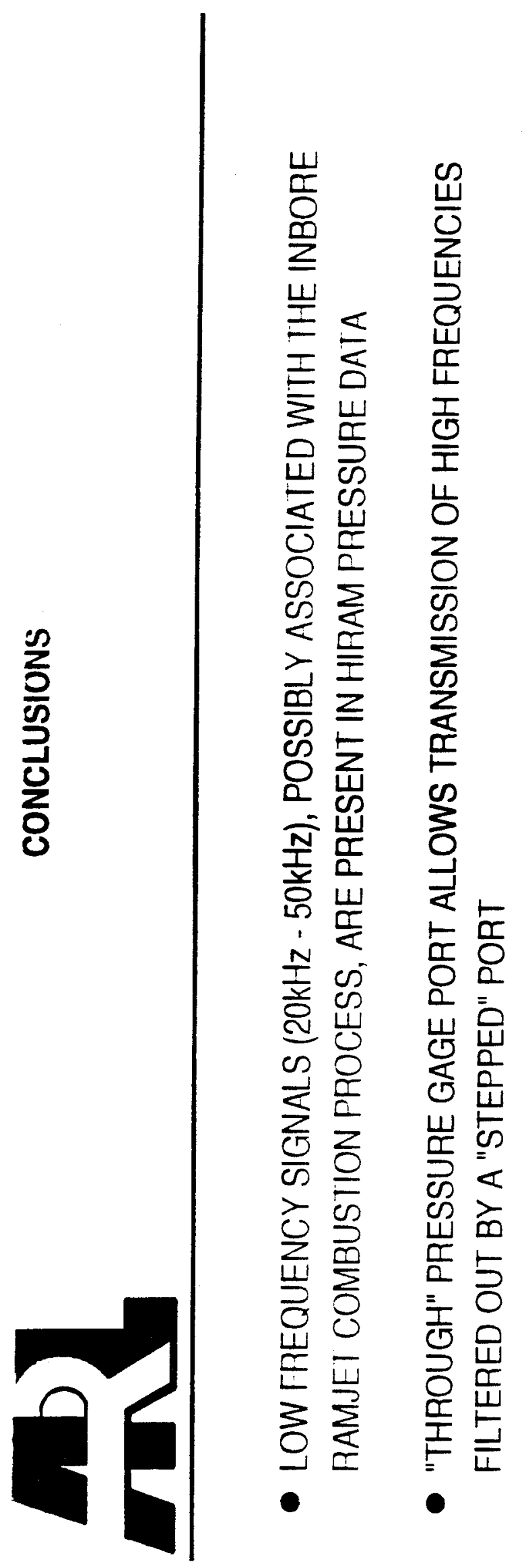




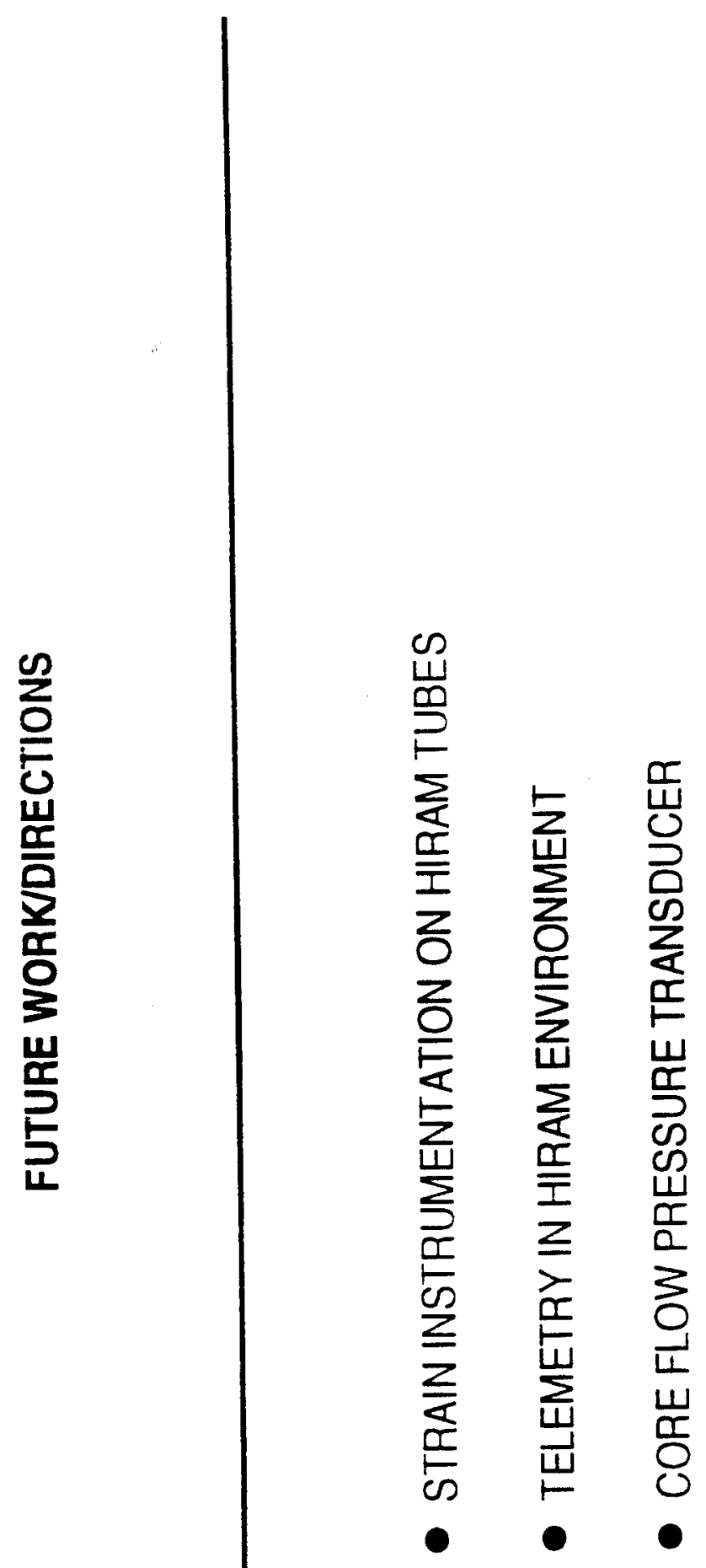


INTENTIONALLY LEFT BLANK. 
APPENDIX F:

PRESENTATION - "AN OPTICAL PRESSURE GAUGE FOR HIGH SPEED MEASUREMENTS IN THE 10-250 KBAR RANGE"

This Appendix is presented in its original form without editorial changes or comments. 
INTENTIONALLY LEFT BLANK. 

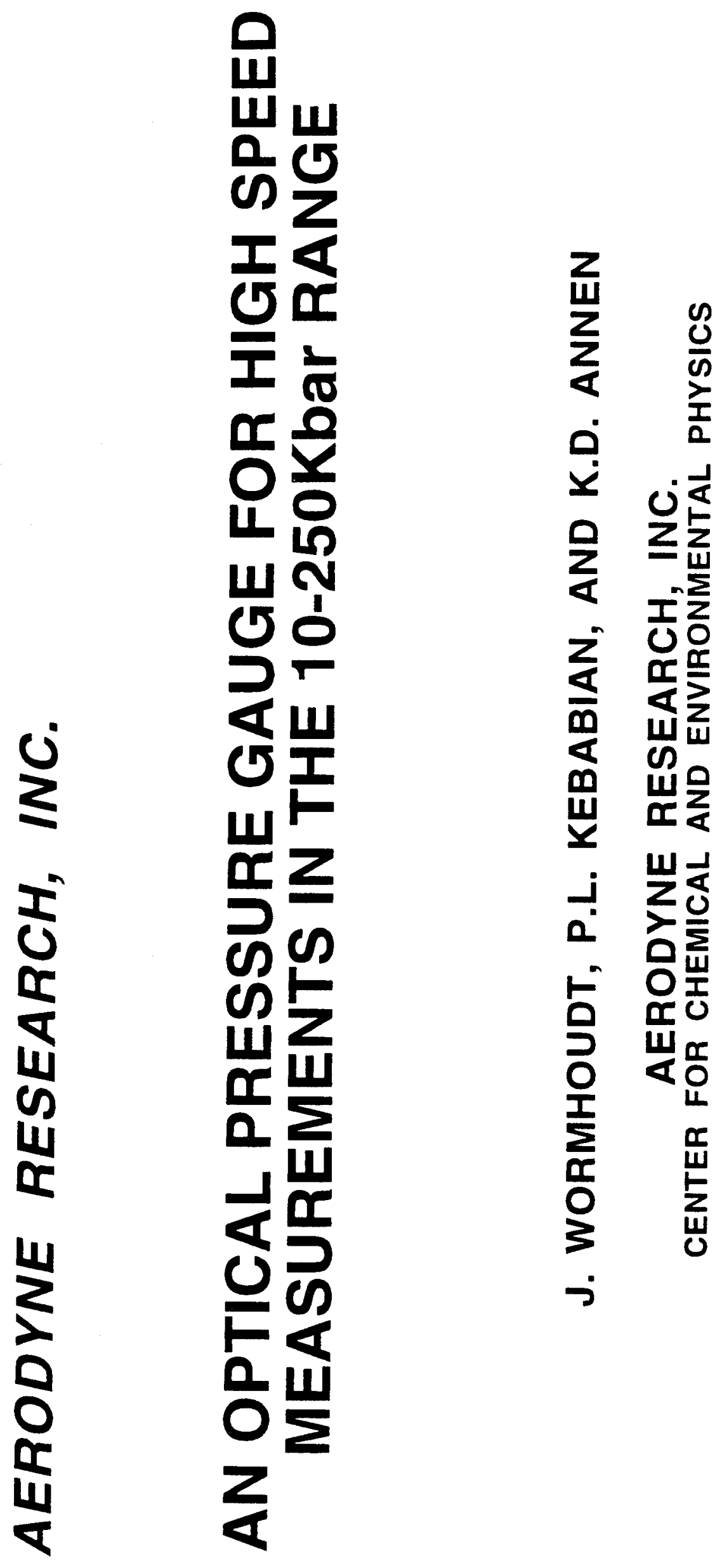

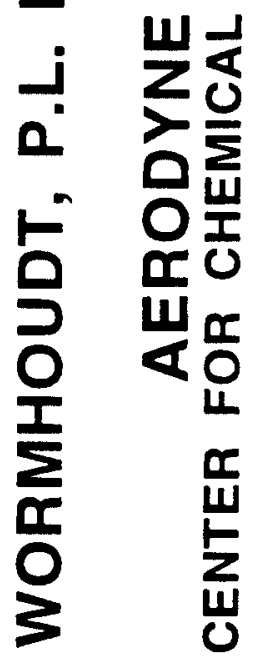

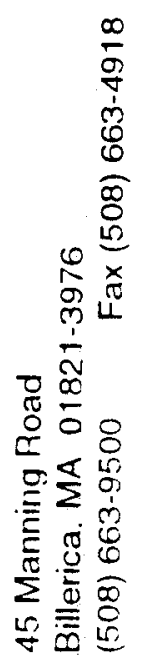




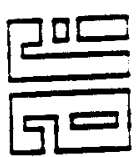

0
0
0
0
0

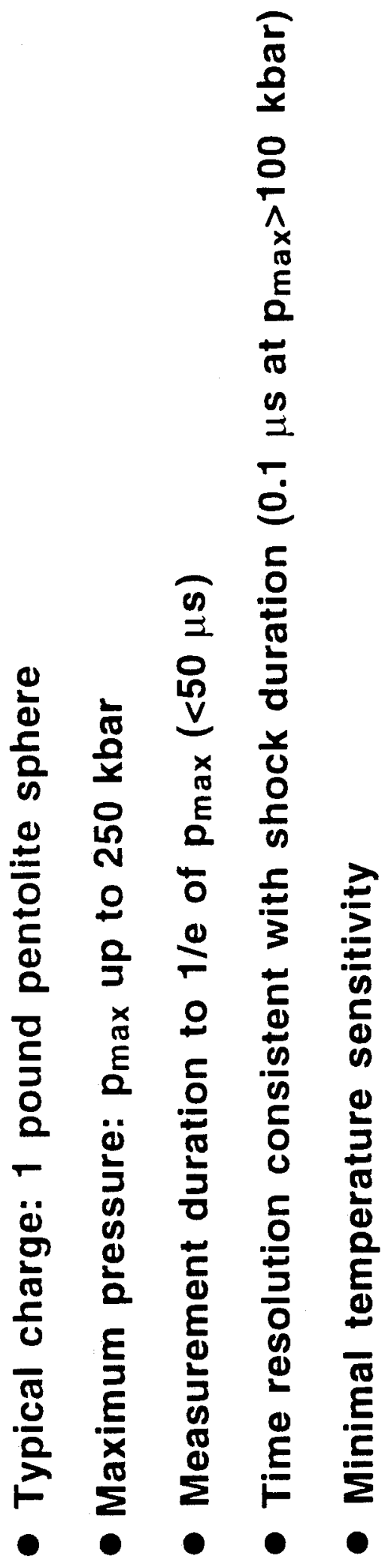


एव

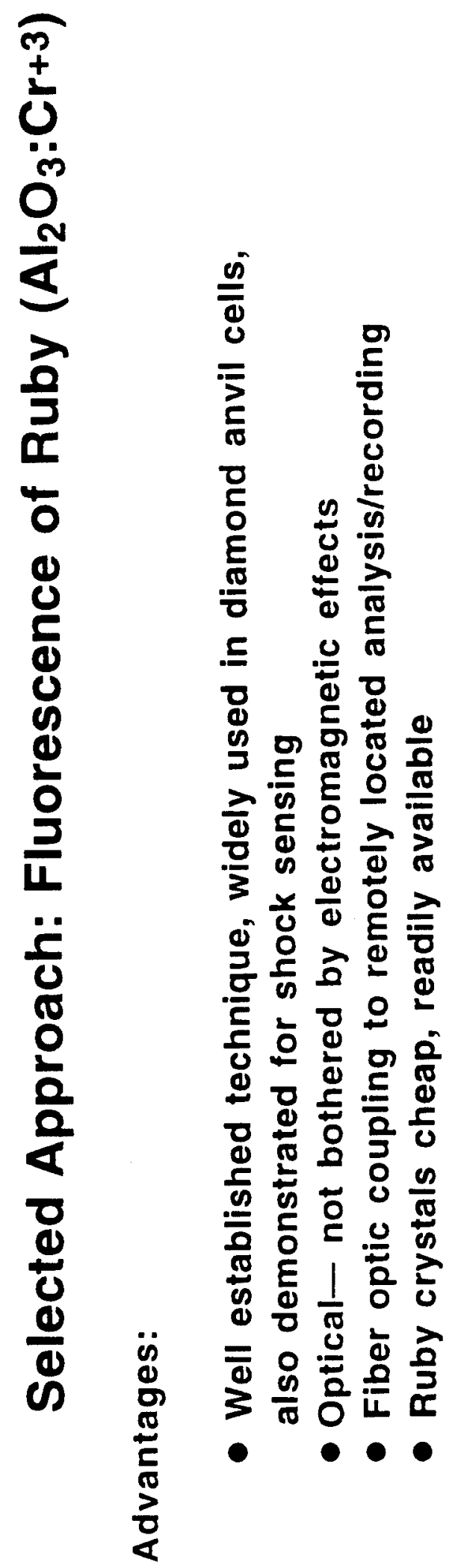

$\frac{5}{3}$

등

б

운 은

$\pm$

응은

흑

ส

동

$\stackrel{0}{0}$

은 $\frac{2}{2}$

(0) 워

는 중

可!

중

$\pm \frac{1}{\alpha}$ in

ठ

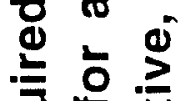

궁을

닌 뜬

ㅌ

흥

305

응

ఏ

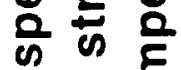

둥

르묘

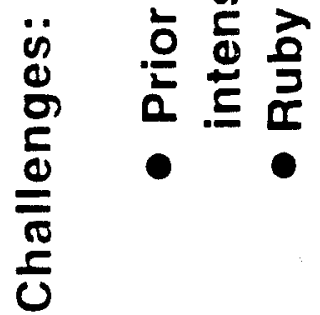




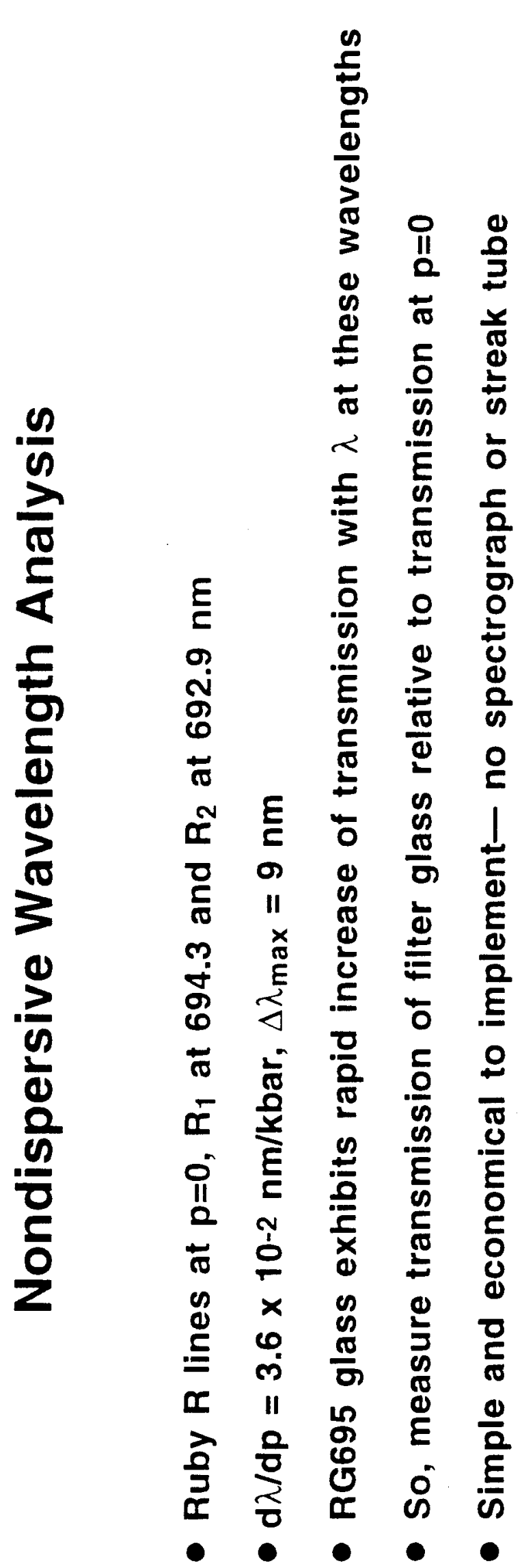


$\frac{1}{2}$

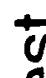

E

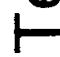

$\tau$

ส

क

$N$

$\frac{\pi}{\pi}$

$\frac{5}{4}$

둘

일

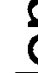

응

品

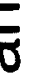

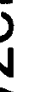

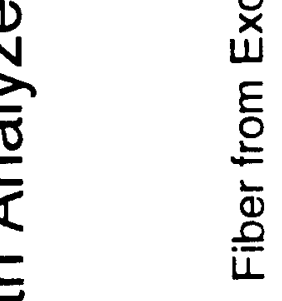

$\sum_{3}^{\infty}$

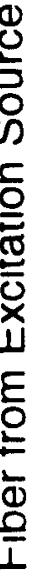

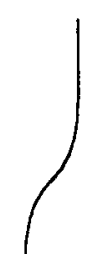

ธิ

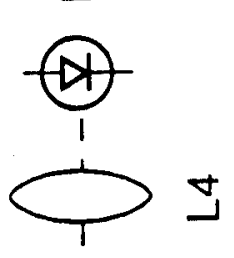

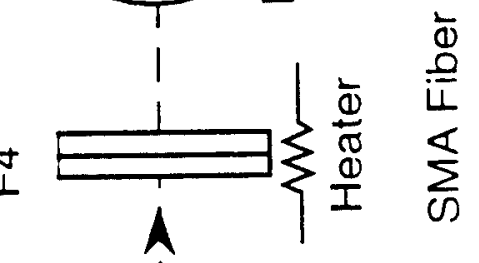
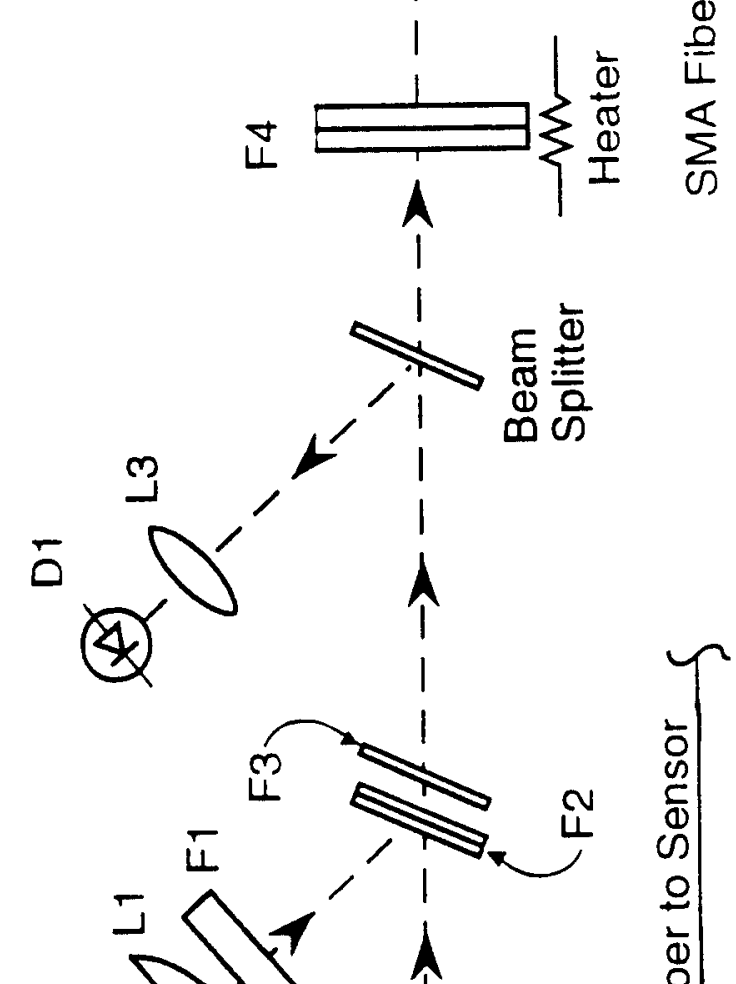

क्ष

현

$\sum^{\frac{\pi}{2}}$

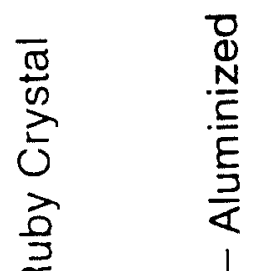

$\rightarrow W=\frac{\bar{d}}{\omega}$

L

Ny

N

N

$N$

$N$

Ny

$n^{K}$ 


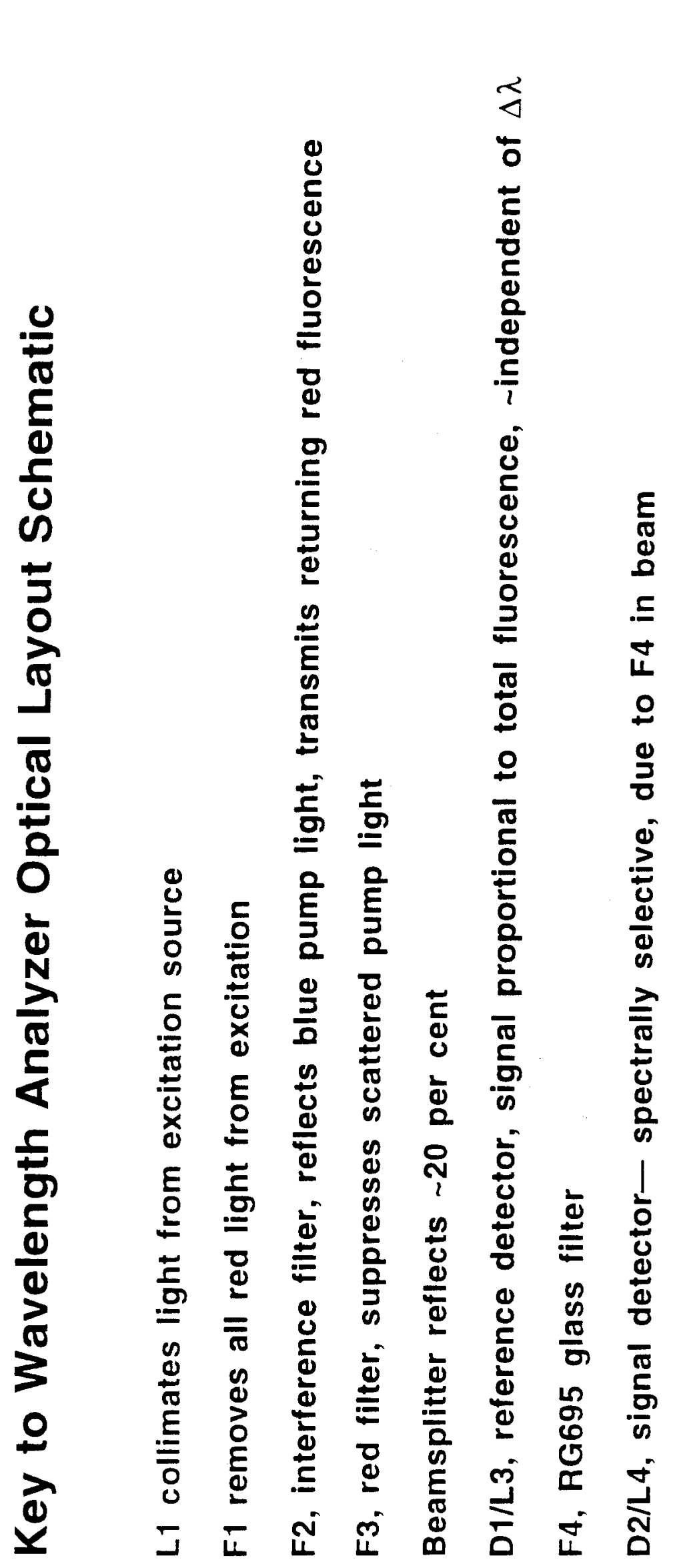




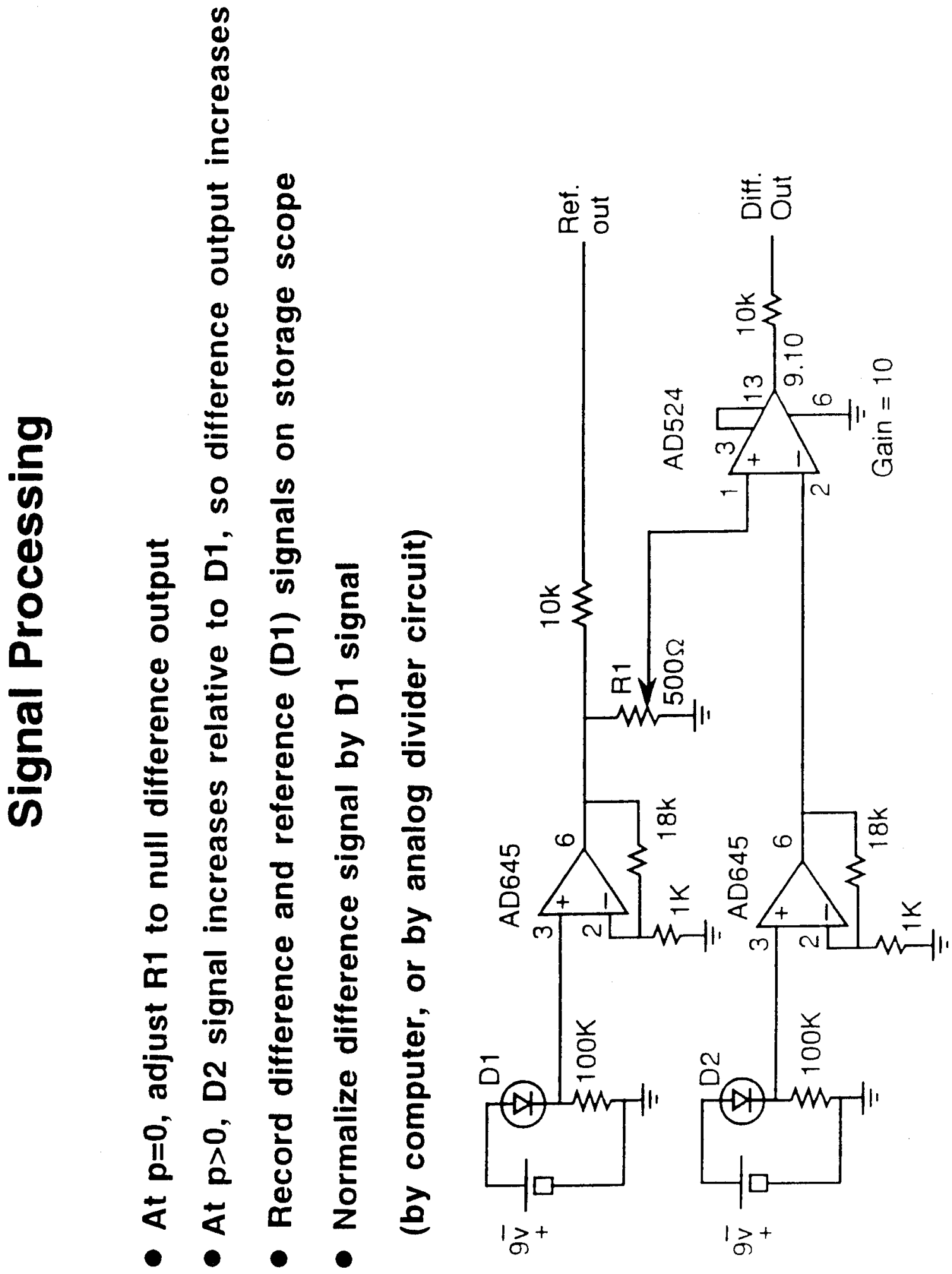




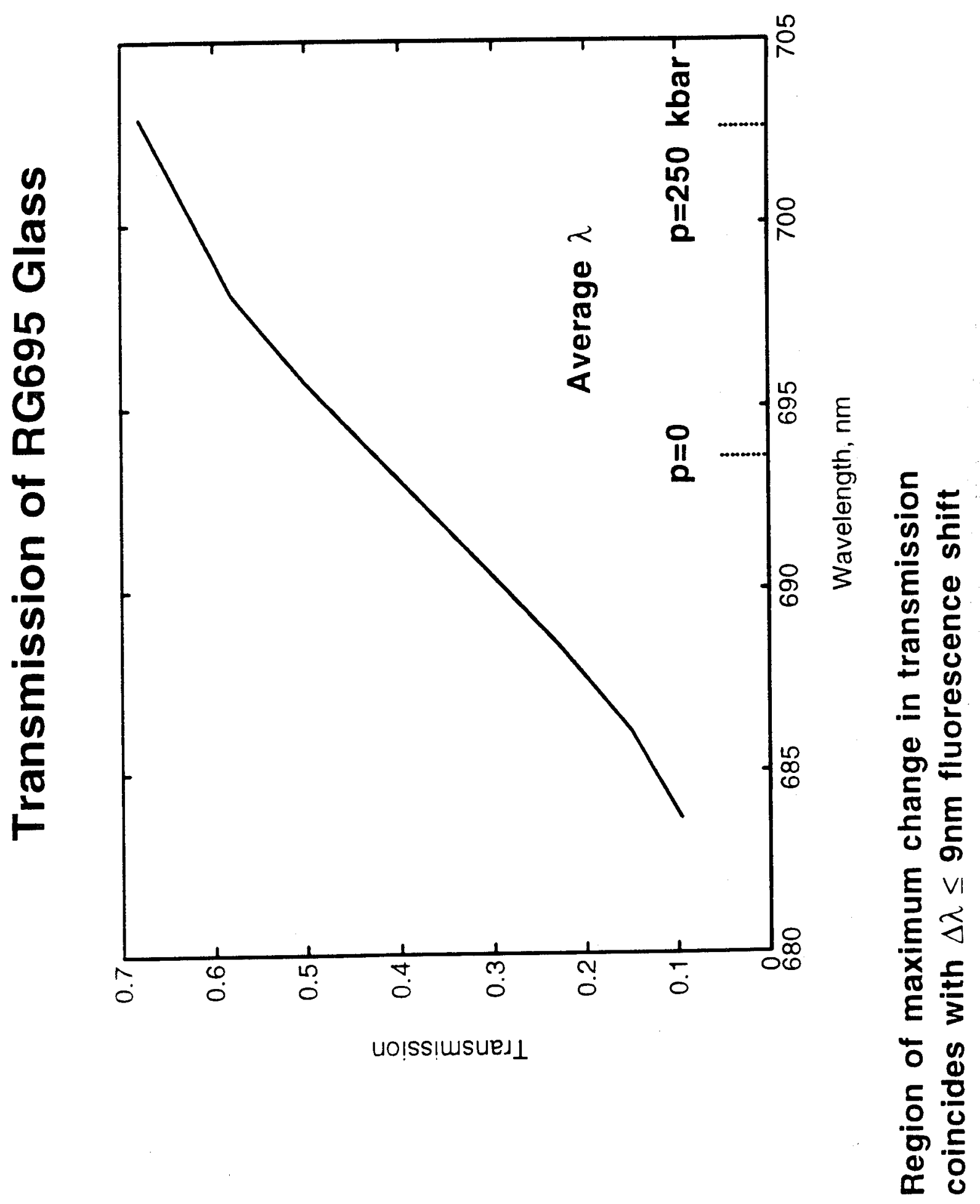




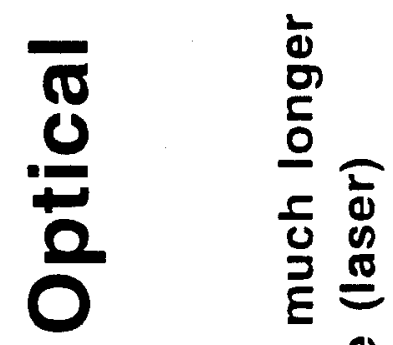

020 인

N 10 吉

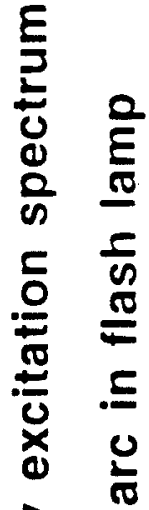

- 0 \&

(d) $12 \div$

단 $0 \frac{0}{5}$

U 0 E

14 \% 둥

E 01 은 훈

(1) $5 \frac{5}{0}$

E $E$ ठे है

(1) का क ह

10 11 동

$\geqslant 0$ ह

92 क

20 닌

20 क 잉

$5 \mathrm{~L} L \frac{2}{3} \frac{5}{0}$

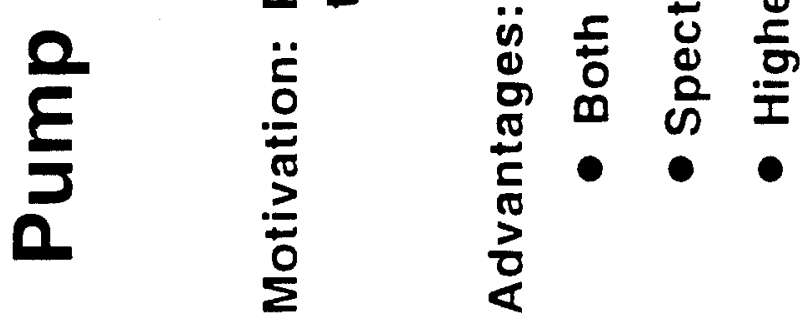

อั

$\underline{E}$

웅

을

$\sum_{0}^{\frac{1}{0}}$

응 는

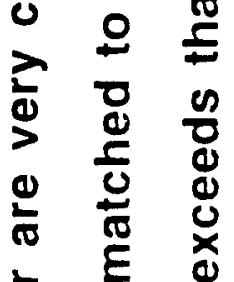

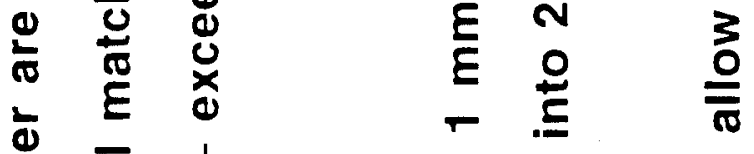

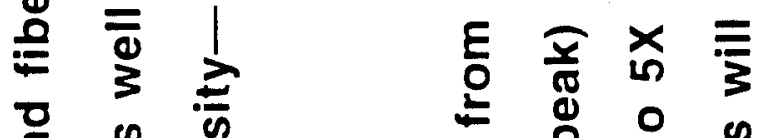

है $\cong \frac{\pi}{0}$

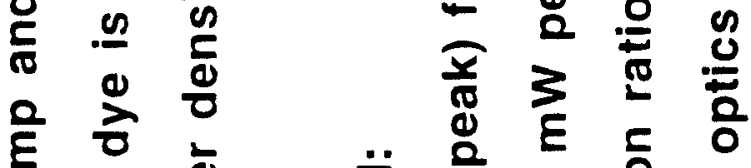

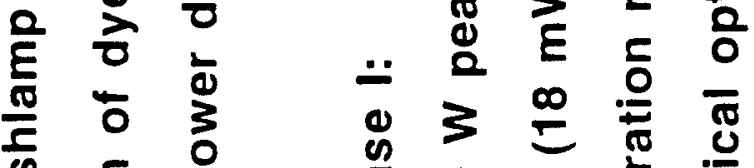

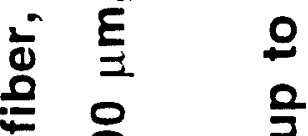

a $>E \pi$

음 9 ह

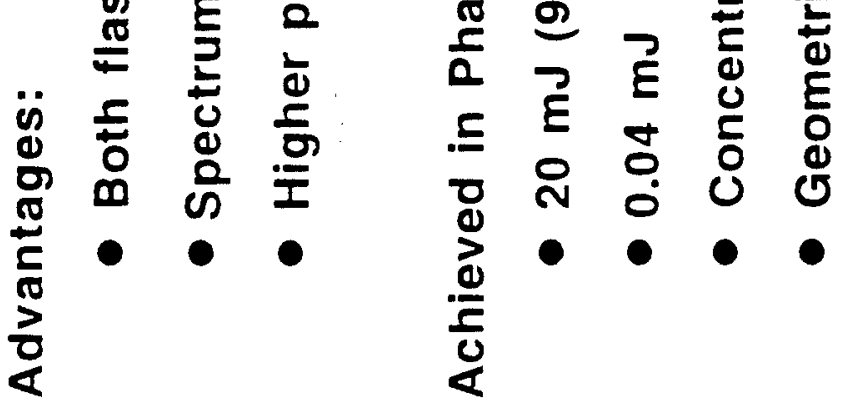




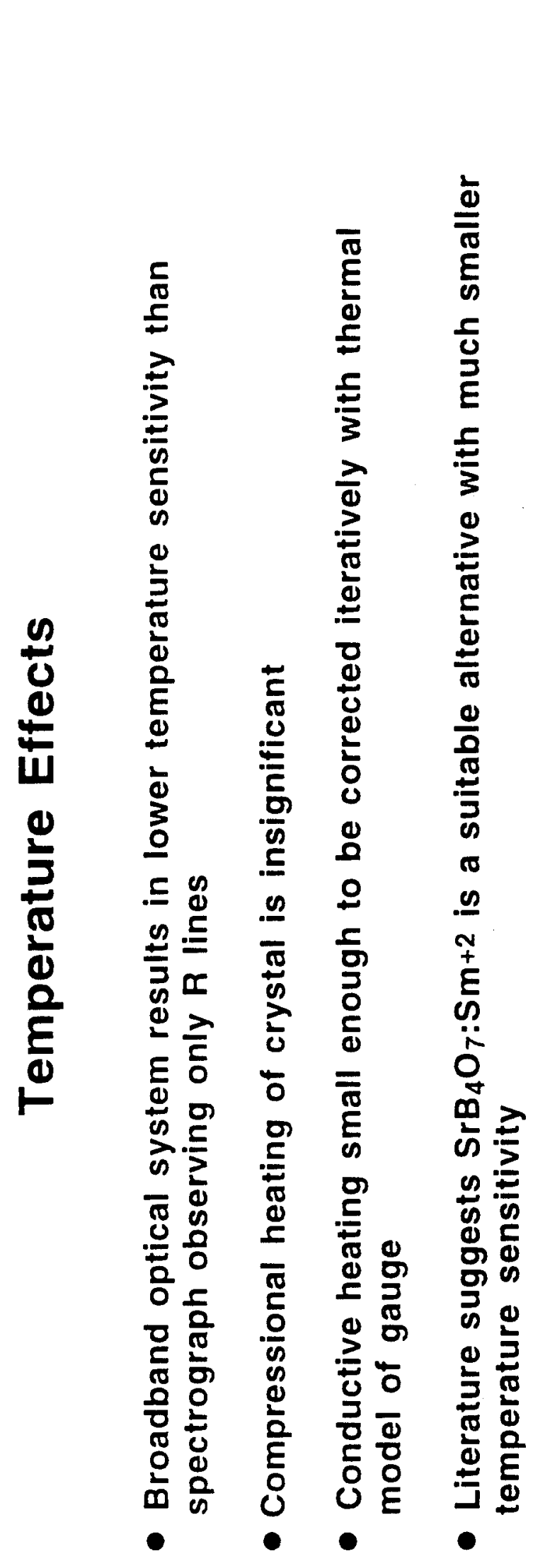




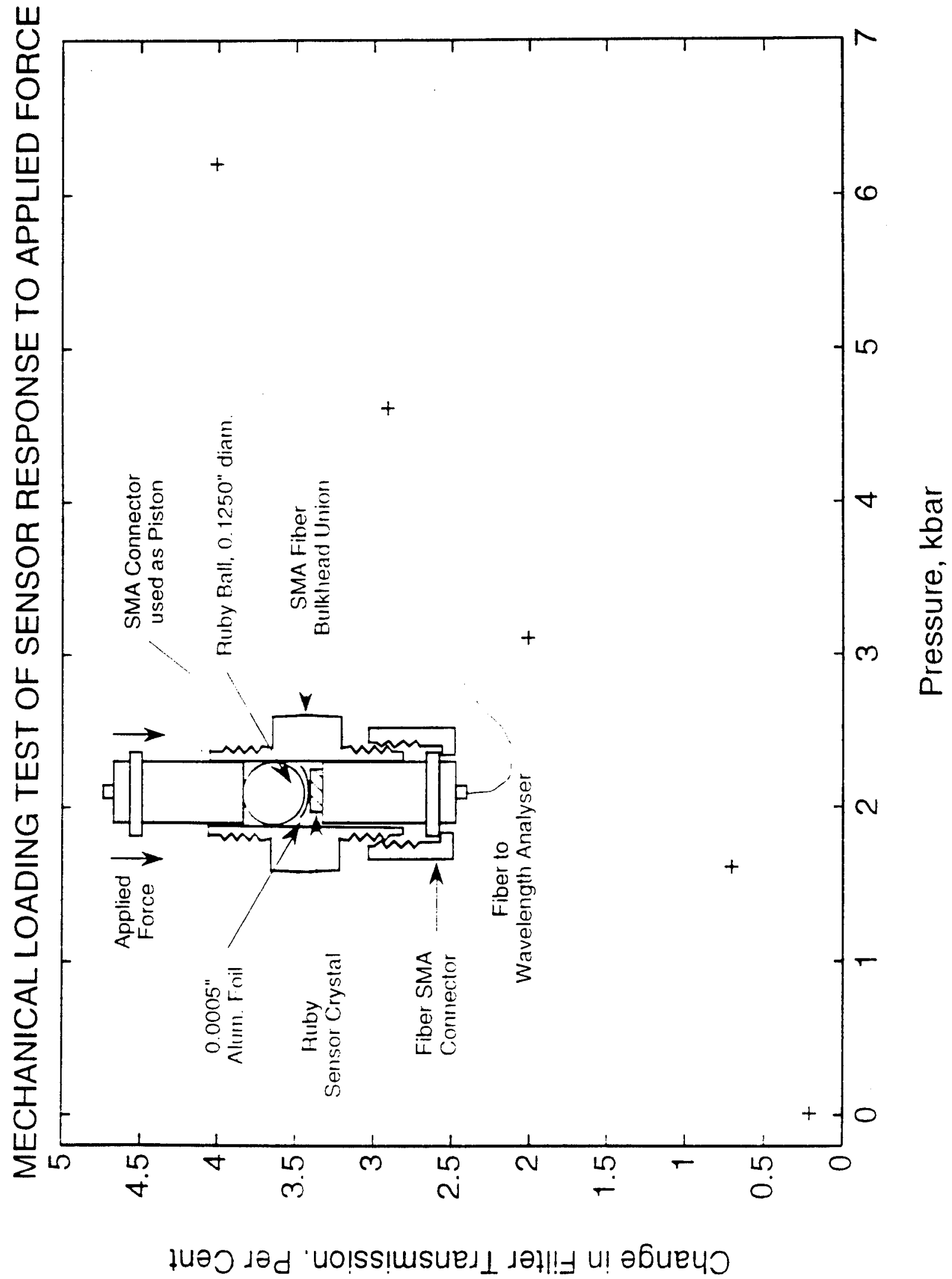


एव

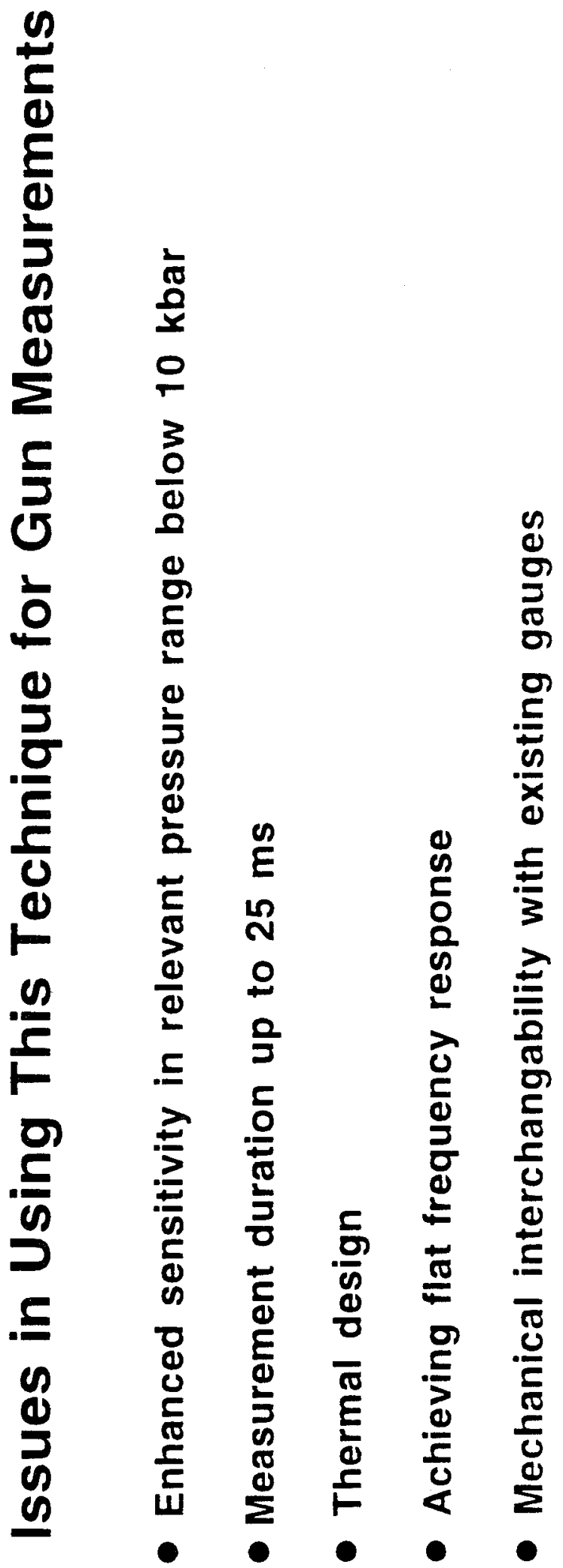


톨

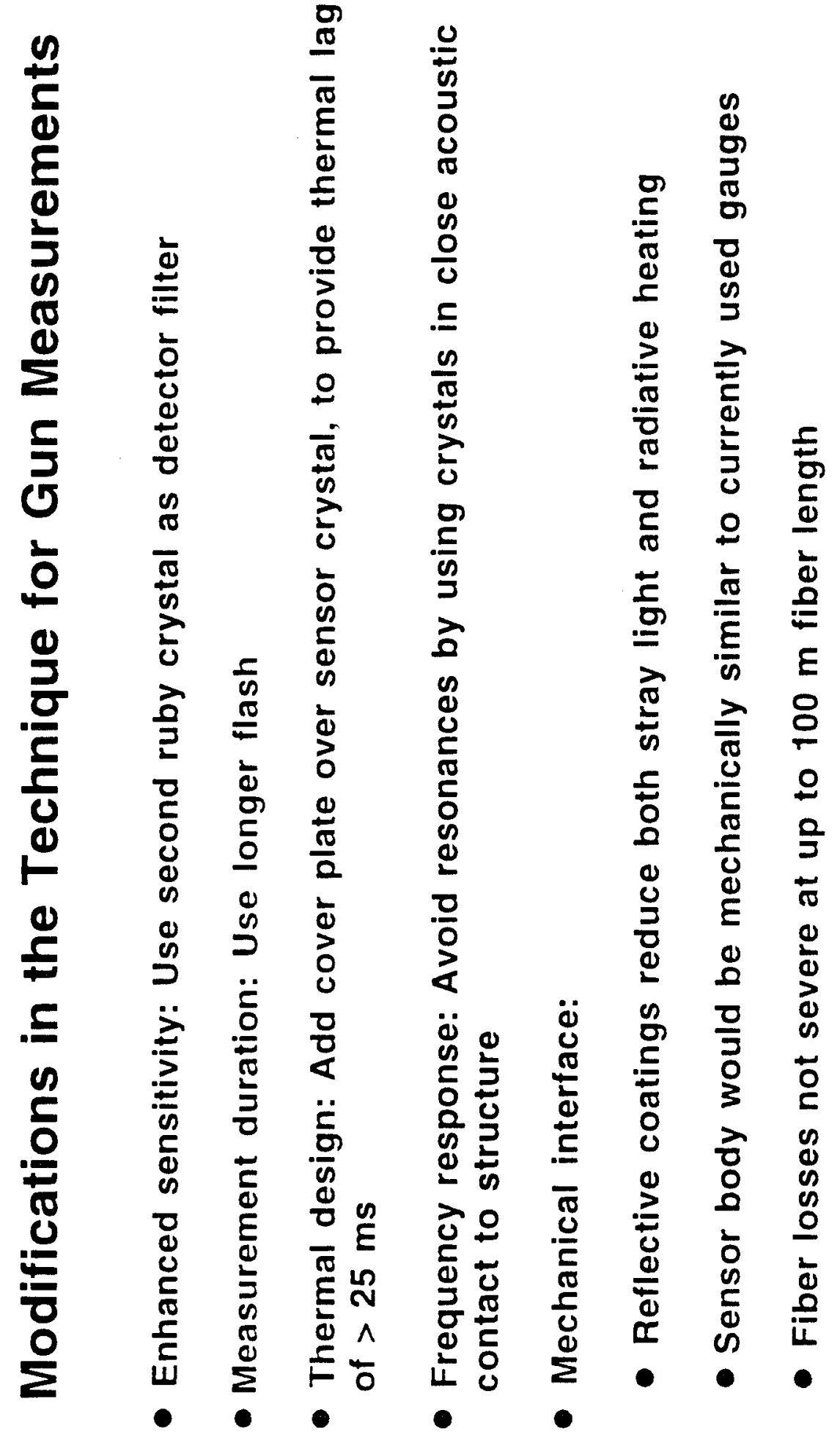



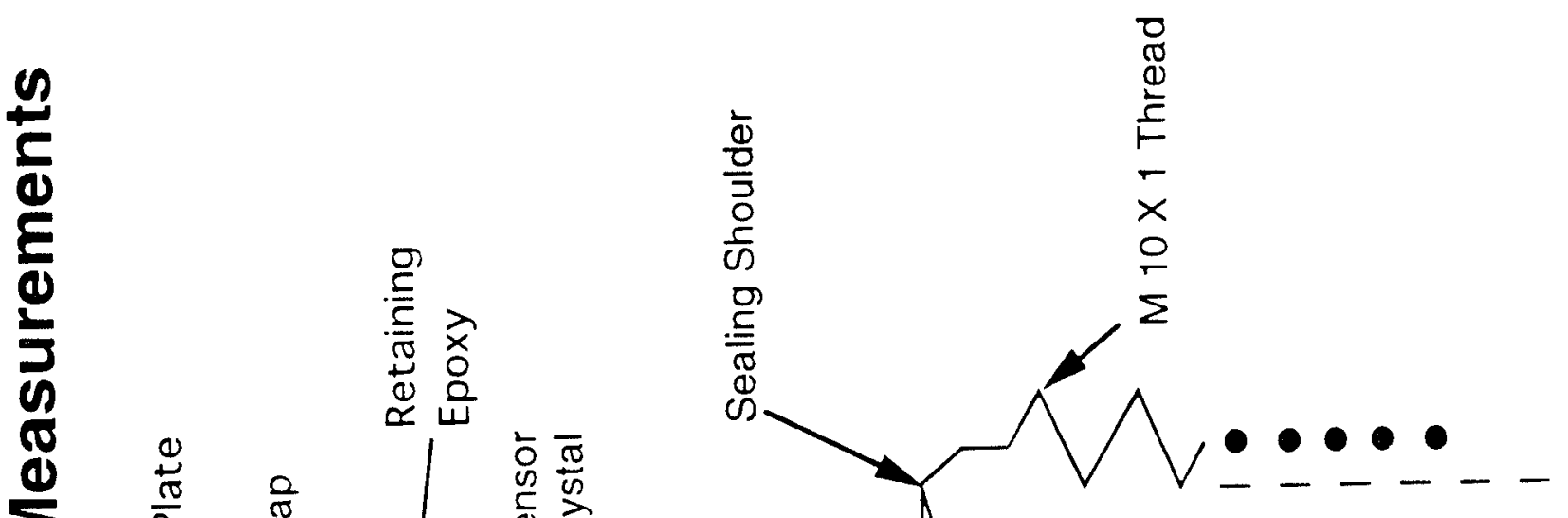

1

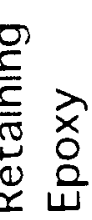

$\frac{0}{2} \quad \frac{\pi}{0}$

员 $\frac{\pi}{\omega}$

5

¿

0

2

(1)

ज

ס

I

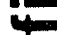

항

을

0

을

I

(1)

$\frac{5}{0}$

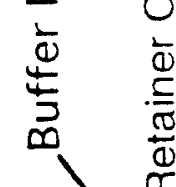
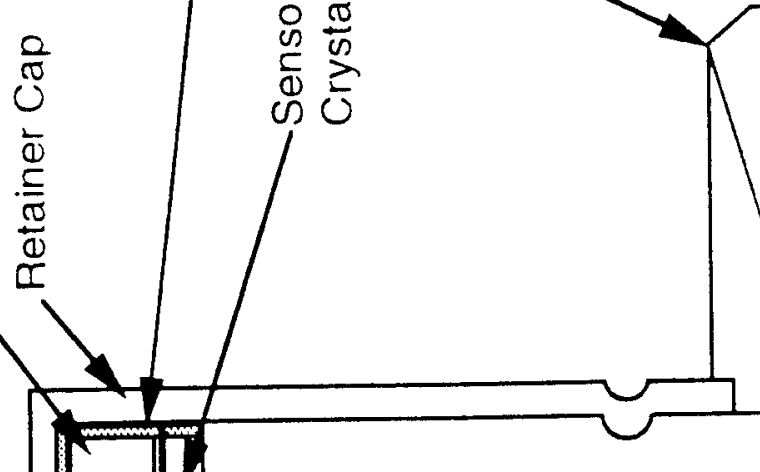

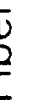
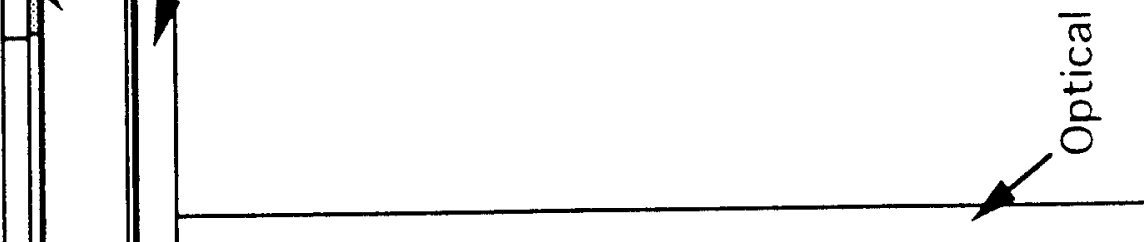

ס

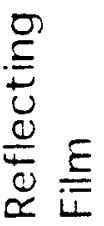
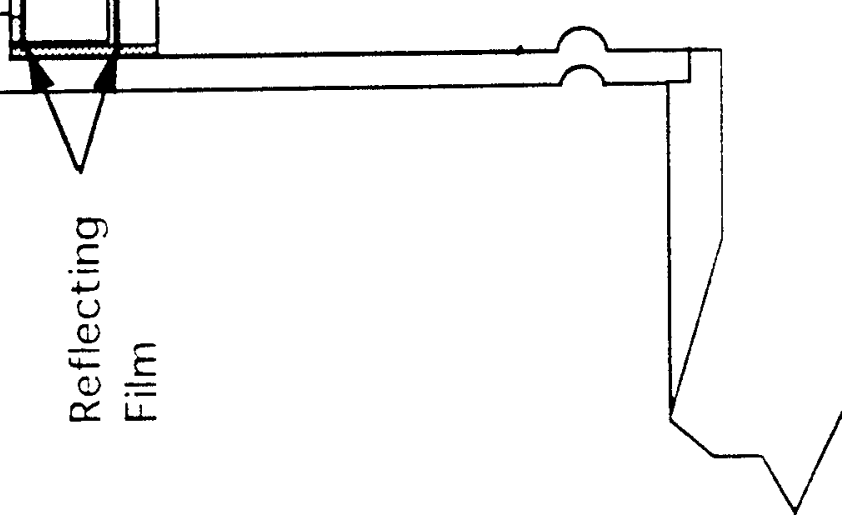


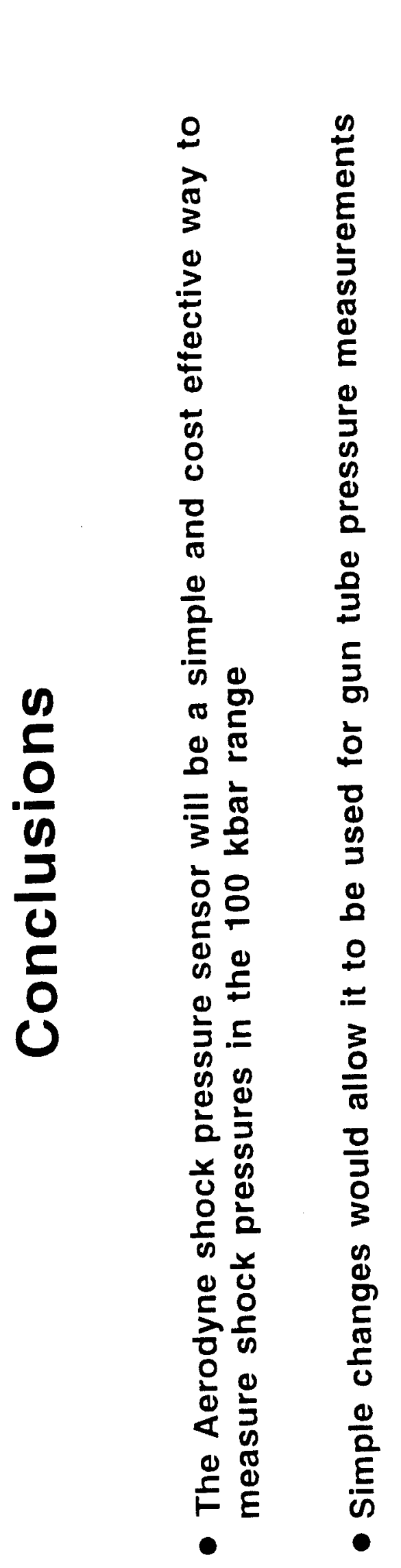

$\frac{\text { 므 }}{\underline{\text { 드 }}}$ 


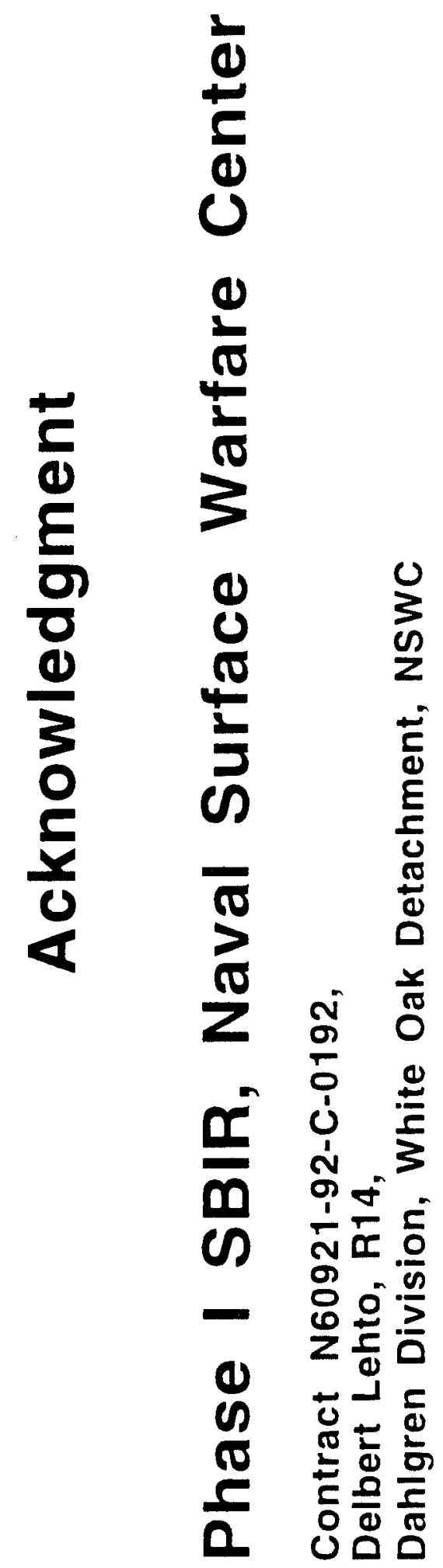


INTENTIONALLY LEFT BLANK. 
APPENDIX G:

PRESENTATION - "PRESSURE TRANSDUCERS FOR THE LIQUID PROPELLANT GUN"

This Appendix is presented in its original form without editorial changes or comments. 
INTENTIONALLY LEFT BLANK. 


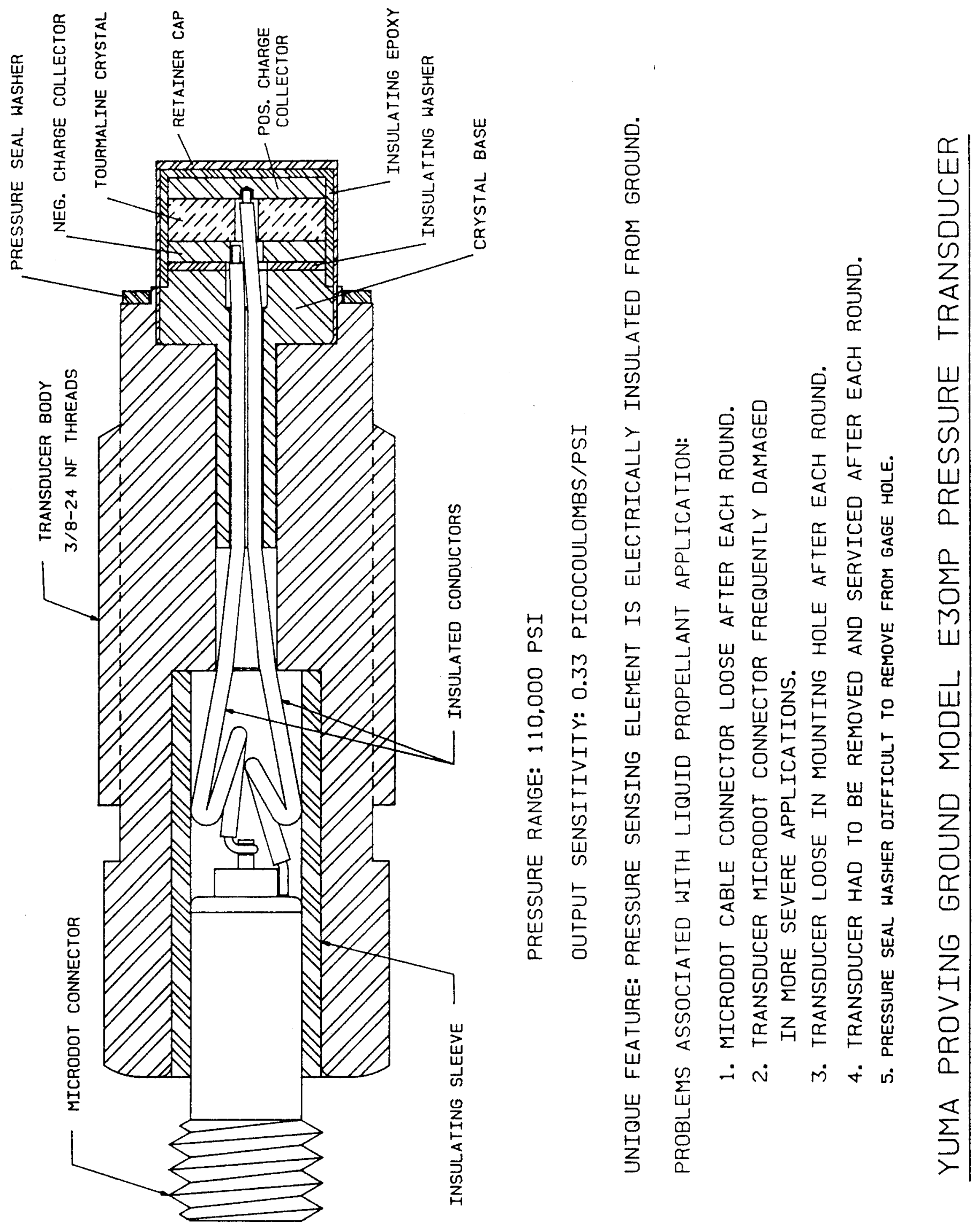




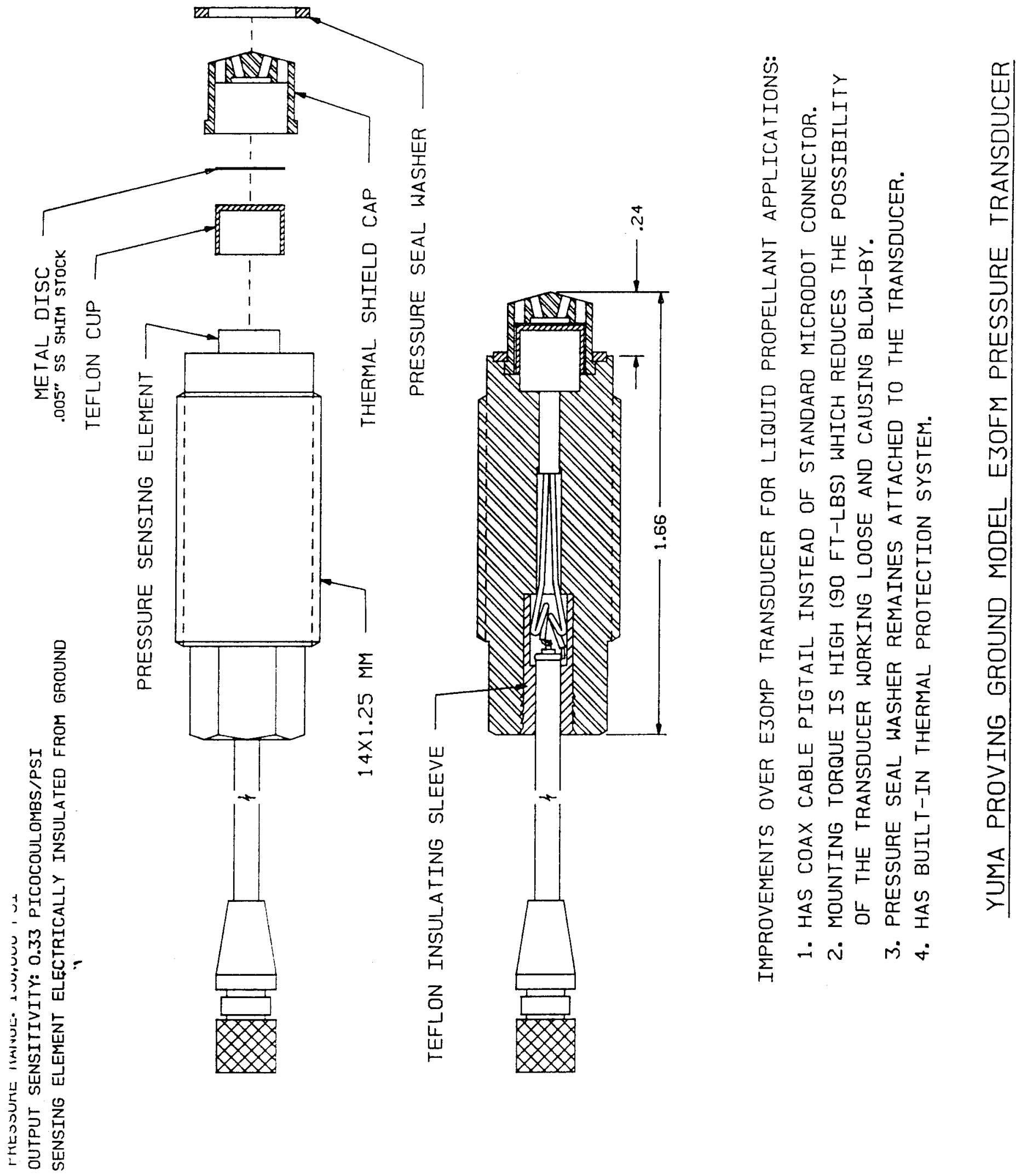




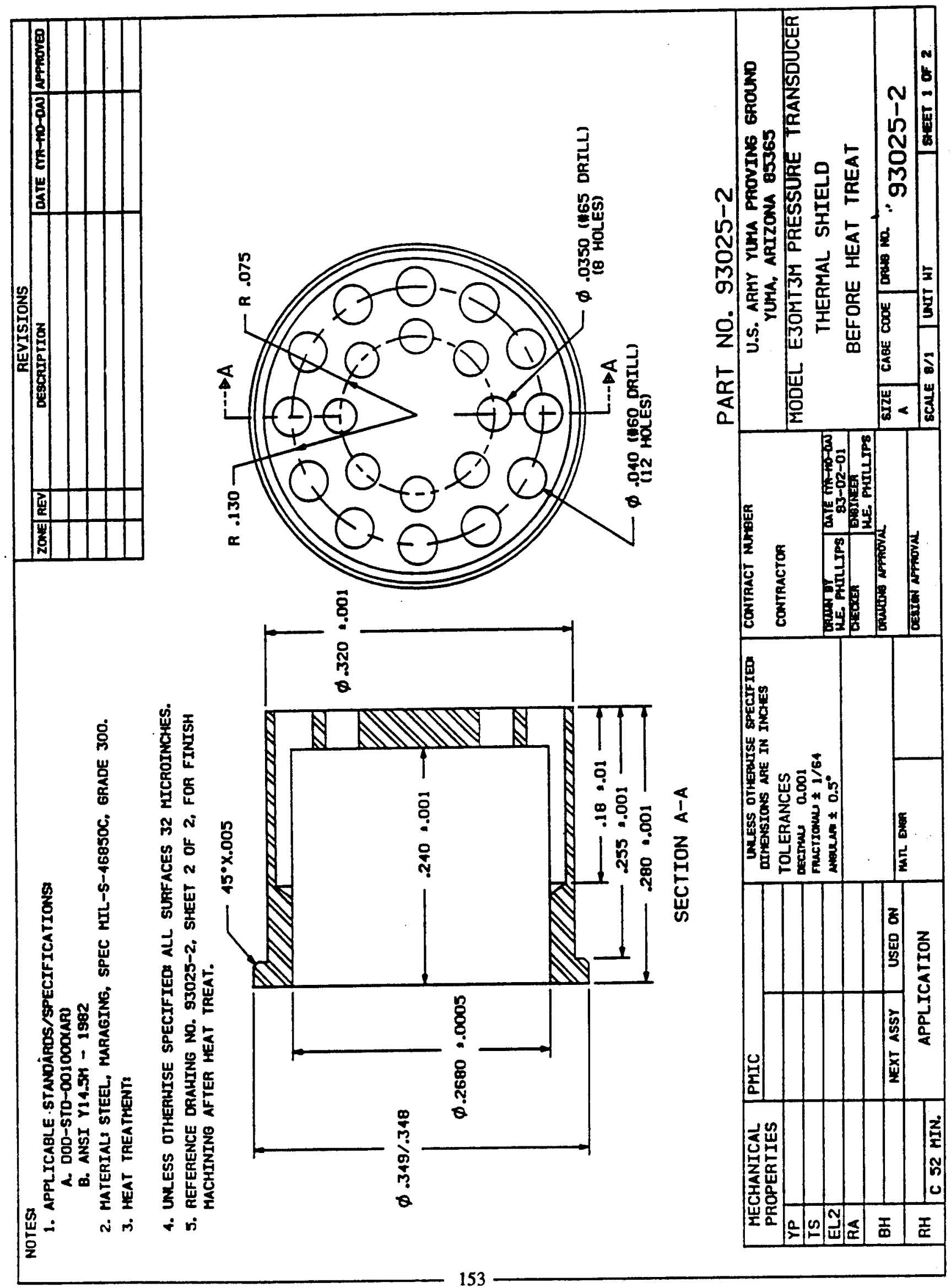




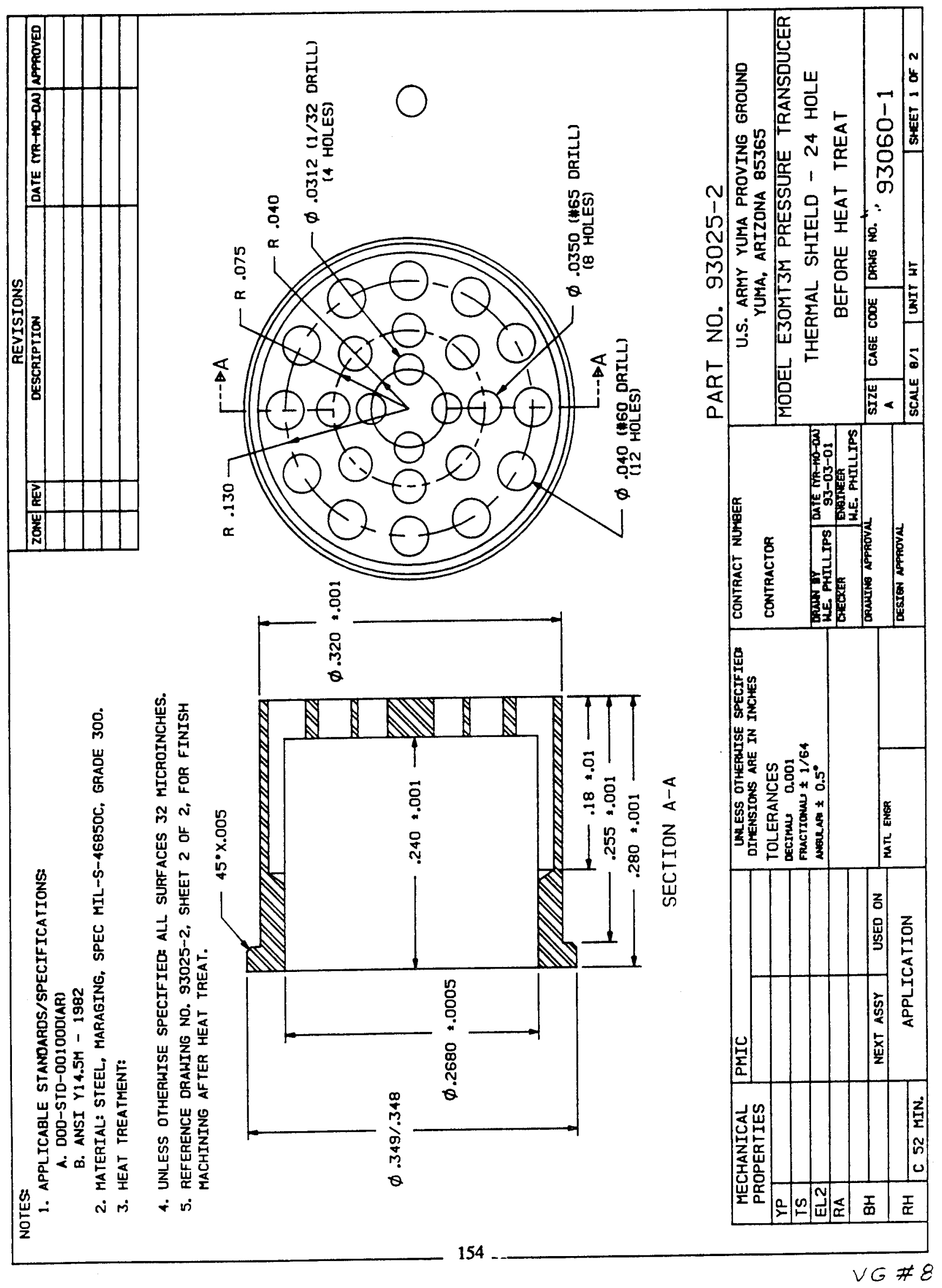




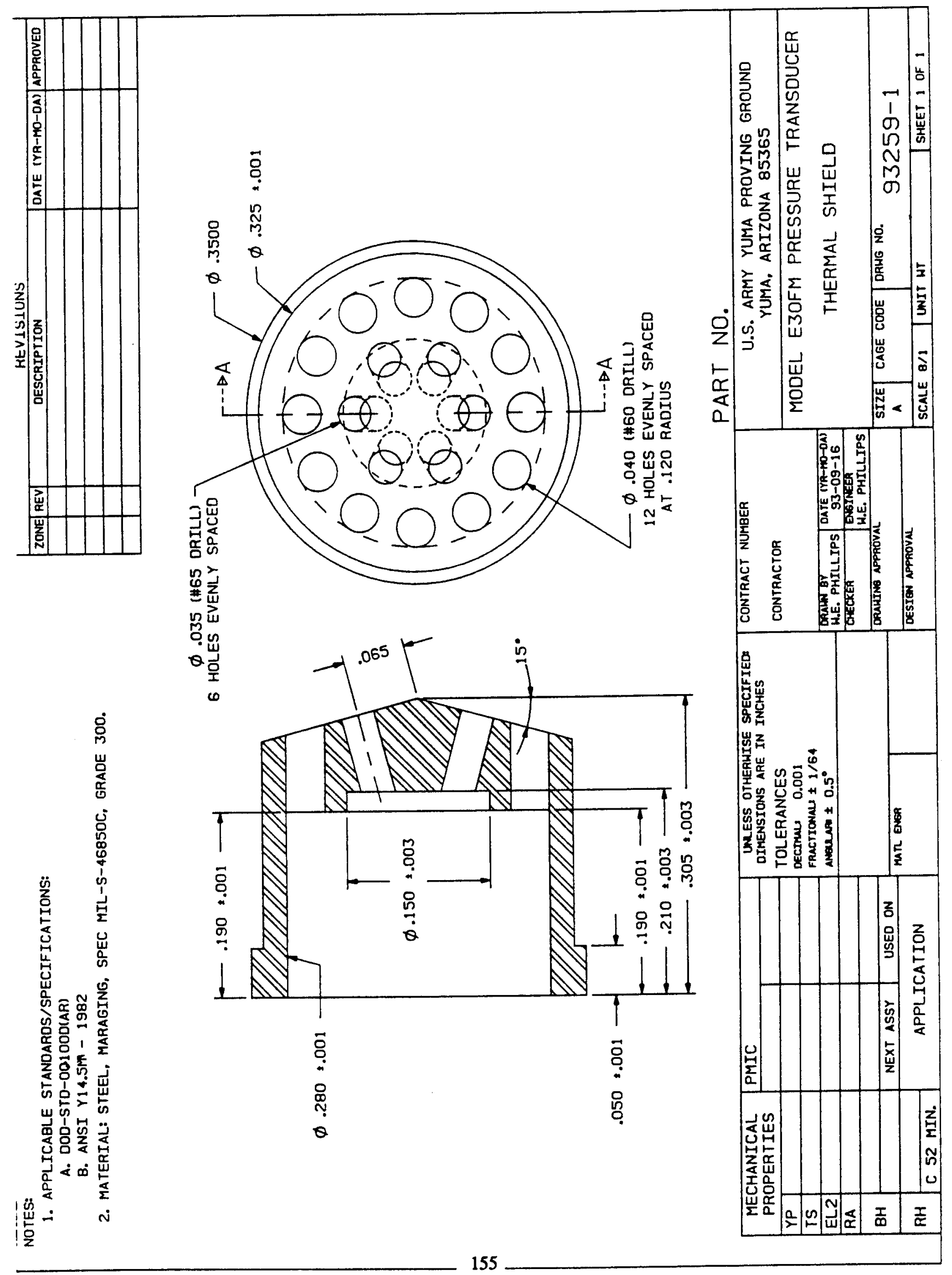




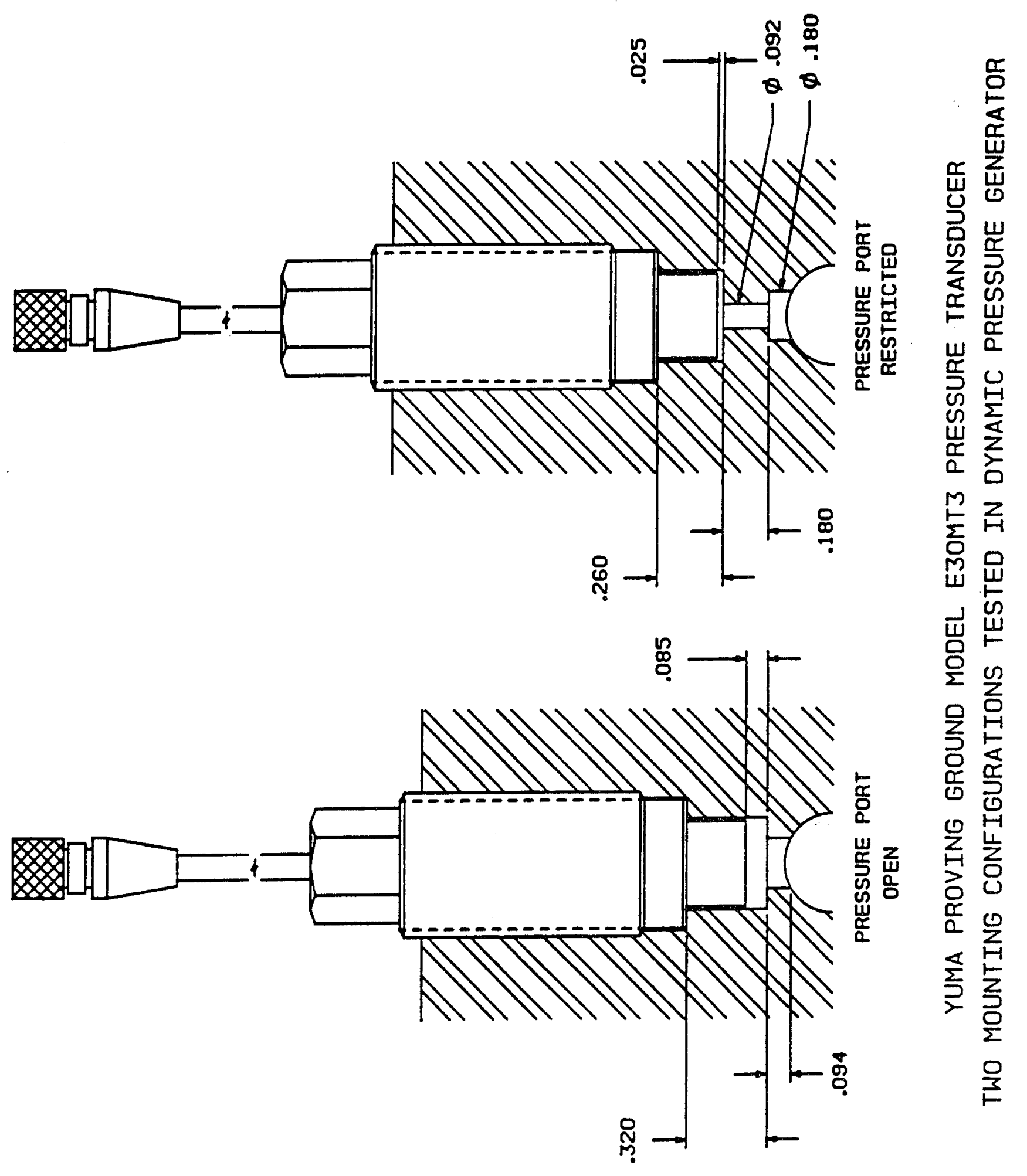




\section{PRESSURE TRANSDUCER \\ CALIBRATION REPORT \\ MOUNTING SENSITIVITY TEST}

YPG MODEL E3OMT3 SERIAL NO. 27

PRESSURE

PSIG

(1)

(2)

OUTPUT

PICOCOULOMBS

(3)
AVERAGE MAX. OUTPUT DEV.

$\%$

(4)

$\begin{array}{lllllll}30000 & 9169 & 9195 & 9209 & 9241 & 9204 & 0.40\end{array}$

$\begin{array}{lllllll}40000 & 12220 & 12270 & 12290 & 12380 & 12290 & 0.73\end{array}$

$\begin{array}{lllllll}50000 & 15270 & 15320 & 15330 & 15490 & 15350 & 0.90\end{array}$

$\begin{array}{lllllll}60000 & 18320 & 18390 & 18440 & 18580 & 18430 & 0.81\end{array}$

$\begin{array}{lllllll}70000 & 21380 & 21440 & 21470 & 21490 & 21440 & 0.23\end{array}$

(1) FULL THERMAL PROTECTION-24 HOLE THERMAL CAP-OPEN PRESSURE PORT

(2) FULL THERMAL PROTECTION-24 HOLE THERMAL CAP-RESTRICTED PRESSURE PORT

(3): THERMAL CAP ONLY-RESTRICTED PRESSURE PORT

(4) FULL THERMAL PROTECTION-24 HOLE THERMAL CAP-RESTRICTED PRESSURE PORTPRESSURE PORT FILLED WITH GREASE (PENZOIL 705) 


\section{PRESSURE TRANSDUCER \\ CALIBRATION REPORT \\ MOUNTING SENSITIVITY TEST}

YPG MODEL E3OMT3 SERIAL NO. 25

\begin{tabular}{|c|c|c|c|c|c|}
\hline $\begin{array}{l}\text { PRESSURE } \\
\text { PSIG }\end{array}$ & & $\begin{array}{l}\text { DUTPUT } \\
\text { OCOULON }\end{array}$ & & $\begin{array}{l}\text { ÁVERAGE } \\
\text { OUTPUT }\end{array}$ & $\begin{array}{l}\text { MAX. } \\
\text { DEV. }\end{array}$ \\
\hline & (1) & (2) & (3) & & $\%$ \\
\hline 30000 & 9480 & 9490 & 9490 & 9487 & 0.07 \\
\hline 40000 & 12670 & 12680 & 12680 & 12680 & \\
\hline 50000 & 15810 & 15840 & 15830 & 15830 & \\
\hline 60000 & 18950 & 19000 & 19020 & 18990 & \\
\hline 70000 & 22080 & 22140 & 22150 & 22120 & \\
\hline
\end{tabular}

(1) FULL THERMAL PROTECTION-20 HOLE THERMAL CAP-RESTRICTED PRESSURE PORT

(2) FULL THERMAL PROTECTION-20 HOLE THERMAL CAP-OPEN PRESSURE PORT

(3) :FULL THERMAL PROTECTION-24 HOLE THERMAL CAP-OPEN PRESSURE PORT 


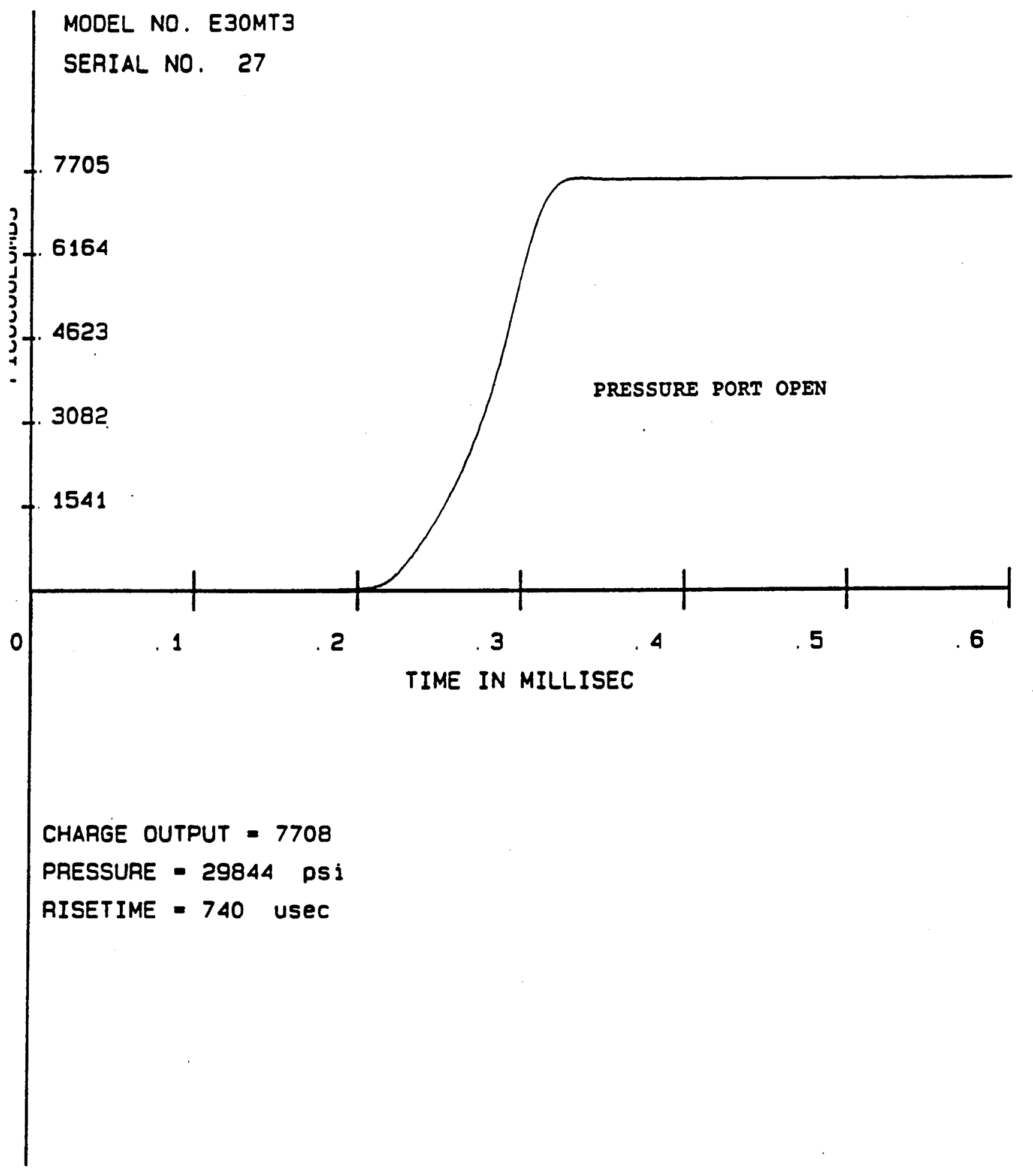




$$
02-19-93
$$

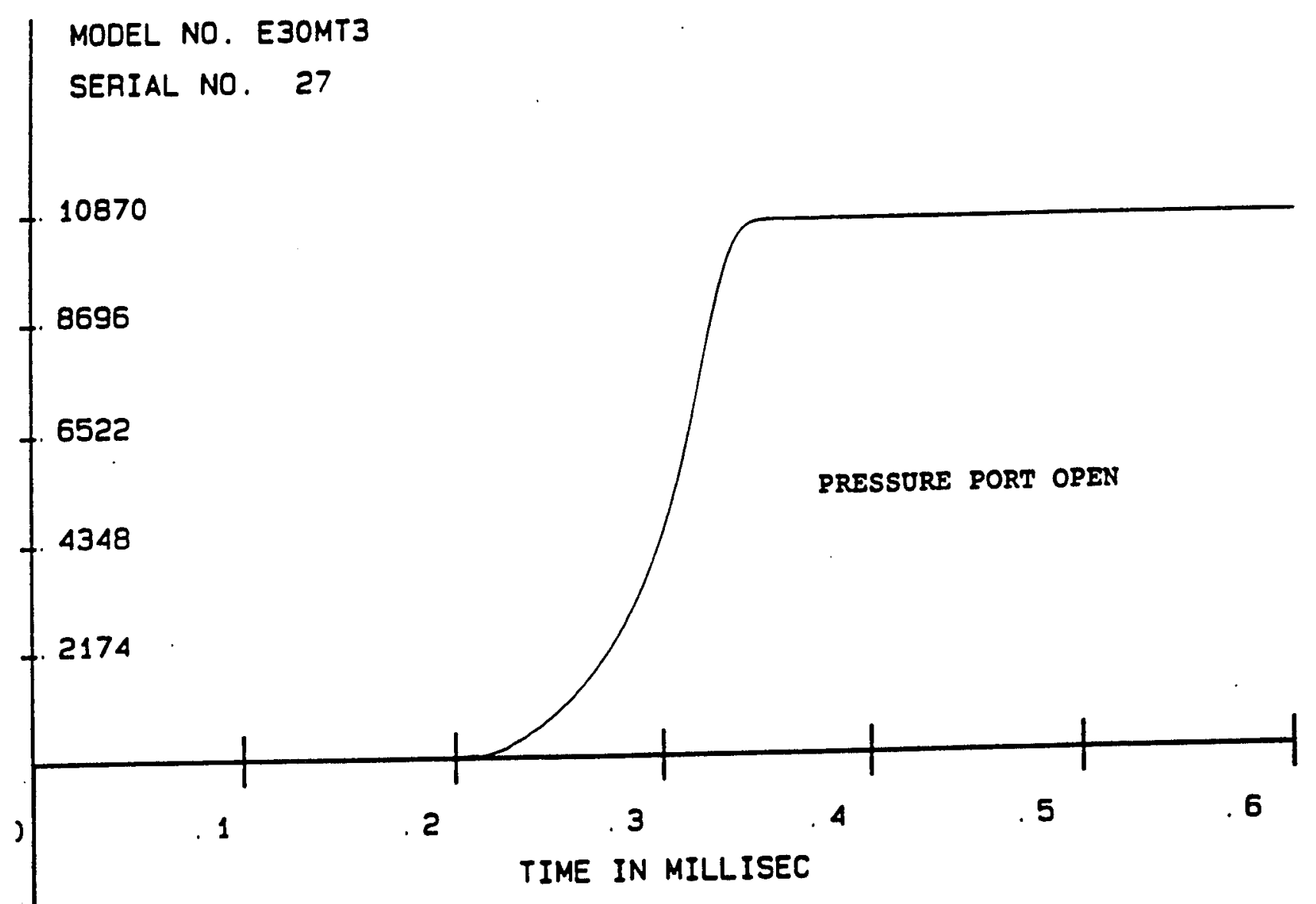

CHARGE OUTPUT $=10871$

PRESSURE = 69692 DS 1

RISETIME $=760$ usec 


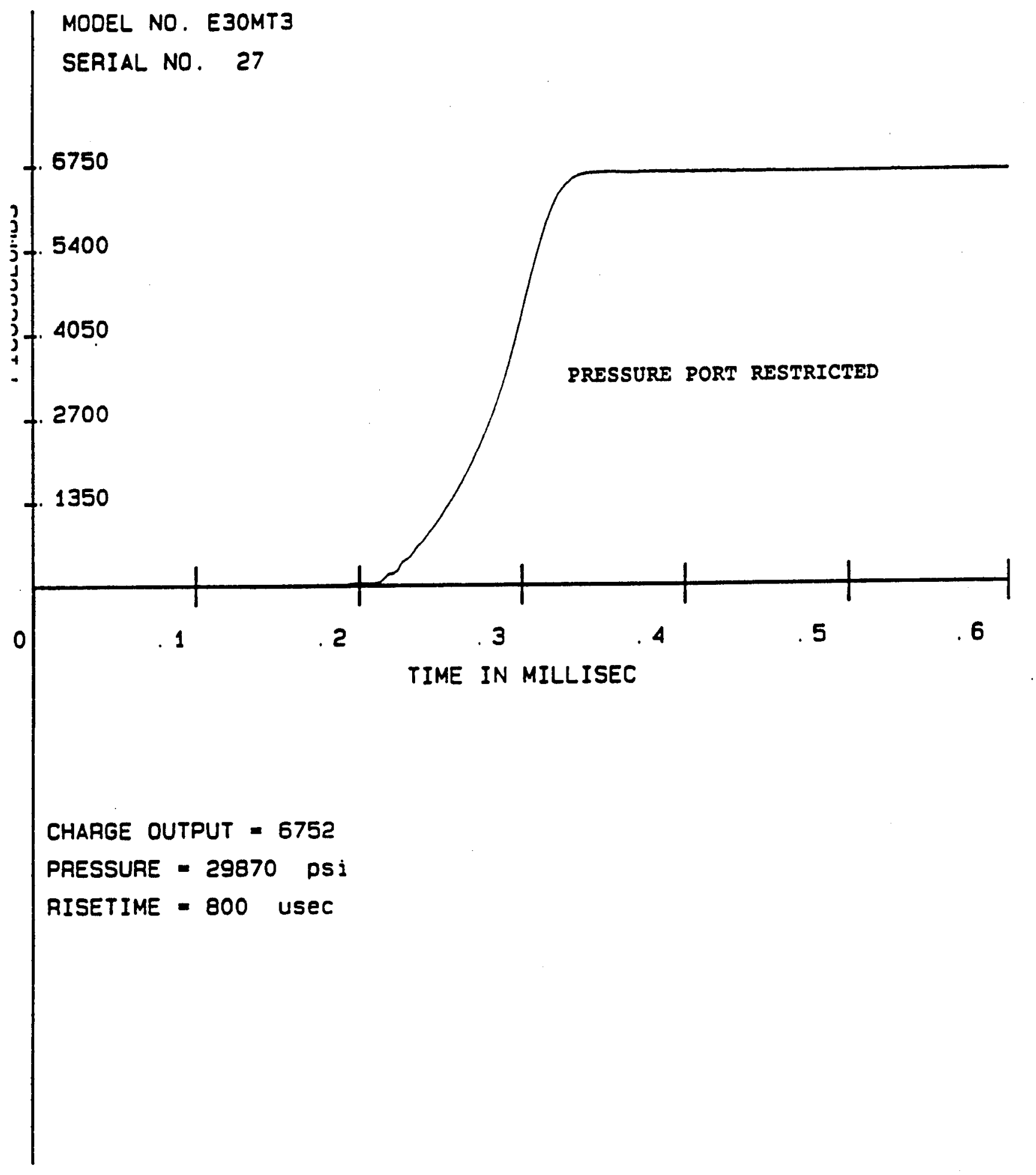


YPG BALLISTIC TRANSDUCEA LAB

$$
02-19-93
$$

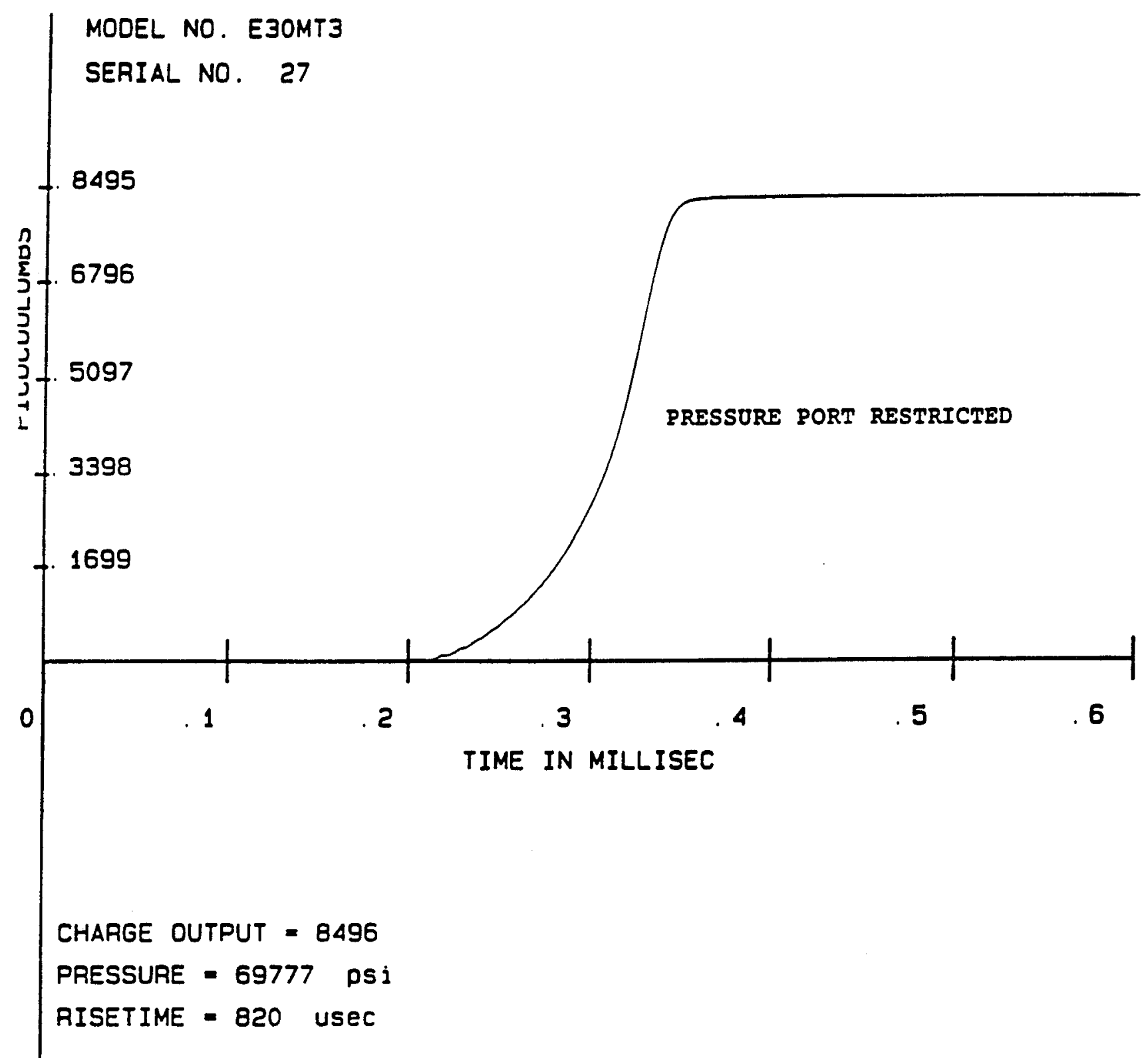


YPG BALLISTIC TRANSDUCER LAB

$$
02-22-93
$$

MODEL NO. E3OMT3

SERIAL NO. 27

$$
30,000 \text { PSI }
$$

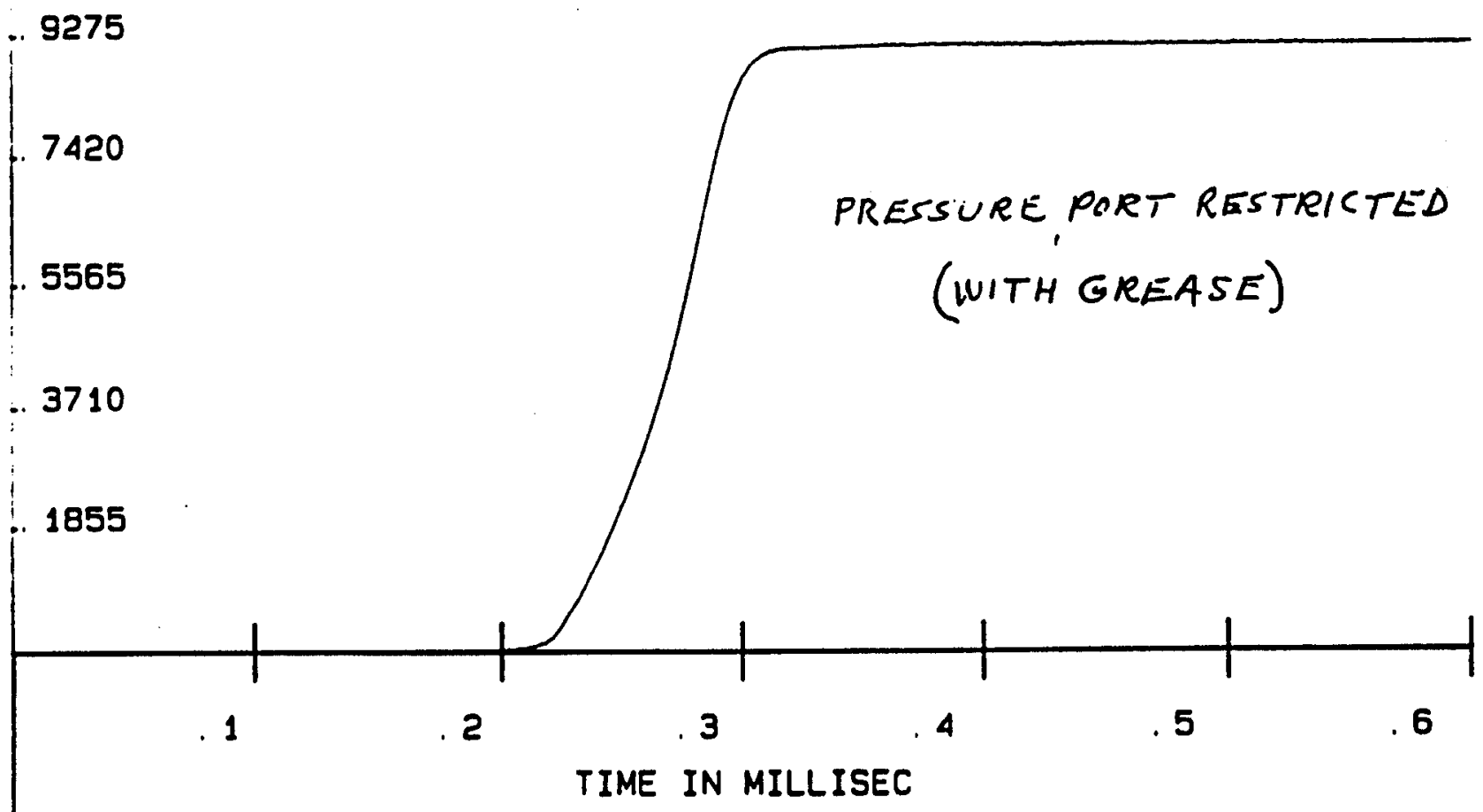

RISETIME $=630$ usec 
YPG BALLISTIC TRANSDUCER LAB

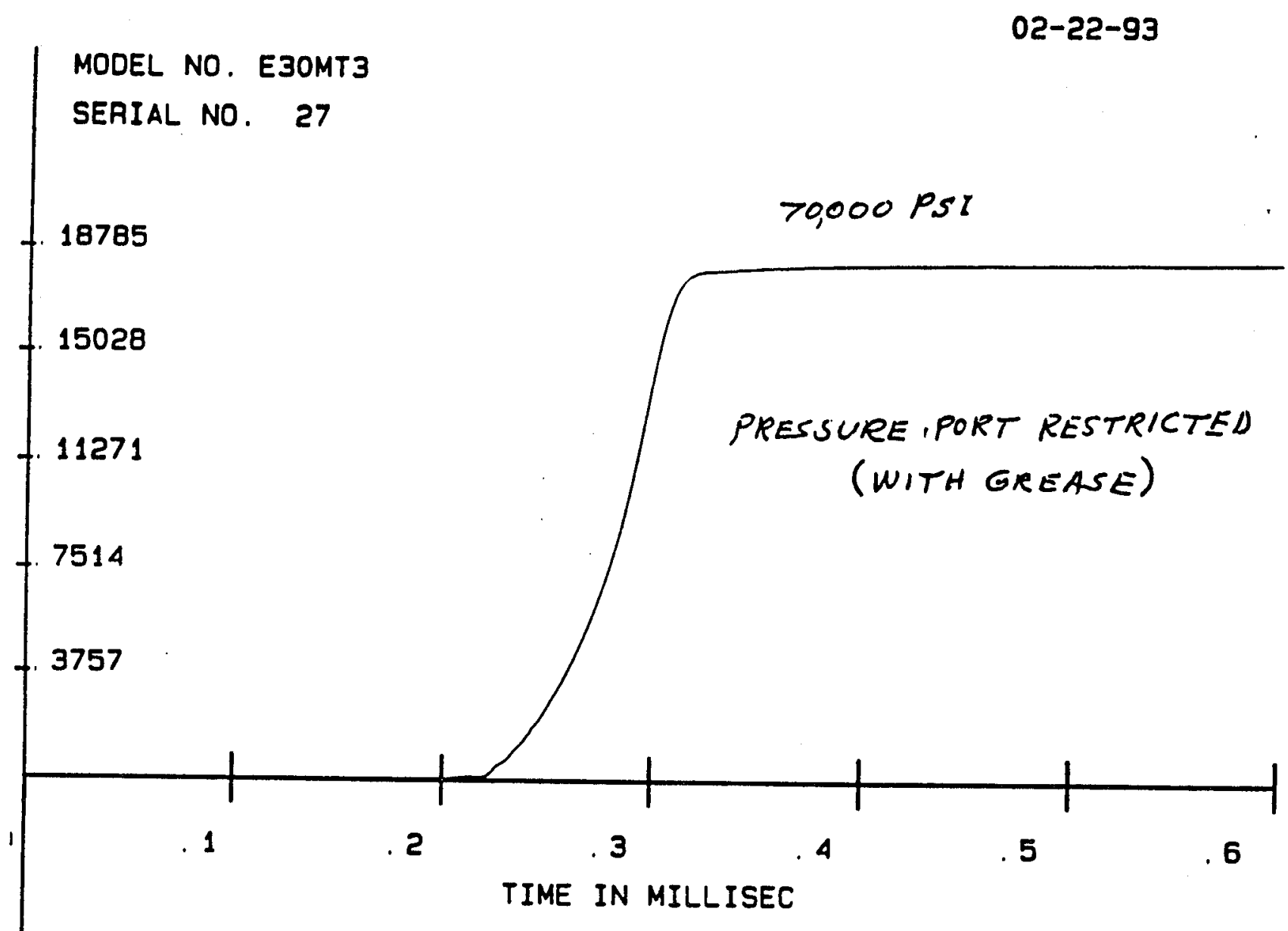

RISETIME $=640$ usec 
APPENDIX H:

PRESENTATION - "FIBER OPTIC PRESSURE TRANSDUCERS"

This Appendix is presented in its original form without editorial changes or comments. 
INTENTIONALLY LEFT BLANK. 

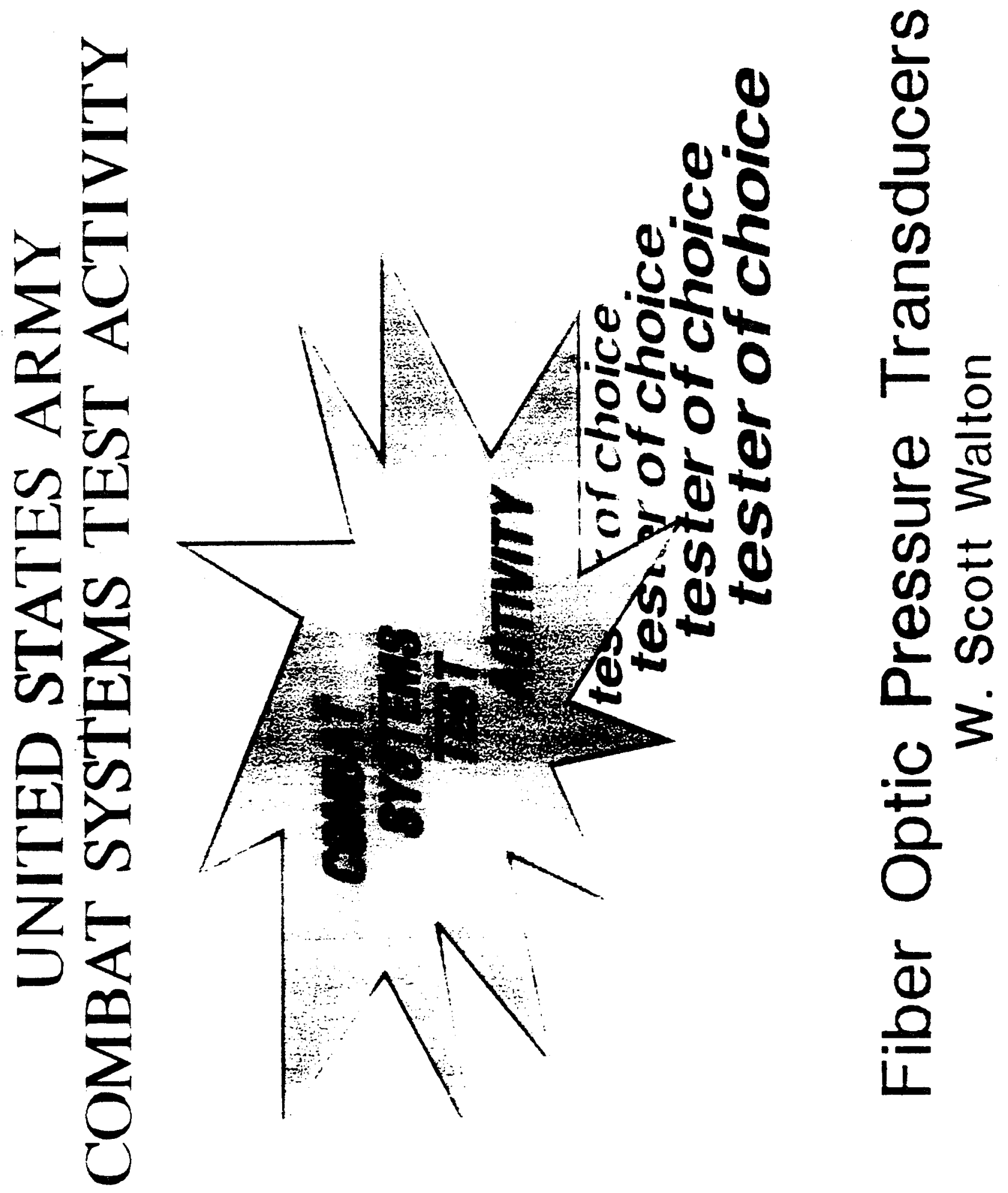


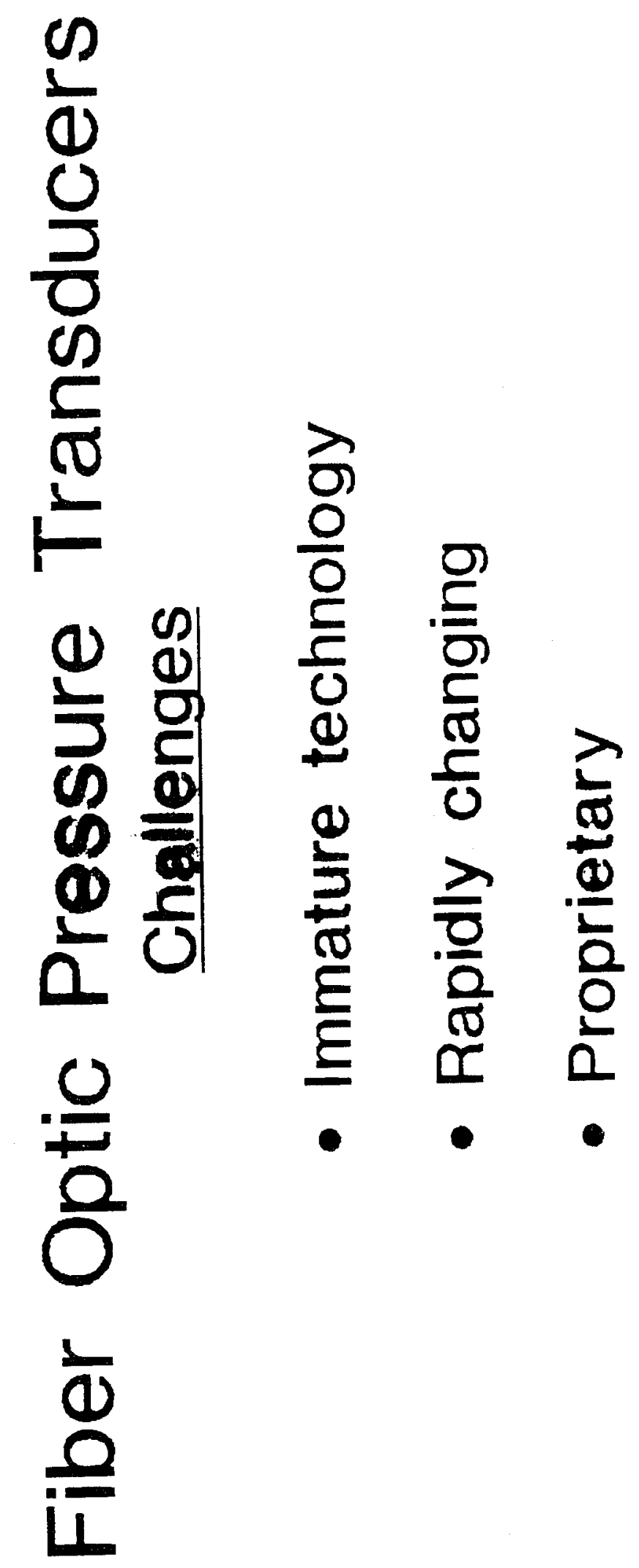




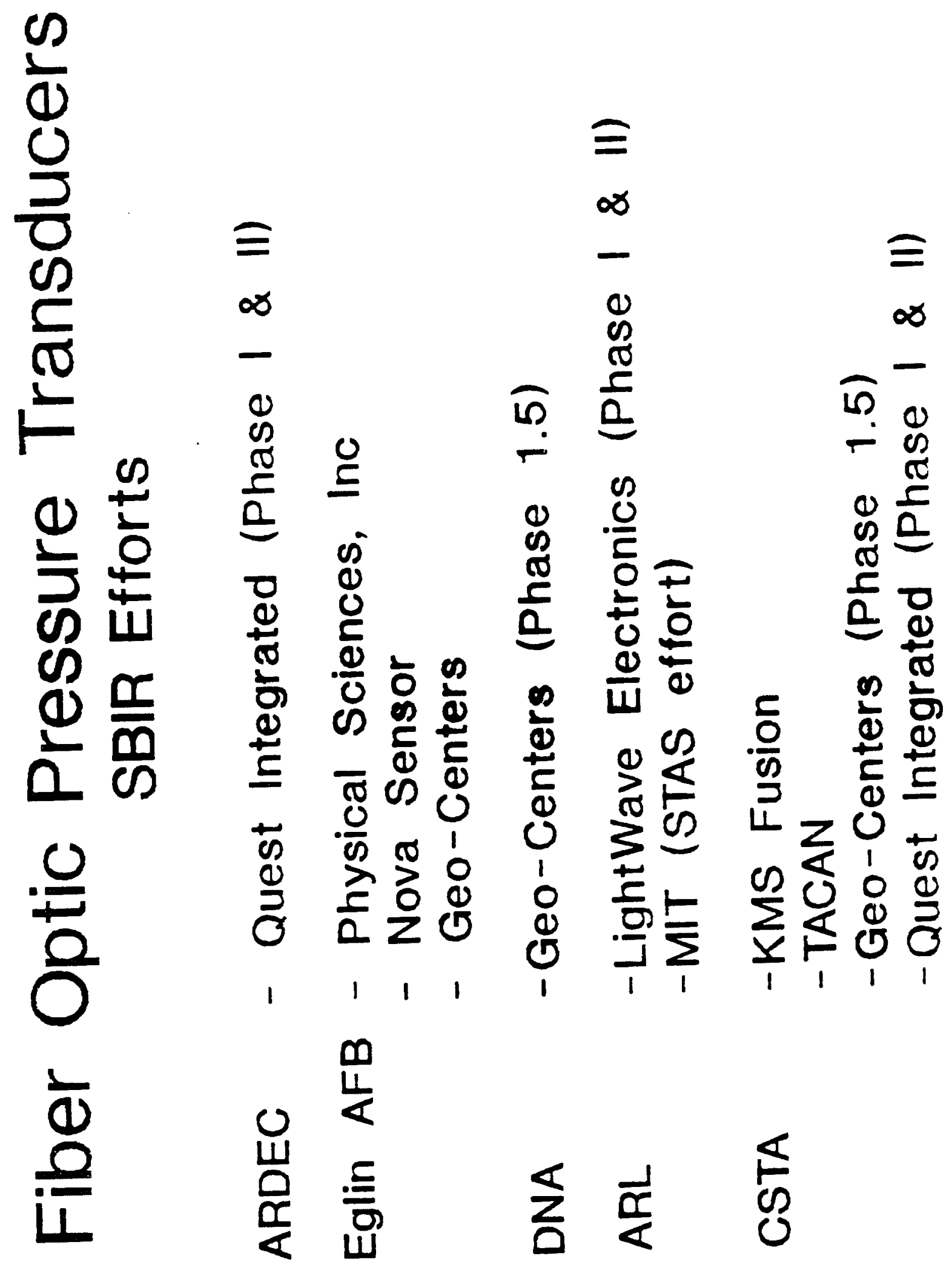




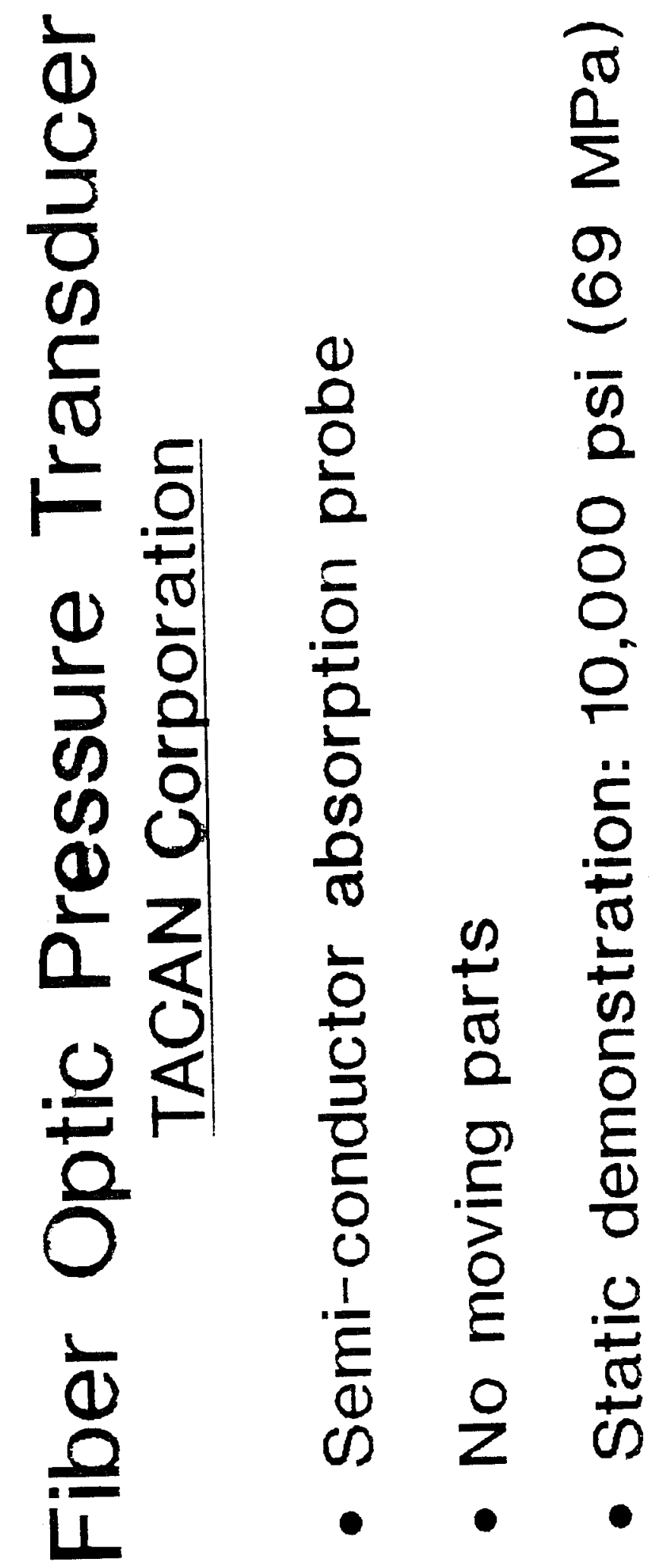




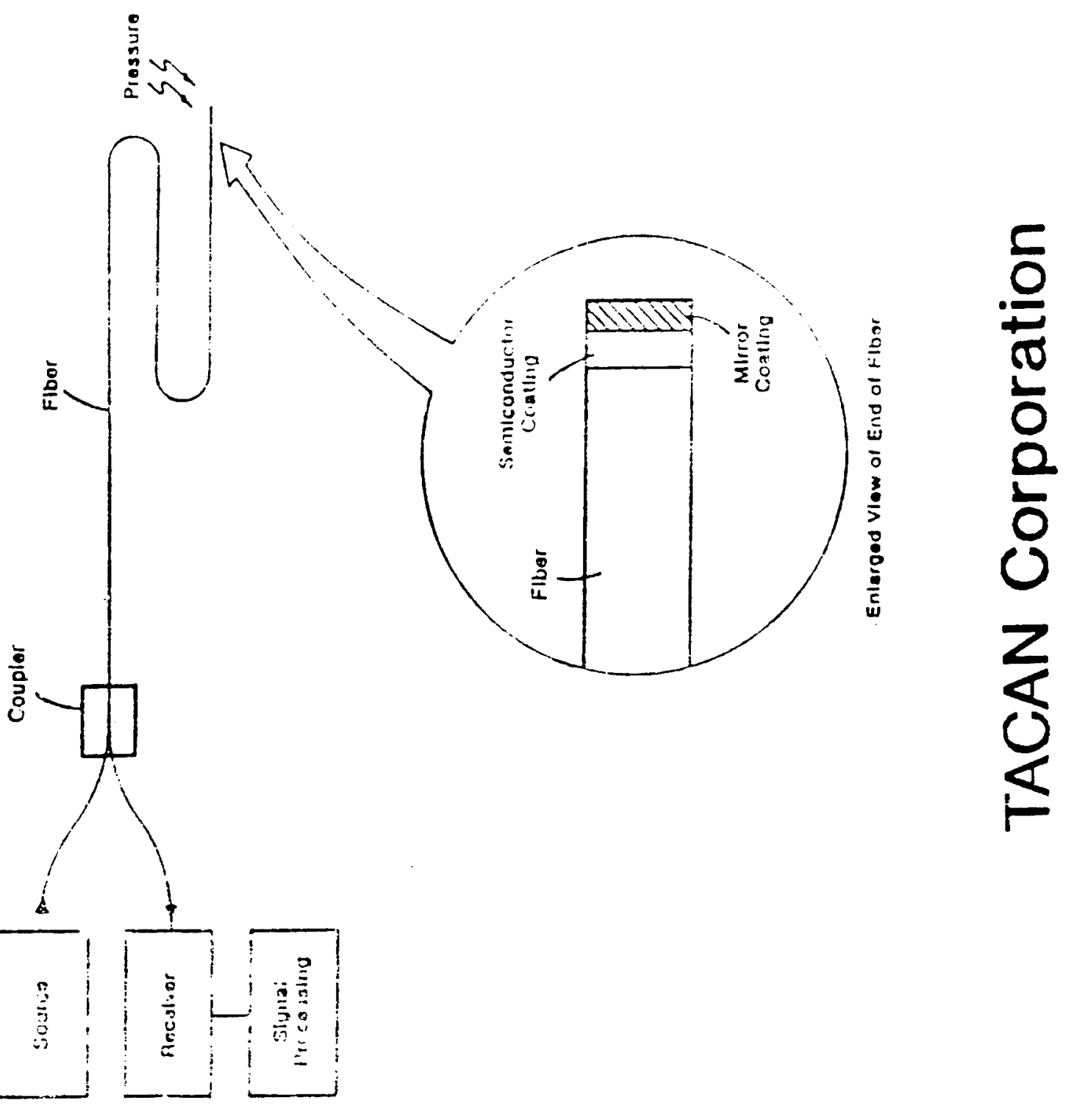




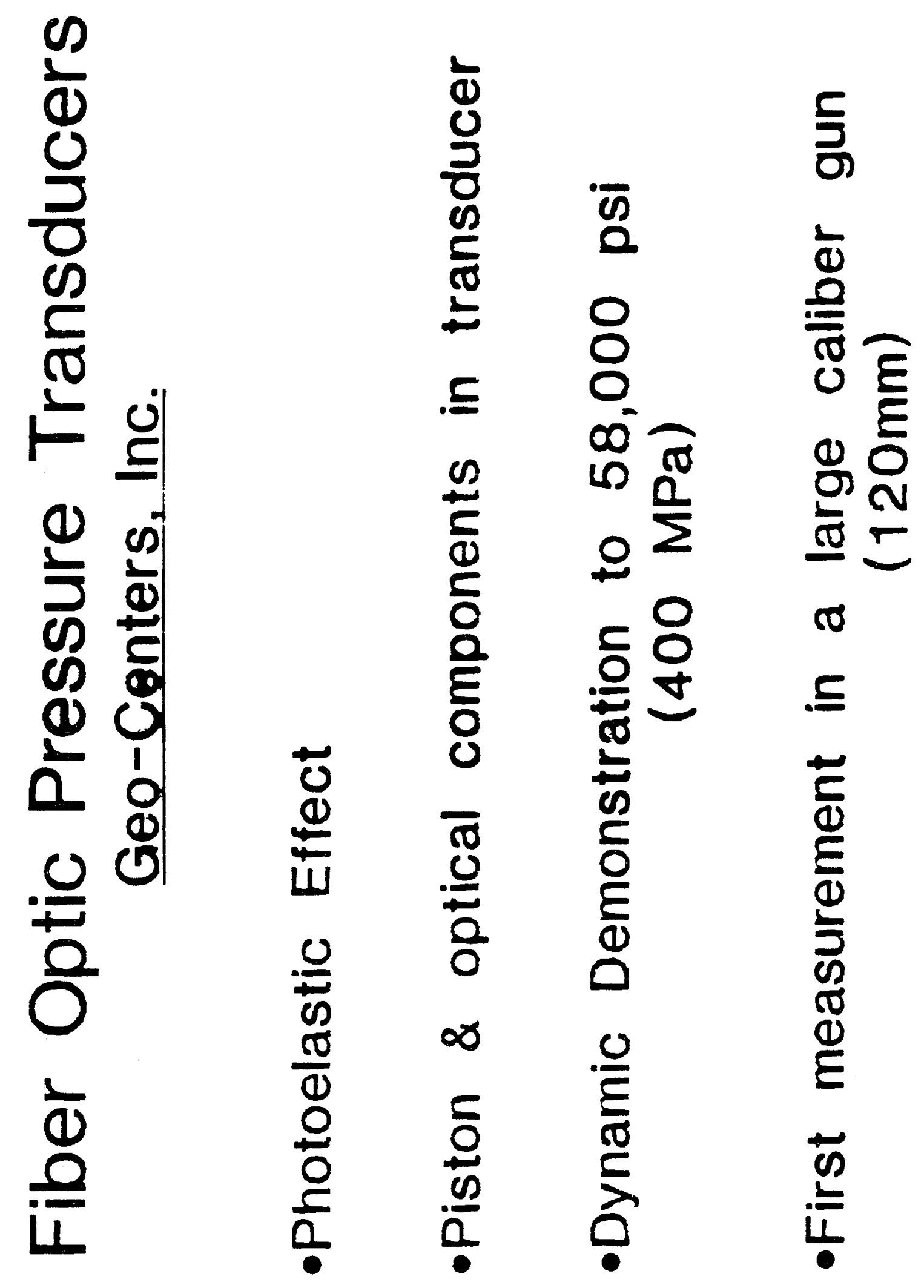




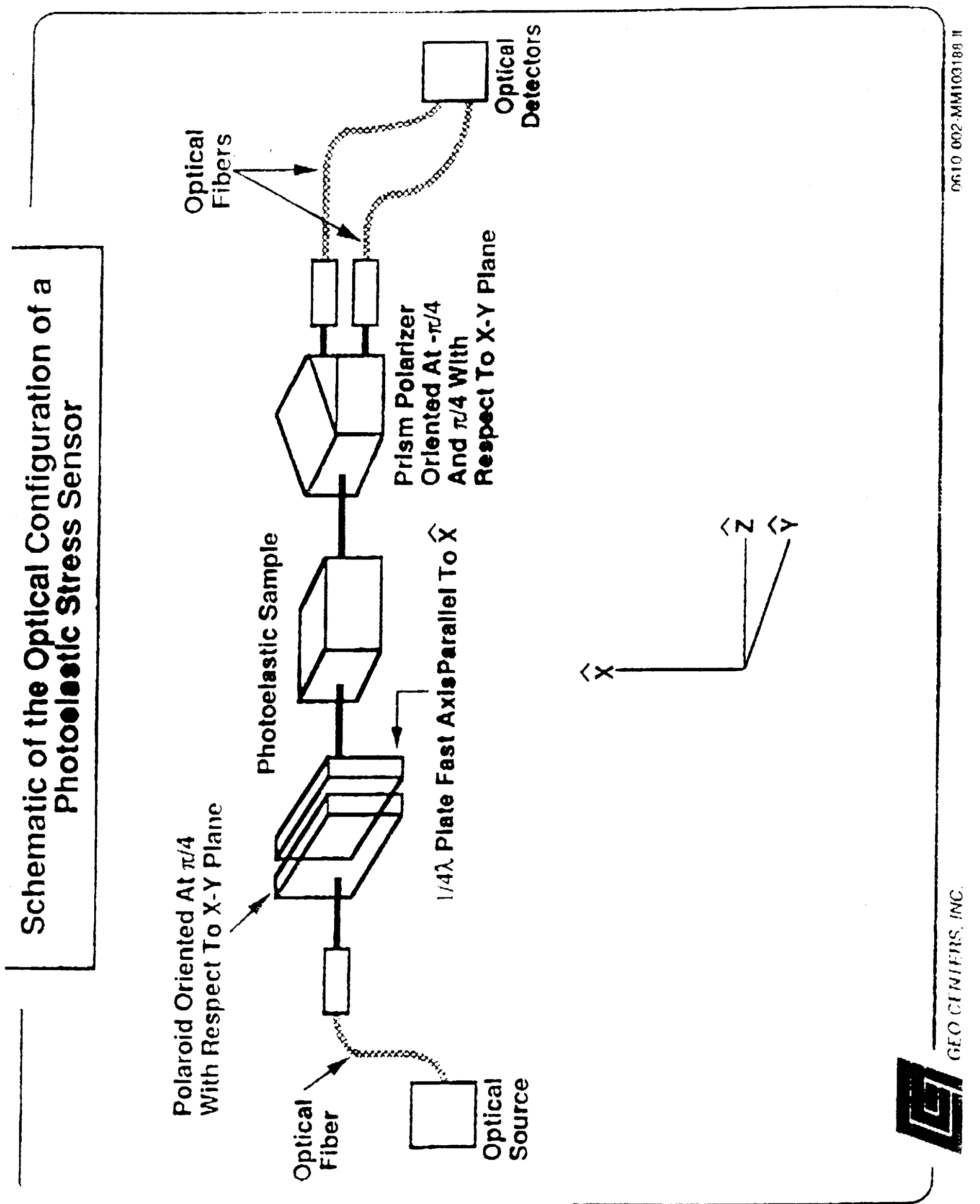




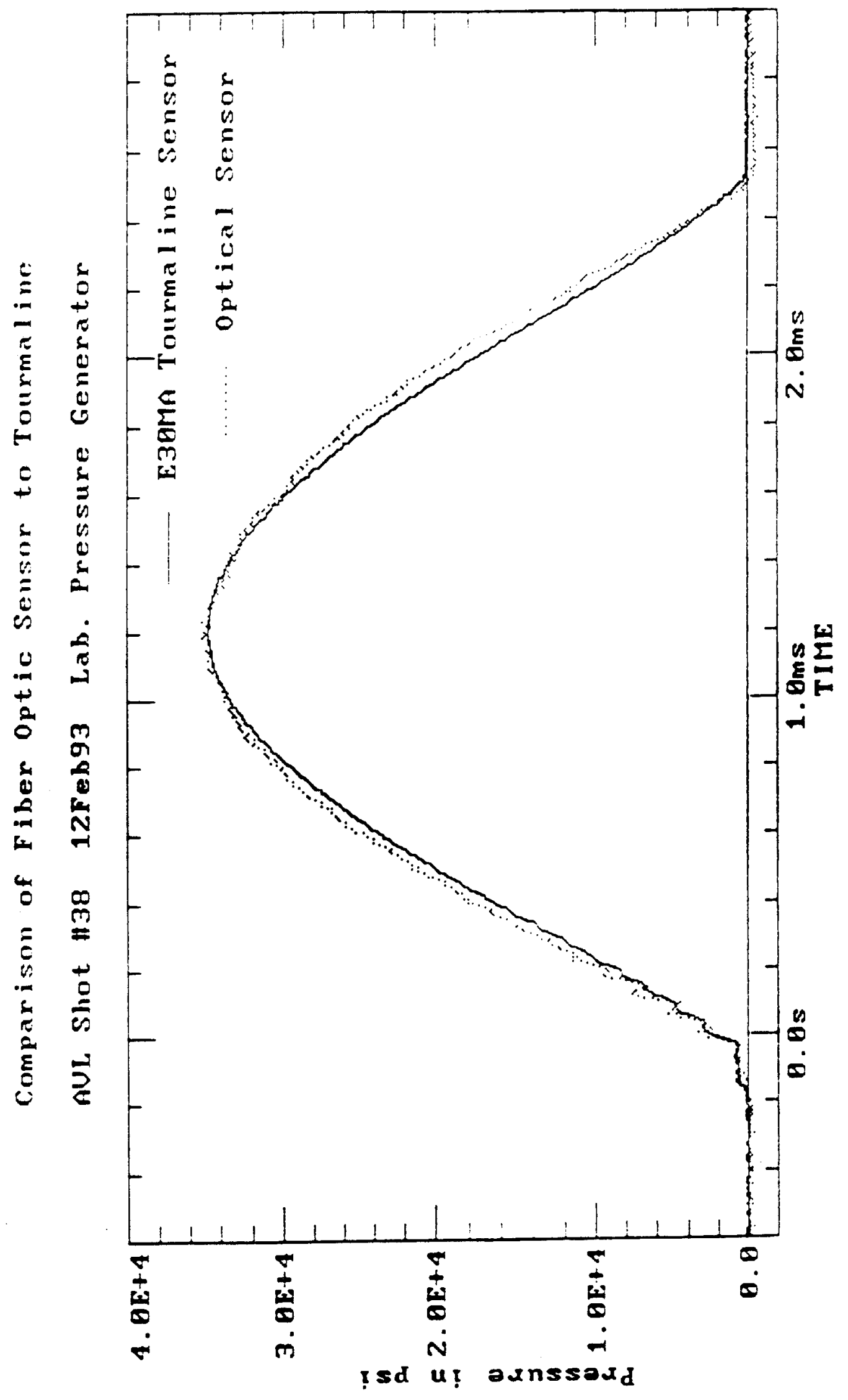

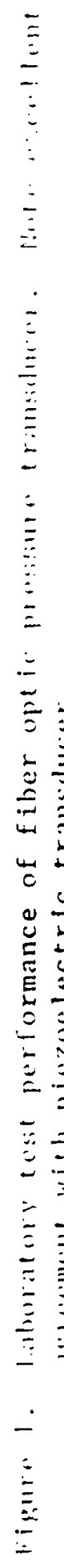




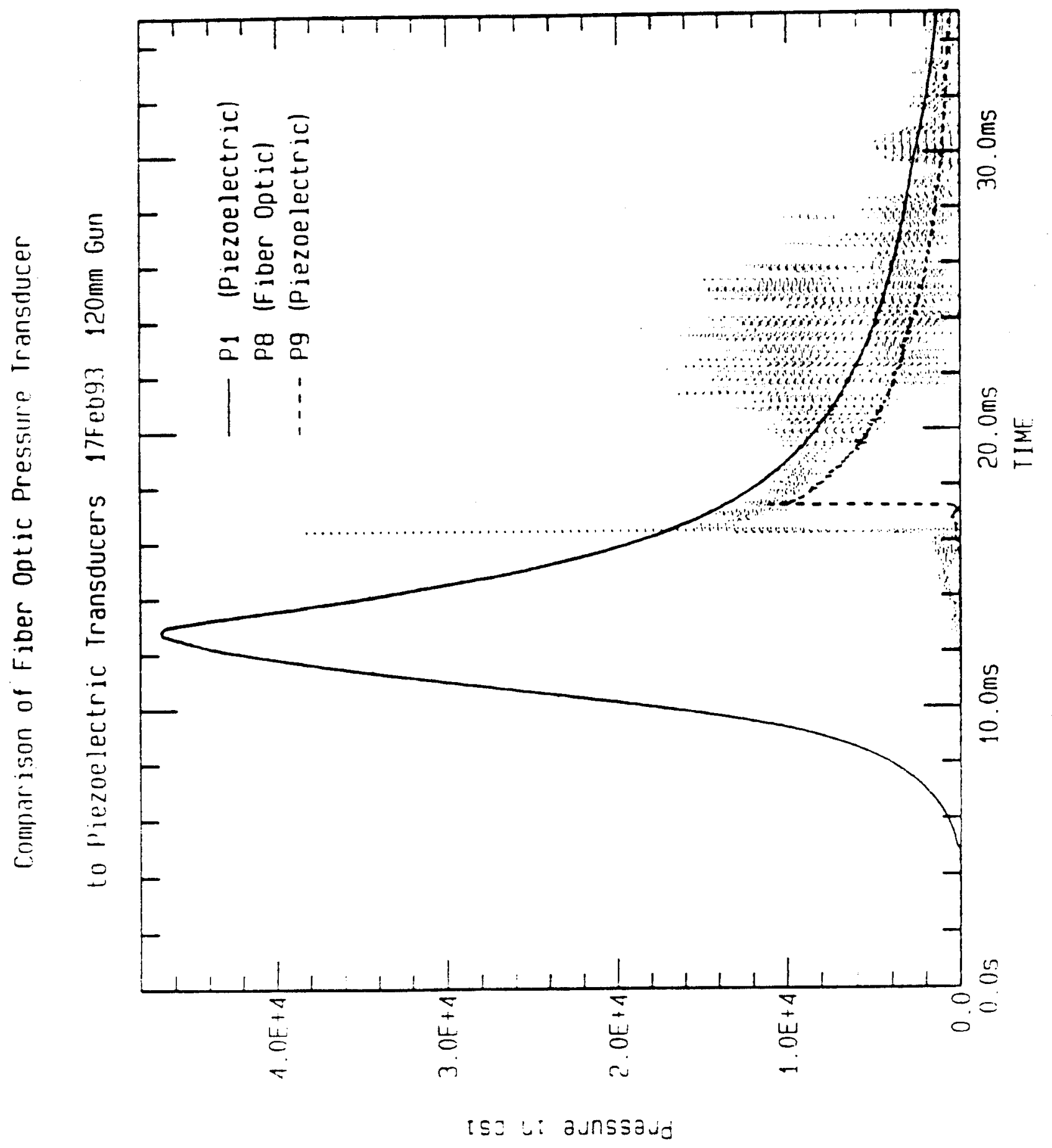

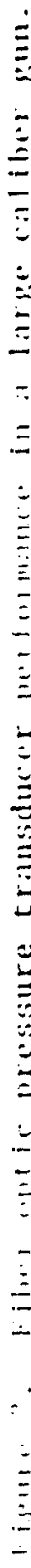




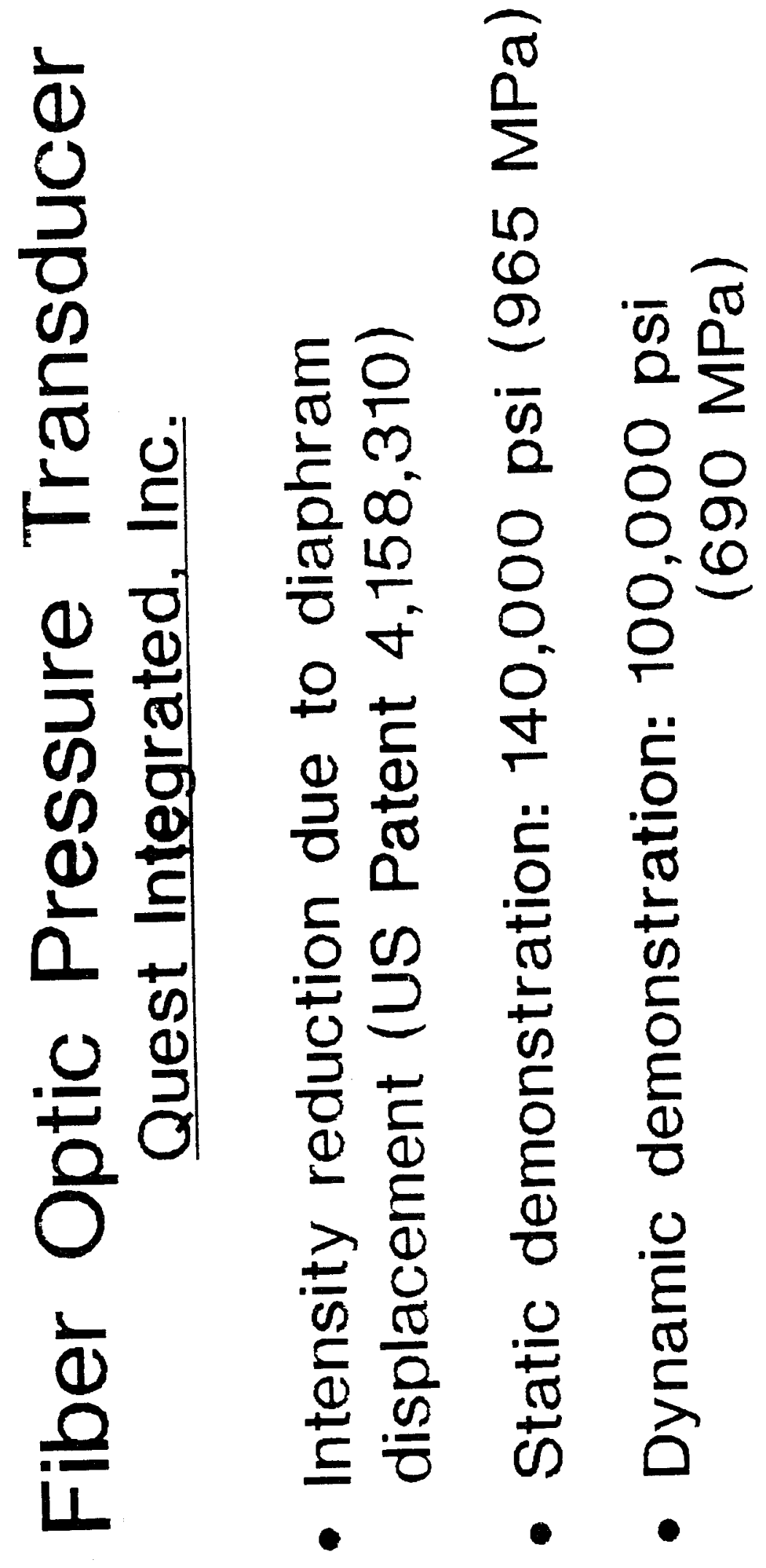




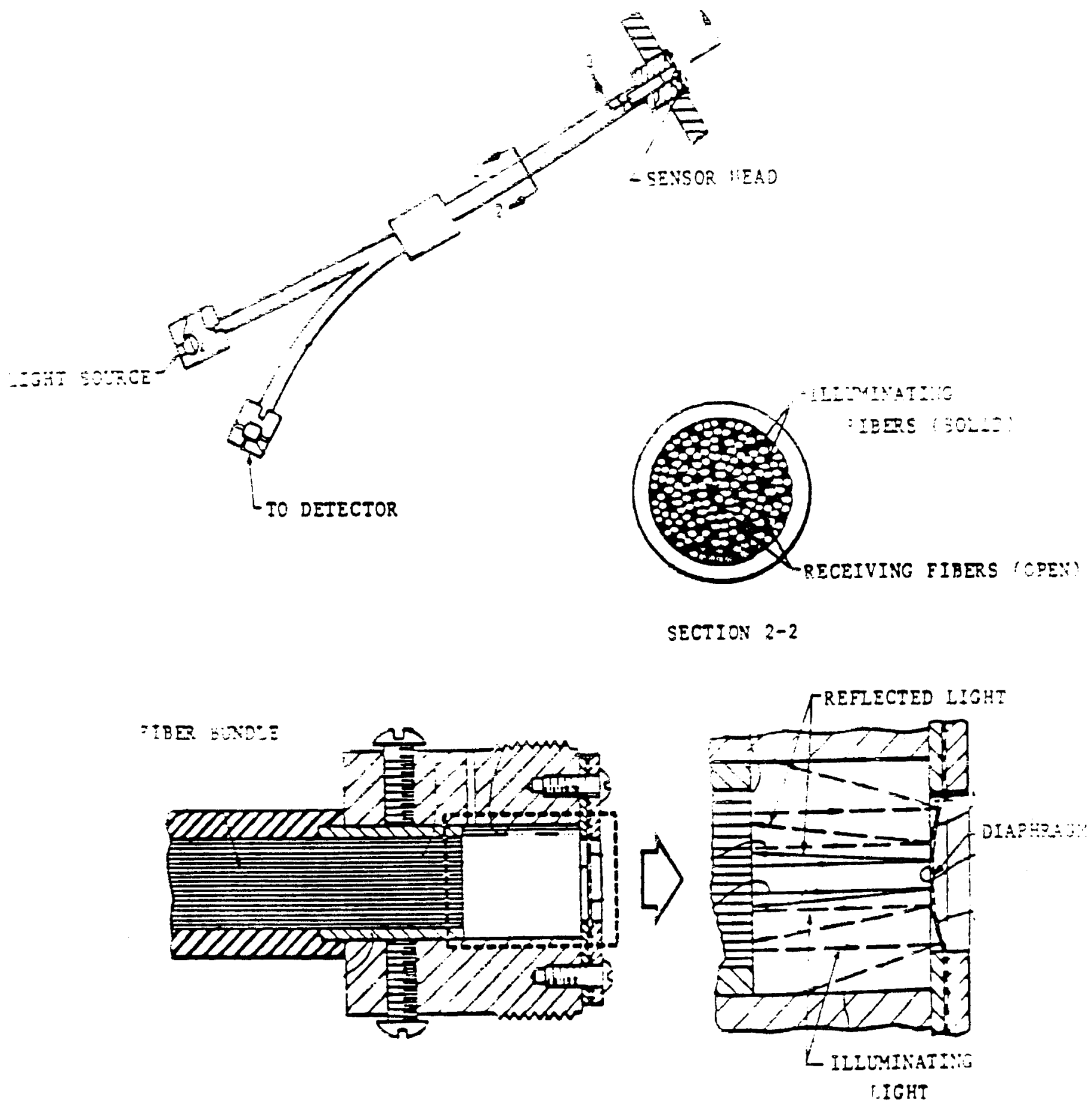

SECTICN $3-3$

Figure 2. Schematic of an FOPT with Randomly Distributed Fiber Bundles (U.S. Patent 4,158,310)

\section{Quest Integrated Inc}




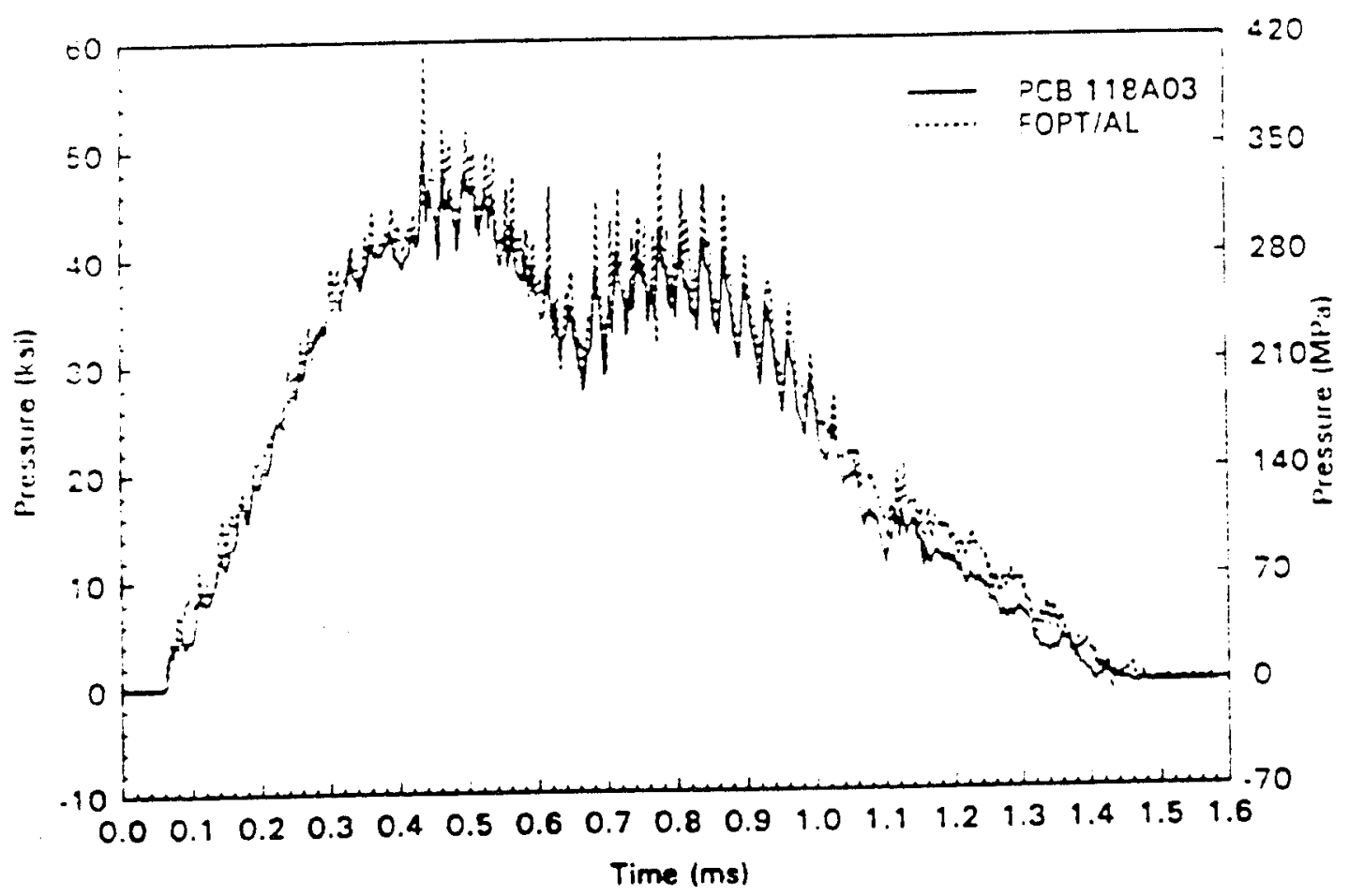

Figure 2. Comparison of the Pressure Pulse Measured Simultaneously with a PCB $118 \mathrm{AO} 3$ and an FOPTIAL - Peak pressure $\approx 350 \mathrm{MPa}(50 \mathrm{ksi})$ [Figure 16 in Liu et al., 1991].

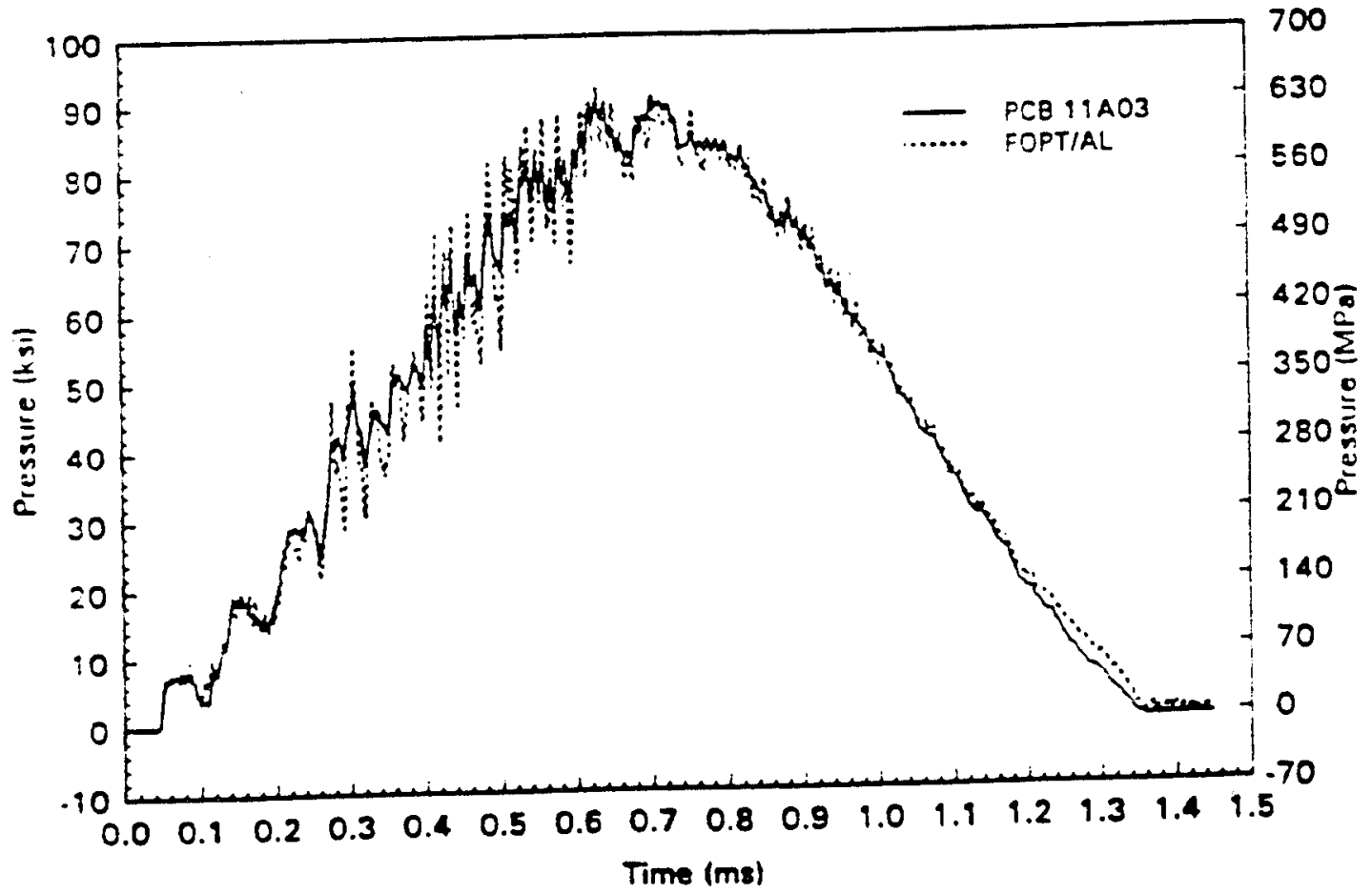

Figure 3. Comparison of the Pressure Pulse Measured Simultaneously with a PCB $118 \mathrm{A0} 3$ and an FOPTIAL - Peak pressure $\approx 630 \mathrm{MPa}(90 \mathrm{ksi})$ [Figure 17 in Lu et al., 1991]. 


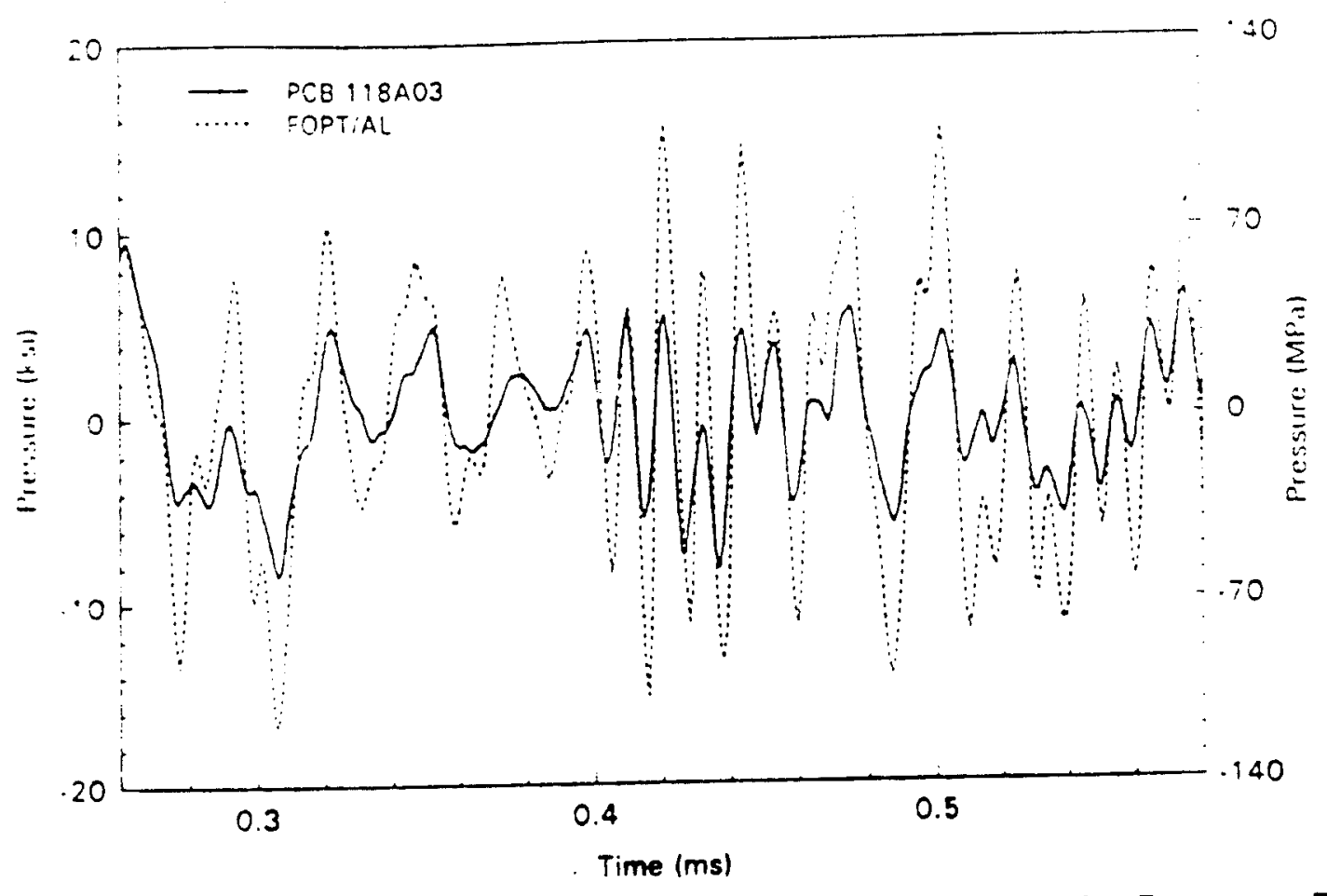

Figure 18. Comparison of the High-Harmonic Components of the Preseure Pulse Measured SImuttaneously with a PCB $118 A 03$ and an FOPT/AL. The time series are excerpted from Figure 17 with the linear trend removed.

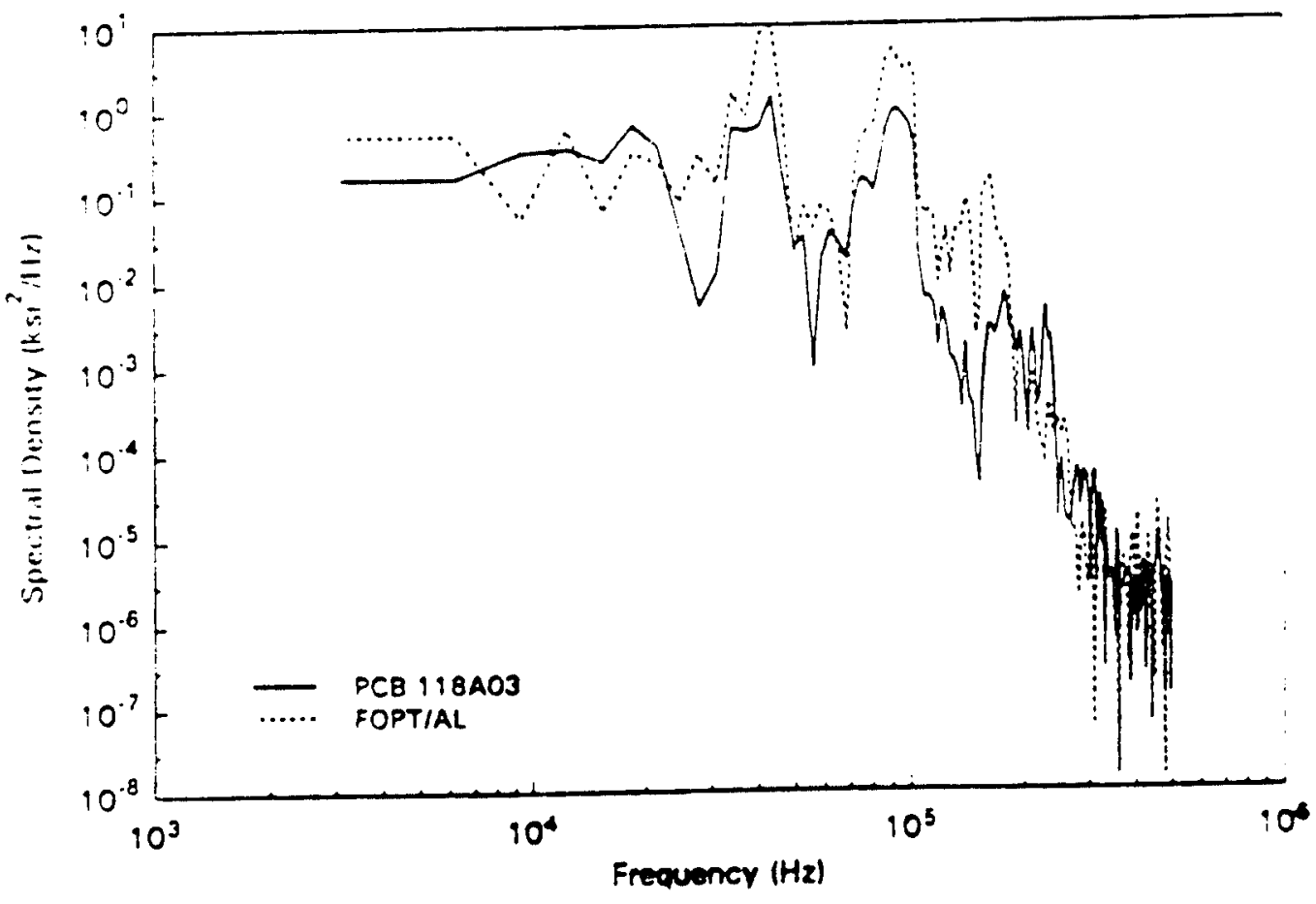

Figure 19. Comparison of the Power Spectra Derived from the Time Series Shown in Figure 18 


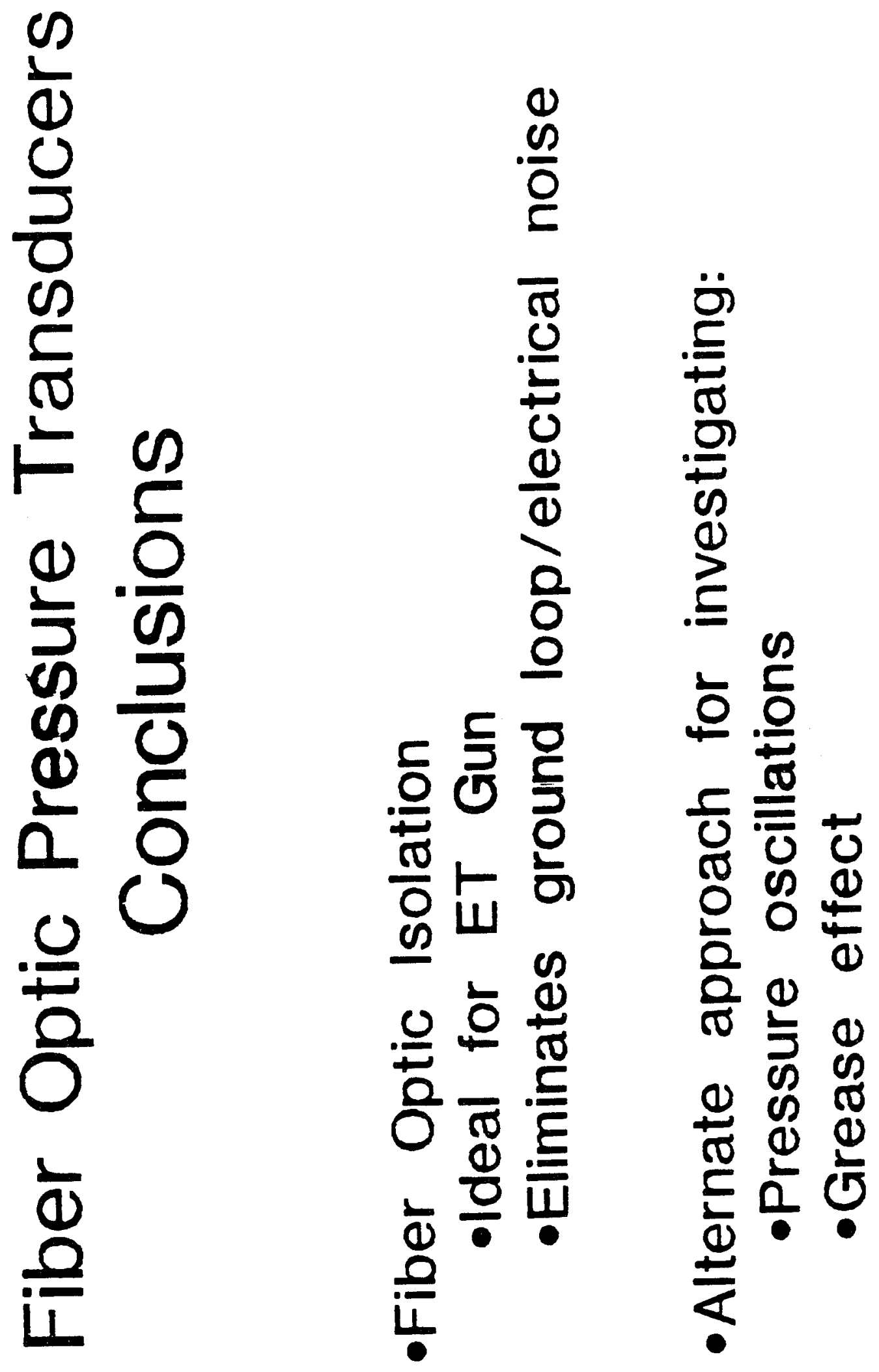


No. of

Copies Organization

2 Administrator

Defense Technical Info Center

ATTN: DTIC-DDA

Cameron Station

Alexandria, VA 22304-6145

1 Commander

U.S. Army Materiel Command

ATTN: AMCAM

5001 Eisenhower Ave.

Alexandria, VA 22333-0001

1 Director

U.S. Army Research Laboratory

ATTN: AMSRL-OP-SD-TA, 2800 Powder Mill Rd.

Records Management

Adelphi, MD 20783-1145

3 Director

U.S. Army Research Laboratory

ATTN: AMSRL-OP-SD-TL, Technical Library

2800 Powder Mill Rd.

Adelphi, MD 20783-1145

1 Director

U.S. Army Research Laboratory

ATTN: AMSRL-OP-SD-TP,

Technical Publishing Branch

2800 Powder Mill Rd.

Adelphi, MD 20783-1145

2 Commander

U.S. Army Armament Research,

Development, and Engineering Center

ATTN: SMCAR-TDC

Picatinny Arsenal, NJ 07806-5000

1 Director

Benet Weapons Laboratory

U.S. Army Armament Research,

Development, and Engineering Center

ATTN: SMCAR-CCB-TL

Watervliet, NY 12189-4050

1 Director

U.S. Army Advanced Systems Research and Analysis Office (ATCOM)

ATTN: AMSAT-R-NR, M/S 219-1

Ames Research Center

Moffett Field, CA 94035-1000
No. of

Copies Organization

1 Commander

U.S. Army Missile Command

ATTN: AMSMI-RD-CS-R (DOC)

Redstone Arsenal, AL 35898-5010

1 Commander

U.S. Army Tank-Automotive Command

ATTN: AMSTA-JSK (Armor Eng. Br.)

Warren, MI 48397-5000

1 Director

U.S. Army TRADOC Analysis Command

ATTN: ATRC-WSR

White Sands Missile Range, NM 88002-5502

1 Commandant

U.S. Army Infantry School

ATTN: ATSH-WCB-O

Fort Benning, GA 31905-5000

Aberdeen Proving Ground

2 Dir, USAMSAA

ATTN: AMXSY-D

AMXSY-MP, H. Cohen

1 Cdr, USATECOM

ATTN: AMSTE-TC

1 Dir, USAERDEC

ATTN: SCBRD-RT

1 Cdr, USACBDCOM

ATTN: AMSCB-CII

1 Dir, USARL

ATTN: AMSRL-SL-I

5 Dir, USARL

ATTN: AMSRL-OP-AP-L 
No. of

Copies Organization

1 Chairman

DOD Explosives Safety Board

Room 856-C

Hoffman Bldg. 1

2461 Eisenhower Avenue

Alexandria, VA 22331-0600

1 Headquarters

U.S. Army Materiel Command

ATTN: AMCICP-AD, M. Fisette

5001 Eisenhower Ave.

Alexandria, VA 22333-0001

1 U.S. Army Ballistic Missile

Defense Systems Command

Advanced Technology Center

P.O. Box 1500

Huntsville, AL 35807-3801

1 Department of the Army

Office of the Product Manager

155mm Howitzer, M109A6, Paladin

ATTN: SFAE-AR-HIP-IP, Mr. R. De Kleine

Picatinny Arsenal, NJ 07806-5000

3 Project Manager

Advanced Field Artillery System

ATTN: SFAE-ASM-AF-E,

LTC A. Ellis

T. Kuriata

J. Shields

Picatinny Arsenal, NJ 07801-5000

1 Project Manager

Advanced Field Artillery System

ATTN: SFAE-ASM-AF-Q, W. Warren

Picatinny Arsenal, NJ 07801-5000

1 Commander

Production Base Modernization Agency

U.S. Army Armament Research, Development, and Engineering Center

ATTN: AMSMC-PBM, A. Siklosi

Picatinny Arsenal, NJ 07806-5000

1 Commander

HQ AMCCOM

ATTN: AMSMC-SAS-WF, G. Schlenker

Rock Island, IL 61299-6000
No. of

Copies Organization

1 Commander

Production Base Modernization Agency

U.S. Army Armament Research, Development, and Engineering Center

ATTN: AMSMC-PBM-E, L. Laibson

Picatinny Arsenal, NJ 07806-5000

$1 \quad$ PEO-Armaments

Project Manager

Tank Main Armament System

ATTN: AMCPM-TMA

Picatinny Arsenal, NJ 07806-5000

1 PEO-Armaments

Project Manager

Tank Main Armament System

ATTN: AMCPM-TMA-105

Picatinny Arsenal, NJ 07806-5000

1 PEO-Armaments

Project Manager

Tank Main Armament System

ATTN: AMCPM-TMA-120

Picatinny Arsenal, NJ 07806-5000

1 PEO-Armaments

Project Manager

Tank Main Armament System

ATTN: AMCPM-TMA-AS, H. Yuen

Picatinny Arsenal, NJ 07806-5000

2 Commander

U.S. Army Armament Research, Development, and Engineering Center

ATTN: SMCAR-CCH-V, C. Mandala

E. Fennell

Picatinny Arsenal, NJ 07806-5000

1 Commander

U.S. Army Armament Research, Development, and Engineering Center

ATTN: SMCAR-CCH-T, L. Rosendorf

Picatinny Arsenal, NJ 07806-5000

1 Commander

U.S. Army Armament Research, Development, and Engineering Center

ATTN: SMCAR-CCS

Picatinny Arsenal, NJ 07806-5000 
No. of

Copies Organization

1 Commander

U.S. Army Armament Research, Development, and Engineering Center

ATTN: SMCAR-AEE, J. Lannon

Picatinny Arsenal, NJ 07806-5000

5 Commander

U.S. Army Armament Research, Development, and Engineering Center

ATTN: SMCAR-AEE-WW,

$M$. Mezger

J. Pinto

D. Wiegand

P. Lu

C. $\mathrm{Hu}$

Picatinny Arsenal, NJ 07806-5000

13 Commander

U.S. Army Armament Research, Development, and Engineering Center

ATTN: SMCAR-AEE-B,
A. Beardell
D. Chui
D. Downs
S. Einstein
R. King
S. Westley
S. Bernstein
J. Rutkowski
B. Brodman
P. O'Reilly
R. Cirincione
P. Hui
J. O'Reilly

Picatinny Arsenal, NJ 07806-5000

1 Commander

U.S. Army Armament Research, Development, and Engineering Center

ATTN: SMCAR-AES, S. Kaplowitz

Picatinny Arsenal, NJ 07806-5000

1 Commander

U.S. Army Armament Research, Development, and Engineering Center

ATTN: SMCAR-HFM, E. Barrieres

Picatinny Arsenal, NJ 07806-5000
No. of

Copies Organization

1 Commander

U.S. Army Armament Research, Development, and Engineering Center

ATTN: SMCAR-FSA-F, LTC R. Riddle

Picatinny Arsenal, NJ 07806-5000

1 Commander

U.S. Army Armament Research, Development, and Engineering Center

ATTN: SMCAR-FSC, G. Ferdinand

Picatinny Arsenal, NJ 07806-5000

1 Commander

U.S. Army Armament Research, Development, and Engineering Center

ATTN: SMCAR-FS, T. Gora

Picatinny Arsenal, NJ 07806-5000

2 Commander

U.S. Army Armament Research, Development, and Engineering Center

ATTN: SMCAR-FS-DH,

J. Feneck

D. Minchala

Picatinny Arsenal, NJ 07806-5000

4 Commander

U.S. Army Armament Research, Development, and Engineering Center

ATTN: SMCAR-FSS-A,

R. Kopmann

B. Machek

L. Pinder

C. Perazzo

Picatinny Arsenal, NJ 07806-5000

4 Commander

U.S. Army Armament Research, Development, and Engineering Center

ATTN: SMCAR-FSN-N,

K. Chung

A. Bahia

R. Lee

A. Readdy

Picatinny Arsenal, NJ 07806-5000 
No. of

Copies Organization

2 Commander

U.S. Army Research Office

ATTN: Technical Library, D. Mann

P.O. Box 12211

Research Triangle Park, NC 27709-2211

1 Commander, USACECOM

R\&D Technical Library

ATTN: ASQNC-ELC-IS-L-R, Myer Center

Fort Monmouth, NJ 07703-5301

1 Commandant

U.S. Army Aviation School

ATTN: Aviation Agency

Fort Rucker, AL 36360

1 Program Manager

U.S. Tank-Automotive Command

ATTN: AMCPM-ABMS, T. Dean

Warren, MI 48092-2498

1 Project Manager

U.S. Tank-Automotive Command

Fighting Vehicle Systems

ATTN: SFAE-ASM-BV

Warren, MI 48397-5000

1 Project Manager, Abrams Tank System

ATTN: SFAE-ASM-AB

Warren, MI 48397-5000

1 Director

HQ, TRAC RPD

ATTN: ATCD-MA

Fort Monroe, VA 23651-5143

1 Commander

U.S. Army Belvoir Research and

Development Center

ATTN: STRBE-WC

Fort Belvoir, VA 22060-5006

1 Director

U.S. Army TRAC-Ft. Lee

ATTN: ATRC-L, Mr. Cameron

Fort Lee, VA 23801-6140
No. of

Copies Organization

1 Commandant

U.S. Army Command and General Staff College

Fort Leavenworth, KS 66027

1 Commandant

U.S. Army Special Warfare School

ATTN: Rev and Trng Lit Div

Fort Bragg, NC 28307

1 Commander

Radford Army Ammunition Plant

ATTN: SMCAR-QA/HI LIB

Radford, VA 24141-0298

1 Commander

U.S. Army Foreign Science and Technology Center

ATTN: AMXST-MC-3

220 Seventh Street, NE

Charlottesville, VA 22901-5396

2 Commandant

U.S. Army Field Artillery Center and School

ATTN: ATSF-CO-MW, E. Dublisky ATSF-CN, P. Gross

Ft. Sill, OK 73503-5600

1 Commandant

U.S. Army Armor School

ATTN: ATZK-CD-MS, M. Falkovitch

Armor Agency

Fort Knox, KY 40121-5215

2 Commander

U.S. Army Yuma Proving Ground

ATTN: STEYP-RS-EL-B,

L. Hardin

K. Blue

Yuma, AZ 85365-9124

2 Commander

Naval Sea Systems Command

ATTN: SEA 62R

SEA 64

Washington, DC 20362-5101 
No. of

Copies Organization

1 Commander

Naval Air Systems Command

ATTN: AIR-954-Tech Library

Washington, DC 20360

4 Commander

Naval Research Laboratory

ATTN: Technical Library

Code 4410,

K. Kailasanate

J. Boris

E. Oran

Washington, DC 20375-5000

1 U.S. Army Research Development and Standardization Group (UK)

PSC 802 Box 15, Dr. Roy E. Richenbach

FPO AE 09499-1500

2 Office of Naval Research

ATTN: Code 473, R. S. Miller Code 332, G. Roy

800 N. Quincy Street

Arlington, VA 22217-9999

1 Office of Naval Technology

ATTN: ONT-213, D. Siegel

800 N. Quincy St.

Arlington, VA 22217-5000

2 Commander

Naval Surface Warfare Center

ATTN: Code 730

Code R-13, R. Bernecker

Silver Spring, MD 20903-5000

7 Commander

Naval Surface Warfare Center

ATTN: T. Smith

K. Rice

S. Mitchell

S. Peters

J. Consaga

C. Gotzmer

Technical Library

Indian Head, MD 20640-5000
No. of

Copies Organization

4 Commander

Naval Surface Warfare Center

ATTN: Code G30, Guns \& Munitions Div Code G32, Guns Systems Div Code G33, T. Doran Code E23, Technical Library

Dahlgren, VA 22448-5000

8 Commander

Naval Air Warfare Center

ATTN: Code 388 ,

C. Price

T. Boggs

Code 3895,

T. Parr

R. Derr

Information Science Division

Code 2391, M. Chan

Code 2392,

J. Finlinson

K. Schadow

China Lake, CA 93555-6001

1 Commanding Officer

Naval Underwater Systems Center

ATTN: Code 5B331, Technical Library

Newport, RI 02840

1 AFOSR/NA

ATTN: J. Tishkoff

Bolling AFB

Washington, DC 20332-6448

1 OLAC PL/TSTL

ATTN: D. Shiplett

Edwards AFB, CA 93523-5000

3 OL-AC PL/RK

ATTN: J. Levine

L. Quinn

T. Edwards

5 Pollux Drive

Edwards AFB, CA 93524-7048

1 WL/MNAA

ATTN: B. Simpson

Eglin AFB, FL 32542-5434 
No. of

Copies Organization

1 WL/MNME

Energetic Materials Branch

2306 Perimeter Rd.

STE 9

Eglin AFB, FL $32542-5910$

1 WL/MNSH

ATTN: R. Drabczuk

Eglin AFB, FL 32542-5434

2 NASA Langley Research Center

ATTN: M.S. 408,

W. Scallion

D. Witcofski

Hampton, VA 23605

1 Central Intelligence Agency

Office of Information Resources

Room GA-07 HQS

Washington, DC 20505

1 Central Intelligence Agency

ATTN: J. Backofen

NHB, Room 5N01

Washington, DC 20505

1 SDIO/TNI

ATTN: L. Caveny

Pentagon

Washington, DC 20301-7100

1 SDIO/DA

ATTN: E. Gerry

Pentagon

Washington, DC 21301-7100

2 HQ DNA

ATTN: D. Lewis
A. Fahey

6801 Telegraph Rd.

Alexandria, VA 22310-3398

1 Director

Sandia National Laboratories

Energetic Materials \& Fluid Mechanics

Department, 1512

ATTN: $M$. Baer

P.O. Box 5800

Albuquerque, NM 87185
No. of

Copies Organization

1 Director

Sandia National Laboratories

Combustion Research Facility

ATTN: R. Carling

Livermore, CA 94551-0469

2 Director

Sandia National Laboratories

ATTN: 8741, G. Beneditti 8152, R. Rychnovski

P.O. Box 969

Livermore, CA 94551-0969

2 Director

Lawrence Livermore National Laboratory

ATTN: L-355,

P.O. Box 808
A. Buckingham
M. Finger

Livermore, CA $94550-0622$

2 Director

Los Alamos Scientific Lab

ATTN: T3/D. Butler

M. Division/B. Craig

P.O. Box 1663

Los Alamos, NM 87544

1 Director

Los Alamos National Laboratories

ATTN: Donald Rabem

Los Alamos, NM 87545

2 Battelle

ATTN: TWSTIAC

V. Levin

505 King Avenue

Columbus, $\mathrm{OH}$ 43201-2693

1 Battelle PNL

ATTN: M. Bampton

P.O. Box 999

Richland, WA 99352

1 Textron Defense Systems

ATTN: A. Patrick

2385 Revere Beach Parkway

Everett, MA 02149-5900 
No. of

Copies Organization

1 General Applied Sciences Lab

ATTN: J. Erdos

77 Raynor Ave.

Ronkonkama, NY : 11779-6649

1 Institute of Gas Technology

ATTN: D. Gidaspow

3424 S. State Street

Chicago, IL 60616-3896

1 California State University

ATTN: Dr. F. Reardon

$6000 \mathrm{~J}$ Street

School of Engineering and Computer Science

Sacramento, CA 95819

1 Institute for Advanced Technology

ATTN: T. Kiehne

The University of Texas of Austin

4030-2 W. Braker Lane

Austin, TX 78759-5329

2 CPIA - JHU

ATTN: H. Hoffman

T. Christian

10630 Little Patuxent Parkway

Suite 202

Columbia, MD 21044-3200

1 Brigham Young University

Department of Chemical Engineering

ATTN: M. Beckstead

Provo, UT 84601

1 Jet Propulsion Laboratory

California Institute of Technology

ATTN: L. Strand, MS 125/224

4800 Oak Grove Drive

Pasadena, CA 91109

1 California Institute of Technology

204 Karman Lab

Main Stop 301-46

ATTN: F. Culick

1201 E. California Street

Pasadena, CA 91109
No. of

Copies Organization

3 Georgia Institute of Technology

School of Aerospace Engineering

ATTN: B. Zim

E. Price

W. Strahle

Atlanta, GA 30332

2 University of Illinois

Department of Mechanical/Industry Engineering

ATTN: H. Krier

R. Beddini

144 MEB; 1206 N. Green St.

Urbana, IL 61801-2978

1 University of Massachusetts

Department of Mechanical Engineering

ATTN: K. Jakus

Amherst, MA 01002-0014

1 University of Minnesota

Department of Mechanical Engineering

ATTN: E. Fletcher

Minneapolis, MN 55414-3368

3 Pennsylvania State University

Department of Mechanical Engineering

ATTN: V. Yang

K. Kuo

C. Merkle

University Park, PA 16802-7501

1 Rensselaer Polytechnic Institute

Department of Mathematics

Troy, NY 12181

1 Stevens Institute of Technology

Davidson Laboratory

ATTN: R. McAlevy III

Castle Point Station

Hoboken, NJ 07030-5907

1 Rutgers University

Department of Mechanical and

Aerospace Engineering

ATTN: S. Temkin

University Heights Campus

New Brunswick, NJ 08903 
No. of

$\underline{\text { Copies }}$ Organization

1 University of Utah

Department of Chemical Engineering

ATTN: A. Baer

Salt Lake City, UT 84112-1194

1 Washington State University

Department of Mechanical Engineering

ATTN: C. Crowe

Pullman, WA 99163-5201

2 University of Washington
ATTN:
A. Bruckner
C. Knowlen

FL-10

Seattle, WA 98195

2 Aerodyne Research, Inc.

ATTN: J. Wormhoudt

P. Kebabian

45 Manning Rd.

Billerica, MA 01821

1 AFELM, The Rand Corporation

ATTN: Library D

1700 Main Street

Santa Monica, CA 90401-3297

1 Arrow Technology Associates, Inc.

ATTN: W. Hathaway

P.O. Box 4218

South Burlington, VT 05401-0042

2 AAI Corporation

ATTN: J. Frankle

D. Cleveland

P.O. Box 126

Hunt Valley, MD 21030-0126

2 Alliant Techsystems, Inc.

ATTN: R. Tompkins

J. Kennedy

7225 Northland Dr.

Brooklyn Park, MN 55428

1 ECIII Corporation

ATTN: Welton Phillips

P.O. Box 6546

Yuma, AZ 85366
No. of

Copies Organization

$2 \quad$ United Defense Limited Partnership

Naval Systems Division

ATTN: Anthony Giovanetti

Mark Schneider

4800 East River Road

Minneapolis, MN 55421

8 Martin Marietta

Tactical System Department

ATTN: J. Mandzy

I. Magoon

P. Jordan

D. Cook

S. Brown

B. Haberl

R. Pate

W. Pasko

100 Plastics Ave.

Pittsfield, MA 01201-3698

1 IITRI

ATTN: $M$. Klein

$10 \mathrm{~W} .35$ th Street

Chicago, IL 60616-3799

2 Stone Engineering

ATTN: G. McKenzie

B. Iwanciow

805 Madison St., SE

Huntsville, AL 35801

1 PCB Piezotronics

ATTN: Ms. Marilyn Cooper

2738 W. Main St.

Alhambra, CA 91801

1 PCB Piezotronics

ATTN: Mr. D. Jaros

3425 Walden Ave.

Depew, NY 14043

2 Kistler Instrumentation Corporation

ATTN: John Kubler

Rich Cadille

75 John Glenn Drive

Amherst, NY 14228-2171 
No. of

Copies Organization

1 Endevco

ATTN: Mr. Jon Wilson

700 Rancho Viejo Rd.

San Juan Capistrano, CA 92675

4 Hercules, Inc.

Radford Army Ammunition Plant

ATTN: L. Gizzi

D. Worrell

W. Worrell

C. Chandler

Radford, VA 24141-0299

2 Hercules, Inc.

Allegheny Ballistics Laboratory

ATTN: William B. Walkup

Thomas F. Farabaugh

P.O. Box 210

Rocket Center, WV 26726

1 Hercules, Inc.

Aerospace

ATTN: R. Cartwright

100 Howard Blvd.

Kenville, NJ 07847

1 Hercules, Inc.

Hercules Plaza

ATTN: B. Riggleman

Wilmington, DE 19894

1 MBR Research Inc.

ATTN: Dr. Moshe Ben-Reuven

601 Ewing St., Suite C-22

Princeton, NJ 08540

1 Olin Corporation

Badger Army Ammunition Plant

ATTN: F. Wolf

Baraboo, WI 53913

3 Olin Ordnance

ATTN: E. Kirschke

A. Gonzalez

P.O. Box 222

D. Worthington

St. Marks, FL 32355-0222
No. of

Copies Organization

1 Olin Ordnance

ATTN: H. McElroy

10101 9th Street, North

St. Petersburg, FL 33716

1 Paul Gough Associates, Inc.

ATTN: P. Gough

1048 South St.

Portsmouth, NH 03801-5423

1 Physics International Library

ATTN: H. Wayne Wampler

P.O. Box 5010

San Leandro, CA 94577-0599

3 Princeton Combustion Research Laboratories, Inc.

ATTN: M. Summerfield

N. Mer

N. Messina

Princeton Corporate Plaza

11 Deerpark Dr., Bldg IV, Suite 119

Monmouth Junction, NJ 08852

3 Rockwell International

Rocketdyne Division

ATTN: BA05,

J. Flanagan

J. Gray

WC79, R. Edelman

6633 Canoga Avenue

Canoga Park, CA 91303-2703

2 Rockwell International Science Center

ATTN: Dr. S. Chakravarthy

Dr. S. Palaniswamy

1049 Camino Dos Rios

P.O. Box 1085

Thousand Oaks, CA 91360

1 Science Applications Intemational Corp.

ATTN: M. Palmer

2109 Air Park Rd.

Albuquerque, NM 87106

1 Southwest Research Institute

ATTN: J. Riegel

6220 Culebra Road

P.O. Drawer 28510

San Antonio, TX 78228-0510 
No. of

Copies Organization

1 Sverdrup Technology, Inc. ATTN: Dr. John Deur 2001 Aerospace Parkway Brook Park, OH 44142

3 Thiokol Corporation Elkton Division ATTN: R. Willer R. Biddle Tech Library

P.O. Box 241

Elkton, MD 21921-0241

2 Veritay Technology, Inc.

ATTN: E. Fisher

$$
\text { R. Talley }
$$

4845 Millersport Hwy.

East Amherst, NY 14501-0305

1 Universal Propulsion Company

ATTN: H. McSpadden

25401 North Central Ave.

Phoenix, AZ 85027-7837

1 SRI International

Propulsion Sciences Division

ATTN: Tech Library

333 Ravenwood Avenue

Menlo Park, CA 94025-3493

Aberdeen Proving Ground, MD

3 Cdr, USACSTA

ATTN: STECS-LI, R. Hendricksen STECS-DA-ID,

S. Walton

L. Francis

117 Dir, USARL

ATTN: AMSRL-WT-W, C. Murphy AMSRL-WT, D. Eccleshall AMSRL-WT-P,

A. Horst

J. Dante

AMSRL-WT-PC,

R. Fifer

G. Adams

W. Anderson

R. Beyer
No. of

Copies Organization

AMSRL-WT-PC (Continued),

S. Bunte

A. Cohen

B. Forch

A. Kotlar

J. Heimerl

M. Miller

A. Miziolek

M. Schroeder

J. Vanderhoff

AMSRL-WT-PB,

E. Schmidt

M. Bundy

D. Lyon

V. Oskay

P. Plostins

W. Thompson

AMSRL-WT-TA,

W. Gillich

M. Burkins

AMSRL-WT-TB,

R. Frey

L. Vande Kieft

N. Gniazdowski

AMSRL-WT-TC,

W. de Rossett

B. Sorensen

G. Silsby

AMSRL-WT-TD, A. Dietrich AMSRL-WT-WA,

H. Rogers

A. Baran

B. Moore

AMSRL-WT-WB,

W. D'Amico

F. Brandon

AMSRL-WT-PD,

B. Burns

A. Abrahamian (ALC)

K. Bannister

J. Bender

L. Burton

W. Drysdale

T. Erline

A. Frydman (ALC)

D. Hopkins

R. Kaste

L. Dean (ALC)

S. Wilkerson 
No. of

Copies Organization

Aberdeen Proving Ground, MD

Dir, USARL (Continued)

ATTN: AMSRL-WT-PA,

T. Minor

A. Birk

C. Bullock

T. Coffee

M. Del Guercio

J. DeSpirito

A. Johnson

A. Juhasz

G. Katulka

J. Knapton

C. Leveritt

M. McQuaid

W. Oberle

P. Reeves

M. Ridgley

I. Stobie

P. Tran

K. White

G. Wren

R. Anderson

A. Brant

L.-M. Chang

J. Colburn

P. Conroy

G. Gazonas

J. Hewitt

S. Howard

G. Keller

D. Kooker

A. Koszoru

D. Kruczynski

M. Leadore

R. Lieb

M. Nusca

B. Raley

F. Robbins

T. Rosenberger (6 cp)

C. Ruth

J. Tuerk

A. Williams

M. Kiwan

F. Liberatore
No. of

Copies Organization

AMSRL-WT-WC,

J. Rocchio

T. Brosseau

B. Haug

M. Kregel

AMSRL-WT-WD, A. Niiler

AMSRL-WT-WE,

J. Temperley

J. Thomas

AMSRL-WT-NC, J. Polk, Jr.

AMSRL-CI, W. Mermagen, Sr.

AMSRL-CI-A, H. Breaux

AMSRL-CI-AC, J. Grosh

AMSRI-CI-S, A. Mark

AMSRL-CI-C, W. Sturek

AMSRL-CI-CA, A. Celmins

AMSRL-CI-CC, B. Reichard

AMSRL-SL-I,

M. Starks

D. Haskell

AMSRL-SL-B, P. Deitz

AMSRL-SL-BG, D. Kirk

AMSRL-SL-BS, J. Jacobson

AMSRL-SL-BV, J. Smith 
INTENTIONALLY LEFT BLANK. 


\section{USER EVALUATION SHEET/CHANGE OF ADDRESS}

This Laboratory undertakes a continuing effort to improve the quality of the reports it publishes. Your comments/answers to the items/questions below will aid us in our efforts.

1. ARL Report Number ARL-SR-18

Date of Report _ September 1994

2. Date Report Received

3. Does this report satisfy a need? (Comment on purpose, related project, or other area of interest for which the report will be used.)

4. Specifically, how is the report being used? (Information source, design data, procedure, source of ideas, etc.)

5. Has the information in this report led to any quantitative savings as far as man-hours or dollars saved, operating costs avoided, or efficiencies achieved, etc? If so, please elaborate.

6. General Comments. What do you think should be changed to improve future reports? (Indicate changes to organization, technical content, format, etc.)

\section{Organization}

CURRENT

Name

ADDRESS

Street or P.O. Box No.

City, State, Zip Code

7. If indicating a Change of Address or Address Correction, please provide the Current or Correct address above and the Old or Incorrect address below.

\section{Organization}

OLD Name

ADDRESS

Street or P.O. Box No.

City, State, Zip Code

(Remove this sheet, fold as indicated, tape closed, and mail.)

(DO NOT STAPLE) 
OFFICIAL BUSINESS

NO POSTAGE NECESSARY

IF MAILED IN THE UNITED STATES
BUSINESS REPLY MAIL FIRST CLASS PERMIT NO 0001, APG, MD

Postage will be paid by addressee

Director

U.S. Army Research Laboratory

ATTN: AMSRL-OP-AP-L

Aberdeen Proving Ground, MD 21005-5066 